$$
\text { UNIVERSIDADE DE SÃO PAULO }
$$

FACULDADE DE MEDICINA VETERINÁRIA E ZOOTECNIA

\author{
ÍSIS ZANINI DAS CANDEIAS
}

Monitoramento não invasivo da ciclicidade ovariana em Lycalopex vetulus

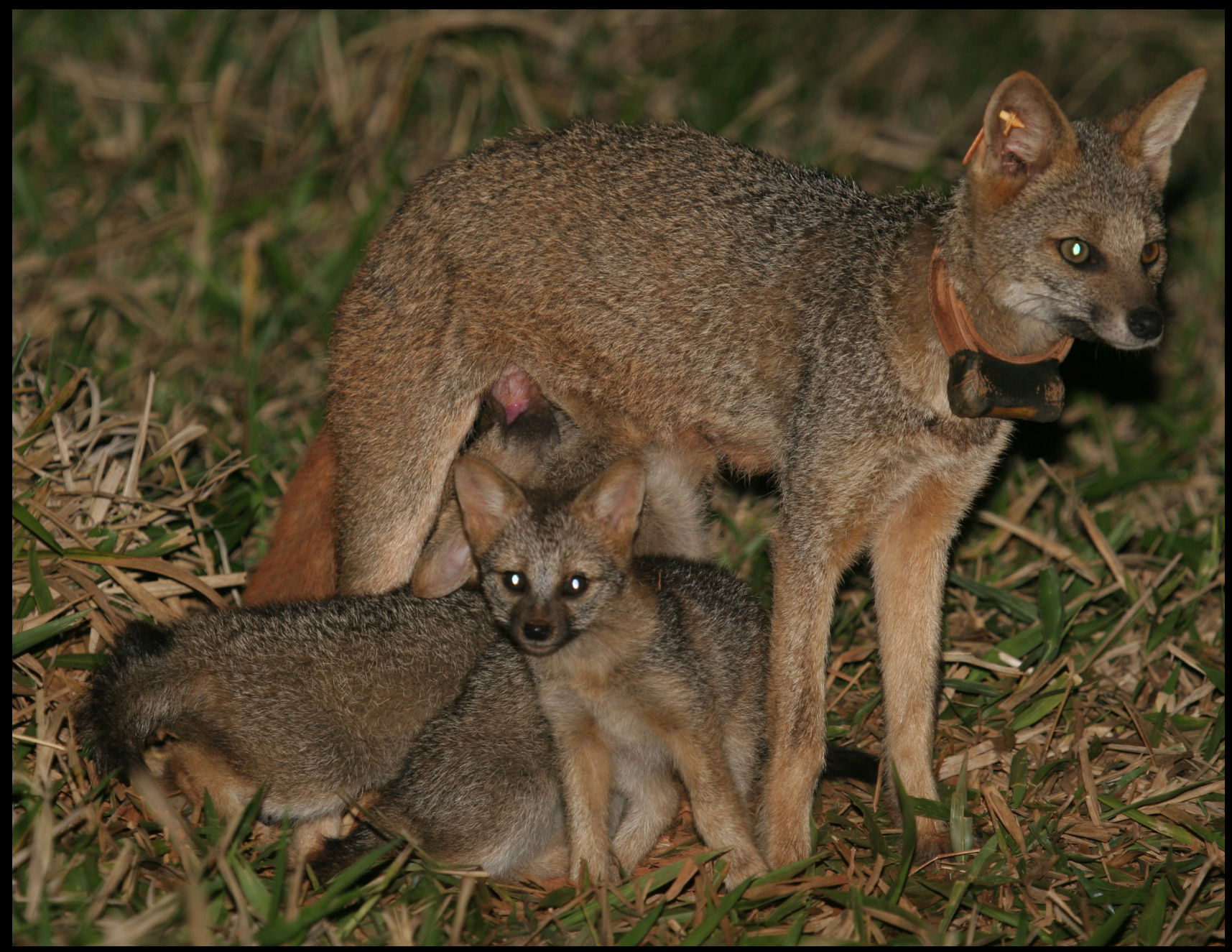

São Paulo 


\section{Monitoramento não invasivo da ciclicidade ovariana em Lycalopex vetulus}

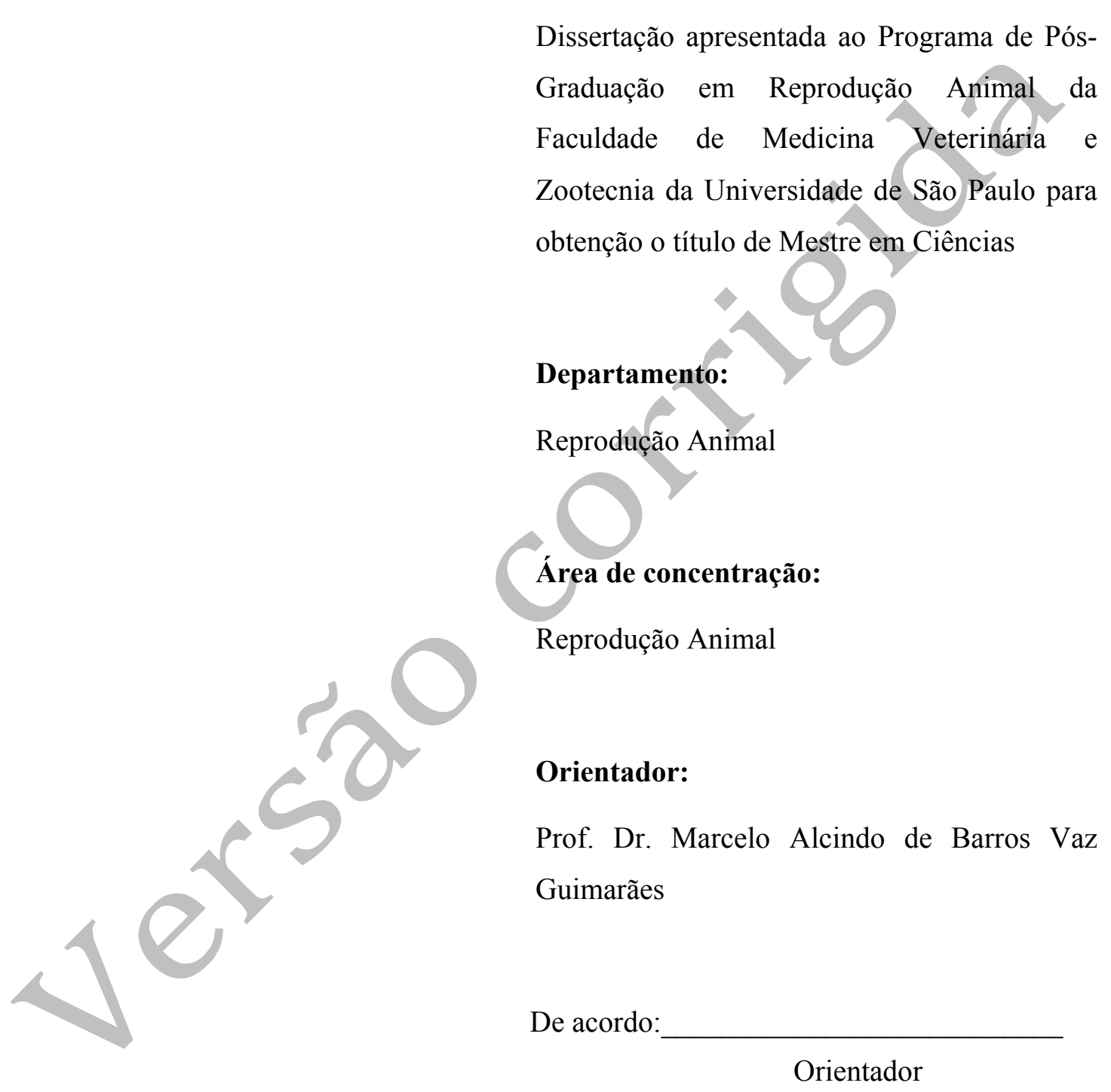

São Paulo

2014

Obs: A versão original se encontra disponível na Biblioteca da FMVZ/USP 
Autorizo a reprodução parcial ou total desta obra, para fins acadêmicos, desde que citada a fonte.

\section{DADOS INTERNACIONAIS DE CATALOGAÇÃO-NA-PUBLICAÇÃO}

(Biblioteca Virginie Buff D’Ápice da Faculdade de Medicina Veterinária e Zootecnia da Universidade de São Paulo)

\begin{tabular}{|c|c|}
\hline \multirow[t]{6}{*}{$\begin{array}{l}\text { T.3040 } \\
\text { FMVZ }\end{array}$} & $\begin{array}{l}\text { Candeias, Ísis Zanini das } \\
\text { Monitoramento não invasivo da ciclicidade ovariana em Lycalopex vetulus / Ísis Zanini das } \\
\text { Candeias. -- 2014. } \\
116 \text { f.: il. }\end{array}$ \\
\hline & $\begin{array}{l}\text { Dissertação (Mestrado) - Universidade de São Paulo. Faculdade de Medicina Veterinária e } \\
\text { Zootecnia. Departamento de Reprodução Animal, São Paulo, } 2014 .\end{array}$ \\
\hline & Programa de Pós-Graduação: Reprodução Animal. \\
\hline & Área de concentração: Reprodução Animal. \\
\hline & Orientador: Prof. Dr. Marcelo Alcindo de Barros Vaz Guimarães. \\
\hline & $\begin{array}{l}\text { 1. Lycalopex vetulus. 2. Ciclo reprodutivo. 3. Monitoramento não invasivo. 4. Endocrinologia } \\
\text { reprodutiva. 5. Hormônios. I. Título. }\end{array}$ \\
\hline
\end{tabular}




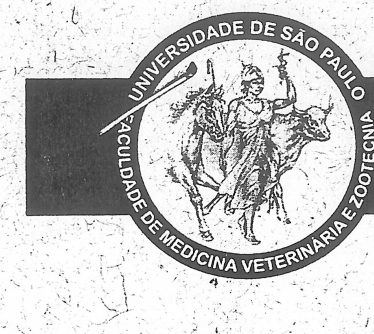

UNIVERSIDADE DE SÃO PAULO

\section{FACULDADE DE MEDICINA VETERINÁRIA E ZOOTECNIA}

\section{Comissão de Ética no uso de animais}

\section{CERTIFICADO}

Certificamos que o Projeto intitulado "Monitoramento hormonal não invasivo da ciclicidade ovariana em Lycalopex vetulus", protocolado sob o n $2714 / 2012$, utilizando 9 (nove) raposas do campo, sob a responsabilidade do(a) Prof. Dr. Marcelo Alcindo de Barros Vaz Guimarães, está de acordo com os princípios éticos de experimentação animal da "Comissão de Ética no uso de animais" da Faculdade de Medicina Veterinária e Zootecnia da Universidade de São Paulo e foi aprovado em reunião de 15/8/2012.

We certify that the Research "Non-invasive homonal monitoring of ovarian cyclicity in Lycalopex vetulus", protocol number 2714/2012, utilizing 9 (nine) Lycalopex vetulus, under the responsibility Prof. Dr. Marcelo-Alcindo de Barros Vaz Guimarães, agree with Ethical Principles in Animal Research adopted by "Ethic Committee in the use of animals" of the School of Veterinary Medicine and Animal Science of University of São Paulo and was approved in the meeting of day $8 / 15 / 2012$

São Paulo, 16 de agosto de 2012.

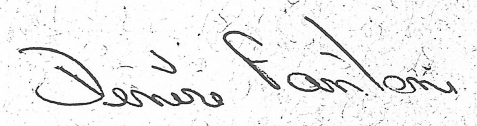

Denise Tabacchi Fantoni

Presidente 


\section{FOLHA DE AVALIAÇÃO}

Nome: CANDEIAS, Isis Zanini das

Título: Monitoramento não invasivo da ciclicidade ovariana em Lycalopex vetulus

Dissertação apresentada ao Programa de Pós-

Graduação em Reprodução Animal da

Faculdade de Medicina Veterinária e

Zootecnia da Universidade de São Paulo para

obtenção o título de Mestre em Ciências

Data:

Banca Examinadora

Prof. Dr. Instituição:

Assinatura: Julgamento:

Prof. Dr. Instituição:

Assinatura: Julgamento:

Prof. Dr. Instituição: Julgamento: 


\section{DEDICATÓRIA}

Aos meus pais, Elias e Lúcia que não só me proporcionaram a vida mas sempre me apoiaram em todas as minhas escolhas Sem seu apoio esse projeto não seria possivel. 


\section{AGRADECIMENTOS}

Ao meu professor e orientador Prof. Dr. Marcelo Alcindo de Barros Vaz Guimarães pela confiança no projeto, toda a orientação e ensinamentos.

A Dra. Nucharin Songsasen por todos os ensinamentos, treinamentos e ajuda com as dosagens hormonais no Instituto Smithsonian de Biologia da Conservação - SCBI.

Ao Caio por todo o incentivo, sempre, pelo apoio nos momentos difíceis e ajuda em todas as horas.

Ao meus pais, Elias e Lúcia, pela companhia nas longas viagens todos os meses, por todo o incentivo sempre que necessitei e apoio incondicional nas minhas escolhas.

Ao Rodrigo, Alexandra e Henrique do Zoológico de Sorocaba; a Michele do Zoológico de Americana; Marianna e Fabiana do Zoológico de Piracicaba; a Samanta do Zoológico de São Carlos; a Juliana e ao César do Zoológico de Ribeirão Preto; e a todos os demais técnicos que participaram e ajudaram na coleta de amostras.

Ao Eugênio, tratador do Zoológico de Sorocaba pelo excelente trabalho e dedicação aos animais.

Ao Frederico e a Fernanda por me proporcionar conhecer essa espécie especial e o Programa de Conservação Mamíferos do Cerrado, com o Projeto Raposinha do Campo.

Ao Marcilio, por toda ajuda e disponibilidade com as análises estatísticas.

A Fundação de Amparo a Pesquisa do Estado de São Paulo - FAPESP pelo auxílio a pesquisa que tornou possível a realização do presente estudo.

A Coordenação de Aperfeiçoamento de Pessoal de Nível Superior - CAPES pelo fornecimento da bolsa de auxilio. 
Muitas coisas são necessárias para mudar o mundo:

Raiva e tenacidade Ciência e indignação

A iniciativa rápida, a reflexão longa A paciencia fria e a infinita perseverança A compreensão do caso particular e compreensão do conjunto Apenas as lições da realidade podem nos ensinar como transformar a realidade 


\section{RESUMO}

CANDEIAS, I. Z. das. Monitoramento não invasivo da ciclicidade ovariana em Lycalopex vetulus. [Non-invasive monitoring of ovarian cyclicity in Lycalopex vetulus]. 2014. 113f. Dissertação (Mestrado em Ciências) - Faculdade de Medicina Veterinária e Zootecnia da Universidade de São Paulo, São Paulo, 2014.

Devido as atuais mudanças globais é esperado que um grande número de espécies necessitem de uma integração de ações dentro e fora do seu ambiente natural para a conservação. O bioma cerrado é um dos ecossistemas mais ricos em biodiversidade, mas devido a ação antrópica, resta menos de $20 \%$ de sua cobertura vegetal original. A Raposinha do Campo (Lycalopex vetulus) é um canídeo de pequeno porte (2,5-4kg) endêmico do cerrado do Brasil central e está presente na lista dos animais ameaçados de extinção do Estado de São Paulo. Não existe em literatura uma descrição detalhada do ciclo estral desta espécie. O presente estudo teve como objetivo caracterizar a ciclicidade ovariana de Lycalopex vetulus com o uso de método não-invasivo: Extração e mensuração de metabólitos fecais de progesterona e estradiol, com o uso da técnica de enzimaimunoensaio, verificando também a possível existência de diferenças mensais entre as médias das concentrações dos referidos metabólitos em um período de 12 meses. Foram utilizadas 8 fêmeas, adultas, presentes em cinco instituições no estado de São Paulo, onde foram coletadas fezes 3 vezes por semana de cada indivíduo, durante 12 meses, para a extração e mensuração dos metabólitos de progesterona, estradiol e corticosterona. Os perfis das excreções dos metabólitos fecais dos hormônios sexuais de 6 das 8 fêmeas, foram muito semelhantes, sendo período de maior atividade reprodutiva entre os messes de julho, agosto e setembro, ocorrendo mais de um ciclo ovulatório dentro desse período. Nos outros meses do ano, apesar de algumas variações acima da linha basal, não foram encontrados indícios de atividade reprodutiva. De acordo com essas características, semelhante entre a maioria das fêmeas do estudo, podemos sugerir que a raposa-do-campo seja poliestrica sazonal, com atividade reprodutiva ocorrendo nos meses de julho, agosto e setembro. Esses achados são muito próximos do visualizado em populações de vida livre, onde acasalamentos são observados entre junho e julho. O perfil de excreção dos metabólitos fecais de glicocorticóides segue o mesmo padrão observado para os metabólitos de progesterona e estradiol, com um aumento mais significativo da excreção nos meses de julho, agosto e setembro. Esses resultados indicam que além da grande quantidade de estressores que podem alterar a excreção de glicocorticóides, também deve-se considerar a 
flutuação sazonal e o status reprodutivo do indivíduo ao avaliar as concentrações de metabólitos de glicocorticóides. Duas fêmeas, que dividem o mesmo recinto, não apresentaram um padrão de ciclicidade reprodutiva. Os resultados obtidos nesse estudo indicam que a dosagem de metabólitos fecais de progesterona e estradiol podem ser usadas para diferenciar o período reprodutivo do período não reprodutivo em fêmeas de Lycalopex vetulus, fornecendo informações importantes sobre a biologia reprodutiva da espécie, o que pode contribuir no desenvolvimento de estratégias para a conservação desta espécie, como por exemplo aumentar o sucesso reprodutivo ex situ.

Palavras-chave: Lycalopex vetulus. Ciclo reprodutivo. Monitoramento não invasivo. Endocrinologia reprodutiva. Hormônios. 


\begin{abstract}
CANDEIAS, I. Z. das. Non-invasive monitoring of ovarian cyclicity in Lycalopex vetulus. [Monitoramento não invasivo da ciclicidade ovariana de Lycalopex vetulus]. 2014. 113f. Dissertação (Mestrado em Ciências) - Faculdade de Medicina Veterinária e Zootecnia da Universidade de São Paulo, São Paulo, 2014.
\end{abstract}

Due to the current global changes is expected that a large number of species require an integration of actions inside and outside their natural environment for them conservation. The cerrado is one of the richest ecosystems in biodiversity, but due to human action, there remains less than $20 \%$ of its original vegetation cover. The Hoary fox (Lycalopex vetulus $)$ is a small canid $(2,5-4 \mathrm{~kg})$ endemic of the cerrado from the central Brazil and is present in the list of endangered species in the state of São Paulo. It was not found in literature any detailed description of the estrous cycle of this species. The present study aimed to characterize ovarian cyclicity in Lycalopex vetulus using a noninvasive method: Extraction and measurement of fecal metabolites of estradiol and progesterone, using the technique of enzymeimmunoassay, It was also verified the possible differences between the monthly mean concentrations of these metabolites in a period of 12 months. 8 captive adult females, were studied in five different institutions in the state of São Paulo, where feces were collected three times per week for each individual for 12 months for extraction and measurement of metabolites of progesterone, estradiol and glucocorticoids. The profile of the concentration of fecal metabolites of sexual hormones from 6 of 8 females was very similar, being the period of major reproductive activity between the months of July, August and September, with the occurrence of more than one ovulatory cycle within that period. In the others months of the year, despite some variations above the baseline, no evidence of reproductive activity were found. According to these characteristics, similar in most females of the study, we can suggest that the hoary fox is seasonal polyestrous with reproductive activity occurring in the months of July, August and September. These findings are very close to the observed in wild populations, where mating is observed between June and July. The profile of excretion of fecal glucocorticoid metabolites follows the same pattern observed for the metabolites of progesterone and estradiol, with a more significant increase in excretion in the months of July, August and September. These results indicate that besides the large amount of stressors that can alter the excretion of glucocorticoids also it must be considered the seasonal fluctuation and the reproductive status of the individual to 
evaluate the levels of glucocorticoids. Two females, who share the same captivity, did not show a pattern of reproductive cyclicity. The results of this study indicate that the dosage of fecal metabolites of estradiol and progesterone can be used to differentiate the reproductive period of non-reproductive period in females of Lycalopex vetulus, providing important information about the reproductive biology, which may contribute to the development of the species conservation strategies, such as increasing the reproductive ex situ success.

Keywords: Lycalopex vetulus. Reproductive cycle. Noninvasive monitoring. Reproductive Endocrinology. Hormones. 


\section{LISTA DE FIGURAS}

Figura 1 - Lobo Guará (Chrysocyon brachyurus) 28

Figura 2 - Cachorro Vinagre (Speothos venaticus) 28

Figura 3 - Cachorro-do-Mato (Cerdocyon thous) 29

Figura 4 - Raposa-do-Campo (Lycalopex vetulus) 30

Figura 5 - Filhotes de L. vetulus 31

Figura 6 - Esquema das mudanças típicas nas concentrações 33 circulantes dos hormônios reprodutivos no ciclo estral da cadela doméstica não prenhe

Figura 7 - Cascata de Hormônios derivados do Colesterol $\quad 34$

Figura 8 - Esquema: Componentes do Comportamento 36

Figura 9 - Fêmea de L. vetulus (Fêmea 1) do Parque Ecológico de 46 Americana

Figura 10 - Ilustração do recinto das L. vetulus no Parque Ecológico de 47 Americana

Figura 11 - Fêmea de L. vetulus (Fêmea 2) no Zoológico de Piracicaba 48

Figura 12 - Fêmea de L. vetulus (Fêmea 3) no Zoológico de Piracicaba 48

Figura 13 - Ilustração do recinto das L. vetulus no Zoológico de 49 Piracicaba

Figura 14 - Ilustração do recinto das L. vetulus no Parque Ecológico de 50 São Carlos

Figura 15 - Fêmea de L. vetulus (Fêmea 4) no Parque Ecológico de São 51 Carlos - Dr. Antônio Teixeira Vianna

Figura 16 - Fêmea de L. vetulus (Fêmea 5) do Parque Zoológico 52 Municipal Quinzinho de Barros

Figura 17 - Fêmea de L. vetulus (Fêmea 6) do Parque Zoológico 52 Municipal Quinzinho de Barros

Figura 18 - Ilustração do recinto das L. vetulus no Parque Zoológico 53 Municipal Quinzinho de Barros

Figura 19 - Fêmea de L. vetulus (Fêmea 7) no Bosque e Zoológico Municipal Dr. Fábio de Sá Barreto

Figura 20 - Fêmea de L. vetulus (Fêmea 8) no Bosque e Zoológico Municipal Dr. Fábio de Sá Barreto

Figura 21 - Ilustração do recinto das L. vetulus no Bosque e Zoológico Municipal Dr. Fábio de Sá Barreto

Figura 22 - Material entregue as instituições para a coleta de amostras 56

Figura 23 - Equipamentos utilizados na extração das amostras fecais no 58 Laboratório de Dosagens Hormonais da Faculdade de 
Medicina Veterinária e Zootecnia da Universidade de São Paulo

Figura 24 - Leitora óptima MRX utilizada na leitura das placas (Dynex MRX; Dynex Technologies, VA)

Figura 25 - Mapa das Microplacas utilizado nos enzimaimunoensaios $\quad 60$

Figura 26 - Microplacas de enzimaimunoensaio em diferentes estágios 61 de desenvolvimento

Figura 27 - Ilustração da filtragem da amostra previamente ao processo 64 de HPLC

Figura 28 - Equipamento de HPLC (Varian ProStar, Varian Analytical 65 Instuments, Lexington, Massachusetts)

Figura 29 - Contador de Radioatividade utilizado no teste após a 66 separação de alíquotas no HPLC 


\section{LISTA DE GRÁFICOS}

Gráfico 1 - Validação Fisiológica da Fêmea 2

Gráfico 2 - Validação Fisiológica da Fêmea $3 \quad 71$

Gráfico 3 - Validação Fisiológica da Fêmea 5

Gráfico 4 - Validação Fisiológica da Fêmea $6 \quad 72$

Gráfico 5 - Relação de Paralelismo para ensaio de Progesterona 73

Gráfico 6 - Relação de Paralelismo para ensaio de Conjugado de 73 Estrona

Gráfico 7 - Relação de Paralelismo para ensaio de Corticosterona 73

Gráfico 8 - Teste de Acurácia para ensaio de Progesterona 74

Gráfico 9 - Teste de Acurácia para ensaio de Conjugado de Estrona $\quad 74$

Gráfico 10 - Teste de Acurácia para ensaio de Corticosterona 75

Gráfico 11 - Resultado do HPLC para Metabólitos fecais de Estradiol 76

Gráfico 12 - Resultado do HPLC para Metabólitos fecais de 76 Progesterona

Gráfico 13 - Dosagem dos metabólitos fecais de Progesterona para a $\quad 77$ Fêmea 1

Gráfico 14 - Dosagem dos metabólitos fecais de Progesterona para a $\quad 77$ Fêmea 2

Gráfico 15 - Dosagem dos metabólitos fecais de Progesterona para a 78 Fêmea 3

Gráfico 16 - Dosagem dos metabólitos fecais de Progesterona para a 78 Fêmea 4

Gráfico 17 - Dosagem dos metabólitos fecais de Progesterona para a $\quad 79$ Fêmea 5

Gráfico 18 - Dosagem dos metabólitos fecais de Progesterona para a $\quad 79$ Fêmea 6

Gráfico 19 - Dosagem dos metabólitos fecais de Progesterona para a $\quad 80$ Fêmea 7

Gráfico 20 - Dosagem dos metabólitos fecais de Progesterona para a $\quad 80$ Fêmea 8

Gráfico 21 - Dosagem dos metabólitos fecais de Estradiol para a Fêmea 81 1

Gráfico 22 - Dosagem dos metabólitos fecais de Estradiol para a Fêmea 81 2

Gráfico 23 - Dosagem dos metabólitos fecais de Estradiol para a Fêmea 82 3 
Gráfico 24 - Dosagem dos metabólitos fecais de Estradiol para a Fêmea 82 4

Gráfico 25 - Dosagem dos metabólitos fecais de Estradiol para a Fêmea 83 5

Gráfico 26 - Dosagem dos metabólitos fecais de Estradiol para a Fêmea 83 6

Gráfico 27 - Dosagem dos metabólitos fecais de Estradiol para a Fêmea 84 7

Gráfico 28 - Dosagem dos metabólitos fecais de Estradiol para a Fêmea 84 8

Gráfico 29 - Dosagem dos metabólitos fecais de Progesterona e 85 Estradiol para a Fêmea 1

Gráfico 30 - Dosagem dos metabólitos fecais de Glicocorticóides para a 85 Fêmea 1

Gráfico 31 - Dosagem dos metabólitos fecais de Progesterona e 86 Estradiol para a Fêmea 2

Gráfico 32 - Dosagem dos metabólitos fecais de Glicocorticóides para a 86 Fêmea 2

Gráfico 33 - Dosagem dos metabólitos fecais de Progesterona e 87 Estradiol para a Fêmea 3

Gráfico 34 - Dosagem dos metabólitos fecais de Glicocorticóides para a 87 Fêmea 3

Gráfico 35 - Dosagem dos metabólitos fecais de Progesterona e $\quad 88$ Estradiol para a Fêmea 4

Gráfico 36 - Dosagem dos metabólitos fecais de Glicocorticóides para a 88 Fêmea 4

Gráfico 37 - Dosagem dos metabólitos fecais de Progesterona e $\quad 89$ Estradiol para a Fêmea 5

Gráfico 38 - Dosagem dos metabólitos fecais de Glicocorticóides para a 89 Fêmea 5

Gráfico 39 - Dosagem dos metabólitos fecais de Progesterona e $\quad 90$ Estradiol para a Fêmea 6

Gráfico 40 - Dosagem dos metabólitos fecais de Glicocorticóides para a 90 Fêmea 6

Gráfico 41 - Dosagem dos metabólitos fecais de Progesterona e 91 Estradiol para a Fêmea 7

Gráfico 42 - Dosagem dos metabólitos fecais de Glicocorticóides para a 91 Fêmea 7

Gráfico 43 - Dosagem dos metabólitos fecais de Progesterona e 92 Estradiol para a Fêmea 8

Gráfico 44 - Dosagem dos metabólitos fecais de Glicocorticóides para a 92 
Fêmea 8

Gráfico 45 - Média mensal dos metabólitos fecais de Progesterona para 93 a Fêmea 1

Gráfico 46 - Média mensal dos metabólitos fecais de Estradiol para a Fêmea 1

Gráfico 47 - Média mensal dos metabólitos fecais de Progesterona para a Fêmea 2

Gráfico 48 - Média mensal dos metabólitos fecais de Estradiol para a Fêmea 2

Gráfico 49 - Média mensal dos metabólitos fecais de Progesterona para a Fêmea 3

Gráfico 50 - Média mensal dos metabólitos fecais de Estradiol para a Fêmea 3

Gráfico 51 - Média mensal dos metabólitos fecais de Progesterona para 94 a Fêmea 4

Gráfico 52 - Média mensal dos metabólitos fecais de Estradiol para a 94 Fêmea 4

Gráfico 53 - Média mensal dos metabólitos fecais de Progesterona para 94 a Fêmea 5

Gráfico 54 - Média mensal dos metabólitos fecais de Estradiol para a 94 Fêmea 5

Gráfico 55 - Média mensal dos metabólitos fecais de Progesterona para 95 a Fêmea 6

Gráfico 56 - Média mensal dos metabólitos fecais de Estradiol para a 95 Fêmea 6

Gráfico 57 - Média mensal dos metabólitos fecais de Progesterona para 95 a Fêmea 7

Gráfico 58 - Média mensal dos metabólitos fecais de Estradiol para a 95 Fêmea 7

Gráfico 59 - Média mensal dos metabólitos fecais de Progesterona para 95 a Fêmea 8

Gráfico 60 - Média mensal dos metabólitos fecais de Estradiol para a 95 Fêmea 8

Gráfico 61 - Média mensal dos metabólitos fecais de Estradiol para as 96 fêmeas cíclicas (Fêmeas 1, 2, 3, 4, 5 e 6)

Gráfico 62 - Média mensal dos metabólitos fecais de Progesterona para 96 as fêmeas cíclicas (Fêmeas 1, 2, 3, 4, 5 e 6)

Gráfico 63 - Média mensal dos metabólitos fecais de Glicocorticóides 96 para as fêmeas cíclicas (Fêmeas 1, 2, 3, 4, 5 e 6) 


\section{LISTA DE TABELAS}

Tabela 1 - Distribuição dos animais participantes do estudo nas instituições, identificação de cada indivíduo, idade aproximada e histórico de reprodução, 2014

Tabela 2 - Composição da dieta oferecida aos L. vetulus no Parque Ecológico de Americana

Tabela 3 - Composição da dieta oferecida aos L. vetulus no Zoológico

49 de Piracicaba

Tabela 4 - Composição da dieta oferecida aos L. vetulus no Parque Ecológico de São Carlos

Tabela 5 - Composição da dieta oferecida aos L. vetulus no Parque Zoológico Municipal Quinzinho de Barros pela manhã

Tabela 6 - Exemplo do Cálculo de DPM final por fração

Tabela 7 - Número de amostras de fezes coletadas mensalmente de cada indivíduo 


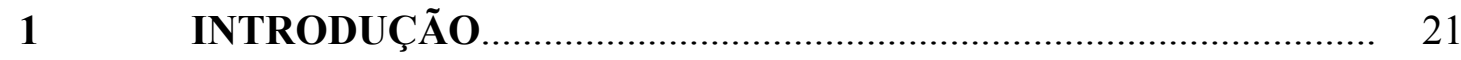

2 REVISÃO DE LITERATURA …………………………………... 24

2.1 CONSERVAÇÃO DA BIODIVERSIDADE........................................... 24

2.2 PAPEL DO ZOOLÓGICOS NA CONSERVAÇÃO................................ 25

2.3 CARNÍVOROS.................................................................................. 26

2.4 CANÍDEOS BRASILEIROS........................................................... 27

$2.5 \quad$ RAPOSINHA DO CAMPO........................................................... 29

$2.6 \quad$ FISIOLOGIA REPRODUTIVA....................................................... 32

2.7 HORMÔNIOS GLICOCORTICÓIDES.................................................. 35

$2.8 \quad$ ENDOCRINOLOGIA COMPORTAMENTAL_..................................... 36

2.9 RITMOS BIOLÓGICOS.................................................................. 37

2.10 DOSAGEM HORMONAL NÃO INVASIVA...................................... 38

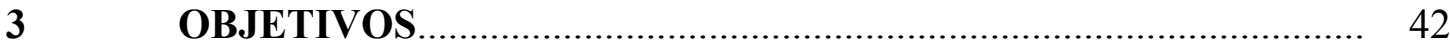

4 MATERIAIS E MÉTODOS........................................................... 44

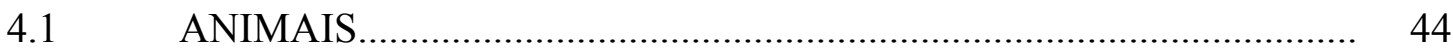

4.1.1 Parque Ecológico de Americana - Americana -SP ........................... 45

4.1.2 Zoológico de Piracicaba - Piracicaba - SP........................................ 48

4.1.3 Parque Ecológico São Carlos - Dr. Antônio Teixeira Vianna - São 50 Carlos - SP ............................................................................

4.1.4 Parque Zoológico Municipal Quinzinho de Barros. - Sorocaba - 51 SP..................................................................................

4.1.5 Bosque e Zoológico Municipal Dr. Fábio de Sá Barreto - Ribeirão 54 Preto-SP.

4.2 COLETA DAS AMOSTRAS........................................................ 55

4.3 VALIDAÇÃO BIOLÓGICA DOS MÉTODOS...................................... 57

4.4 EXTRAÇÃO DOS METABÓLITOS.................................................... 57

4.5 DOSAGEM POR ENZIMAIMUNOENSAIO_....................................... 59

4.6 PARALELISMO......................................................................... 61

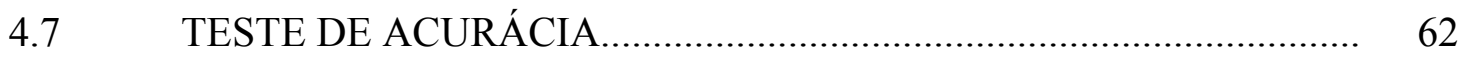

4.8 HPLC- CROMATOGRAFIA LÍQUIDA DE ALTA PERFORMANCE 62

4.8.1 Protocolo de HPLC - Preparação da Amostra ..................................... 63

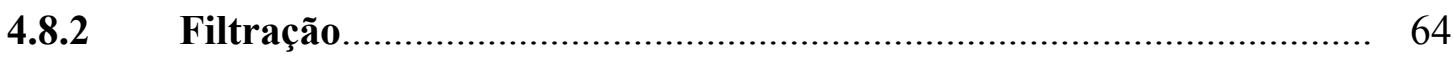

4.8.3 Adicionando Marcador Radioativo na Amostra................................... 65 


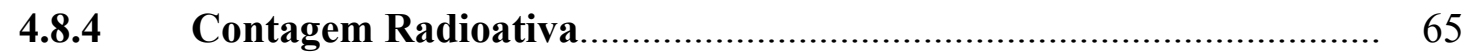

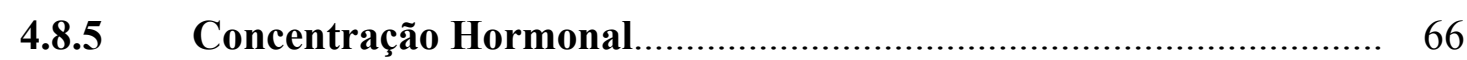

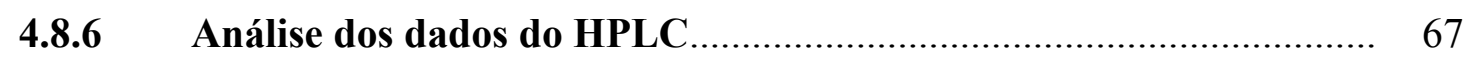

4.9 ANÁLISE ESTATÍSTICA.......................................................... 67

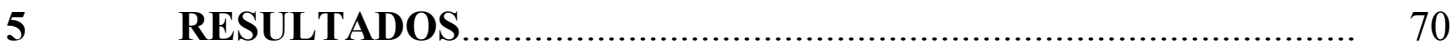

5.1 VALIDAÇÃO FISIOLÓGICA...................................................... 70

5.2 TESTE DE PARALELISMO_.......................................................... 73

5.3 TESTE DE ACURÁCIA.............................................................. 74

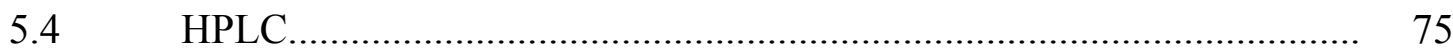

5.5 DOSAGEM DOS METABÓLITOS FECAIS DE PROGESTERONA.. 77

5.6 DOSAGEM DOS METABÓLITOS FECAIS DE ESTRADIOL........... 81

5.7 DOSAGEM DOS METABÓLITOS FECAIS DE PROGESTERONA, 85

5.8 MÉDIAS MENSAIS HORMONAIS ............................................... 93

$6 \quad$ DISCUSSÃO

6.1 VALIDAÇÃO FISIOLÓGICA DA TÉCNICA..................................... 98

6.2 PERFIL DA EXCREÇÃO HORMONAL DOS METABÓLITOS FECAIS DE PROGESTERONA, ESTRADIOL E 98

GLICOCORTICÓIDES.

6.2.1 Concentrações de Progesterona e Estradiol..................................... 98

6.2.2 Concentrações de Glicocorticóides.................................................. 101

ESTUDOS FUTUROS............................................................... 104

6.4 COMENTÁRIOS FINAIS ............................................................. 105

6.4.1 Recintos e Alimentação da Raposa-do-campo em Cativeiro.............. 105

6.4.2 Conservação de Espécies e o Papel dos Zoológicos............................. 106

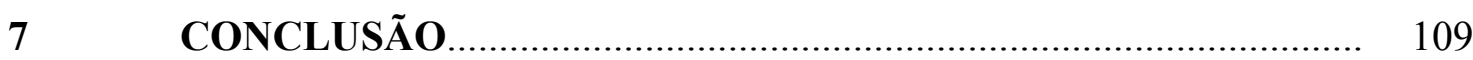

REFERÊNCIAS ............................................................. 111 


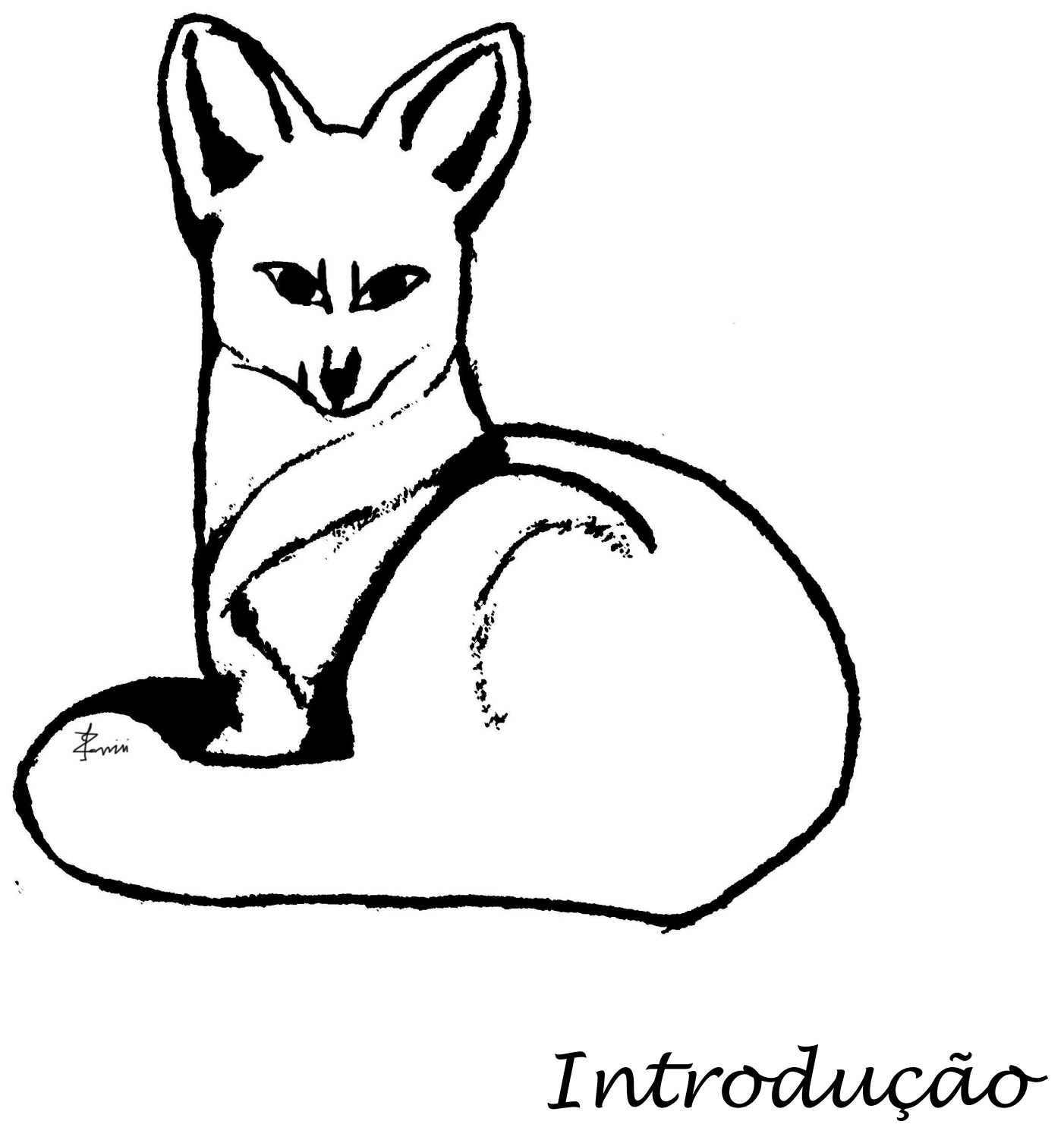




\section{INTRODUÇÃ O}

A cada ano, cresce o número de espécies avaliadas pela IUCN (União Internacional para a Conservação da Natureza), e consequentemente cresce também o número de espécies ameaçadas de extinção (IUCN, 2014). É fundamental fornecermos a maior quantidade de informações possíveis sobre as nossas espécies, para que elas possam ser adequadamente avaliadas e manejadas de acordo com a necessidade.

As mudanças globais representam um desafio sem precedente para a manutenção da biodiversidade. É esperado que mesmo sob o mais otimista cenário de impacto e adaptação um grande número de espécies não possa mais apenas ser mantido unicamente em seu habitat natural. Eles podem necessitar de uma integração das ações para a conservação, incluindo os Conservation breeding Programs- CBPs (Programas de Reprodução para a Conservação). Esta integração envolve tanto ações de conservação e gerenciamento dos habitats naturais, quanto manutenção, reprodução e pesquisa em zoológicos e outras instituições que mantenham os animais fora de seu habitat natural, para que possam ser desenvolvidas melhores estratégias e ações para a conservação da biodiversidade (CONDE et al., 2011a). Para isso precisamos ter planejamento e pesquisa a fim de ter o maior número de informações possíveis sobre nossas espécies.

A raposa-do-campo (Lycalopex vetulus) é um canídeo de pequeno porte $(2,5-4 \mathrm{~kg})$, endêmico de áreas abertas de Cerrado do Brasil Central (DALPONTE, 1995; DALPONTE; COURTENAY, 2004; JÁCOMO et al., 2004). Apesar de existirem alguns poucos trabalhos acerca de sua dieta e área de vida (JUAREZ; MARINHO-FILHO, 2002; DALPONTE, 2003; COURTENAY et al., 2006; ROCHA, 2006; LEMOS, 2007; LEMOS; FACURE, 2011) muito pouco é conhecido sobre sua ecologia e fisiologia, não existindo nenhum trabalho a cerca de sua fisiologia reprodutiva. No estado de São Paulo a raposinha é classificada como animal ameaçado de extinção (SÃO PAULO, 2014).

Os indivíduos de L. vetulus se organizam em pares monogâmicos durante o estágio reprodutivo e em grupos familiares durante a criação dos filhotes e parte do período prédispersão (DALPONTE, 2003). O período reprodutivo dessa espécie é marcadamente sazonal, com nascimentos ocorrendo uma vez ao ano, após uma gestação de aproximadamente 50 dias, caracterizando um padrão monoéstrico para a espécie (DALPONTE, 2003). 
Métodos alternativos de pesquisa em fisiologia da reprodução tem sido desenvolvidos a fim realizar estudos de longo prazo com menor interferência direta nos animais. O monitoramento hormonal por métodos não invasivos proporciona o entendimento da biologia reprodutiva de animais e esta é uma das mais poderosas ferramentas de avaliação em zoológicos atualmente (BROWN; WILDT, 1997).

Os metabólitos fecais esteróides podem fornecer dados fundamentais em tópicos como: diagnóstico de gestação, caracterização de ciclos estrais e períodos gestacionais, determinação da proximidade do parto, investigação de anormalidades dos ciclos reprodutivos, detecção de ovulação, eficiência de métodos contraceptivos, sazonalidade reprodutiva, correlações entre reprodução e comportamento social, etc.(PETER et al., 1996, SCHWARZENBERGER et al., 1996; GUIMARÃES et al., 2002).

Não há em literatura a descrição detalhada do ciclo estral desta espécie. O aprimoramento do conhecimento sobre fisiologia reprodutiva destaca-se como uma importante linha de pesquisa de base para a compreensão da biologia reprodutiva da espécie, contribuindo para detalhar sua história de vida e estabelecer seu status de conservação. Esses conhecimentos básicos podem nortear também técnicas de manejo reprodutivo e o desenvolvimento de técnicas de reprodução assistida. Essas técnicas podem garantir a preservação de uma população viável em cativeiro e futuramente pode-se realizar intercâmbio genético entre animais de cativeiro e vida livre, garantindo a viabilidade genética da população em longo prazo. Representa portanto uma importante ferramenta para conservação da espécie.

Esse trabalho objetiva gerar mais informações sobre a endocrinologia reprodutiva da espécie Lycalopex vetulus. Estas informações básicas possibilitarão um maior entendimento da biologia reprodutiva, o que é vital para a implementação de programas de conservação da espécie, seja em cativeiro ou em vida livre. Dentre objetivos específicos estão a caracterização da ciclicidade ovariana de Lycalopex vetulus; e verificar a existência de diferenças entre as concentrações dos referidos metabólitos em um período de 12 meses. 


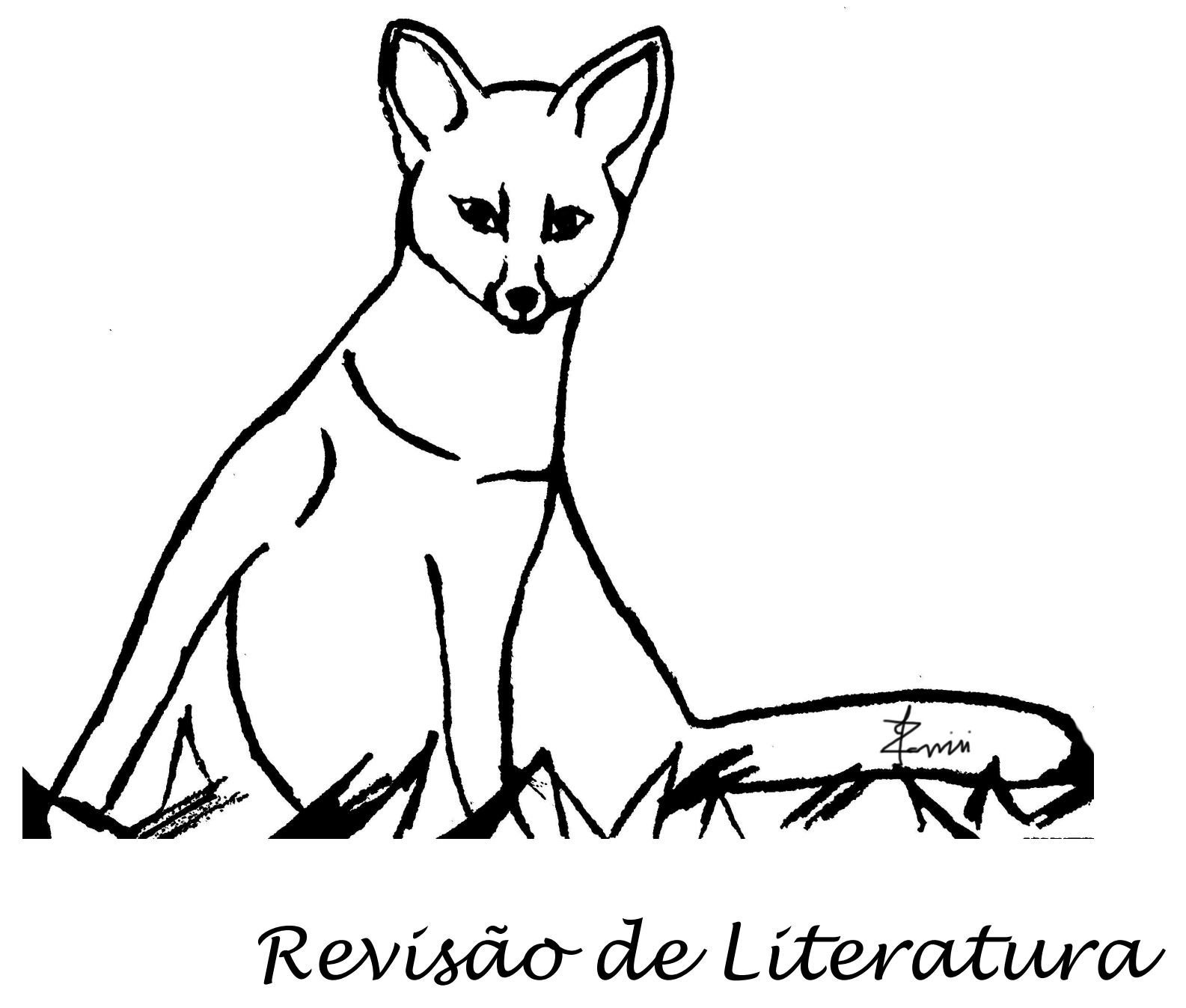




\section{REVISÃO DE LITERATURA}

\subsection{CONSERVAÇÃO DA BIODIVERSIDADE}

O status de conservação da biodiversidade conhecida vem sofrendo um declínio preocupante nas últimas décadas (BUTCHART et al., 2010). E a perda dessa diversidade biológica global e a perturbação de processos ecológicos afetam o bem estar de todas as espécies, incluindo humanos.

O grande aumento do número de espécies em risco de extinção reflete a nossa falha em manter os habitats em que essas espécies ocorrem. Para conter a perda de biodiversidade, que é resultado direto da falta de manejo global do meio ambiente, é preciso uma melhora em diferentes áreas como educação, saúde, bem estar e conservação (KELLY, 1997).

Induzidos pelas mudanças ecológicas encontradas no mundo de hoje, alguns conservacionistas estão começando a questionar a validade de antigos postulados como humanos x natureza, animais livres x cativos e conservação in e ex situ (BRAVERMAN, 2014).

De acordo com Braverman (2014), é necessário reconhecer que para a natureza existir, os seres humanos e não-humanos, terão que reinventá-la e mais ainda, que o nível de "naturalidade" de um lugar é sua originalidade histórica, que se torna irrelevante, até mesmo enganador, quando se considera possíveis estratégias de conservação. Os habitats existentes de um número crescente de espécies estão se tornando menos viáveis para suas sobrevivências, por razões variáveis, incluindo aquecimento global, doenças, seca, fragmentação e desmatamento. Para manter muitas espécies, um habitat alternativo, ou o já existente, deve ser (re) construído e gerenciado.

Os termos in situ e ex situ estão intimamente ligados as concepções históricas de espaço e lugar. Dado o investimento neste ordenamento espacial no século passado, pondo o fim da divisão em in situ/ex situ também irá necessariamente influenciar nossas concepções do local de vida selvagem, lugar de conservação e a relação espacial entre os dois (BRAVERMAN, 2014). 
A diferenciação entre manejo in situ e ex situ está se tornando irrelevante, ao invés, existe uma prática de manejo contínua, variando de populações selvagens autossustentáveis, a populações manejadas dependentes de um certo nível de cuidado humano para se manter.

A abordagem One Plan (um plano) promove participação entre diferentes instituições com o objetivo de considerar toda a população de uma espécie em particular, tanto dentro quanto fora de habitat natural, sob um único plano de manejo (BYERS et al., 2013).

\subsection{PAPEL DOS ZOOLÓGICOS NA CONSERVAÇÃO}

$15 \%$ das espécies de vertebrados ameaçadas de extinção estão representadas em zoológicos de acordo com o programa ISIS (CONDE et al., 2011b).

Programas de Reprodução para a Conservação - CBPs ( Conservation Breeding Programs) já atuaram em 13 de 68 espécies que demonstraram uma melhora de status na lista vermelha da IUCN (CONDE et al., 2013).

Zoológicos tem um extenso conhecimento de cuidados, comportamento e procedimentos veterinários necessários para desenvolver CBPs, e membros da Associação Mundial de Zoológicos e Aquários (WAZA) são, coletivamente, o terceiro maior financiador de conservação de espécies no seu habitat natural (US\$350 milhões/ano), e também estão ativamente envolvidos em muitos desses projetos (GUSSET; DICK, 2010).

Uma das mais importantes associações de zoológico do mundo, a EAZA ( Associação Europeia de Zoológicos e Aquários) tem como missão: Facilitar a cooperação entre a comunidade europeia de zoológicos e aquários com o objetivos de melhorar a qualidade profissional na manutenção dos animais e sua apresentação para a educação do público, e contribuir para a pesquisa científica e a conservação da biodiversidade global. Esse objetivos vão ser atingidos através da estimulação, facilitação e coordenação dos esforços da comunidade em educação, conservação e pesquisa científica, através do reforço da cooperação com todas as organizações relevantes e influenciando legislações na União Europeia (EAZA, 2014). 


\subsection{CARNÍVOROS}

Carnívoros representam algumas das espécies mais reverenciadas no mundo, mas ironicamente eles estão também entre as espécies mais ameaçadas. Carnívoros são perseguidos pelo potencial de impacto para criação de animais domésticos, e suas presas naturais têm sofrido sobrecaça, mesmo em grandes áreas protegidas. Estes animais promovem um serviço ecológico crucial controlando a população de herbívoros e pequenos predadores, e a sua extinção vai provavelmente perturbar as interações predador-presa com efeitos imprevisíveis para as funções do ecossistema (GALETTI et al., 2013).

Carnívoros de diferentes tamanhos desempenham um papel importante na regulação dos ecossistemas, e este papel pode não ser o mesmo entre as diferentes espécies de carnívoros, visto que o impacto de cada uma é influenciado por fatores como tamanho da espécie, demanda metabólica, densidade, sociabilidade, e estratégias de caça (RIPPLE et al., 2014).

Quando predadores de topo de cadeia alimentar são extintos, podemos esperar mudanças contínuas em cascata sobre o papel de comunidades e ecossistemas. A redução contínua de populações de carnívoros vai levar a mudanças na diversidade de espécies de plantas, da biomassa e da produtividade. Em florestas e ecossistemas áridos, a perda de espécies de plantas perenes palatáveis deve interagir com o aquecimento global para aumentar a taxa de desertificação. Como as plantas representam a base da cadeia trófica, estas mudanças na vegetação podem influenciar todas as outras espécies. Os estudos recentes sobre o tema (WILMERS et al., 2003; WILMERS; GETZ, 2005; RIPPLE; BESCHTA, 2012) devem representar apenas a ponta do iceberg. Mudanças na abundância de espécies decorrentes da redução da população de carnívoros podem influenciar diversos processos ecológicos, incluindo dinâmica de doenças (OSTFELD; HOLT, 2004; LEVI et al., 2012), incêndios florestais (HOLDO et al., 2009), e sequestro de carbono (SCHMITZ et al., 2013). Sendo assim, hoje há pesquisas substanciais demonstrando que, ao lado da mudança climática, a extinção de grandes carnívoros é um dos impactos antropogênicos mais importantes na natureza (RIPPLE et al., 2014).

Este cenário associado ao fato de que os carnívoros ocorrem em densidades naturalmente baixas e necessitam de grandes extensões de área para sobreviver, tornam este grupo de espécies muito estratégico de ser estudado como espécies sentinela para 
monitoramentos ecológicos e epidemiológicos.

\subsection{CANÍDEOS BRASILEIROS}

Canídeos com ocorrência no Brasil totalizam seis espécies: raposa-do-campo Lycalopex vetulus (LUND, 1842), graxaim-do-campo - Lycalopex gymnocercus (FISCHER, 1814), cachorro vinagre - Speothos venaticus (LUND, 1842), cachorro-do-mato - Cerdocyon thous (LINNAEUS, 1766), lobo-guará - Chrysocyon brachyurus (ILLIGER, 1815) e cachorro-do-mato-de-orelhas-curtas - Atelocynus microtis (SCLATER, 1883). Dentre estas, L. vetulus é a única espécie com ocorrência aparentemente restrita ao território brasileiro (DALPONTE, 2003), sendo conhecida vulgarmente como raposa-do-campo ou raposinha.

Dentre as seis espécies de canídeos silvestres brasileiros, apenas três espécies (Loboguará, Cachorro vinagre e Cachorro-do-mato) possuem estudos sobre sua fisiologia reprodutiva (DEMATTEO et al., 2006; SONGSASSEN et al., 2006; SOUZA; FURTADO; PAZ, 2012; JOHNSON, 2012; JOHNSON et al., 2014).

O lobo-guará (Chrysocyon brachyurus), figura 1, é uma espécie monoéstrica sazonal, com reprodução de Abril a Junho. O proestro dura cerca de 2 semanas e é caracterizado por secreção vaginal, e aumento do comportamento reprodutivo. A duração do estro varia de 1 a 10 dias. A receptividade sexual e ovulação ocorre na presença do declínio de estrógeno e rápido aumento de progestinas, característica altamente conservada entre os canídeos (SONGSASSEN et al., 2006).

Songsassen (2006) demonstrou que a concentração média de progestinas durante a segunda metade da gestação em fêmeas prenhes que após o parto criaram com sucesso seus filhotes são maiores do que as dosagens médias durante a gestação das fêmeas que posteriormente perderam seus filhotes nos primeiros dias pós parto. Esse estudo indica que a dosagem das concentrações de progestinas durante a gestação em lobos-guarás pode indicar quais filhotes irão precisar de maior atenção e cuidado após o parto. 
Figura 1 - Lobo Guará (Chrysocyon brachyurus)

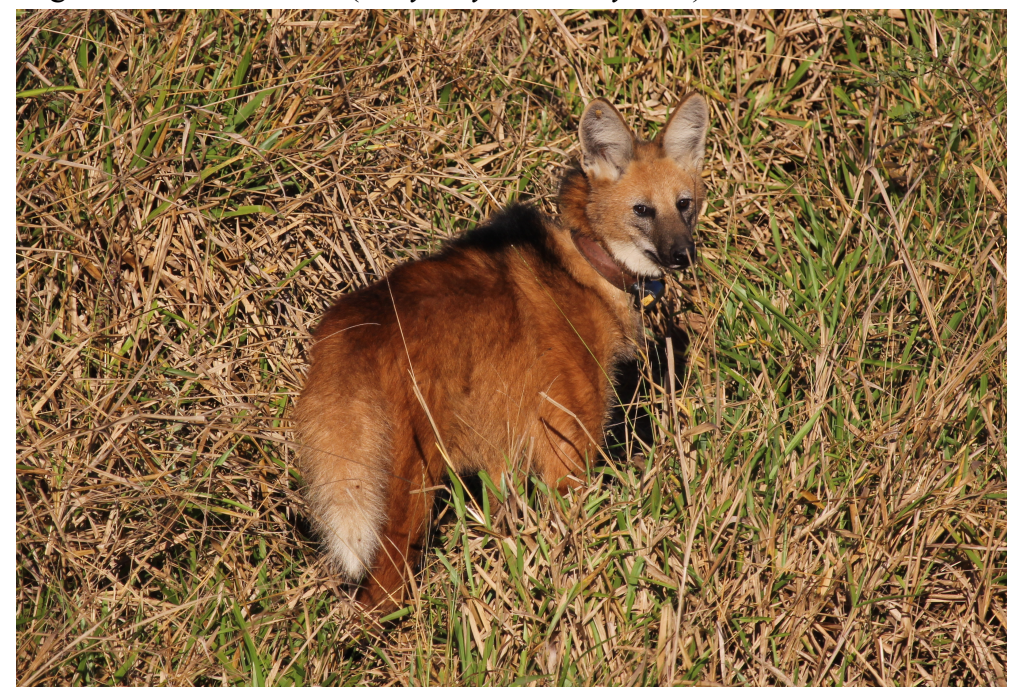

Fonte: (LEMOS, F. G., arquivo pessoal).

O cachorro vinagre (Speothos venaticus), figura 2, diferentemente da maioria dos outros canídeos selvagens, em latitude temperada, não é sazonal, com acasalamento e nascimento de filhotes ocorrendo ao longo do ano, podendo se reproduzir uma segunda vez no ano se perder os filhotes ou se eles forem retirados da mãe. Uma explicação para essa característica pode ser o comportamento social da espécie, a caça cooperativa e a abundância de presas ao longo de todo o ano. A ovulação é espontânea e não depende da presença do macho para ocorrer. No entanto, a presença do macho reduz significativamente o intervalo entre estros e a duração do ciclo, sugerindo que o macho tem um efeito importante na duração da fase lútea no ciclo reprodutivo da fêmea (DEMATTEO et al., 2006).

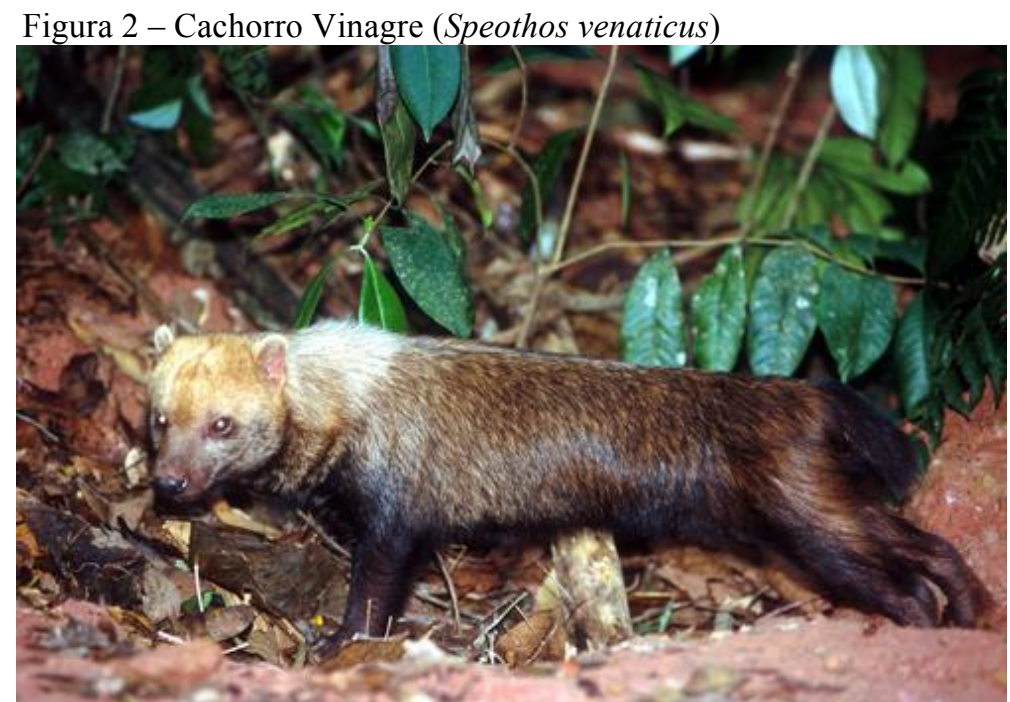

Fonte: (http://www4.icmbio.gov.br/cenap/index.php?id_menu=72 acesso em 10/03/2014). 
O cachorro do mato (Cerdocyon thous), figura 3, é monoéstrico estacional, com reprodução de junho a setembro, e filhotes nascendo de agosto a novembro. A duração da gestação varia de 58 a 60 dias (SOUZA; FURTADO; PAZ, 2012). Machos e fêmeas ficam juntos o ano todo, formando um casal estável que forrageia junto.

Figura 3 - Cachorro-do-Mato (Cerdocyon thous)

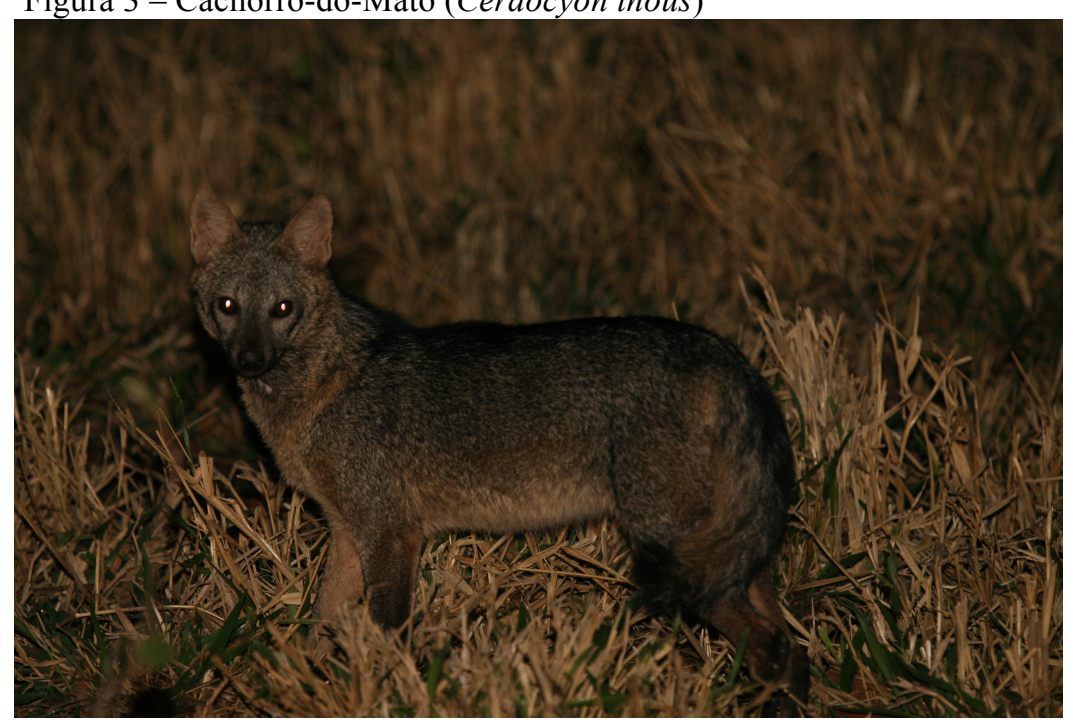

Fonte: (LEMOS, F. G., arquivo pessoal).

\subsection{RAPOSINHA DO CAMPO}

A raposa-do-campo (Lycalopex vetulus), figura 4, é um canídeo de pequeno porte (2,5 a $4 \mathrm{~kg}$ ), endêmico do Brasil Central. Sua distribuição está associada ao bioma cerrado e áreas de transição, incluindo habitats abertos e secos do Pantanal (estado de Mato Grosso). A espécie já foi confirmada nos estados de Minas Gerais, São Paulo, Mato Grosso do Sul, Mato Grosso, Tocantins e Goiás (DALPONTE, 1995; DALPONTE; COURTENAY, 2004; JÁCOMO et al., 2004). 


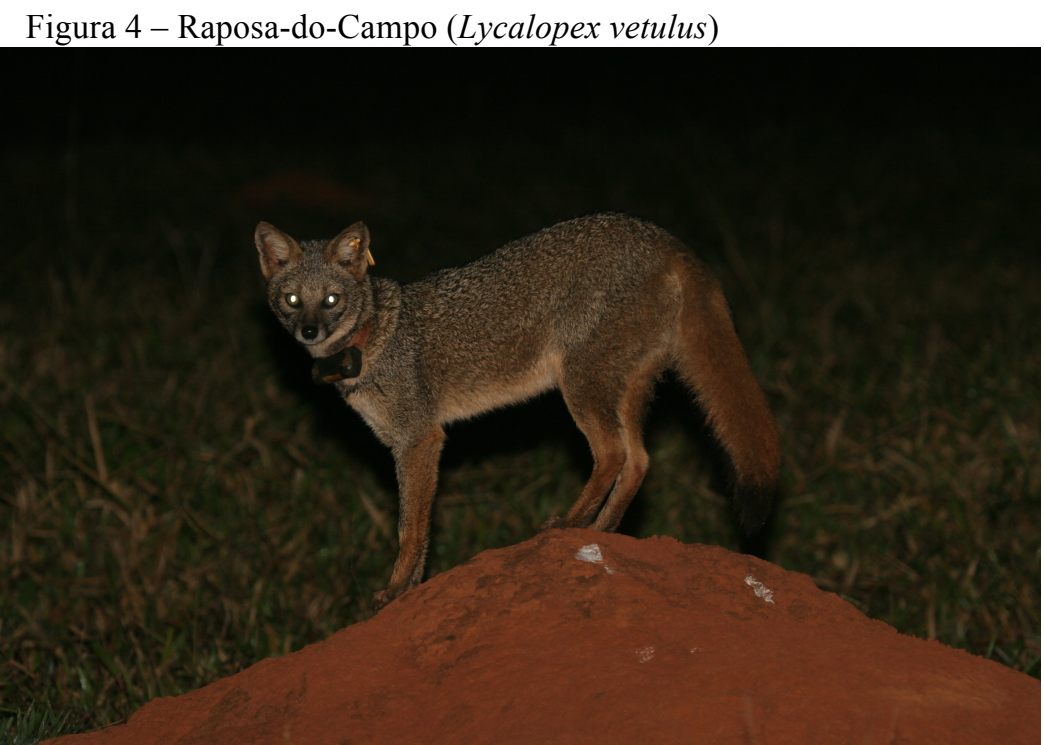

Fonte: (LEMOS, F. G., arquivo pessoal).

O bioma Cerrado é considerado um dos 25 ecossistemas mais ricos em biodiversidade no mundo (MYERS et al., 2000). A região central do Cerrado, entre Minas Gerais (MG) e Goiás (GO), tem sido intensamente impactada por ação antrópica, restando apenas $20 \%$ da cobertura vegetal original (CAVALCANTI; JOLY, 2002).

Os indivíduos de L. vetulus se organizam em pares monogâmicos durante o período reprodutivo e em grupos familiares durante a criação dos filhotes e parte do período prédispersão (DALPONTE, 2003). O período reprodutivo dessa espécie é marcadamente sazonal, com nascimentos ocorrendo uma vez ao ano, no final de julho ou entre a primeira e a segunda semana de agosto (COURTENAY et al., 2006). A duração precisa da gestação é desconhecida, mas com o acasalamento ocorrendo no final de maio e início do junho sugerese que a espécie siga os mesmos padrões dos outros membros do grupo Lycalopex com gestação variando de 53 a 60 dias. Cada fêmea pare de 4 a 5 filhotes por gestação, figura 5 . Os filhotes nascem dentro de tocas feitas por tatus, e são cuidados tanto pela fêmea quanto pelo macho (DALPONTE; COURTENAY, 2004). 


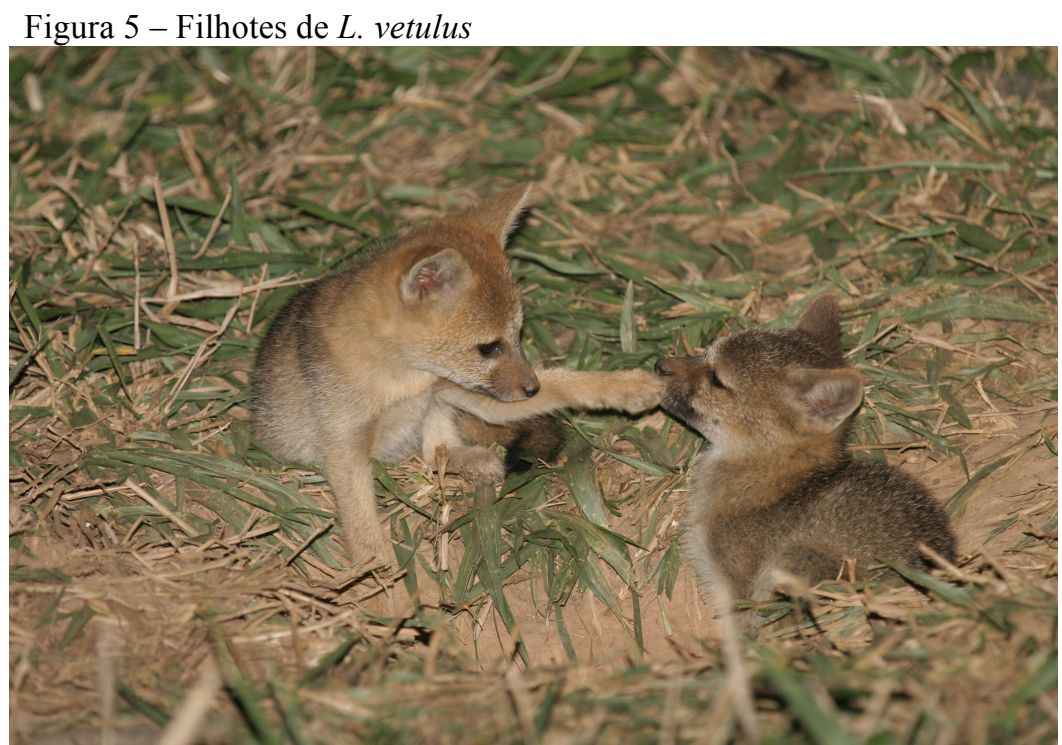

Fonte: (LEMOS, F. G., arquivo pessoal).

Ainda não existem informações na literatura sobre a abundância da espécie dentro da sua área de distribuição. É localmente abundante no cerrado central, aparentemente, mas a população aparenta ser menor do que a do cachorro-do-mato (Cerdocyon thous), que é simpátrico da raposa-do-campo (DALPONTE; COURTENAY, 2004).

A dieta de L. vetulus é típica de um forrageador onívoro, sendo constituída basicamente de cupins e outros artrópodes, frutos e pequenos vertebrados. Há um predomínio no consumo de cupins, principalmente os dos gêneros Syntermes sp e Cornitermes sp, embora coleópteros também representem um importante componente alimentar durante a estação chuvosa (DALPONTE, 2003; DALPONTE; COURTENAY, 2004). Em habitats mais complexos do Cerrado, cerrado sensu stricto e campo sujo, frutos são consumidos em grandes proporções (DALPONTE, 2009; JUAREZ; MARINHO-FILHO, 2002; JÁCOMO et al., 2004; COURTENAY et al., 2006). A raposinha do campo é um forrageador solitário durante quase todo o ano, mas podem ser encontrados forrageando em pares ou com os filhotes (LEMOS; FACURE, 2011).

Apesar de existirem alguns poucos trabalhos acerca de sua dieta e área de vida (JUAREZ; MARINHO-FILHO, 2002; DALPONTE, 2003; COURTENAY et al., 2006; ROCHA, 2006; LEMOS, 2007; LEMOS et al., 2011) pouco ainda é conhecido sobre sua ecologia, abundância e fatores de ameaça. Atualmente é classificada pela IUCN como de menor preocupação (LEMOS; AZEVEDO, 2009). 
No Estado de São Paulo, de acordo com o decreto n ${ }^{\circ} 60.133$ de 7 de fevereiro de 2014 que declara as espécies da fauna silvestre ameaçadas de extinção, as quase ameaçadas e as deficientes de dados no Estado de São Paulo a raposinha do campo (L. vetulus) é classificada como ameaçada de extinção (SÃO PAULO, 2014).

Dentre as principais ameaças a raposa-do-campo está a perda de habitat, pois é uma espécie endêmica do cerrado e esse vem continuamente perdendo sua área para pastagens e agricultura. Outras ameaças ligadas diretamente a ações antrópicas são: envenenamento, caça, predação por cachorro doméstico e atropelamento em rodovias e ferrovias (LEMOS et al., 2011).

\subsection{FISIOLOGIA REPRODUTIVA}

O ciclo estral consiste em eventos fisiológicos que ocorrem entre períodos sucessivos, de receptividade sexual (estro) e ovulações. Cada ciclo é formado por uma fase folicular e uma fase lútea. $\mathrm{Na}$ fase folicular o hormônio predominante é o estradiol dos folículos ovarianos. O estradiol causa mudanças no trato feminino e estimula a receptividade sexual nas fêmeas que possuem ciclo estral. A fase lútea é predominada pela progesterona do corpo lúteo que prepara o trato reprodutivo para a gestação. O período de tempo quando o ciclo estral tem uma parada é chamado de anestro. $\mathrm{O}$ anestro pode ser causado pela gestação, estação do ano, lactação, estresse e patologias (SERGER, 2005).

Apesar das possíveis diferenças entre as espécies, o canídeo com um maior número de informações a cerca de seu ciclo reprodutivo, bem como sobre a produção e liberação de hormônios reprodutivos é o cão doméstico (Canis familiaris). As informações sobre o ciclo reprodutivo desta espécie servem de base para estudos reprodutivos sobre outros canídeos menos estudados.

O ciclo reprodutivo do cão doméstico é diferente da maioria dos outros mamíferos, sendo dividido em 4 fases. $\mathrm{O}$ anestro pode durar de 1 a 6 meses, é marcado pela ausência de cópula, inatividade ovariana, involução uterina e reparação do endométrio. O fim do anestro é marcado por um aumento na secreção pulsátil de hormônio folículo estimulante (FSH) e hormônio luteinizante (LH), induzido pela liberação de GnRH. No final do anestro, o estrógeno e a progesterona estão em níveis basais e a liberação pulsátil de LH aumenta 
levando a foliculogenese do proestro (DAVIDSON; FELDMAN, 2004; BLENDINGER, 2007).

Durante o proestro a fêmea se torna atrativa ao macho, mas ainda não ocorre a cópula. Uma descarga serosanguinolenta de origem uterina está presente, e a vulva aumentada. Os níveis de FSH e LH permanecem baixos durante a maior parte do período, aumentando no pré-ovulatório. O estrógeno aumenta do nível basal no anestro para picos ao final do proestro, enquanto a progesterona permanece em níveis basais até aumentar com o pico de LH. O proestro tem duração de 3 dias a 3 semanas, com média de 9 dias. A fase folicular do ciclo ovariano coincide com o proestro e início do estro (DAVIDSON; FELDMAN, 2004; BLENDINGER, 2007).

O estro tem duração de 3 dias a 3 semanas, com média de 9 dias. O comportamento de estro pode preceder ou seguir o pico de LH. Oocitos primários ovulam dois dias após o pico de LH, e a maturação oocitária ocorre 2 a 3 dias mais tarde. Durante o diestro a fêmea já não é mais atraída pelo macho, os níveis de estrógenos são variavelmente baixos, e a progesterona aumenta atingindo o pico, antes do progressivo declínio no final do diestro. $\mathrm{O}$ diestro dura de 2 a 3 meses na ausência de prenhez (DAVIDSON; FELDMAN, 2004; BLENDINGER, 2007).

Figura 6 - Esquema das mudanças típicas nas concentrações circulantes dos hormônios reprodutivos no ciclo estral da cadela doméstica não prenhe

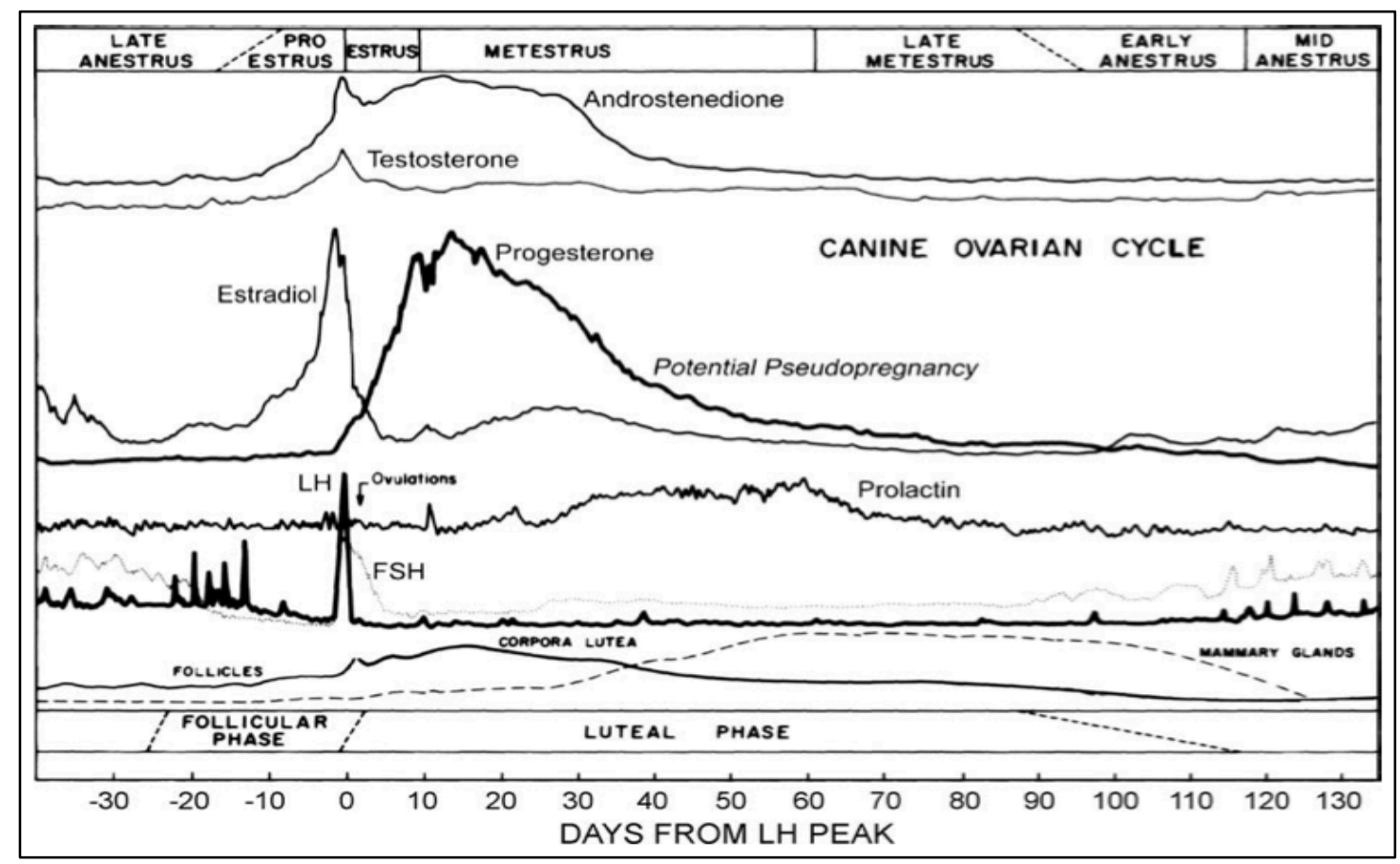

Fonte: (CONCANNON, P. W., 2011). 
O precursor de todos os hormônios esteróides nos vertebrados é o colesterol, composto de 27 átomos de carbono. As glândulas adrenais e gônadas são as fontes mais comuns de hormônios esteróides nos vertebrados (NELSON, 2005). São classificados em: Glicocorticóides (cortisol, corticosterona), Mineralocorticoides (aldosterona), Andrógenos (testosterona), Estrógenos (estradiol, estrona) e Progestinas (progesterona). Na figura 7 podemos observar os hormônios derivados da molécula de colesterol.

Hormônios esteróides são lipossolúveis e atravessam com facilidade as membranas celulares. Consequentemente, eles nunca são estocados, deixam as células em que são produzidos quase imediatamente. O sinal para produzir hormônios esteróides também é um sinal para sua liberação. A resposta ao sinal, no entanto, pode ser bem diferente dependendo do tipo de hormônio, pode demorar horas ou apenas alguns minutos (NELSON, 2005).

Figura 7 - Cascata de hormônios derivados do colesterol

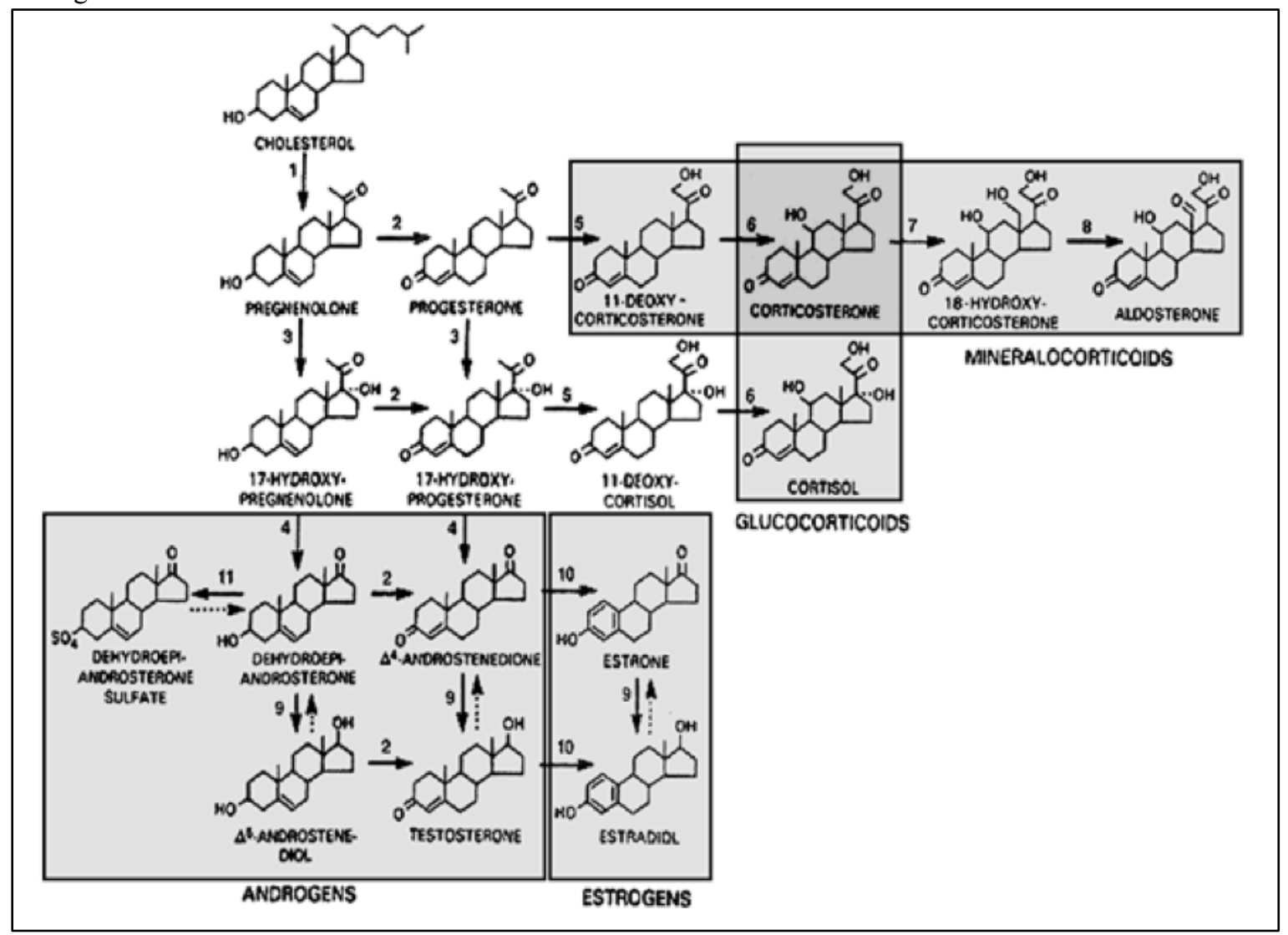

Fonte: (BROWN, J.L., 2008). 


\subsection{HORMÔNIOS GLICOCORTICÓIDES}

A dosagem dos hormônios glicocorticóides vem sendo utilizada como indicadores de estresse nos animais em cativeiro e vida livre. Mas além de estar relacionado com o estresse, os hormônios glicocorticóides possuem diversas funções no organismo. Existe uma importante distinção entre as ações dos glicocorticóides circulantes em níveis baixos e moderados e as ações a altos níveis (estresse) (BUSCH; HAYWARD, 2009).

A nível molecular, os diferentes papéis dos glicocorticóides são modulados por dois tipos de receptores distintos. Em níveis baixos a moderados, glicocorticóides se ligam preferencialmente a um receptor mineralocorticoide de alta afinidade, que ajuda na regulação de energia. Em contraste, ações de resposta emergencial dos glicocorticóides são mediadas em sua maioria pela ligação a um receptor glicocorticóide de baixa afinidade (LANDYS et al., 2006). Como os glicocorticóides se ligam preferencialmente aos receptores de alta afinidade, a ligação com os receptores glicocorticóides de baixa afinidade ocorre em sua maioria após a saturação dos receptores de alta afinidade.

Esse fator explica porque glicocorticóides iniciam ações diferentes quando estão a altos níveis circulantes do que em níveis baixos e moderados. E também fornece o mecanismo (a expressão do receptor), pela qual o limiar para o estresse pode ser modulado por temporada e fase do ciclo de vida (ROMERO, 2002; ROMERO et al., 2005).

Em níveis baixos e moderados os glicocorticóides influenciam o comportamento de se alimentar e atuam no fígado, tecido adiposo e músculos, para manter adequado os níveis circulantes de glicose e ácidos graxos (LANDYS et al., 2006). Glicocorticóides podem ser modulados pela sazonalidade em resposta a mudanças previsíveis no balanço entre o gasto energético de um individuo e a energia disponível no ambiente. A diferença entre o requerimento de energia e a energia disponível é denominada carga alostática. Conforme a carga alostática aumenta, os níveis basais de glicocorticóides tendem a aumentar. Quando a carga alostática não é corrigida e os níveis de glicocorticóides permanecem elevados por dias ou semanas, induzindo o chamado estresse crônico, os glicocorticóides se tornam prejudiciais a saúde e fitness (LANDYS et al., 2006; BUSCH; HAYWARD, 2009). 


\subsection{ENDOCRINOLOGIA COMPORTAMENTAL}

Uma área de estudo com grande importância para o entendimento das relações hormonais e os comportamentos exibidos por determinada espécie, é a endocrinologia comportamental que visa estudar como que os hormônios podem influenciar os comportamentos biológicos e o inverso, como um determinado comportamento ou situação pode influenciar os níveis hormonais (NELSON, 2005).

Em termos de comportamento, podemos pensar que os animais funcionam a partir da combinação de três componentes interativos: (1) sistemas de entrada (sistemas sensoriais), (2) integradores (sistema nervoso central), (3) sistemas de produção ou efetores (músculos) (Figura 8). Hormônios não causam mudanças comportamentais. Ao invés, hormônios influenciam esses três sistemas para que estímulos específicos sejam mais prováveis de suscitar certas respostas em um determinado comportamento ou contexto social. Em outras palavras, hormônios mudam a probabilidade de um comportamento particular ser eminente em uma determinada situação (NELSON, 2005).

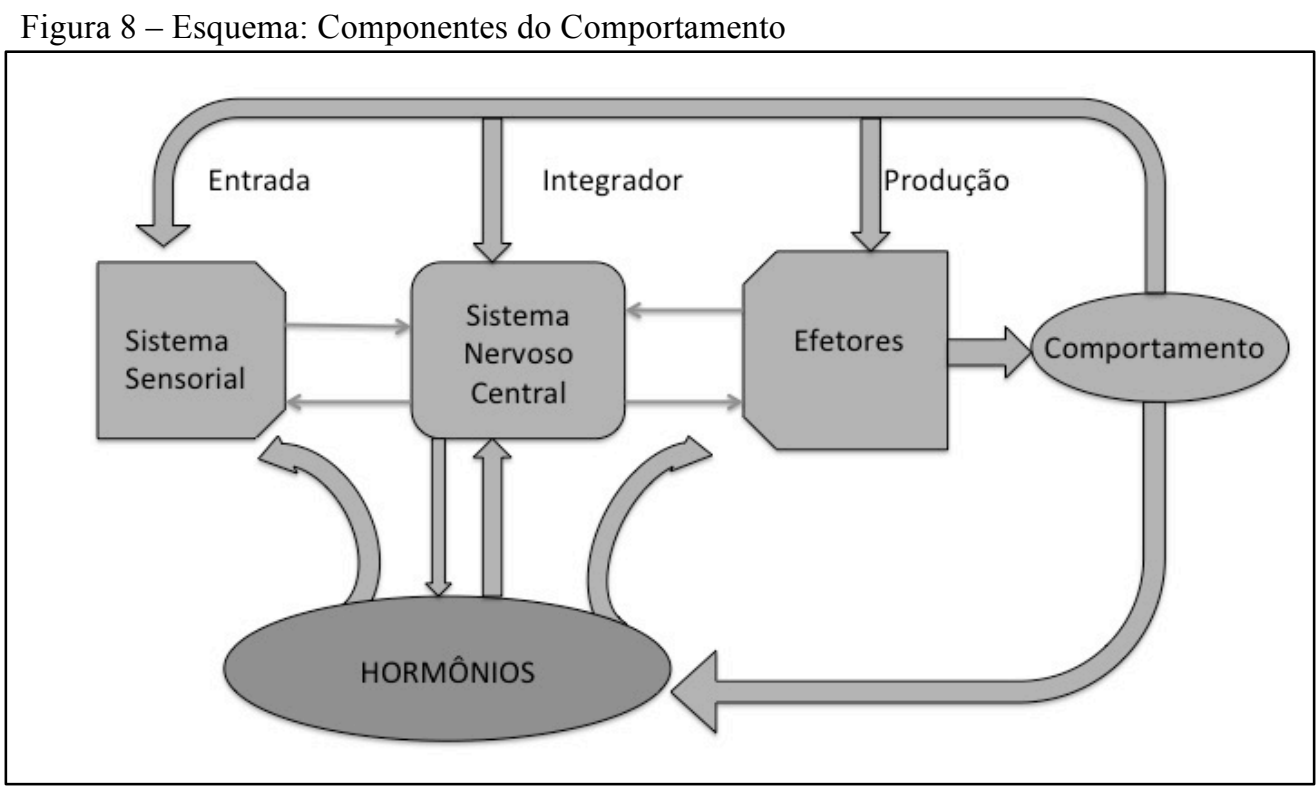

Fonte: (Adaptado de NELSON, R. J., 2005).

A relação recíproca também ocorre, o comportamento pode afetar as concentrações hormonais. Por exemplo, a vista de um intruso no território pode elevar a concentração 
sanguínea de testosterona em um macho residente e ainda estimular vocalização ou comportamento de combate (WINGFIELD, 1988).

\subsection{RITMOS BIOLÓGICOS}

Animais evoluíram restringindo muitos dos seus comportamentos, incluindo a alimentação, acasalamento, e as atividades de locomoção, a nichos temporais específicos em resposta a uma complexa teia de forças seletivas. Esta variação temporal no comportamento presumidamente reflete uma variação temporal na fisiologia básica. Todos os processos fisiológicos variam com o tempo. Especificamente, a secreção endócrina varia marcadamente com o tempo de minutos (ritmos infradianos), dias (ritmos circadianos) e de um ano (ritmos ultradianos), dependendo do hormônio. Devido a essa variação temporal na função endócrina, o comportamento, e mais especificamente o comportamento mediado por hormônios, exibe uma pronunciada variação temporal. Uma grande parte dessa variação temporal é regulada por relógios biológicos (NELSON, 2005).

Mecanismos temporais interagem com substratos neuroendócrinos da função reprodutiva para garantir um timing apropriado para as atividades reprodutivas. Em mamíferos, mudanças sazonais na atividade reprodutiva estão geralmente associados com mudanças na secreção de gonadotrofina pituitária. Essas mudanças levam a mudanças no crescimento gonadal e secreção de hormônio esteroide sexual. Os fatores exógenos que mediam as mudanças sazonais na atividade reprodutiva atuam primariamente via ações no eixo Hipotalâmico-pituitário. O fotoperíodo também pode alterar a habilidade dos hormônios esteroides em ativar o comportamento sexual (NELSON, 2005).

Durante o período reprodutivo, um importante mecanismo que regula a secreção pituitária de FSH e LH é o sistema de feedback hormônio gonadal. Esse sistema é especialmente importante para regular o número de folículos ovarianos que maturam durante cada ciclo ovulatório. Conforme os folículos se tornam maduros, eles produzem um aumento de estrógeno, resultando em um declínio do nível de gonadotrofinas e cessação do recrutamento de novos folículos. 
Os mecanismos que mediam as mudanças sazonais no status reprodutivo também afetam o comportamento. Uma grande variedade de comportamentos marcadamente reprodutivos variam em relação ao status reprodutivo do animal. Na maioria dos vertebrados, o acasalamento ocorre ao mesmo tempo do pico de produção de gametas. Como a gametogênese é um processo esteróide dependente em todos os vertebrados, a regulação esteróide hormonal do acasalamento geralmente promove uma coordenação temporal entre a maturação gamética e acasalamento, mas existem exceções (NELSON, 2005).

Com relação aos hormônios glicocorticóides, o número e tipo de estressores que os animais encontram variam sazonalmente (BREUNER et al., 1999). Muitas adaptações energéticas aparentemente evoluíram de forma a atenuar a resposta estressora durante o inverno. Nesse período, a pouca reserva energética pode limitar a habilidade do animal em lidar com o estresse. Além de variações sazonais, ocorrem variações circadianas de acordo com a variação de demanda energética. $\mathrm{O}$ aumento na liberação de glicocorticóides momentos antes do despertar diariamente eleva a concentração sanguínea de glicose em antecipação ao aumento da demanda energética associado ao despertar. Nesse sentido, podemos esperar um aumento na secreção de glicocorticóides durante as fases de maior demanda energética, como defesa territorial, migração, baixas temperaturas e períodos reprodutivos.

Muitas interações hormônios - comportamento aparentam estar conectadas com ciclos reprodutivos, mas não existem estudos suficientes sobre como esses fenômenos se conectam e se influenciam (NELSON, 2005).

\subsection{DOSAGEM HORMONAL NÃO INVASIVA}

Métodos tradicionais do estudo dos hormônios foram desenvolvidos através de amostras sanguíneas. Porém a utilização do sangue para pesquisas sobre fisiologia reprodutiva é muito restritiva, principalmente em animais selvagens, devido a quantidade de amostras repedidas necessárias e a dificuldade da sua obtenção.

Devido a essa dificuldade, métodos alternativos de pesquisa em fisiologia da reprodução tem sido desenvolvidos a fim realizar estudos de longo prazo com menor interferência direta nos animais. Novas técnicas vem continuamente sendo aprimoradas nas 
últimas décadas para a dosagem de hormônios a partir das fezes, urina, saliva, pelos e tecido adiposo. $\mathrm{O}$ monitoramento hormonal por métodos não invasivos proporciona o entendimento da biologia reprodutiva de animais e esta é uma das mais poderosas ferramentas de avaliação em zoológicos atualmente (BROWN; WILDT, 1997).

Estes métodos não invasivos são em particular usados porque amostras de fezes, urina, pelo, etc. podem ser facilmente obtidas sem incômodo ao animal e sem colocá-lo em perigo durante a captura (WASSER et al., 2000). Consequentemente, amostras podem ser coletadas em intervalos regulares ao longo do tempo.

O metabolismo e excreção de hormônios esteróides variam substancialmente entre espécies, e por essa razão todo monitoramento endócrino não-invasivo deve ser previamente validado para a espécie antes de sua aplicação (PETER et al., 1996; SCHWARZENBERGER et al., 1996).

Hormônios estrogênicos são excretados predominantemente pelas fezes em carnívoros. Em felinos, a maior parte dos esteróides são excretados pelas fezes, em canídeos apenas aproximadamente $60 \%$ aparenta ser excretado pelas fezes. A determinação do aumento de estrógeno pré-ovulatório, seguido de um aumento sustentados dos níveis de progesterona em espécies felinas e caninas demonstraram ser um indicador confiável de ovulação (BROWN et al., 1994; WASSWER; VELLOSO; RODDEN, 1995; SCHWARZENBERGER et al., 1996). Em adição, a ovulação no cão doméstico é caracterizada por um pico pré-ovulatório de andrógenos fecais juntamente com o pico de estradiol (GUDERMUTH et al., 1998).

Uma preocupação com o monitoramento hormonal através das fezes era que mudanças na dieta e variações na concentração de água entre amostras de fezes influenciaria a concentração de esteróides fecais, sendo necessário padronizar a alimentação. Porém estudos concluíram que essa padronização não era necessária pra os esteróides fecais. Entretanto para algumas espécies como carnívoros e elefantes, a liofilização das amostras de fecais é vantajosa; após a dissecação, fragmentos de ossos e plantas podem ser removidos (SCHWARZENBERGER et al., 1996).

Os metabólitos fecais esteróides podem fornecer dados fundamentais em tópicos como: diagnóstico de gestação, caracterização de ciclos estrais e períodos gestacionais, determinação da proximidade do parto, investigação de anormalidades dos ciclos reprodutivos, detecção de ovulação, eficiência de métodos contraceptivos, sazonalidade 
reprodutiva, correlações entre reprodução e comportamento social, etc. (PETER et al., 1996; SCHWARZENBERGER et al., 1996; GUIMARÃES et al., 2002). 


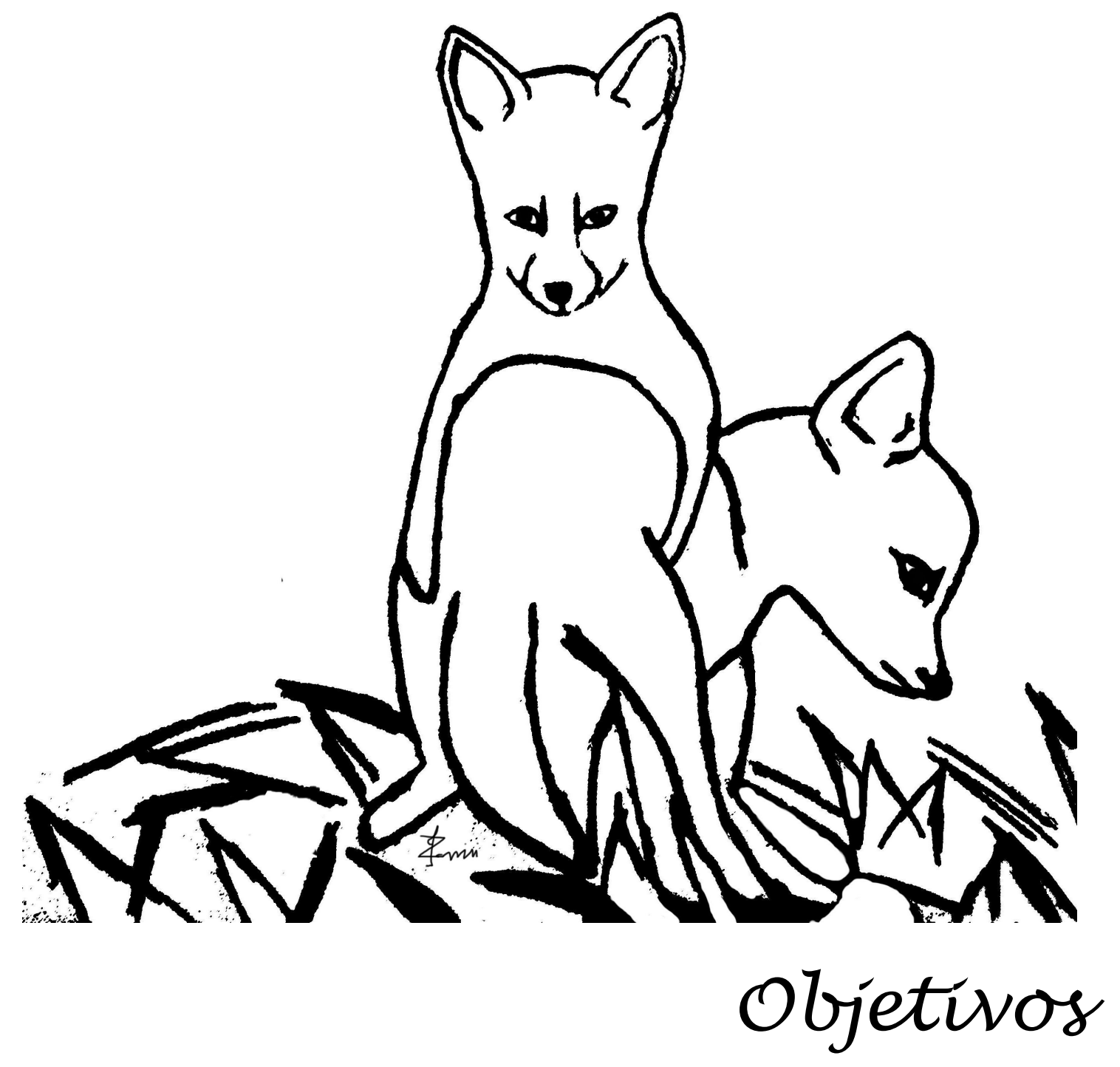




\section{OBJETIVOS}

O objetivo do presente projeto foi gerar mais informações sobre a endocrinologia reprodutiva da espécie Lycalopex vetulus. Estas informações básicas possibilitarão um maior entendimento da biologia reprodutiva, o que é vital para a implementação de programas de conservação da espécie, seja em cativeiro ou em vida livre.

Os objetivos específicos foram:

-Validar a técnica de extração e dosagem dos metabolitos fecais de progesterona e estradiol para Lycalopex vetulus.

-Caracterizar a ciclicidade ovariana de Lycalopex vetulus, mantidos em cativeiro, com o uso de método não-invasivo: Extração e mensuração de metabólitos fecais de progesterona e estradiol.

-Caracterizar a excreção de metabólitos fecais de glicocorticóides em fêmeas de Lycalopex vetulus, mantidas em cativeiro, ao longo de 12 meses.

-Verificar se existem diferenças entre as concentrações dos referidos metabólitos em um período de 12 meses. 


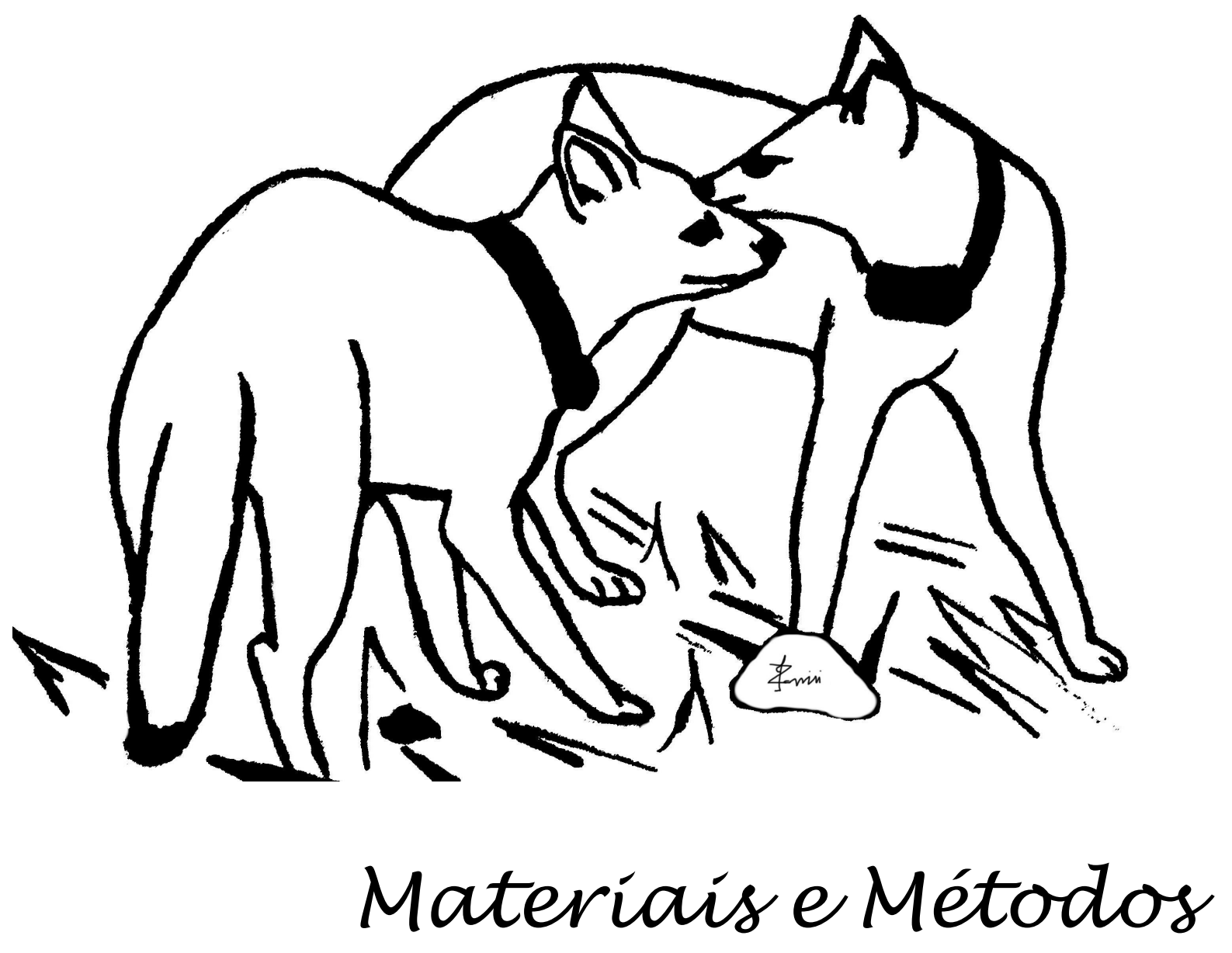




\section{MATERIAIS E MÉTODOS}

\subsection{ANIMAIS}

Anterior ao início do estudo foi feito um levantamento da presença da espécie Lycalopex vetulus nas principais instituições mantenedoras de animais selvagens do Brasil nos estados de São Paulo, Minas Gerais, Goiás, Rio de Janeiro, Paraná, Santa Catarina e Rio Grande do Sul. Foi também realizado um questionamento a Sociedade de Zoológicos do Brasil sobre onde encontrar essa espécie. Dentre as cerca de 20 instituições que responderam ao questionamento do projeto, foi encontrada essa espécie apenas naquelas localizadas no estado de São Paulo, mais especificamente em seis instituições. Dentre estas seis, apenas uma delas não teve interesse em participar do projeto de pesquisa. Portanto, o estudo utilizou $89 \%$ dos animais encontrados em cativeiro no país durante o período do experimento.

Foram utilizados no presente estudo 8 fềmeas, adultas da espécie Lycalopex vetulus, distribuídos em cinco instituições diferentes do Estado de São Paulo, conforme descrito abaixo:

Uma fêmea no Parque Ecológico de Americana em Americana, SP (2245'7.98"S / 47²1'10.49"O), onde está com um macho no recinto. Duas fêmeas no Zoológico de Piracicaba (2241'41.98"S / 47³9'5.52"O). Uma fêmea no Parque Ecológico Dr. Antônio Teixeira Vianna em São Carlos, SP (2159'5.29"S / 4752'32.34"O). Duas fêmeas no Bosque e Zoológico Municipal Dr. Fábio de Sá Barreto em Ribeirão Preto, SP (21¹0'22.41"S / 4748'10.24"O). Duas fêmeas no Parque Zoológico Municipal Quinzinho de Barros na cidade de Sorocaba, SP (2330'19.31"S / 47²6'19.67"O).

A idade dos animais foi baseada nas informações fornecidas pelas instituições mantenedoras dos animais, mas em alguns casos só temos certeza do tempo que o animal já está na instituição, onde chegou adulto. Devido a isso na tabela 1 estão as idades conhecidas dos animais, e nos casos onde o animal já chegou adulto, e não se conhece o seu histórico existe o sinal de "maior que"( $>$ ) indicando que o animal possui ao menos aquela idade, mas não é conhecida sua idade real. 
Tabela 1 - Distribuição dos animais participantes do estudo nas instituições, identificação de cada individuo, idade aproximada e histórico de reprodução, 2014

\begin{tabular}{|c|c|c|c|c|c|}
\hline Instituição & $\begin{array}{l}\mathrm{N}^{\mathrm{o}} \text { de Fêmeas } \\
\text { de } L . \text { vetulus }\end{array}$ & $\begin{array}{l}\text { Identificação } \\
\text { No projeto }\end{array}$ & Microchip & $\begin{array}{c}\text { Idade } \\
\text { estimada }\end{array}$ & $\begin{array}{l}\text { Histórico de } \\
\text { Reprodução }\end{array}$ \\
\hline Parque Ecológico de Americana & 1 & Fêmea 1 & 250843 & $>7$ & Negativo \\
\hline \multirow{2}{*}{ Zoológico de Piracicaba, SP } & \multirow{2}{*}{2} & Fêmea 2 & 161505 & $>8$ & Negativo \\
\hline & & Fêmea 3 & 4077141F5E & $>3$ & Negativo \\
\hline $\begin{array}{c}\text { Parque Ecológico São Carlos - } \\
\text { Dr. Antônio Teixeira Vianna- } \\
\text { São Carlos, SP }\end{array}$ & 1 & Fêmea 4 & 86249 & 12 & Positivo \\
\hline Parque Zoológico Municipal & & Fêmea 5 & 493331 & $>5$ & Positivo \\
\hline $\begin{array}{l}\text { Quinzinho de Barros - } \\
\text { Sorocaba, SP }\end{array}$ & 2 & Fêmea 6 & 63832 & $>5$ & Negativo \\
\hline Bosque e Zoológico Municipal & & Fêmea 7 & 123909 & 3 & Negativo \\
\hline $\begin{array}{c}\text { Dr. Fábio de Sá Barreto- } \\
\text { Ribeirão Preto, SP }\end{array}$ & 2 & Fêmea 8 & 123918 & 2 & Negativo \\
\hline
\end{tabular}

Legenda: Na idade estimada dos animais, o sinal "maior que" ( $>$ ) representa os animais que já chegaram adultos em suas instituições e não se conhece seu histórico, assim como sua idade real.

\subsubsection{Parque Ecológico de Americana - Americana - SP}

Nesse zoológico um casal de raposa-do-campo divide o mesmo recinto. Para a realização das coletas de fezes 3 vezes por semana da fêmea (Figura 9), o casal era separado no final do dia anterior à coleta e na manhã seguinte era realizada a coleta das fezes, sendo em seguida o animal liberado para o recinto de exposição, junto ao outro indivíduo. Este casal chegou em 2010, vindo do Parque do Ingá, onde chegou em 2007 levado pela polícia ambiental. 
Figura 9 - Fêmea de L. vetulus (Fêmea 1) do Parque Ecológico de Americana

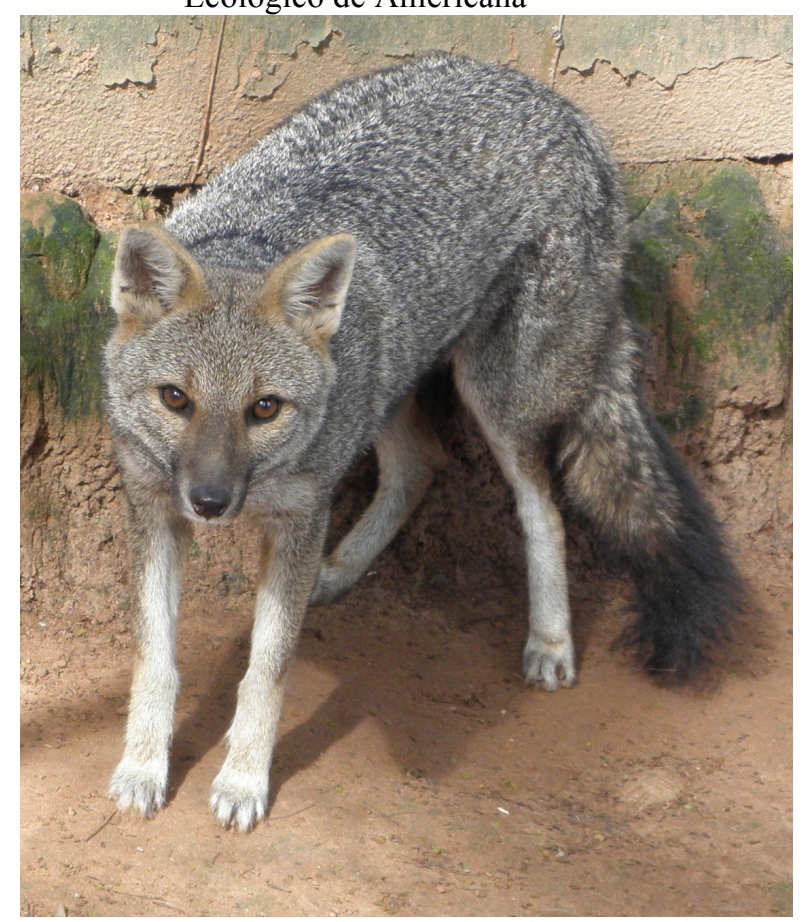

Fonte: (CANDEIAS, I. Z., 2014).

O recinto de exposição mede $61,5 \mathrm{~m}^{2}$ e possui sombreamento natural em parte do recinto, tocas artificiais, substrato de terra batida com áreas gramadas, cambiamento com $3,4 \mathrm{~m}^{2}$ feito de alvenaria com cobertura e com um solário extra, separado do recinto de exposição com $14,5 \mathrm{~m}^{2}$.

Na figura 10 a seguir temos a ilustração do recinto das raposas-do-campo: 
Figura 10 - Ilustração do recinto das L. vetulus no Parque Ecológico de Americana

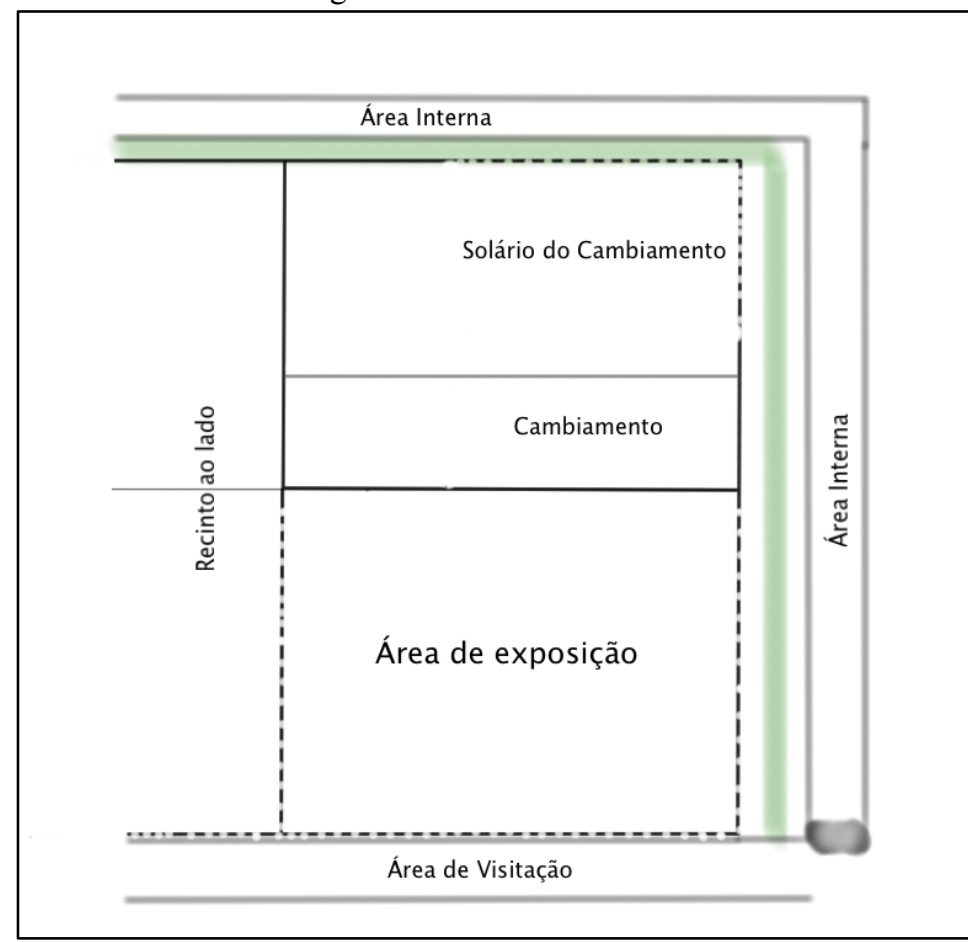

Legenda: As linhas contínuas representam paredes de alvenaria e as linhas tracejadas grade metálica; a área verde representa a vegetação em altura baixa $(40 \mathrm{~cm})$ entre o guarda corpo e a grade metálica.

A alimentação era fornecida as raposas-do-campo à tarde e está descrita na tabela 2:

Tabela 2 - Composição da dieta oferecida aos L. vetulus no Parque Ecológico de Americana

\begin{tabular}{|c|c|c|c|c|c|c|c|c|c|}
\hline Item & Apresentação & $2^{a}$ & $3^{\mathrm{a}}$ & $4^{\mathrm{a}}$ & $5^{\mathrm{a}}$ & $6^{\mathrm{a}}$ & Sáb & Dom & Gramas \\
\hline Cenoura & Ralada & $\mathrm{X}$ & & $\mathrm{X}$ & & $\mathrm{X}$ & & $\mathrm{X}$ & 50 \\
\hline Beterraba & Ralada & & $X$ & & $X$ & & $\mathrm{X}$ & & 50 \\
\hline Banana & Picada & & $X$ & & $X$ & & X & & 50 \\
\hline Mamão & Picado & & $X$ & & $\mathrm{X}$ & & $X$ & & 50 \\
\hline Maçã & Ralada & $\mathrm{X}$ & & $\mathrm{X}$ & & $X$ & & $\mathrm{X}$ & 50 \\
\hline $\begin{array}{l}\text { Pescoço de } \\
\text { Frango }\end{array}$ & Picado & X & $X$ & $\mathrm{X}$ & $\mathrm{X}$ & $X$ & X & $\mathrm{X}$ & 100 \\
\hline Carne Bovina & Picada & $\mathrm{X}$ & $X$ & $\mathrm{X}$ & $X$ & $\mathrm{X}$ & $\mathrm{X}$ & $\mathrm{X}$ & 100 \\
\hline Coração & Vísceras & & & $\mathrm{X}$ & & $X$ & & $\mathrm{X}$ & 50 \\
\hline Fígado & Vísceras & & $X$ & & & & $\mathrm{X}$ & & 50 \\
\hline Ovo & Cozido & $\mathrm{X}$ & & & $X$ & & & & $1 / 2 u$ \\
\hline Ração canina & Seca & $X$ & $X$ & $\mathrm{X}$ & $X$ & X & $\mathrm{X}$ & X & 70 \\
\hline $\begin{array}{l}\text { Carbonato de } \\
\text { Cálcio }\end{array}$ & & $X$ & $X$ & $\mathrm{X}$ & $\mathrm{X}$ & $\mathrm{X}$ & $\mathrm{X}$ & $\mathrm{X}$ & 5 \\
\hline
\end{tabular}




\subsubsection{Zoológico de Piracicaba - Piracicaba - SP}

As duas fêmeas dessa instituições são provenientes do Parque Ecológico de Americana, uma chegou em 2011 (Figura 11) e outra em 2012 (Figura 12), um pouco antes do inicio das coletas, por esse motivo permaneceram separadas durante todo o período de coleta, se revezando entre o recinto de exposição, o cambiamento e o solário aos fundos do recinto.

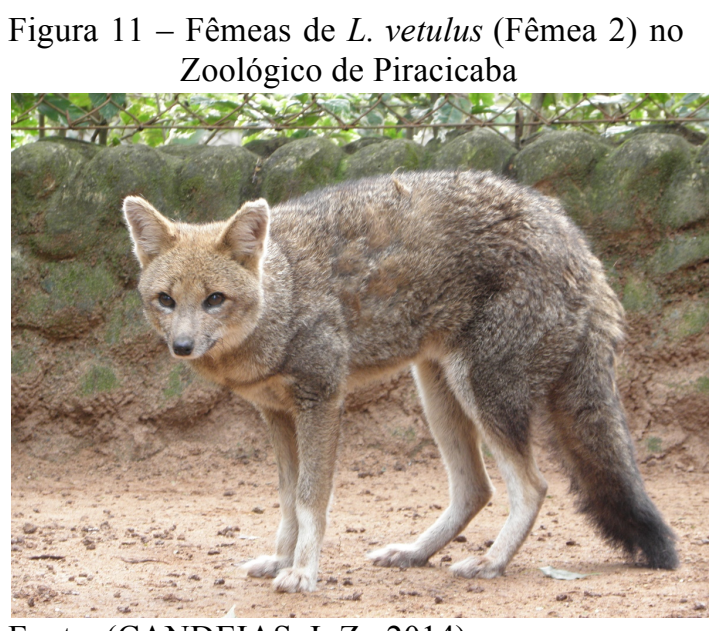

Fonte: (CANDEIAS, I. Z., 2014).
Figura 12 - Fêmeas de L. vetulus (Fêmea 3) no Zoológico de Piracicaba

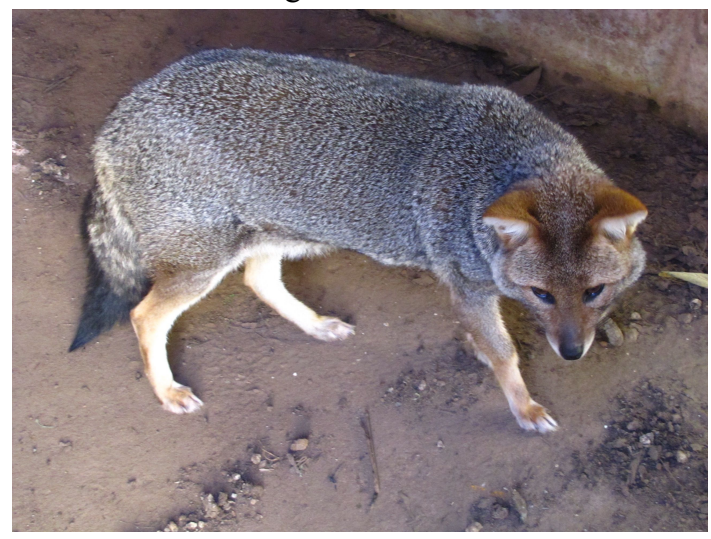

Fonte: (CANDEIAS, I. Z., 2014).

O recinto da raposa-do-campo mede $70 \mathrm{~m}^{2}$, em forma de um quadrado, com sombreamento natural, piso de terra, capim e grama, vegetação natural, tanque que serve também de bebedouro com água corrente, cambiamento de $3 \mathrm{~m}^{2}$, solário do cambiamento de $8 \mathrm{~m}^{2}$, barreira do público com guarda corpo em metal, e tela de metal.

$\mathrm{Na}$ figura 13 a seguir está representado o esquema do recinto das raposas-do-campo na instituição e na tabela 3 a composição da dieta oferecida aos animais. 
Figura 13 - Ilustração do recinto da L. vetulus no Zoológico de Piracicaba

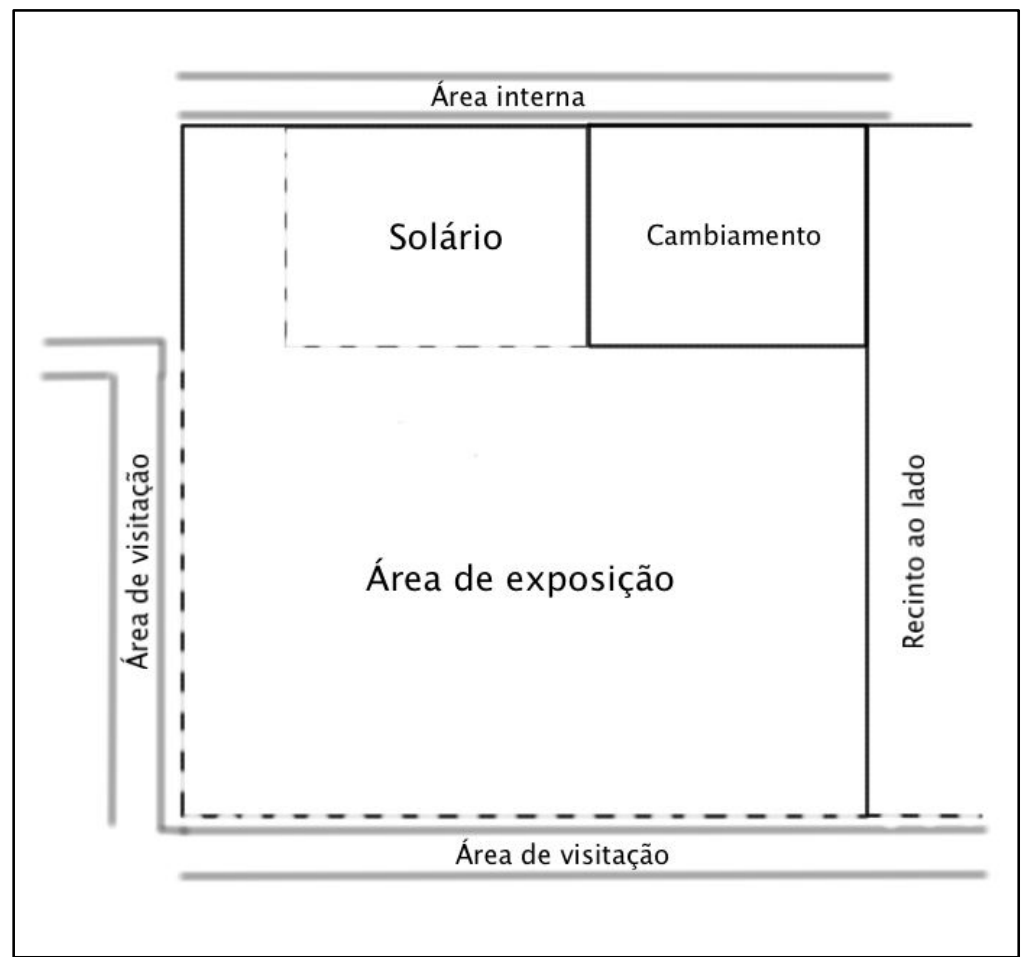

Legenda: As linhas contínuas representam paredes de alvenaria e as linhas tracejadas grade metálica.

Tabela 3 - Composição da dieta oferecida aos L. vetulus no Zoológico de Piracicaba

\begin{tabular}{|c|c|c|c|c|c|c|c|c|c|}
\hline Item & Apresentação & Quantidade & $2^{a}$ & $3^{a}$ & $4^{\mathrm{a}}$ & $5^{\mathrm{a}}$ & $6^{\mathrm{a}}$ & Sáb & Dom \\
\hline Banana & Picada & 1 unidade & $\mathrm{X}$ & $\mathrm{X}$ & $\mathrm{X}$ & $\mathrm{X}$ & $\mathrm{X}$ & $\mathrm{X}$ & $\mathrm{X}$ \\
\hline Mamão & $\begin{array}{l}\text { Com casca e } \\
\text { sementes }\end{array}$ & 1 rodela de $2 \mathrm{~cm}$ & $\mathrm{X}$ & $\mathrm{X}$ & $\mathrm{X}$ & $\mathrm{X}$ & $\mathrm{X}$ & $\mathrm{X}$ & $\mathrm{X}$ \\
\hline Ração canina & Pellets & 150 gramas & $\mathrm{X}$ & $\mathrm{X}$ & $\mathrm{X}$ & $\mathrm{X}$ & $\mathrm{X}$ & $\mathrm{X}$ & $\mathrm{X}$ \\
\hline Beterraba cozida & Cozida & 1 unidade pequena & $\mathrm{X}$ & $\mathrm{X}$ & $\mathrm{X}$ & $\mathrm{X}$ & $\mathrm{X}$ & $\mathrm{X}$ & $\mathrm{X}$ \\
\hline Cenoura & Cozida rodelas & 1 unidade & $\mathrm{X}$ & $\mathrm{X}$ & $\mathrm{X}$ & $\mathrm{X}$ & $\mathrm{X}$ & $\mathrm{X}$ & $\mathrm{X}$ \\
\hline Ovo & $\begin{array}{l}\text { Cozido com casca } \\
\text { inteiro }\end{array}$ & 1 unidade & $\mathrm{X}$ & $\mathrm{X}$ & $\mathrm{X}$ & $\mathrm{X}$ & $\mathrm{X}$ & $\mathrm{X}$ & $\mathrm{X}$ \\
\hline Abacaxi & Sem casca picado & 1 rodela $3 \mathrm{~cm}$ & $\mathrm{X}$ & & & & & & \\
\hline Abacate & $\begin{array}{l}\text { Sem casca e } \\
\text { caroço em cubos }\end{array}$ & $1 / 2$ unidade pequena & & $\mathrm{X}$ & & & $\mathrm{X}$ & & \\
\hline
\end{tabular}

Fonte: (ZOOLÓGICO DE PIRACICABA). 


\subsubsection{Parque Ecológico São Carlos - Dr. Antônio Teixeira Vianna - São Carlos - SP}

O recinto da raposa-do-campo mede $200 \mathrm{~m}^{2}$, em forma de um polígono irregular, com sombreamento natural e artificial, piso de terra, capim e grama, vegetação natural, abrigo em alvenaria e tocas artificiais, bebedouro com água corrente, tanque com $2 \mathrm{~m}^{2}$, cambiamento de $25 \mathrm{~m}^{2}$, maternidade de $10 \mathrm{~m}^{2}$, barreira do público com guarda corpo em madeira e fio de aço e fosso seco (Figura 14).

A instituição possui apenas uma fêmea (Figura 15), que chegou ao Parque em 24/10/2002, proveniente do Zoológico Municipal de Ribeirão Preto. Por possuir apenas um animal da espécie, a coleta ocorreu sem problemas, com o animal tendo acesso a todas as áreas do recinto durante todo o período de coleta. A dieta fornecida a L. vetulus está representada na tabela 4 .

Figura 14: Ilustração do recinto da L. vetulus no Parque Ecológico de São Carlos

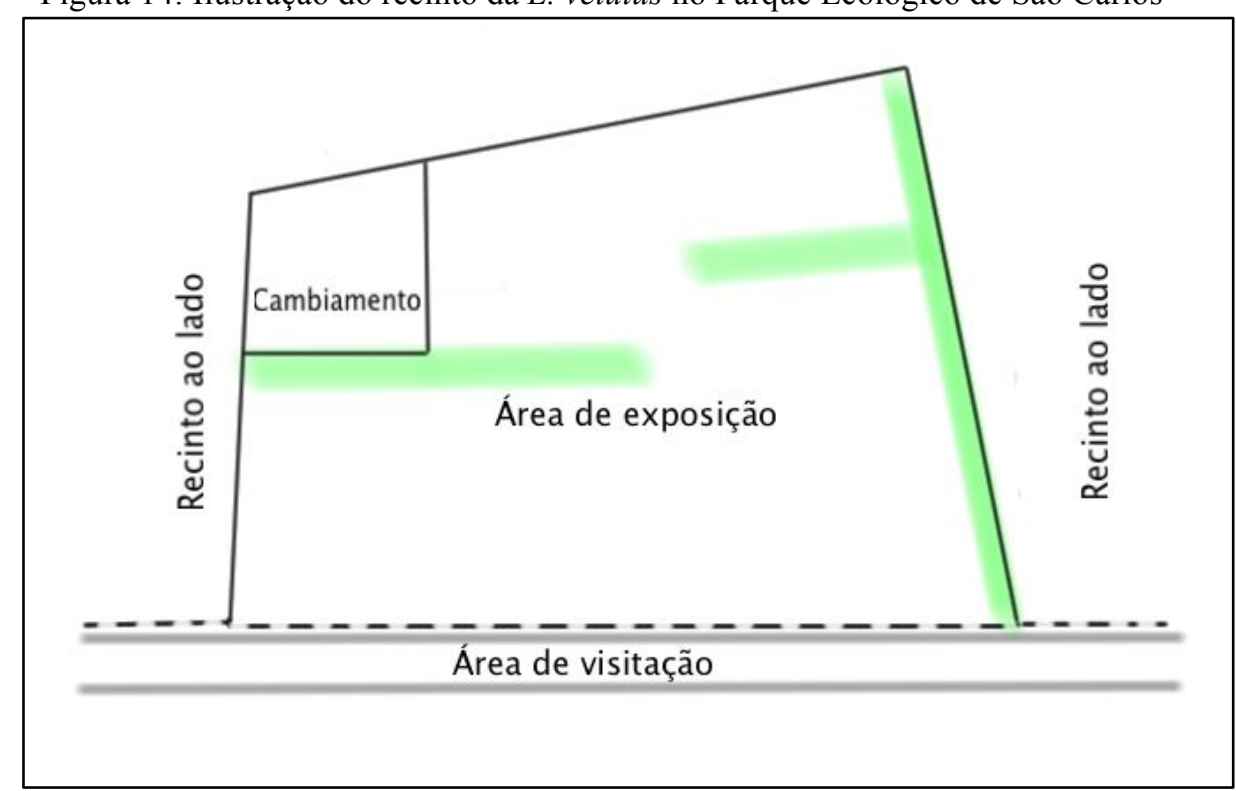

Legenda: As linhas contínuas representam paredes de alvenaria e as linhas tracejadas a visão aberta do público, que não possui grades, apenas um fosso seco e um guarda corpo de madeira; a área verde representa a vegetação alta que não permite o público ver toda a extensão do recinto. 
Figura 15 - Fêmea de L. vetulus (Fêmea 4) do Parque Ecológico São Carlos - Dr. Antônio Teixeira Vianna

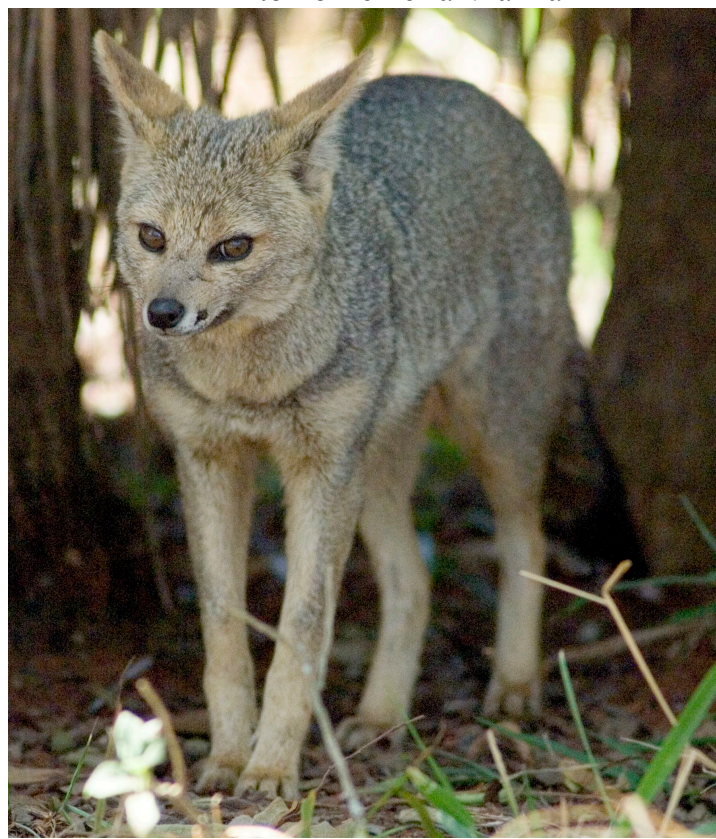

Fonte: (Parque Ecológico São Carlos, 2014).

Tabela 4 - Composição da dieta oferecida aos L. vetulus no Parque Ecológico de São Carlos

\begin{tabular}{llllllllll}
\hline Item & Apresentação & $2^{\mathrm{a}}$ & $3^{\mathrm{a}}$ & $4^{\mathrm{a}}$ & $5^{\mathrm{a}}$ & $6^{\mathrm{a}}$ & Sáb & Dom & Gramas \\
\hline Banana & Picada & $\mathrm{X}$ & $\mathrm{X}$ & $\mathrm{X}$ & $\mathrm{X}$ & $\mathrm{X}$ & $\mathrm{X}$ & $\mathrm{X}$ & 50 \\
Mamão & Picado & $\mathrm{X}$ & $\mathrm{X}$ & $\mathrm{X}$ & $\mathrm{X}$ & $\mathrm{X}$ & $\mathrm{X}$ & $\mathrm{X}$ & 50 \\
$\begin{array}{l}\text { Carne Bovina ou } \\
\text { de frango }\end{array}$ & $\begin{array}{l}\text { Moída misturada } \\
\text { na ração }\end{array}$ & $\mathrm{X}$ & $\mathrm{X}$ & $\mathrm{X}$ & $\mathrm{X}$ & $\mathrm{X}$ & $\mathrm{X}$ & $\mathrm{X}$ & 100 \\
Ração canina & Umedecida & $\mathrm{X}$ & $\mathrm{X}$ & $\mathrm{X}$ & $\mathrm{X}$ & $\mathrm{X}$ & $\mathrm{X}$ & $\mathrm{X}$ & 100 \\
Camundongo & Unidade & & $\mathrm{X}$ & & & $\mathrm{X}$ & & & 02 \\
Cupinzeiro & Pequeno & $\mathrm{X}$ & & & & & & & 01 \\
Cana de açúcar & $\begin{array}{l}\text { Descascada e } \\
\text { picada }\end{array}$ & $\mathrm{X}$ & & & & & & & 100 \\
\hline
\end{tabular}

Fonte: (PARQUE ECOLÓGICO DE SÃO CARLOS).

\subsubsection{Parque Zoológico Municipal Quinzinho de Barros - Sorocaba - SP}

No início das atividades dividiam o mesmo recinto dois machos e duas fêmeas (Figuras 16 e 17), onde durante o dia todos os animais compartilhavam o mesmo recinto de exposição, mas durante a noite as fêmeas eram separadas e fechadas em diferentes recintos internos (cambiamentos) para viabilizar a coleta identificada das fezes pela manhã. Após a coleta as fêmeas eram soltas no recinto de exposição. Logo nos primeiros meses de coleta os 
dois machos morreram por causas desconhecidas (laudo de necropsia inconclusivo) de acordo com a instituição mantenedora, permanecendo apenas as duas fêmeas. O esquema de coleta se manteve o mesmo, prendendo uma das fêmeas durante a noite para realizar a coleta na manhã seguinte seguida da soltura para o recinto de exposição.

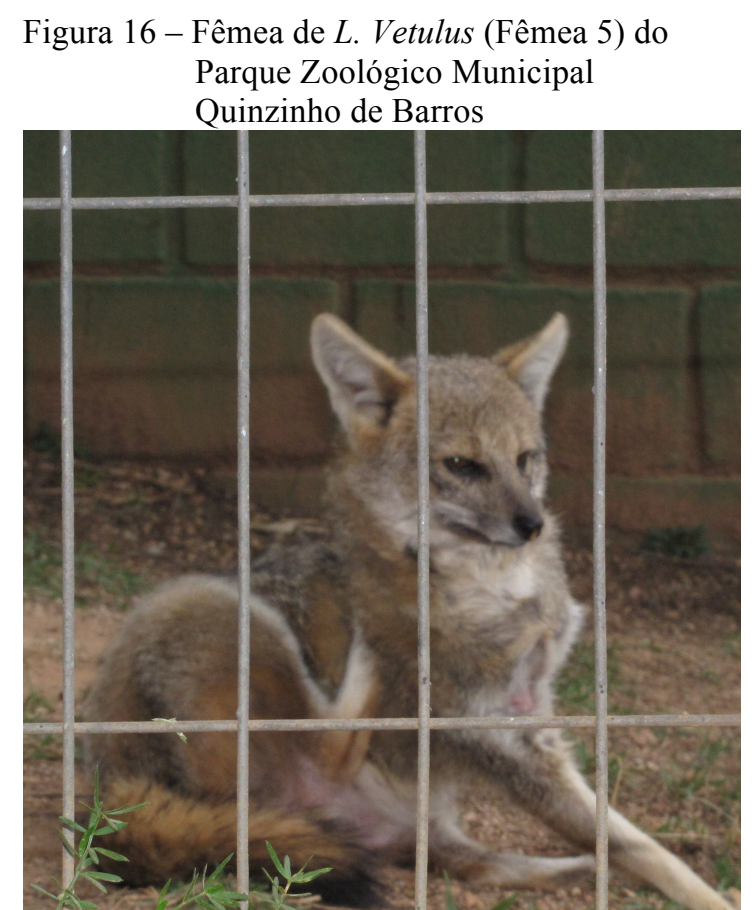

Fonte: (CANDEIAS, I. Z., 2014).

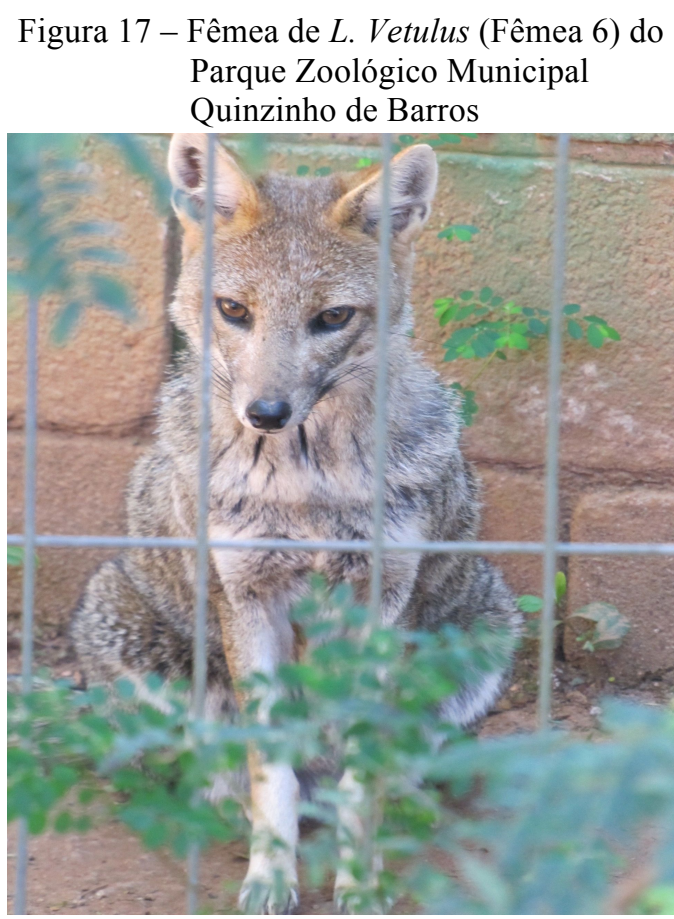

Fonte: (CANDEIAS, I. Z., 2014).

O recinto da raposa do campo mede cerca de $68 \mathrm{~m}^{2}$, sem sombreamento natural, com substrato de terra batida, capim, possui um tanque de $1 \mathrm{~m}^{2}$ e três cambiamentos de alvenaria, cobertos. Pelo menos um cambiamento fica aberto durante o dia com livre acesso dos animais, onde fica o bebedouro. A barreira do público é formada por guarda corpo de metal, tela de arame e arbustos entre a tela e o guarda corpo. Na figura 18 pode-se observar o esquema do recinto das raposas do campo na instituição. 
Figura 18 - Ilustração do recinto das L. vetulus no Parque Zoológico Municipal Quinzinho de Barros

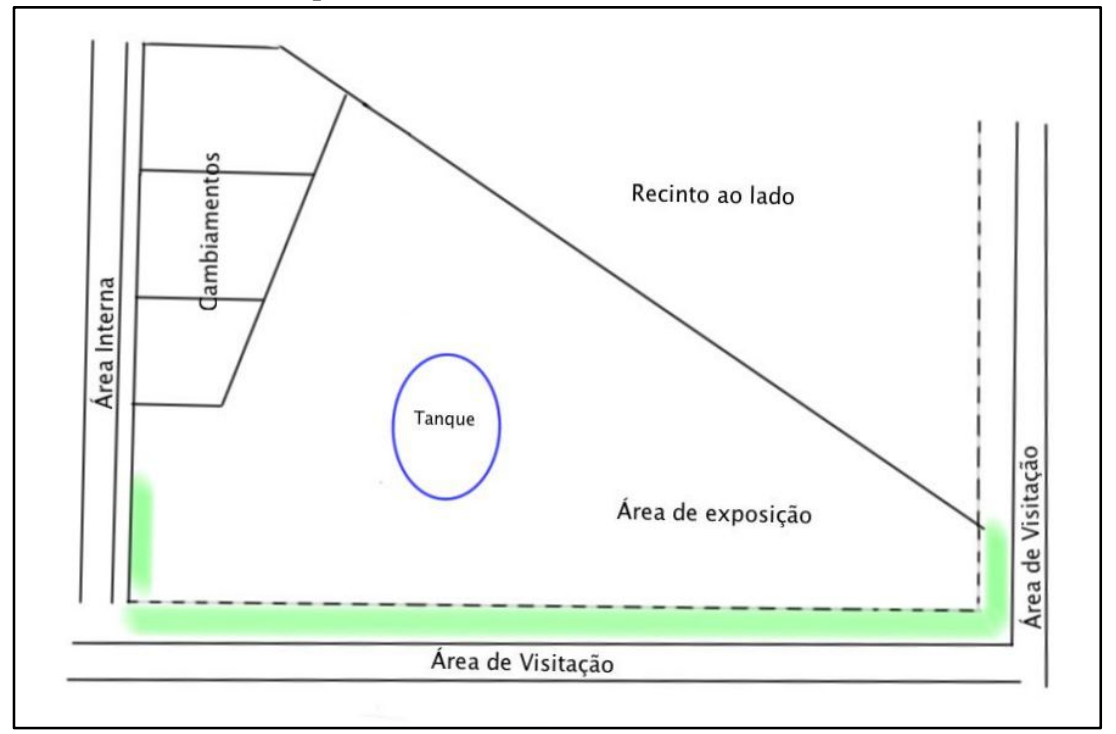

Legenda: As linhas contínuas representam paredes de alvenaria e as linhas tracejadas grade metálica; a área verde representa a vegetação em meia altura $(1 \mathrm{~m})$ entre o guarda corpo e a grade metálica.

A alimentação era fornecida uma vez ao dia, em bandejas individualizadas. A seguir a tabela 5 apresentando os itens alimentares fornecidos aos indivíduos de raposa-do-campo:

Tabela 5 - Composição da dieta oferecida aos L. vetulus no Parque Zoológico Municipal Quinzinho de Barros pela manhã

\begin{tabular}{llllllllll}
\hline Item & $2^{\mathrm{a}}$ & $3^{\mathrm{a}}$ & $4^{\mathrm{a}}$ & $5^{\mathrm{a}}$ & $6^{\mathrm{a}}$ & Sáb & Dom & Gramas & Apresentação \\
\hline Coração/ pescoço & & & & $\mathrm{X}$ & & $\mathrm{X}$ & & 50 & Seca \\
Ração de Cachorro & $\mathrm{X}$ & $\mathrm{X}$ & & $\mathrm{X}$ & & $\mathrm{X}$ & & 100 & \\
Fígado & & $\mathrm{X}$ & & & & $\mathrm{X}$ & & 50 & \\
Rim & & & $\mathrm{X}$ & & $\mathrm{X}$ & & & 50 & \\
Banana & $\mathrm{X}$ & $\mathrm{X}$ & $\mathrm{X}$ & $\mathrm{X}$ & $\mathrm{X}$ & $\mathrm{X}$ & & 150 & Picada s/casca \\
Fruta de época & $\mathrm{X}$ & & $\mathrm{X}$ & & $\mathrm{X}$ & & & 100 & Picada \\
Abacaxi & & $\mathrm{X}$ & & $\mathrm{X}$ & & $\mathrm{X}$ & & 100 & Picada s/casca \\
Melancia & & & $\mathrm{X}$ & & $\mathrm{X}$ & $\mathrm{X}$ & & 100 & Picada \\
Pintinho/ Camundongo & & & $\mathrm{X}$ & & $\mathrm{X}$ & & & 4 unid. ou $180 \mathrm{~g}$ & \\
Vitamina & & $\mathrm{X}$ & & $\mathrm{X}$ & & & & $12 \mathrm{~g}$ & 1 medida peq \\
\hline
\end{tabular}

Fonte: (PARQUE ZOOLÓGICO MUNICIPAL QUINZINHO DE BARROS). 


\subsubsection{Bosque e Zoológico Municipal Dr. Fábio de Sá Barreto - Ribeirão Preto - SP}

Essa foi a única instituição participante desse projeto na qual os animais não estavam expostos ao público. Duas fêmeas (Figuras 19 e 20) dividem um mesmo recinto interno na instituição. Como o recinto não permitia a separação dos animais para a coleta das fezes individualizada, foi necessário o uso de corante alimentar (Corante em pó Mix ${ }^{\circledR}$ ), na dieta de uma das fêmeas para poder identificar as fezes. O corante em pó foi utilizado na cor rosa, e foi administrado em todas as vésperas de coleta fecal, em um pedaço de carne dado sempre a mesma fêmea (fêmea 8) que era mais mansa. Foi utilizado cerca de 10 gramas para colorir o pedaço de carne na cor do corante.

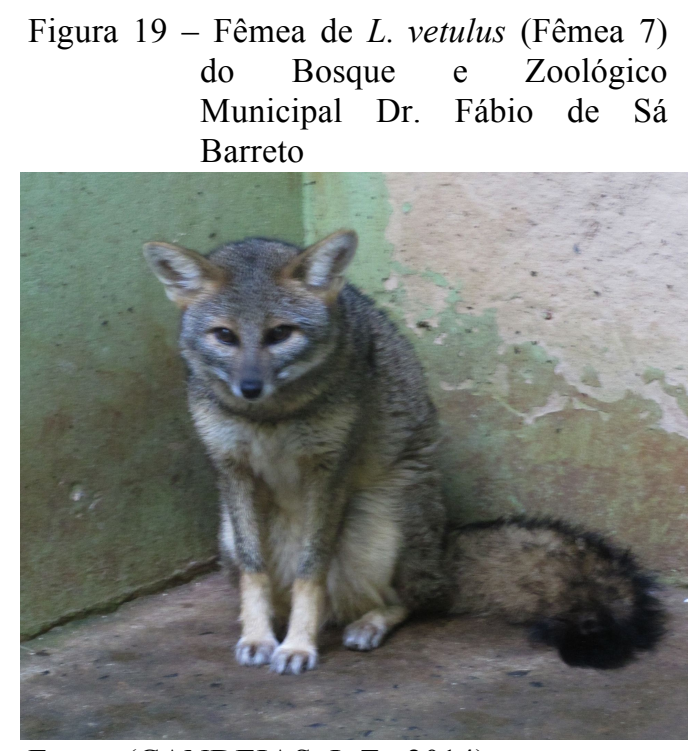

Fonte: (CANDEIAS, I. Z., 2014).
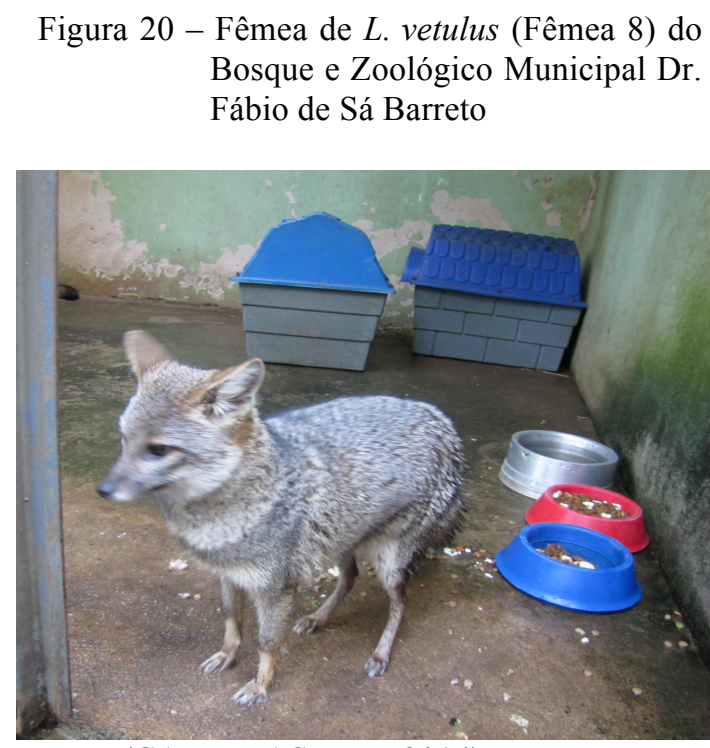

Fonte: (CANDEIAS, I. Z., 2014).

O recinto possui cerca de $10 \mathrm{~m}^{2}$, possui piso de concreto, paredes de alvenaria, não possui cambiamento ou áreas com vegetação (Figura 21), o abrigo é formado por duas caixas plásticas para cachorros domésticos. 
Figura 21 - Esquema do recinto das L. vetulus no Bosque e Zoológico Municipal Dr. Fábio de Sá Barreto

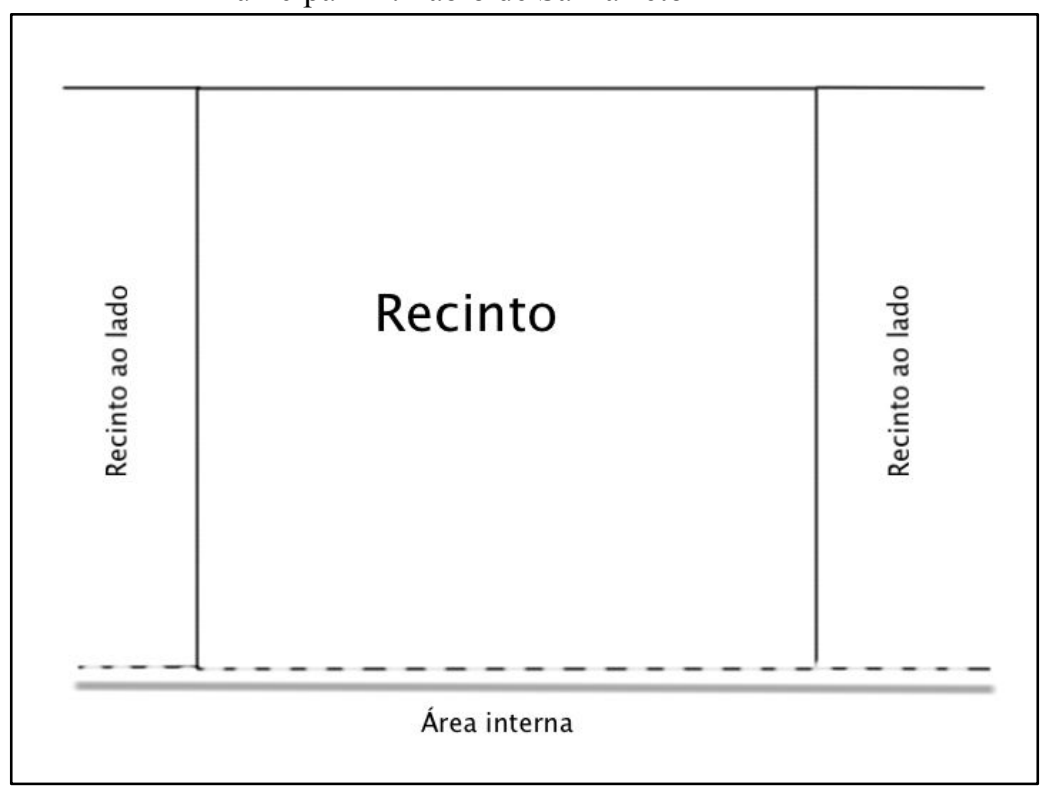

Legenda: As linhas contínuas representam paredes de alvenaria e as linhas tracejadas grade metálica.

Tabela de alimentação - Apesar de diversos pedidos, a instituição não forneceu os dados sobre a alimentação dos animais, mas durante as coletas foi possível observar que a alimentação era formada por ração de cachorro, carne bovina crua e frutas picadas.

\subsection{COLETA DAS AMOSTRAS}

A coleta das amostras foi realizada pelas instituições mantenedoras dos animais, para isso, antes do início das coletas foram fornecidos às instituições os materiais de coleta, armazenamento e organização das amostras, assim como os funcionários foram instruídos a coletar da melhor maneira possível. Na figura 22 podemos observar os materiais entregue às instituições. 
Figura 22 - Material entregue as instituições para a coleta de amostras

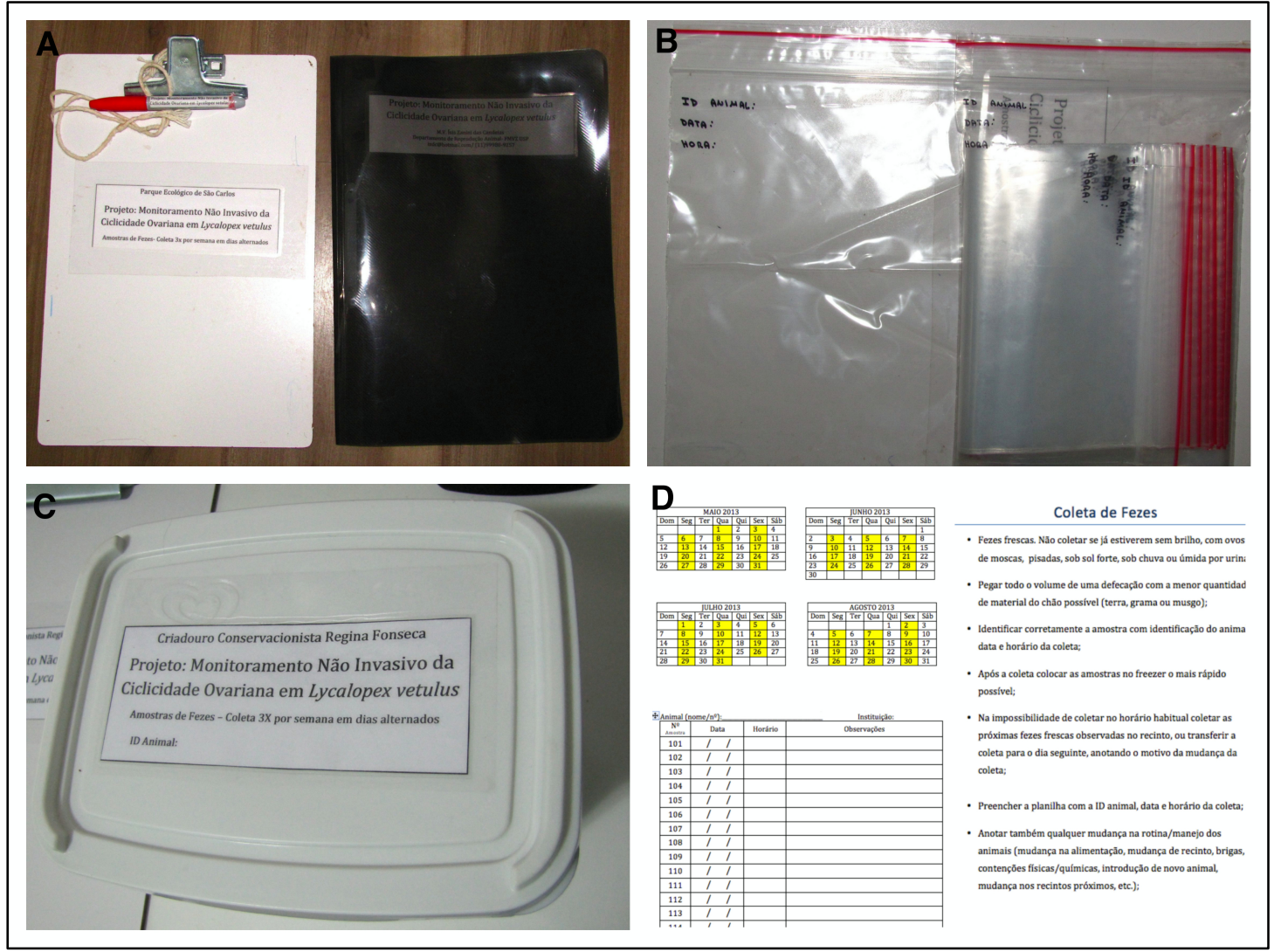

Legenda: A: Prancheta e caneta permanente para anotações e pasta de informações; B: saquinhos tipo zip lock para coletar e armazenar as fezes; C: pote para armazenar as fezes no freezer das instituições; D: Conteúdo da pasta: calendário de coleta, instruções para coleta e controle geral das amostras.

As amostras fecais frescas foram colhidas no período da manhã, de fêmeas de Lycalopex vetulus, três vezes por semana, durante 12 meses. A coleta foi realizada diretamente do recinto, contendo a menor quantidade de substrato do recinto possível, com a ajuda de um saco plástico. As amostras foram identificadas com o número do animal, data e horário da coleta e mantidas no freezer $-20^{\circ} \mathrm{C}$ da instituição até a realização do transporte para o laboratório de Dosagens Hormonais da Faculdade de Medicina Veterinária e Zootecnia da Universidade de São Paulo, onde foram realizadas as extrações.

Uma vez ao mês foram feitas visitas a todas as instituições para entregar mais material de coleta e buscar as amostras já coletadas. 


\subsection{VALIDAÇÃO FISIOLÓGICA DOS ENSAIOS}

Após o final dos 12 meses de coletas regulares das fezes, foi realizada a validação fisiológica dos ensaios para dosagem de metabolitos fecais dos esteróides. Para esta validação, foram utilizadas quatro fêmeas, duas presentes no Zoológico de Piracicaba, em Piracicaba - SP e duas fêmeas no Parque Zoológico Municipal Quinzinho de Barros em Sorocaba-SP.

Foram coletadas fezes frescas por sete dias consecutivos, e após a segunda coleta foi administrado 0,0084mg de acetato de buserelina, análogo sintético do GnRH (Sincroforte ${ }^{\circledR}$ Ourofino) por via intramuscular. Após esta aplicação, foram coletadas amostras de mais cinco dias, sempre pela manhã.

A validação fisiológica para os glicocorticoides foi realizada por CASTELDA, S. .

\subsection{EXTRAÇÃO DOS METABÓLITOS}

As extrações dos metabólitos foram realizadas segundo técnica preconizada por Palme; Möstl (1996) adaptado pelo LDH-FMVZ/USP, como segue:

$-0,2 \mathrm{~g}$ de fezes secas (liofilizadas) foram pesadas e transferidas para tubo de ensaio devidamente identificado;

-Acrescidos $5 \mathrm{ml}$ de metanol com concentração 80\% (80\% de metanol e 20\% de água tipo I);

-Tubos foram colocados em aparelho multivortex (VWRScientificProducts, VX-2500) por 15 minutos para homogeneização;

-Em seguida, centrifugados por 20 minutos a 2200 rpm (Universal 320 HettichZentrifugen);

\footnotetext{
${ }^{1}$ CASTELDA, S. - Evaluating Human Threats to Three Canid Species of the Brazilian Cerrado - Ph.D. dissertation from George Mason University. Não publicado.
} 
$-1,0 \mathrm{ml}$ do sobrenadante (extrato fecal) foi pipetado e transferido para tubo de plástico cônico com volume de 2,0ml (eppendorf), identificado com o número da amostra; e em seguida evaporados.

-Os tubos secos foram selados e armazenados em freezer $-20^{0}$.

Na figura 23 estão representados os equipamentos utilizados nessa etapa.

As amostras assim preparadas foram levadas para o Instituto Smithsonian de Biologia da Conservação $(S C B I)$, Virginia - EUA, onde foram dosadas.

Figura 23 - Equipamentos utilizados na extração das amostras fecais no Laboratório de Dosagens Hormonais da Faculdade de Medicina Veterinária e Zootecnia da Universidade de São Paulo

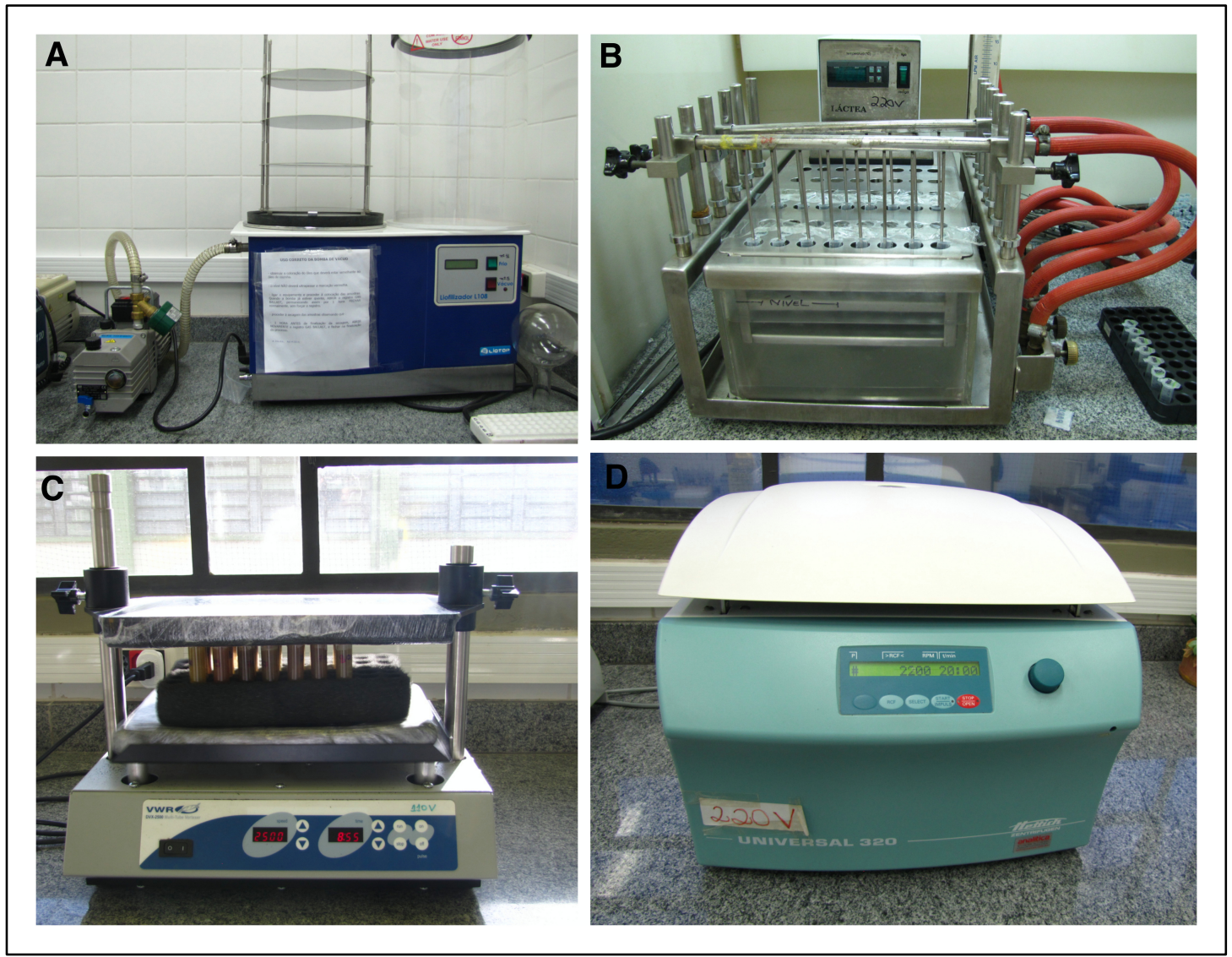

Legenda: A: Liofilizador utilizado para retirar a água das amostras fecais. B: Equipamento para secagem das amostras durante o processo de extração. C: Vórtex utilizado para misturar a amostra e o solvente. D: Centrífuga utilizada para separar o sobrenadante. 


\subsection{DOSAGEM POR ENZIMAIMUNOENSAIO}

No Instituto Smithsonian de Biologia da Conservação (SCBI), as amostras foram ressuspendidas em 1,0ml da solução buffer de diluição. Para as dosagens foi utilizado um novo ensaio comercial adotado pelo laboratório, o Arbor Assays ${ }^{\circledR}$.

Os anticorpos utilizados foram anti-progesterona CL425 monoclonal nos ensaios de progesterona, E1 Glucoronide policlonal R522-2b nos ensaios de conjugado de estrona e R0006 nos ensaios de corticosterona.

As diluições utilizadas foram de 1:50.000, 1:40.000 e 1:60.000 para os anticorpos CL425, R522-2b e R0006, respectivamente. Já para os HRPs, foram de 1:75.000, 1:80.000 e 1:45.000 para os hormônios progesterona, conjugado de estrona e corticosterona respectivamente.

As microplacas usadas foram marcadas previamente com anticorpo no próprio Instituto Smithsonian. Para as dosagens dos metabolitos fecais de progesterona foram usadas placas pré-marcadas com anticorpo anti-mouse e anti-rabbit para dosagens dos metabólitos de estradiol e corticosterona.

As placas foram mantidas em temperatura ambiente cerca de 30 minutos antes da utilização e adicionados $50 \mu 1$ de solução padrão, amostra ou controle por poço em duplicata. Depois foram adicionados $25 \mu 1 /$ poço de HRP e $25 \mu 1 /$ poço de Anticorpo (exceto nos poços representativos do Branco), as microplacas foram seladas e incubadas no agitador por duas horas a temperatura ambiente para metabolitos de progesterona e estradiol, e por uma hora para metabolitos de glicocorticoides.

Após a incubação, as microplacas foram lavadas cinco vezes com solução de lavagem, secas e adicionado $100 \mu 1$ poço de substrato cromógeno (TMB substrato). A reação cromógena foi parada com $100 \mu 1$ poço de solução STOP $\left(\mathrm{H}_{2} \mathrm{SO}_{4} 96 \%\right.$ : 10\%) depois de 30 minutos para metabolitos de progesterona, 6 minutos para metabolitos de estradiol e 30 minutos para metabolitos de glicocorticoides.

A densidade óptica foi medida em uma leitora automática Dynex MRX, Dynex Technologies - VA, utilizando o filtro de 450nm (Figura 24). 
Figura 24 - Leitora óptica MRX utilizada na leitura das amostras (Dynex MRX; Dynex Technologies, VA)

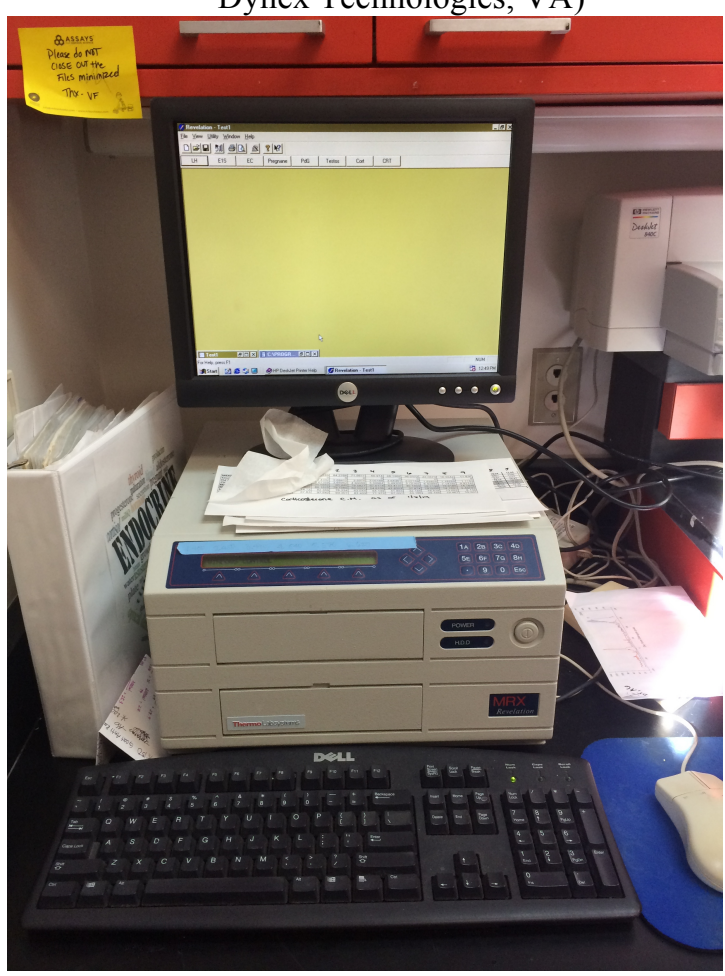

Todas as amostras, controles e padrões foram analisados em duplicata.

Os coeficientes de variação $(\mathrm{CV})$ intra e inter-ensaios $(n=127)$ abaixo de $10 \%$.

A seguir na figura 25 o modelo de mapa das microplacas utilizado e na figura 26 três microplacas em diferentes estágios de evolução.

Figura 25 - Mapa das microplacas utilizado nos enzimaimunoensaio

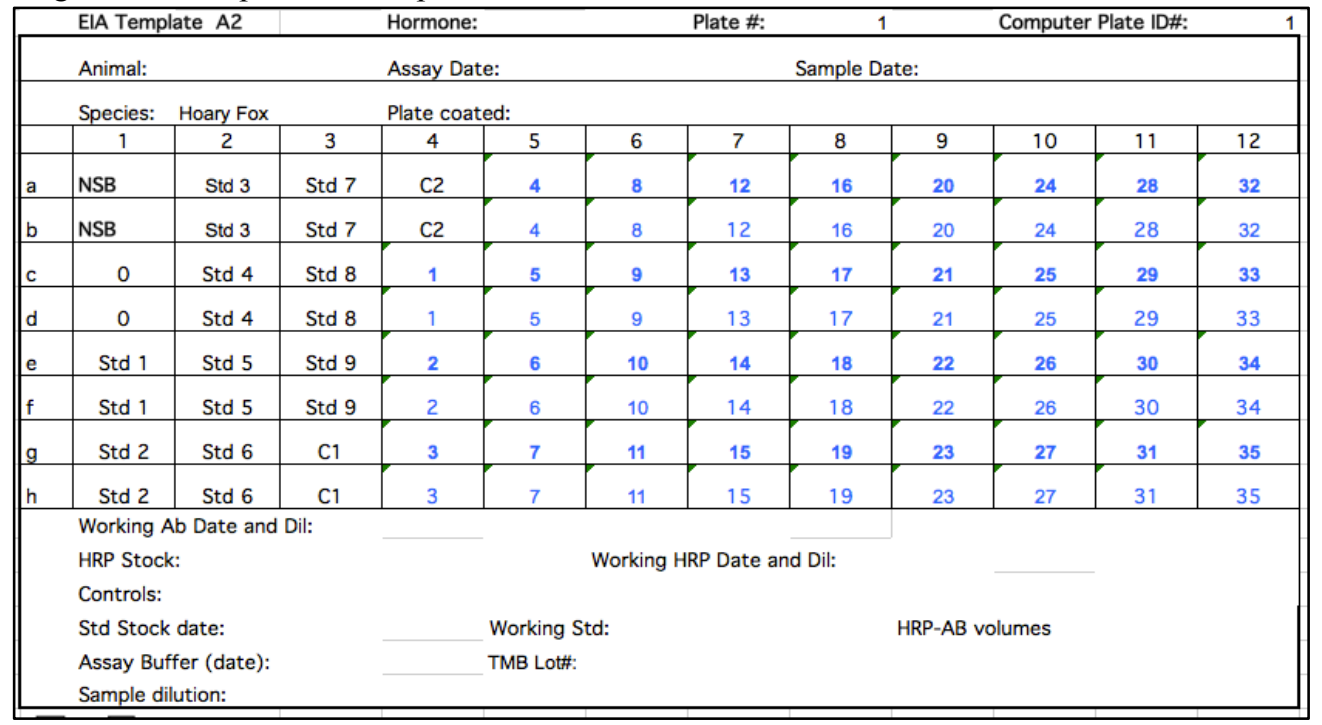


Figura 26 - Microplacas de enzimaimunoensaio em diferentes estágios de desenvolvimento

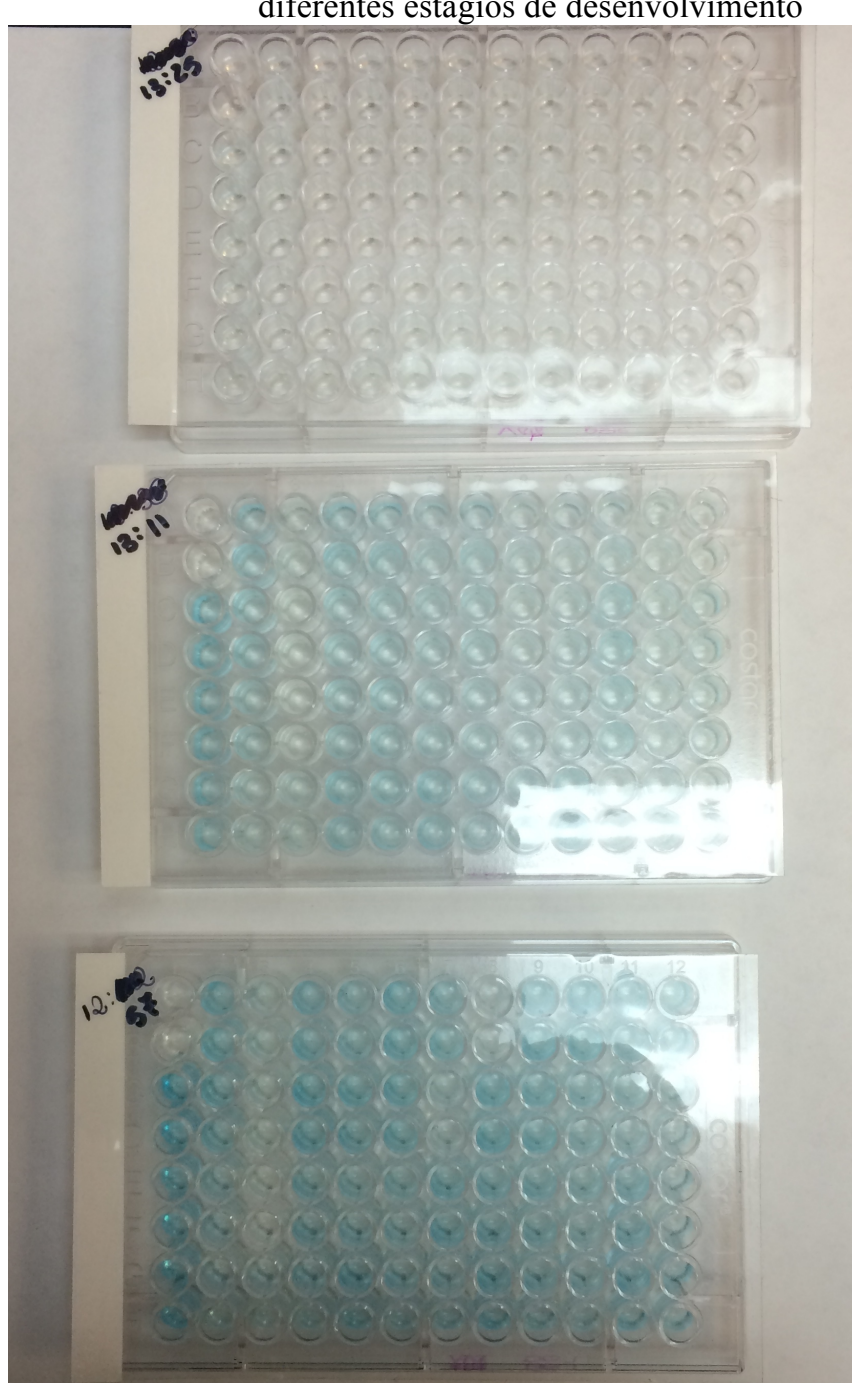

\subsection{PARALELISMO}

Para cada hormônio mensurado foi realizado o teste de paralelismo. O teste verifica se o anticorpo utilizado consegue se ligar ao metabólito estudado, na matriz fecal da mesma forma com que se liga ao padrão. Esse teste também ajuda a determinar a diluição da amostra a ser usada para o ensaio.

Um pool de amostras de diferentes períodos do ano, de todas as fêmeas foi diluído de forma serial (amostra, 1:2, 1:4, 1:8, 1:16, 1:32, 1:64, etc.) e dosado para cada grupo de metabólitos (progesterona, conjugado de estrona e corticosterona) de acordo com o protocolo descrito acima. 
Os resultados das porcentagem de ligação das amostras foram plotados juntamente com as porcentagens obtidas de diluições semelhantes do padrão, produzindo duas curvas: a curva padrão e a curva das amostras e verificada a existência de paralelismo entre as duas curvas. A mais acurada diluição para rodar as amostras é aproximadamente com $50 \%$ de ligação.

\subsection{TESTE DE ACURÁCIA}

O teste de acurácia foi realizado de acordo com o proposto por Brown, 2008.

O teste de acurácia ou recuperação testa a potencial interferência causada por substâncias contidas na amostra biológica que são independentes de ligação específica antígeno-anticorpo. Esse teste indica o grau que a mensuração da concentração corresponde a real concentração da substância.

Um pool de amostras com baixas concentrações hormonais, foi adicionado em quantidades iguais a cada padrão, exceto no padrão mais baixo. Essas amostras foram dosadas de acordo com o protocolo já descrito. O pool de amostras também foi dosado sem a adição do padrão para determinar a quantidade de hormônio endógeno presente. Esse valor foi subtraído de cada amostra padrão misturada com o pool.

Os resultados foram adicionados em uma tabela e calculados os valores de Quantidade esperada (concentração do padrão adicionado com pool/2), Quantidade observada (concentração observada nos resultados do ensaio - dosagem do pool), \% de recuperação [(concentração observada / concentração esperada)*100] e feita uma análise de regressão linear. Desvios maiores ou menores a 1 sugerem uma sobre ou sub estimação da concentração hormonal, respectivamente.

\subsection{HPLC - CROMATOGRAFIA LÍQUIDA DE ALTA PERFORMANCE}


A cromatografia líquida de alta performance é uma técnica de separação usada para identificar metabólitos específicos ou componentes em uma dada amostra. HPLC separa a amostra em frações, e cada fração é analisada por reação cruzada através do ensaio utilizado para dosar as amostras regulares. A separação é realizada quando duas fases são colocadas em contato, uma fase estacionária (a coluna) e outra móvel (líquido). O pool de amostras é forçado através da coluna por pressão e passa por uma série de interações entre a fase estacionária e móvel. As interações exploram as diferenças nas propriedades químicas ou físicas dos componentes com a amostra. Essas diferenças governam a taxa de migração dos componentes individuais sob a influência da fase móvel se movendo pela coluna. Componentes separados aumentam a interação com a fase estacionária. Os componentes com menor resistência saem primeiro, o material mais fortemente retido sai por último. A seleção do método de HPLC mais apropriado é feita de acordo com as propriedades da amostra como peso molecular, solubilidade e polaridade.

O método mais comum para separação de esteróides é cromatografia de fase reversa e é baseada na polaridade [uma fase estacionária não polar (coluna feita com hidrocarbonos) e uma fase polar móvel (ex. Metanol, água e etanol)]. Os componentes da amostras são atraídos para a superfície do adsorvente (fase sólida) com diferentes forças. Amostras não polares são atraídas para a fase estacionária e são retidas, o componente mais polar é liberado primeiro. Conforme o gradiente da fase móvel é ajustado pelo tempo, os componentes são separados. Conforme a polaridade da fase móvel aumenta, as amostras não polares começam a sair da coluna.

\subsubsection{Protocolo de HPLC - Preparação da amostra}

O propósito da preparação da amostra para HPLC é obter uma amostra com alta concentração do hormônio a ser investigado pela combinação de amostras com massa de hormônio elevado. Por exemplo, se necessita buscar estrógenos na urina, porções de várias amostras coletadas durante o estro devem ser combinadas para representar uma amostra com nível elevado de estrógenos. 
O número de amostras combinadas para fazer uma amostra para HPLC é altamente dependente da espécie e da qualidade da amostra disponível. No presente estudo foram utilizadas 10 amostras, de todos os indivíduos.

A combinação de amostras $(500 \mu \mathrm{l})$ foi seca, ressuspendida em $1 \mathrm{ml}$ de $\mathrm{MeOH}$ e realizado o processo de secagem novamente, permanecendo congelada até o processamento.

\subsubsection{Filtração}

O pool de amostras foi ressuspendido em 500 $\mu$ l de PBS, colocado no vortex e sonicador para retirar qualquer resquício de amostra da parede do tubo. Com a ajuda de uma seringa, $3 \mathrm{ml}$ de $\mathrm{MeOH}$ foi passado pelo filtro próprio para preparação de amostras para o HPLC, seguido de $3 \mathrm{ml}$ de $\mathrm{dH} 2 \mathrm{O}$.

A amostra foi pipetada dentro de uma seringa de $3 \mathrm{ml}$, que foi conectada ao filtro e a amostra passou pelo filtro naturalmente, sem pressão exercida. Após, $5 \mathrm{ml}$ de dH2O foi passado pelo filtro e por último $5 \mathrm{ml}$ de $\mathrm{MeOH}$ foi passado pelo filtro e a fração recolhida para a análise por HPLC. O esquema dessa etapa pode ser visualizado na figura 27.

A fração recolhida foi seca e armazenada em freezer $-20^{\circ} \mathrm{C}$ até a sua utilização.

Figura 27 - Ilustração da filtragem da amostra previamente ao processo de HPLC

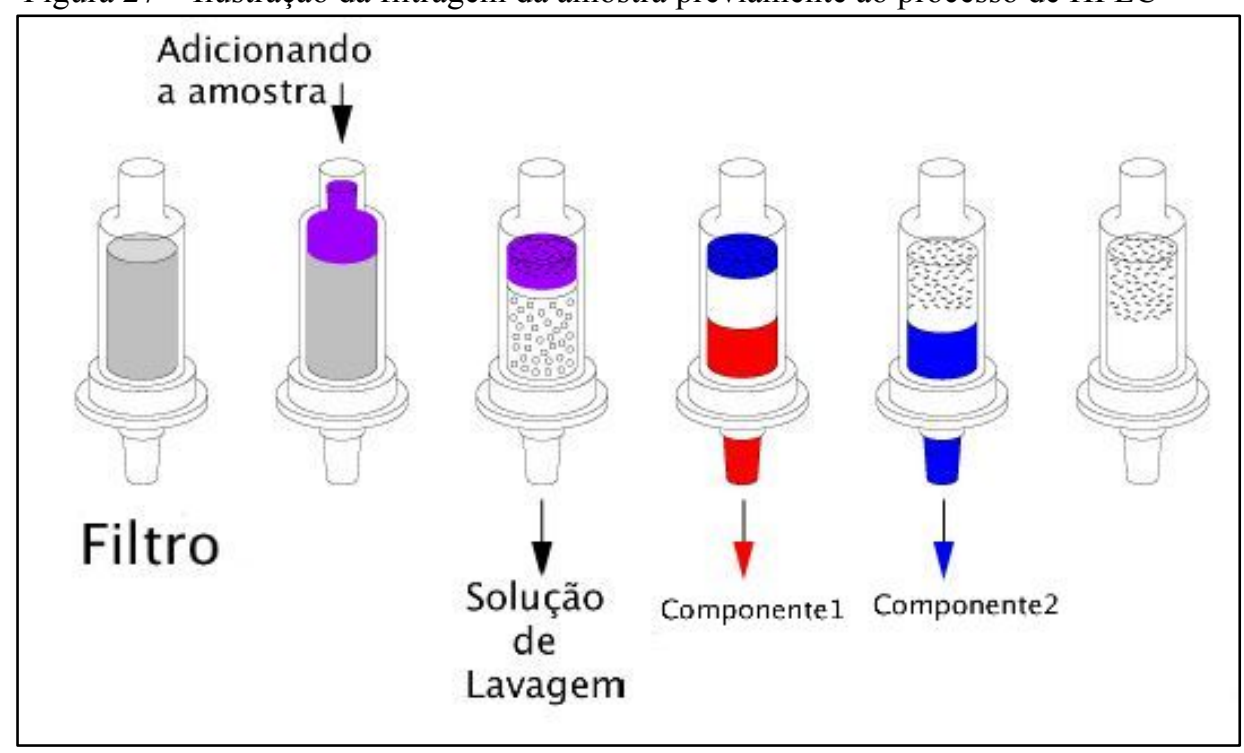

Fonte: (HTTP://WWW.WATERS.COM - ACESSO EM 12/04/2014). 


\subsubsection{Adicionando marcador radioativo na amostra}

Foram realizados dois HPLC, uma para progesterona, onde foi adicionado $900 \mu \mathrm{l}$ de progesterona radioativa na amostra. E outro para metabólitos de estradiol, onde foram adicionados estrona, estradiol e tri-sulfato de estrona, $300 \mu$ de cada hormônio.

Após adicionar o marcador radioativo Trício, a amostra foi seca e ressuspendida em $300 \mu \mathrm{lde} \mathrm{MeOH}$. A seguir a amostra foi injetada no aparelho de HPLC (Figura 28).

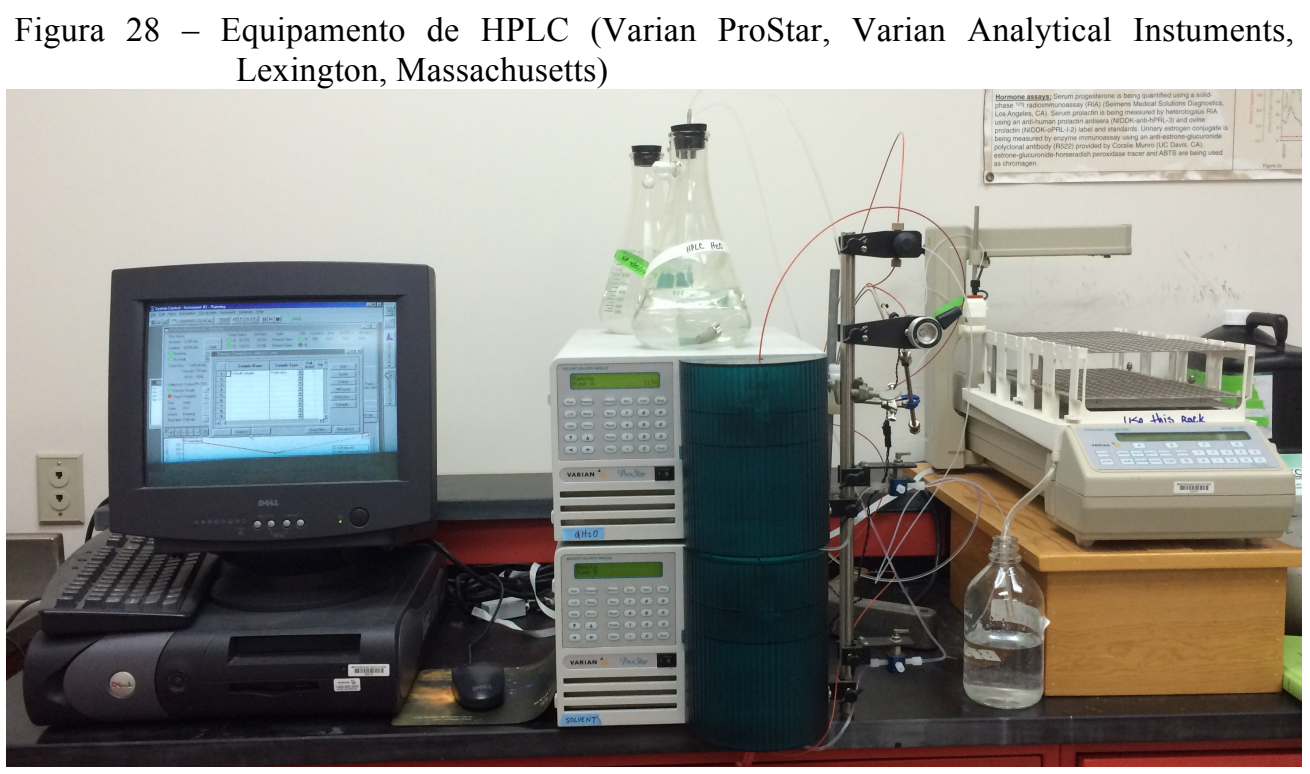

\subsubsection{Contagem Radioativa}

Após a separação, as frações tiveram $100 \mu$ aliquotados em frascos de cintilação e foi adicionado $3 \mathrm{ml}$ de líquido de cintilação em cada frasco. As amostras foram tampadas, agitadas e deixadas por 20 minutos na bancada, antes da contagem no contador beta (Figura 29).

Os resultados finais de DPM por fração foram colocados em uma planilha e calculada contagem por fração, como no exemplo a seguir na tabela 6 . 
Tabela 6 - Exemplo do cálculo de DPM final por fração

\begin{tabular}{|c|c|c|c|c|c|c|}
\hline 1 & A & $\mathrm{B}$ & $\mathrm{C}$ & $\mathrm{D}$ & $\mathrm{E}$ & $\mathrm{F}$ \\
\hline 2 & \multicolumn{6}{|c|}{ Branco $=9,028$} \\
\hline 3 & \multicolumn{6}{|c|}{ Radioatividade $-\mathrm{H} 3$} \\
\hline 4 & $\mathrm{~N}^{\mathrm{o}}$ Fração & $\mathrm{DPM} / 100 \mu 1$ & $\begin{array}{l}\text { DPM - } \\
\text { Branco }\end{array}$ & $\mathrm{DPM} / \mu \mathrm{l}$ & $\begin{array}{c}\text { Remoção dos } \\
\text { negativos }\end{array}$ & $\begin{array}{l}\text { DPM final } \\
\text { (cpm/ml= } \\
\text { cpm/fração) }\end{array}$ \\
\hline 5 & 1 & 10,18 & 1,152 & 0,01152 & 0,01152 & 11,52 \\
\hline
\end{tabular}

Figura 29 - Contador de Radioatividade utilizado no teste após a separação de alíquotas no HPLC

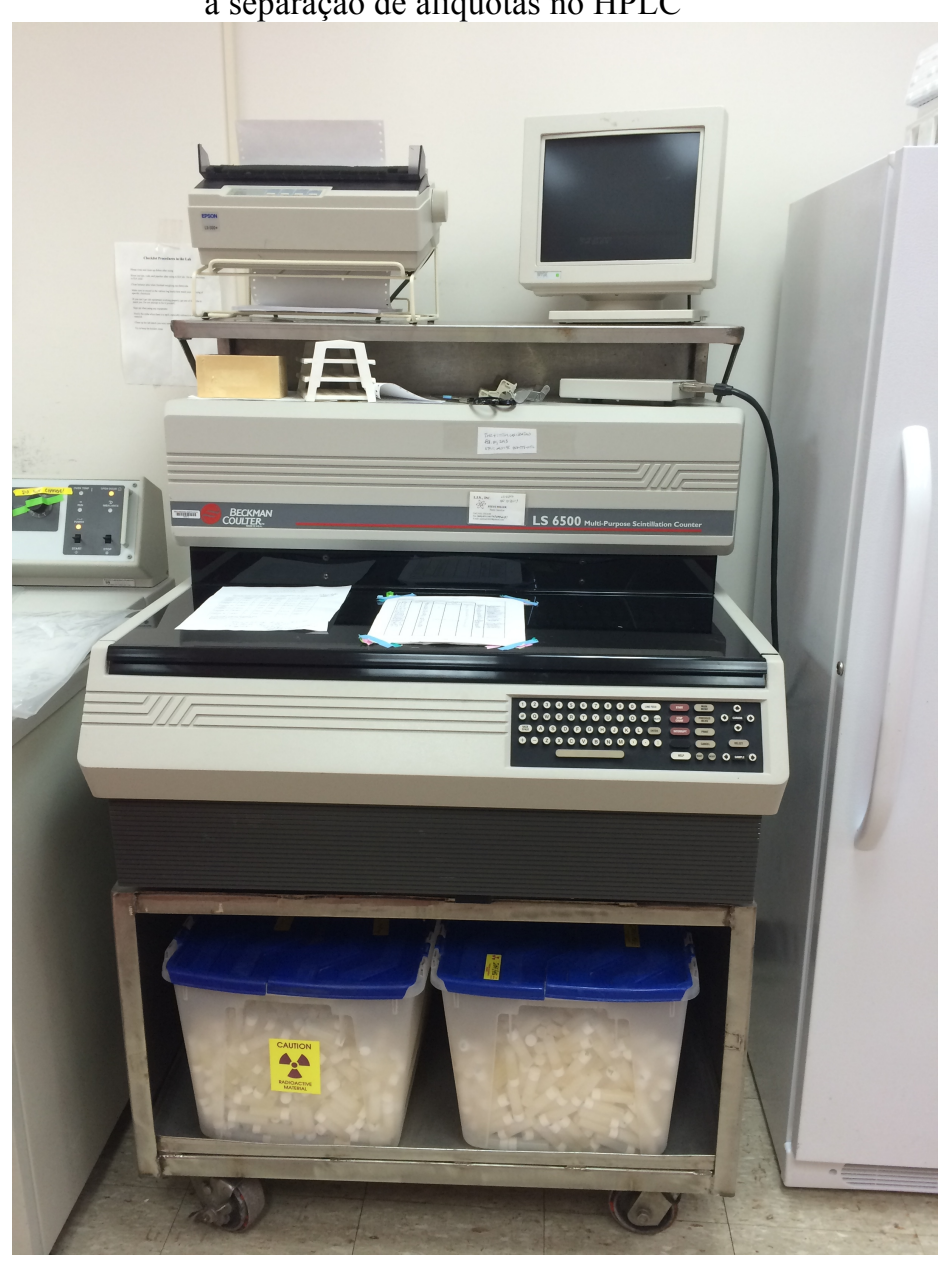

\subsubsection{Concentração Hormonal}

Após a retirada de $100 \mu 1$ de cada fração para a contagem radioativa, as frações foram secas, ressuspendidas com $125 \mu \mathrm{l}$ de buffer de diluição e dosadas para cada hormônio 
(conjugado de estrona e progesterona) com o mesmo protocolo já descrito anteriormente de enzimaimunoensaio, com o qual foram dosadas todas as amostras do estudo.

Os resultados da leitura do enzimaimunoensaio foi convertido para $\mathrm{ng} / \mathrm{ml}$ (A ng/ml); calculada a concentração pelo volume ressuspendido $(\mathrm{A} \mathrm{ng} / \mathrm{ml} * 0.125 \mathrm{ml}=\mathrm{B})$; calculada a concentração em $900 \mu 1(\mathrm{~B} \mathrm{ng} / 900 \mu \mathrm{l}=\mathrm{C} \mathrm{ng} / \mu \mathrm{l})$; e por último calculada a concentração total da fração $((\mathrm{C} \mathrm{ng} / \mu \mathrm{l} / 0,9) * 1000=\mathrm{D} \mathrm{ng} / \mathrm{ml})$.

\subsubsection{Análise dos dados do HPLC}

O resultado foi plotado em gráficos, o DPM final e a concentração hormonal por fração e o número da fração. Os picos radioativos foram usados para identificar a constituição dos picos imunoativos. Embora nem todos os picos possam ser identificados, os hormônios que possuem maior reatividade cruzada com o ensaio utilizado devem ser mais proeminente e identificados.

\subsection{ANÁLISE ESTATÍSTICA}

Os valores basais de cada hormônio, para cada indivíduo foram calculados através de um processo interativo, onde os valores altos (superiores a média mais uma vez e meia o desvio padrão) foram excluídos.

Os picos individuais dos metabólitos fecais para cada hormônios foram obtidos a partir da exclusão seriada dos valores que excedessem a média $+1,5$ desvios-padrões conforme proposto por Brown, Terio e Graham (1996).

Os dados obtidos foram analisados através do programa SAS System for Windows 9.3 (SAS, 2000).

Através do aplicativo Guided Data Analisys, os dados foram testados quanto à normalidade dos resíduos (distribuição normal) e homogeneidade das variâncias. Caso não 
obedecessem a estas premissas, foram transformados (logaritmo na base 10 - Log10X; Raiz quadrada - RQ X; Quadrado - X2) e se a normalidade não fosse obtida, empregava-se, então, o procedimento NPAR1WAY de análise de variância não paramétrica. Na avaliação do efeito do tempo nas variáveis resposta, foram utilizados os testes LSD (Least Significant Difference; comparações múltiplas) e teste de Wilcoxon dois a dois para variáveis não paramétricas.

Para descrição dos resultados, foram empregadas as médias e seus respectivos erros padrões (média \pm erro padrão da média) dos dados originais.

O nível de significância utilizado para rejeitar H0 (hipótese de nulidade) foi de 5\%, isto é, para um nível de significância menor que 0,05 , considerou-se que ocorreram diferenças estatísticas entre os tratamentos com melatonina.

As variáveis concentrações de metabólitos fecais de estradiol e concentrações dos metabólitos fecais de glicocorticoides não obedeceram às premissas estatísticas sendo necessária a transformação para logaritmo na base 10 . 


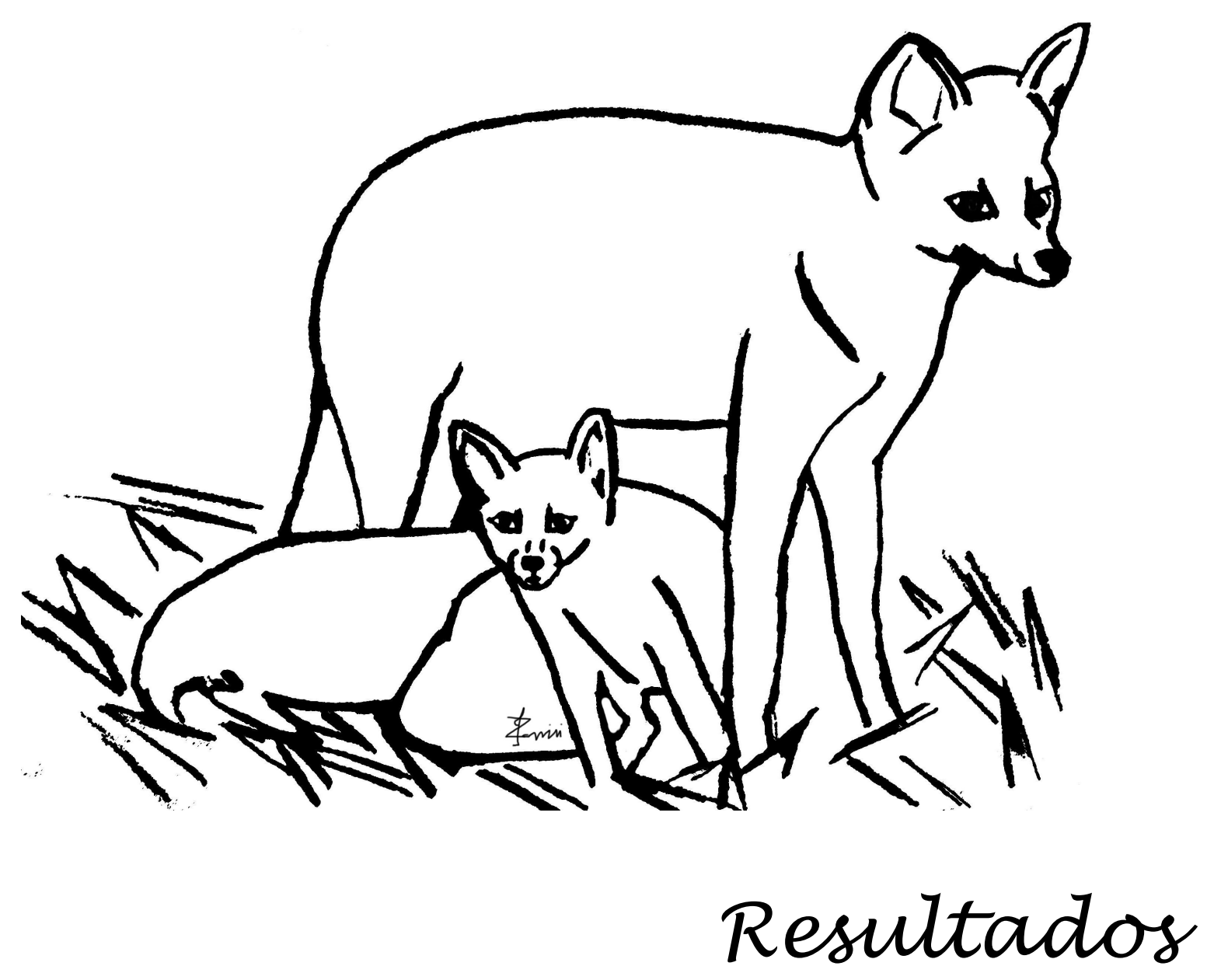




\section{RESULTADOS}

Ao longo de 12 meses foram coletadas um total de 1091 amostras fecais, distribuídas conforme a tabela 7 abaixo:

Tabela 7 - Número de amostras de fezes coletadas mensalmente de cada indivíduo

\begin{tabular}{|c|c|c|c|c|c|c|c|c|c|c|c|c|c|c|c|}
\hline \multicolumn{10}{|c|}{ Amostras de fezes coletadas } \\
\hline & \multicolumn{10}{|c|}{2012} & \multicolumn{7}{c|}{2013} & Mai \\
\hline Fêmea & Set & Out & Nov & Dez & Jan & Fev & Mar & Abr & Mai & Jun & Jul & Ago & Set & Out & Total \\
\hline 1 & 5 & 13 & 13 & 10 & 13 & 8 & 9 & 12 & 9 & 12 & 12 & 13 & 12 & 2 & 143 \\
\hline 2 & 6 & 11 & 8 & 7 & 6 & 13 & 12 & 13 & 11 & 12 & 14 & 12 & 13 & 2 & 140 \\
\hline 3 & 6 & 13 & 8 & 7 & 6 & 13 & 12 & 13 & 11 & 12 & 15 & 11 & 13 & 2 & 142 \\
\hline 4 & 6 & 14 & 13 & 13 & 13 & 12 & 14 & 12 & 12 & 11 & 9 & 12 & 13 & 6 & 160 \\
\hline 5 & 6 & 12 & 13 & 13 & 13 & 12 & 12 & 12 & 11 & 13 & 13 & 14 & 11 & 8 & 163 \\
\hline 6 & 6 & 12 & 13 & 13 & 14 & 12 & 13 & 13 & 12 & 15 & 12 & 13 & 11 & 7 & 166 \\
\hline 7 & 6 & 10 & 8 & 8 & 5 & 8 & 10 & 10 & 11 & 5 & 3 & 1 & 3 & 0 & 88 \\
\hline 8 & 6 & 10 & 8 & 8 & 6 & 9 & 10 & 10 & 10 & 5 & 3 & 1 & 3 & 0 & 89 \\
\hline Total & 47 & 95 & 84 & 79 & 76 & 87 & 92 & 95 & 87 & 85 & 81 & 77 & 79 & 27 & 1091 \\
\hline
\end{tabular}

\subsection{VALIDAÇÃO FISIOLÓGICA}

Os resultados das validações fisiológicas realizadas após o término das coletas regulares em quatro fêmeas (Fêmeas 2, 3, 5 e 6) estão representados nos gráficos de 1 a 4 a seguir. 
Gráfico 1 - Validação Fisiológica da Fêmea 2

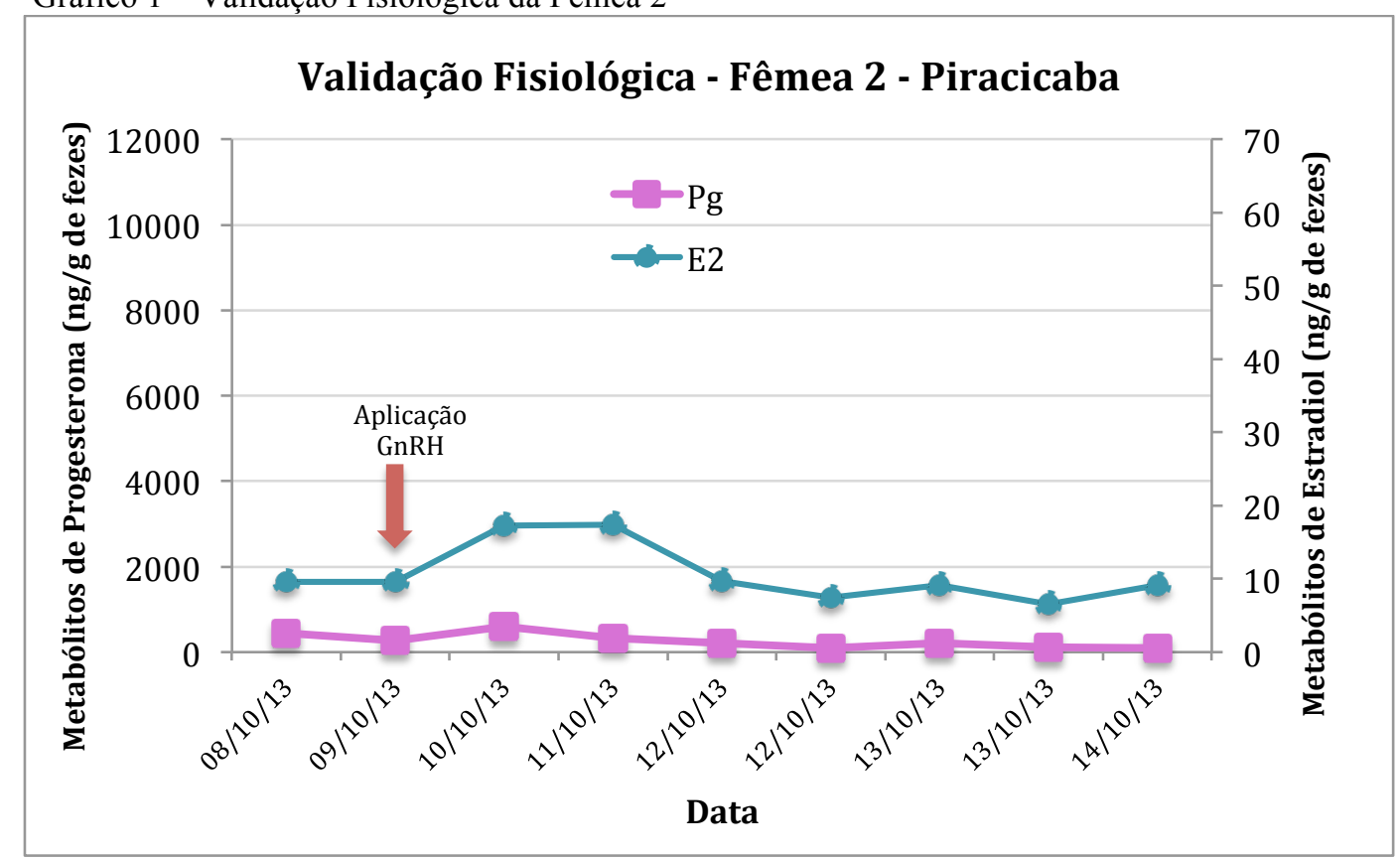

Legenda: A seta vermelha indica a aplicação de GnRH.

Gráfico 2 - Validação Fisiológica da Fêmea 3

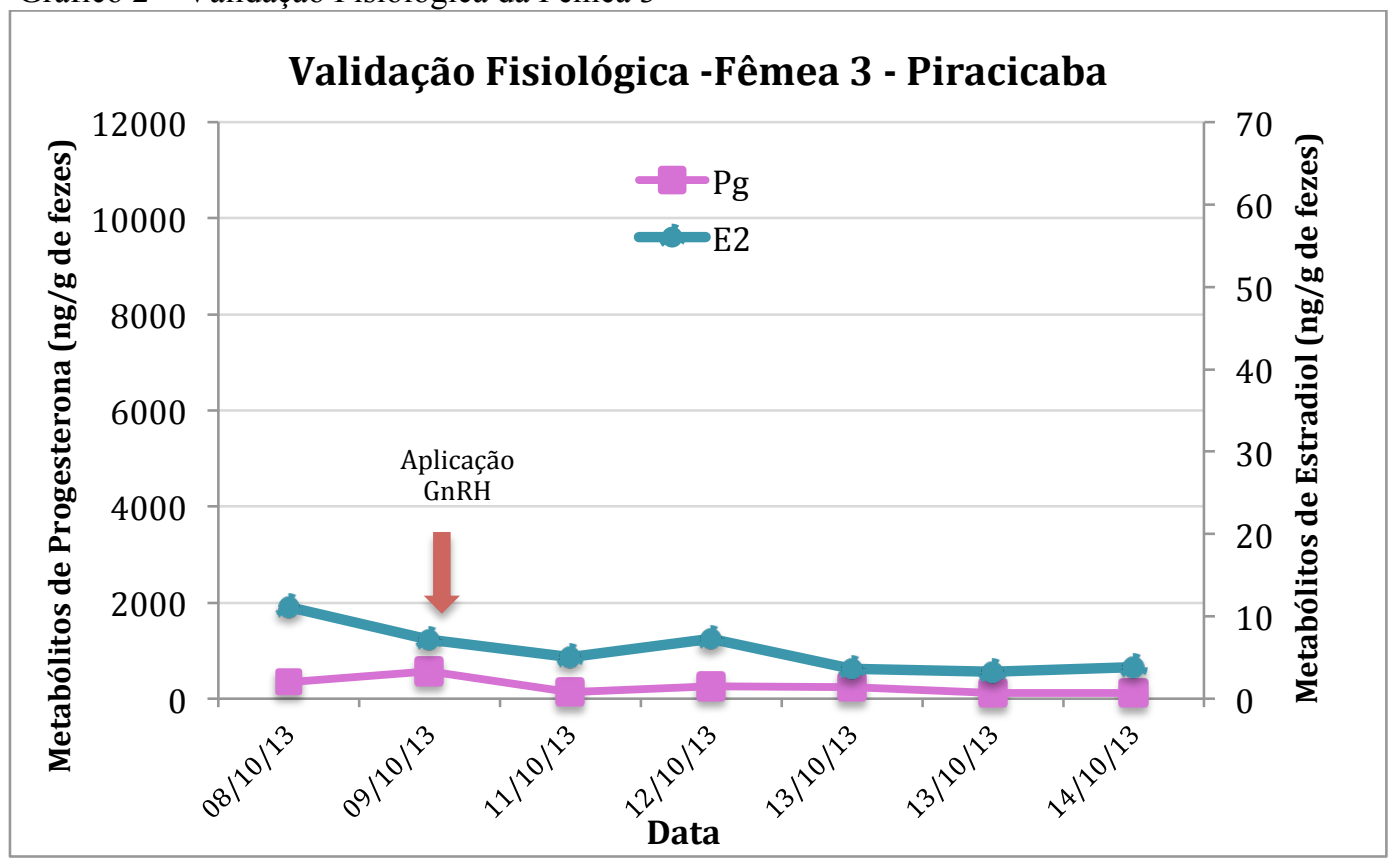

Legenda: A seta vermelha indica a aplicação de $\mathrm{GnRH}$. 
Gráfico 3 - Validação Fisiológica da Fêmea 5

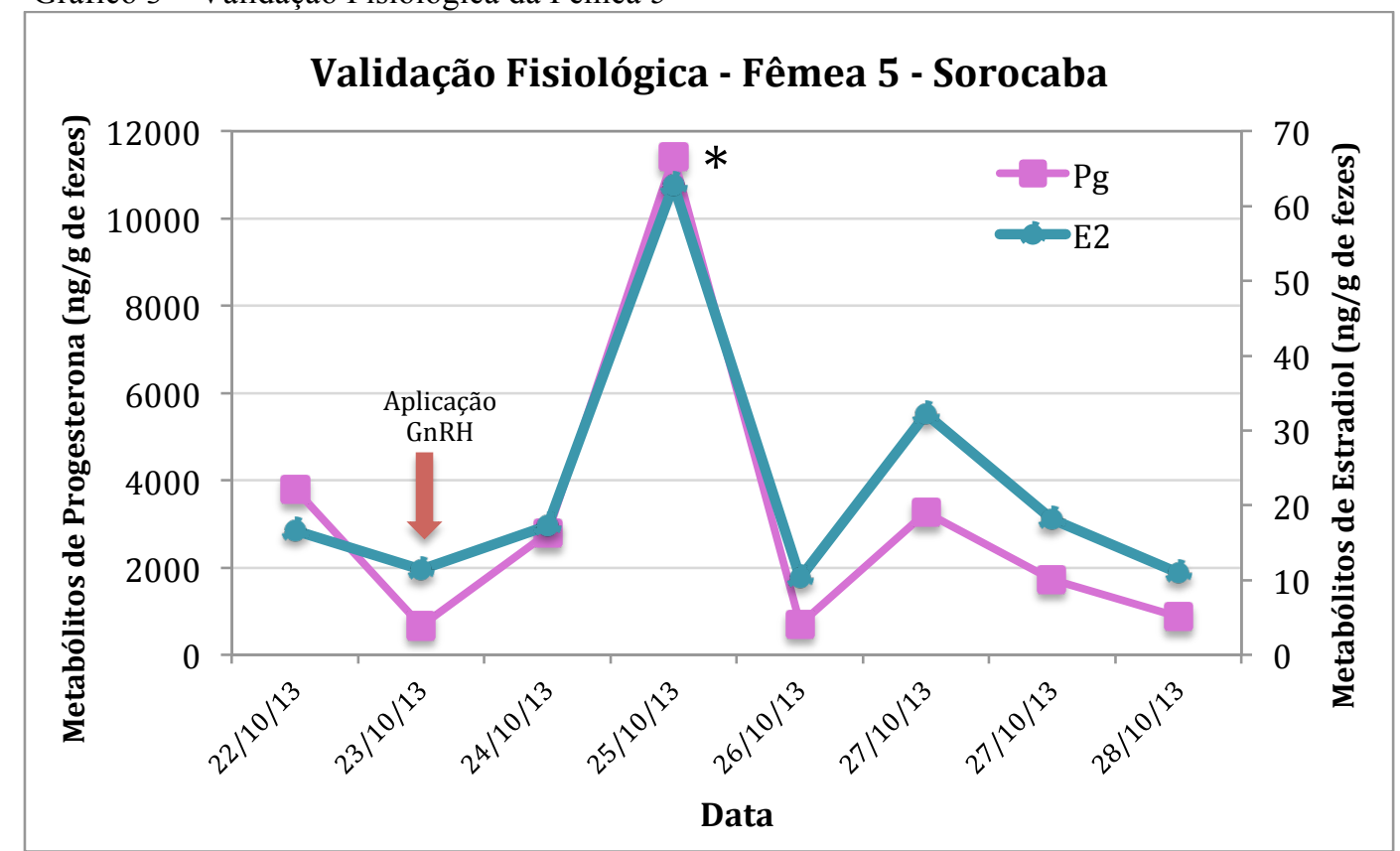

Legenda: A seta vermelha indica a aplicação de GnRH, e o asterisco (*) indicam os picos encontrados.

Gráfico 4 - Validação Fisiológica da Fêmea 6

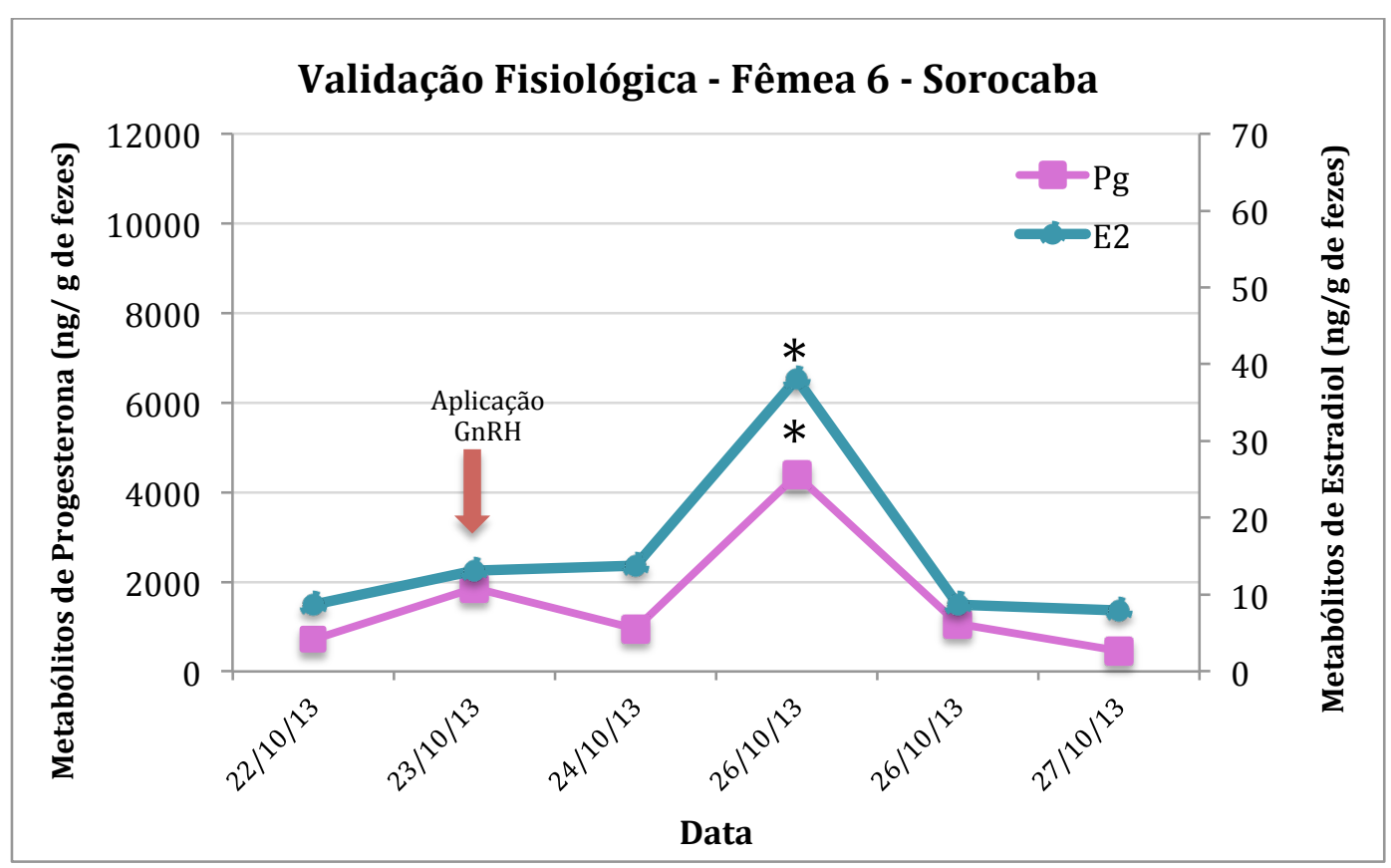

Legenda: A seta vermelha indica a aplicação de GnRH, e o asterisco (*) indicam os picos encontrados. 


\subsection{TESTE DE PARALELISMO}

Os resultados dos testes de paralelismo para cada hormônio estão representados nos gráficos de 5 a 7.

Gráfico 5 - Relação de Paralelismo para ensaio de Progesterona

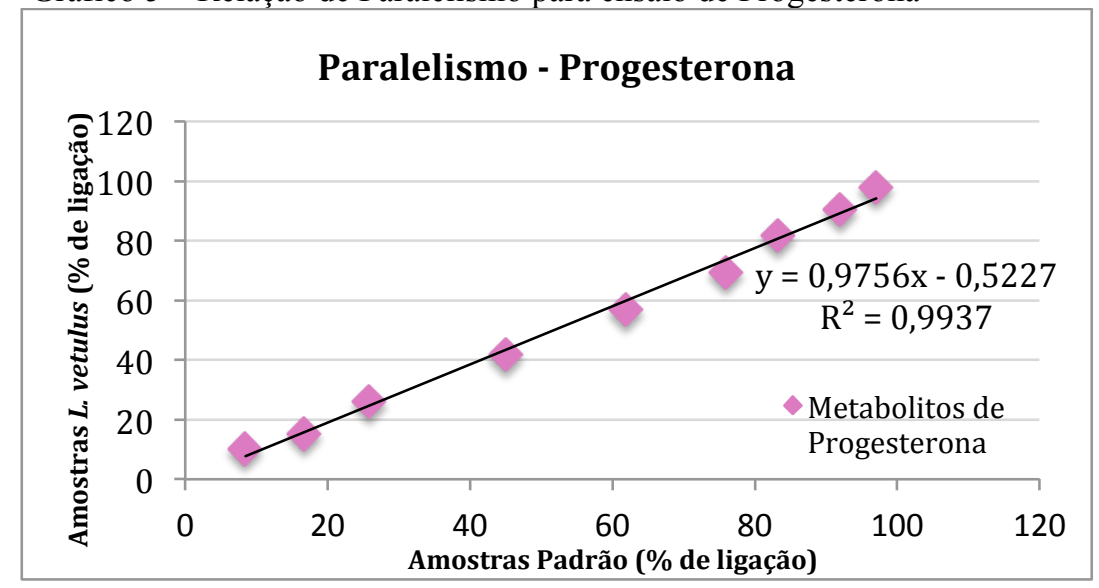

Gráfico 6 - Relação de Paralelismo para ensaio de Conjugado de Estrona

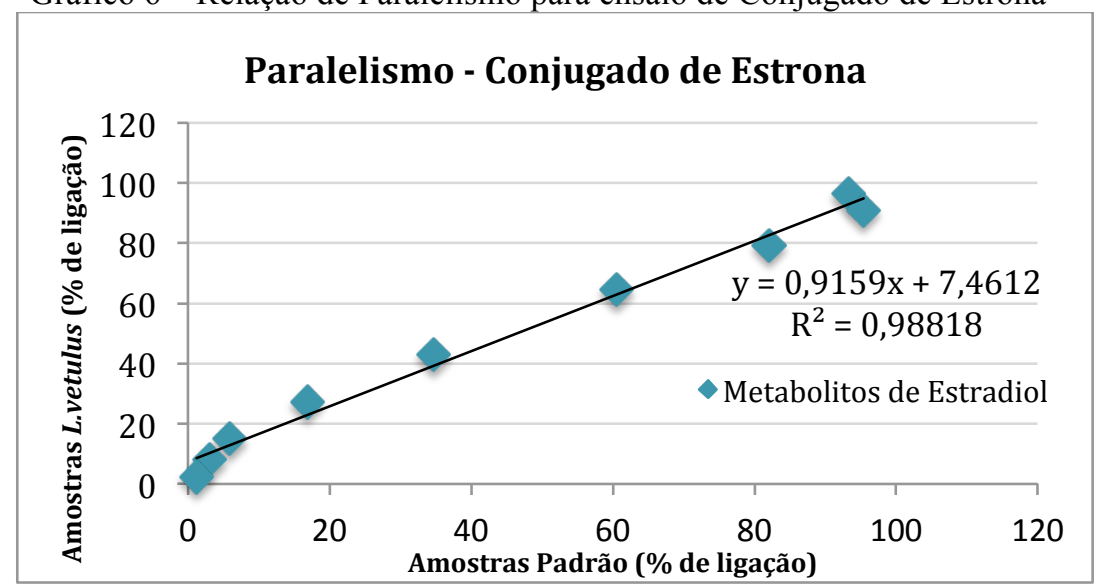

Gráfico 7 - Relação de Paralelismo para ensaio de Corticosterona

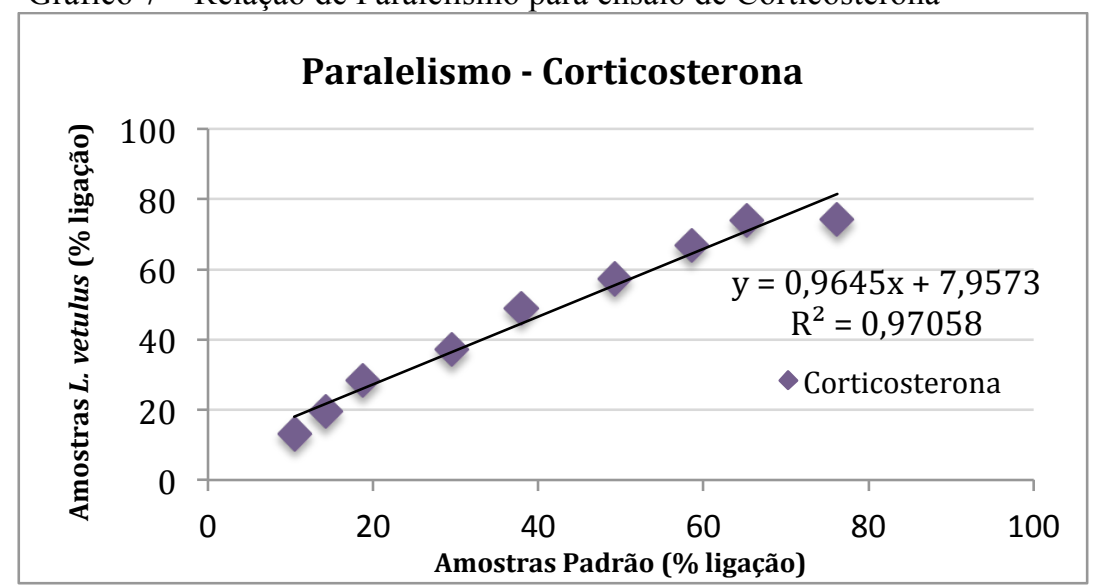


Os testes de paralelismo para os três ensaios realizados (ensaio de progesterona, conjugado de estrona e corticosterona), obtiveram uma boa relação de paralelismo entre as amostras fecais de Lycalopex vetulus com o padrão do laboratório de endocrinologia do SCBI (Instituto Smithsonian de Biologia da Conservação), como demonstram os gráficos 5, 6 e 7.

Os coeficientes de correlação foram de $\mathrm{R}^{2}=0,99$ para progesterona, $\mathrm{R}^{2}=0,98$ para conjugado de estrona e $\mathrm{R}=0,97$ para corticosterona, o que valida os ensaios para as dosagens fecais dos referidos metabólitos para a espécie L. vetulus.

\subsection{TESTE DE ACURÁCIA}

Os resultados dos testes de acurácia para cada hormônio estão representados nos gráficos de 8 a 10 .

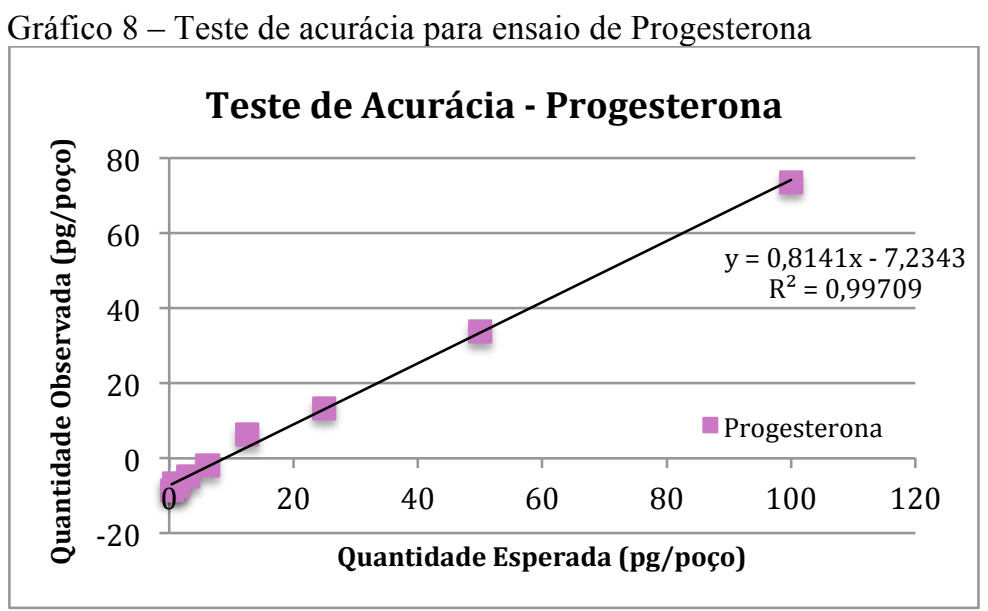

Gráfico 9 - Teste de acurácia para ensaio de Conjugado de Estrona

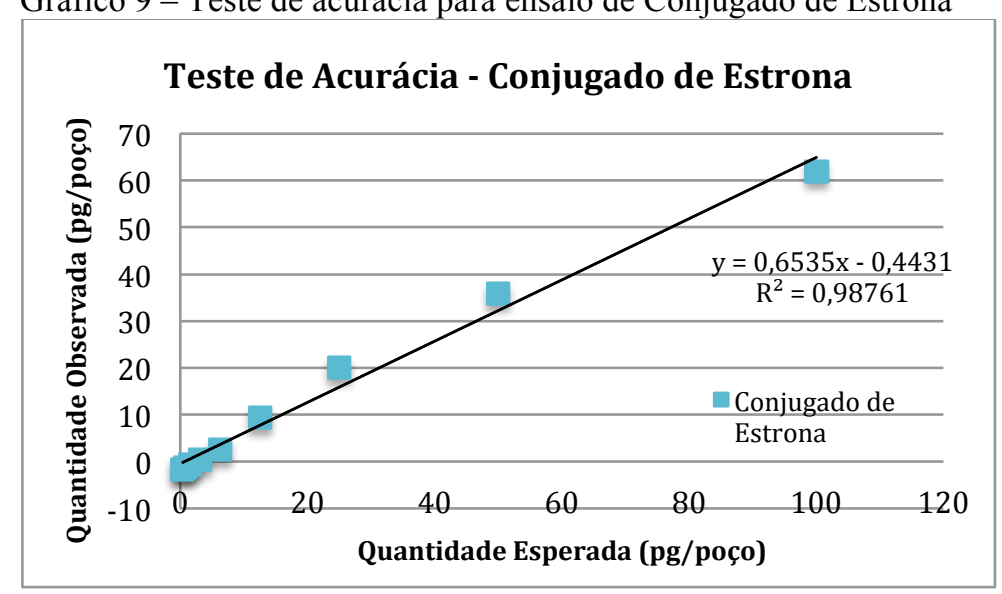




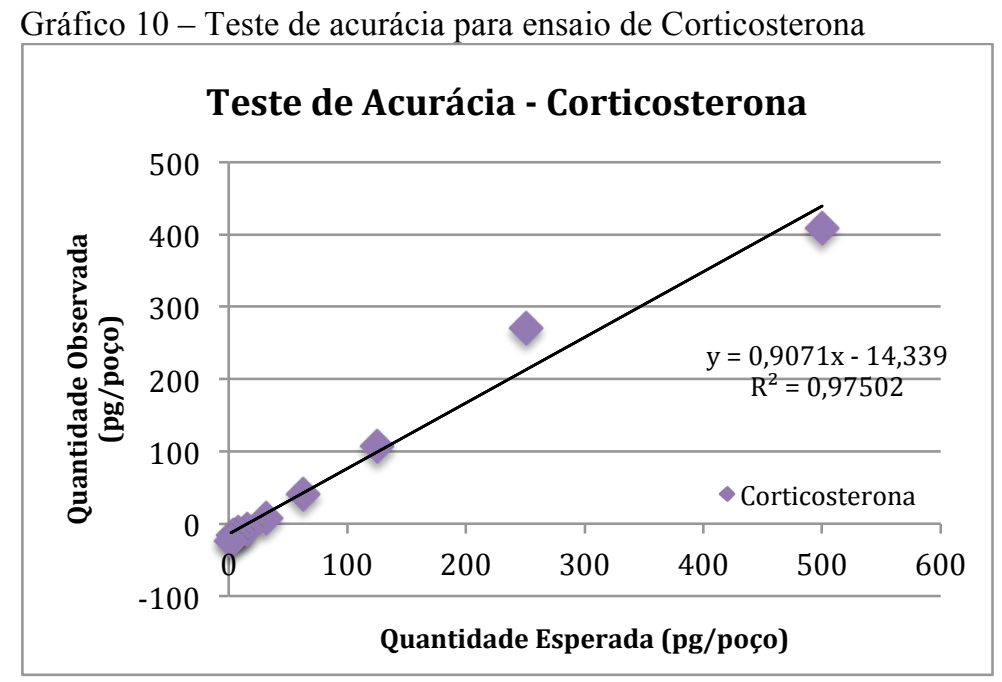

Os testes de acurácia que indicam o grau que a mensuração da concentração corresponde a real concentração da substância também demonstraram um satisfatório coeficiente de relação entre o valor esperado e obtido para os três ensaios, com $R=0,99$ para progesterona, $\mathrm{R}=0,98$ para conjugado de estrona e $\mathrm{R}=0,97$ para corticosterona. A boa resposta desse teste reforça a validação para esses ensaios para as dosagens dos metabólitos fecais de progesterona, estrógeno e glicocorticóides da raposa-do-campo.

\subsection{HPLC}

O teste de HPLC envolve a separação molecular de um pool de amostras com marcadores radioativos pela cromatografia líquida de alta performance e a dosagem das frações por enzimaimunoensaio e pelo contador de radioatividade.

Para os metabólitos fecais de estradiol, os três hormônios marcados com trício utilizados, tri-sulfato de estrona, estrona e estradiol, estão entre os metabólitos de estradiol presentes nas fezes da raposa-do-campo e sensíveis ao ensaio realizado. Além desses metabólitos que puderam ser identificados, o ensaio abrange mais metabólitos de estradiol que ainda precisam ser identificados, como se pode observar no gráfico11.

Com relação aos metabólitos fecais de progesterona, o único hormônio marcado com trício disponível era a progesterona integra, o laboratório não possuía outros metabólitos para a identificação. No gráfico 12 podemos observar as dosagens por enzimaimunoensaio das 
frações, que o ensaio de progesterona está dosando uma grande quantidade de metabólitos diferentes de progesterona, e que dentre esses metabólitos, uma parte é a progesterona integra. Para identificar os principais metabólitos excretados pela raposa-do-campo seria necessário submeter a amostra a um espectrômetro de massa.

Os resultados da dosagem por enzimaimunoensaio das frações geradas no HPLC e a contagem radioativa das mesmas frações para metabólitos de estradiol e progesterona estão representados nos gráficos 11 e 12 .

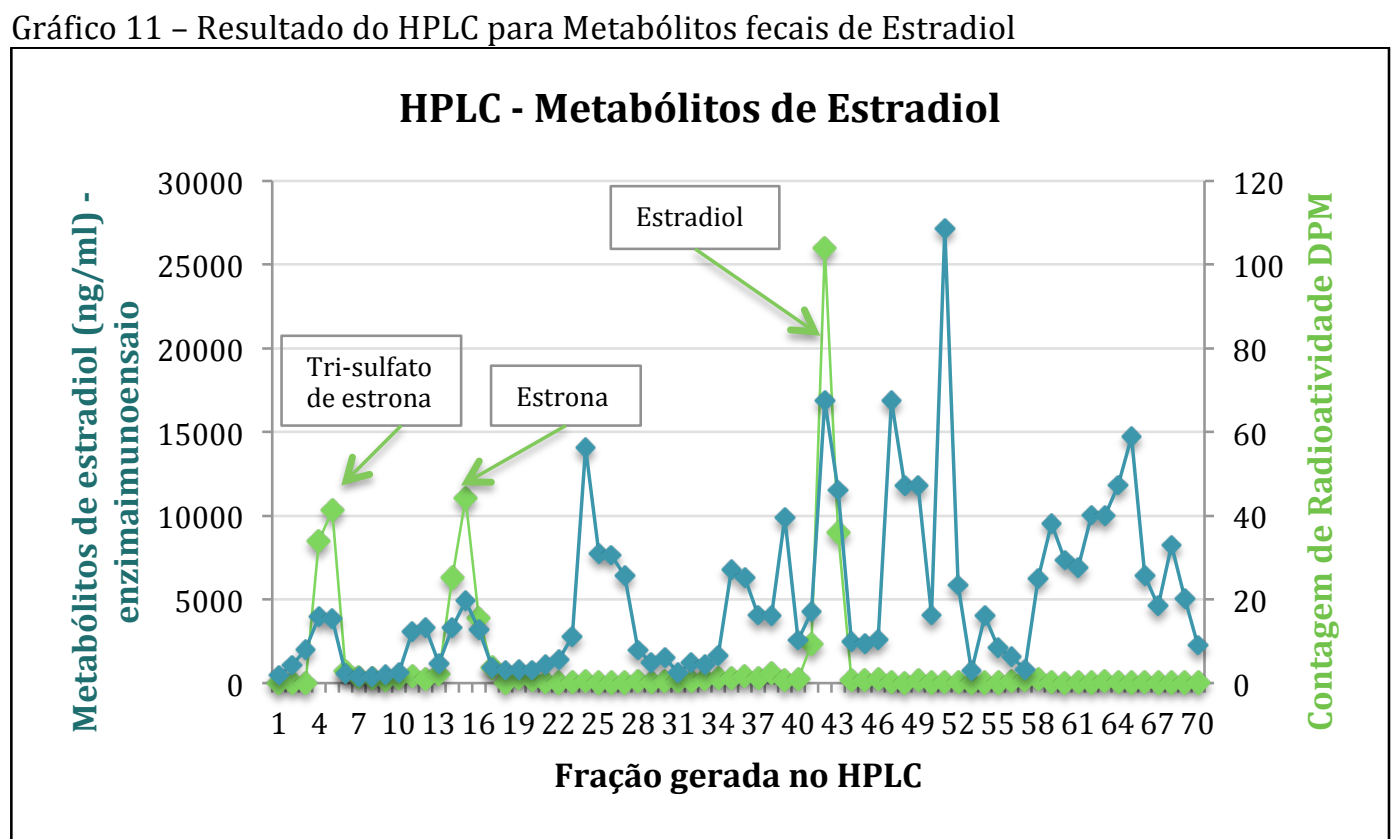

Gráfico 12 - Resultado do HPLC para Metabólitos fecais de Progesterona

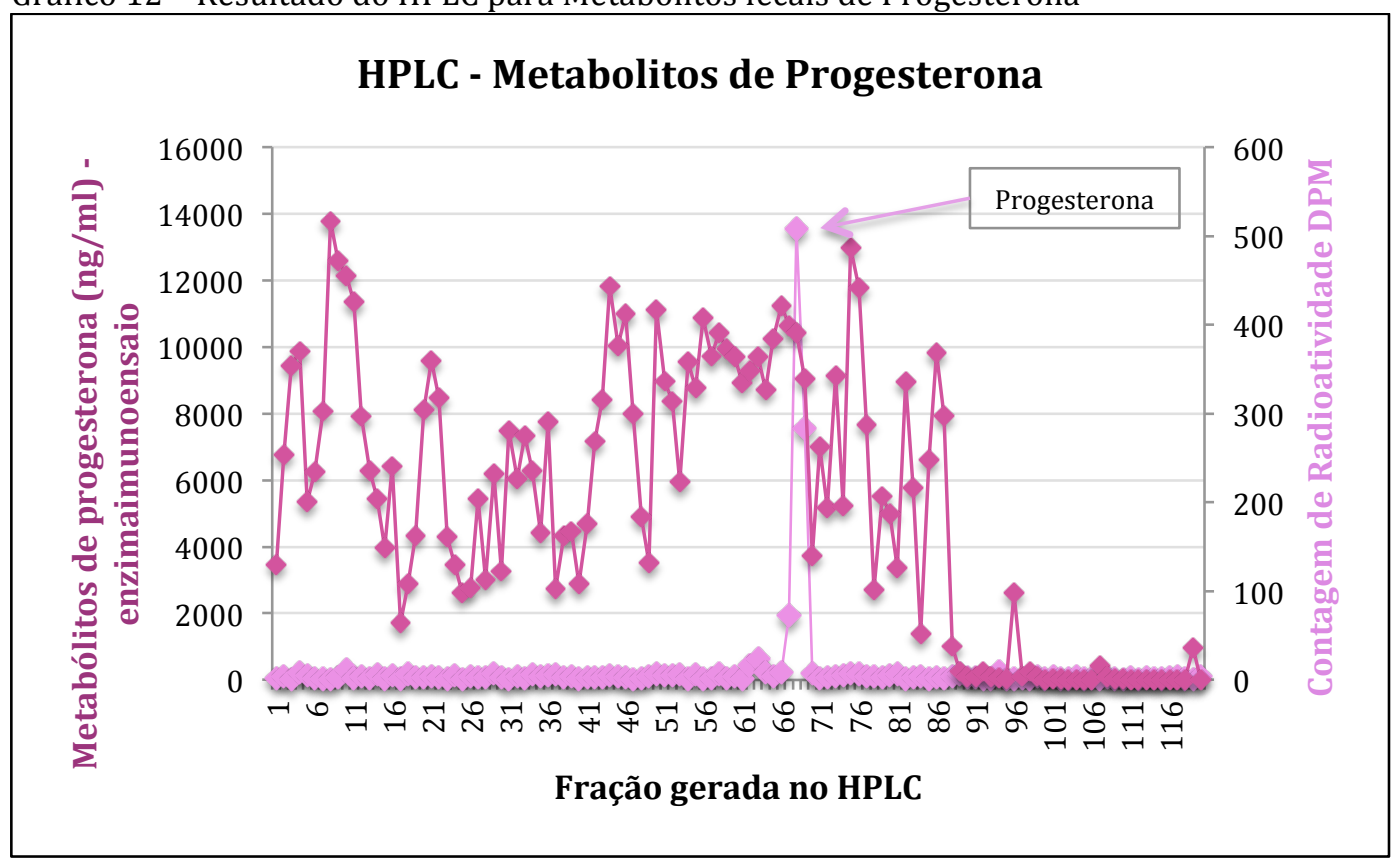




\subsection{DOSAGEM DOS METABÓLITOS FECAIS DE PROGESTERONA}

As dosagens dos metabólitos fecais de progesterona para cada fêmea estão representados nos gráficos de 13 a 20 juntamente com a linha basal calculada para cada indivíduo e a linha que separa os picos, onde os valores que estão acima da linha verde são considerados picos.

Gráfico 13 - Dosagem dos metabólitos fecais de Progesterona para a Fêmea 1

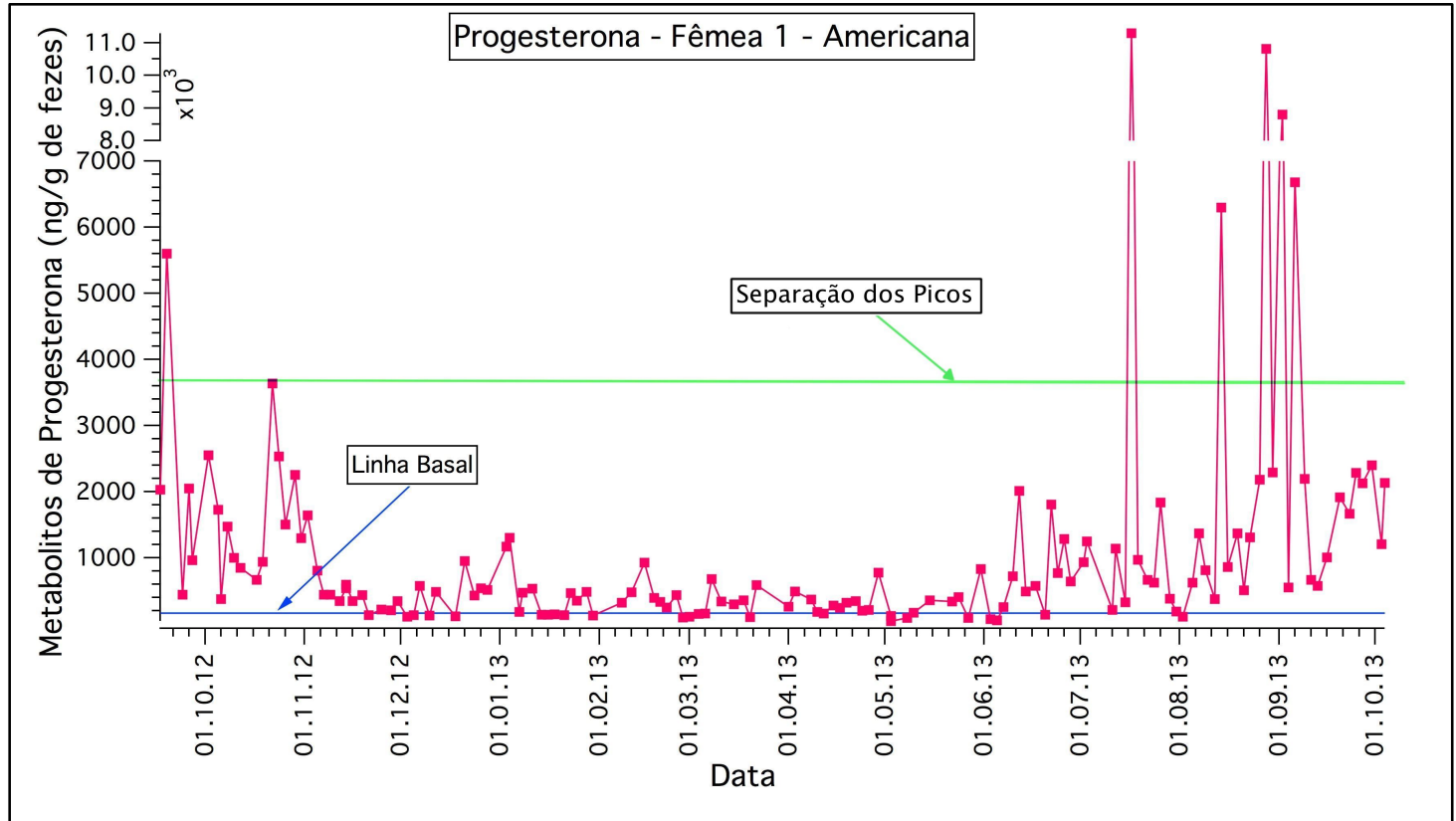

Gráfico 14 - Dosagem dos metabólitos fecais de Progesterona para a Fêmea 2

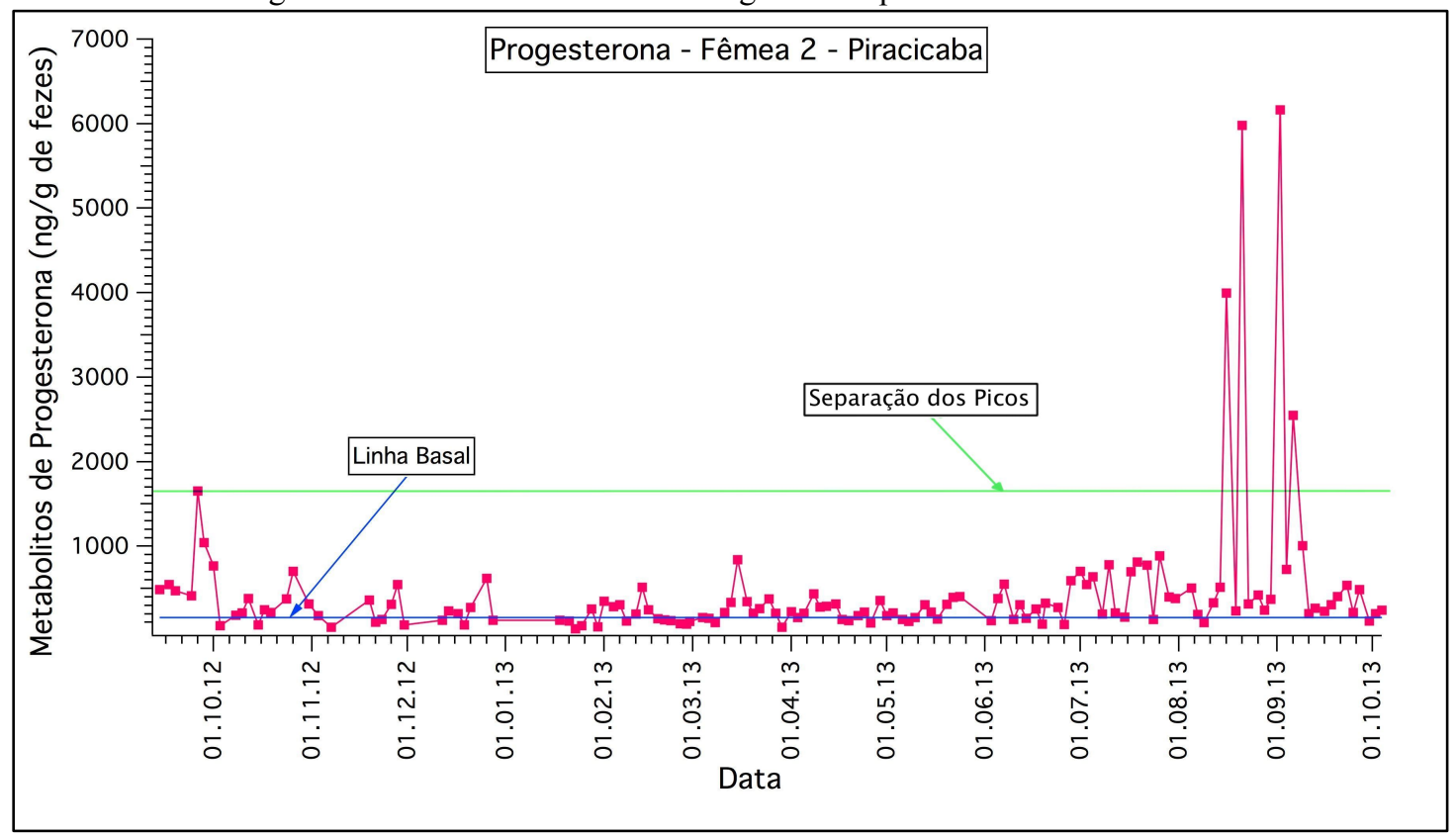


Gráfico 15 - Dosagem dos metabólitos fecais de Progesterona para a Fêmea 3

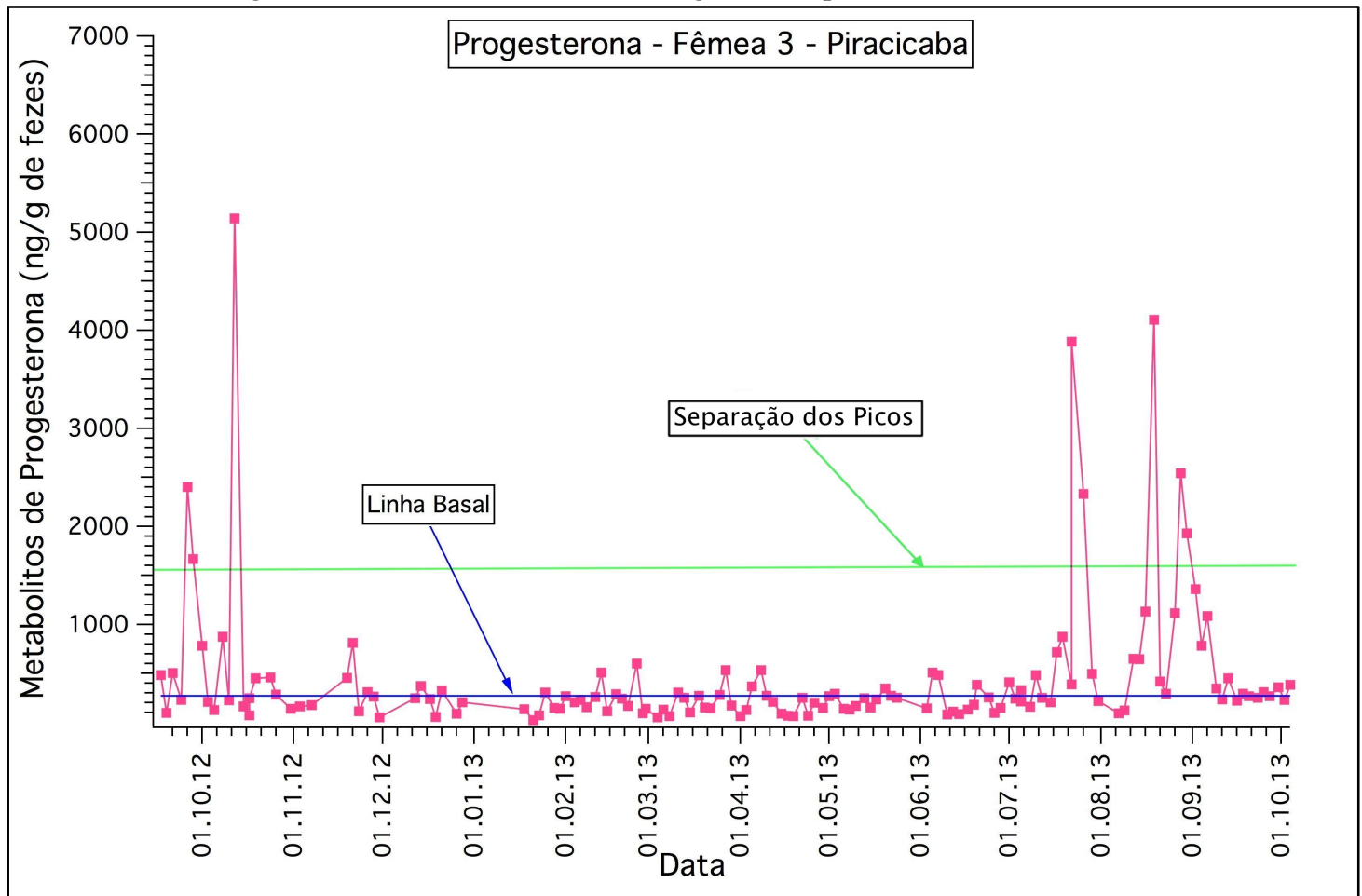

Gráfico 16 - Dosagem dos metabólitos fecais de Progesterona para a Fêmea 4

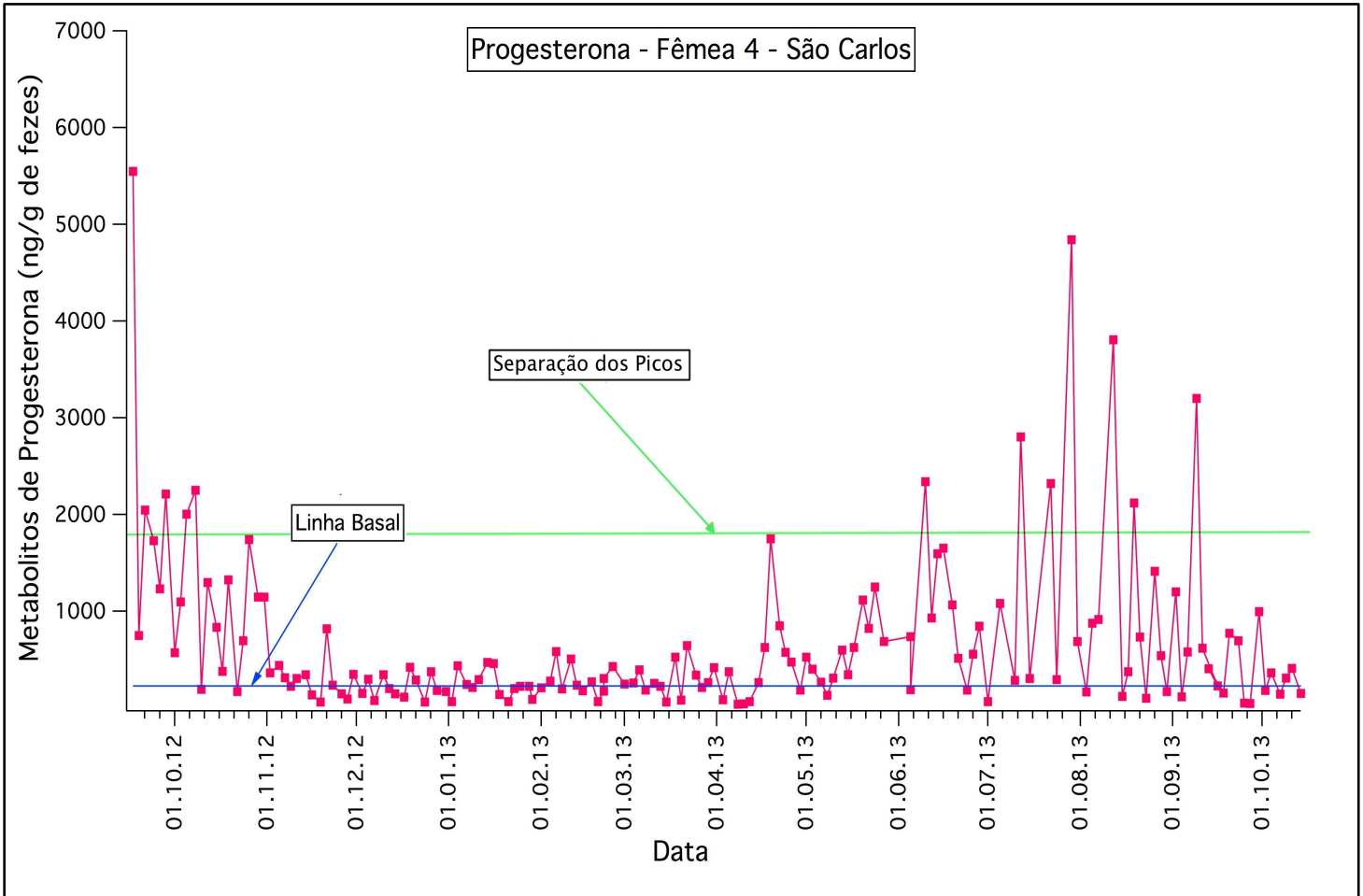


Gráfico 17 - Dosagem dos metabólitos fecais de Progesterona para a Fêmea 5

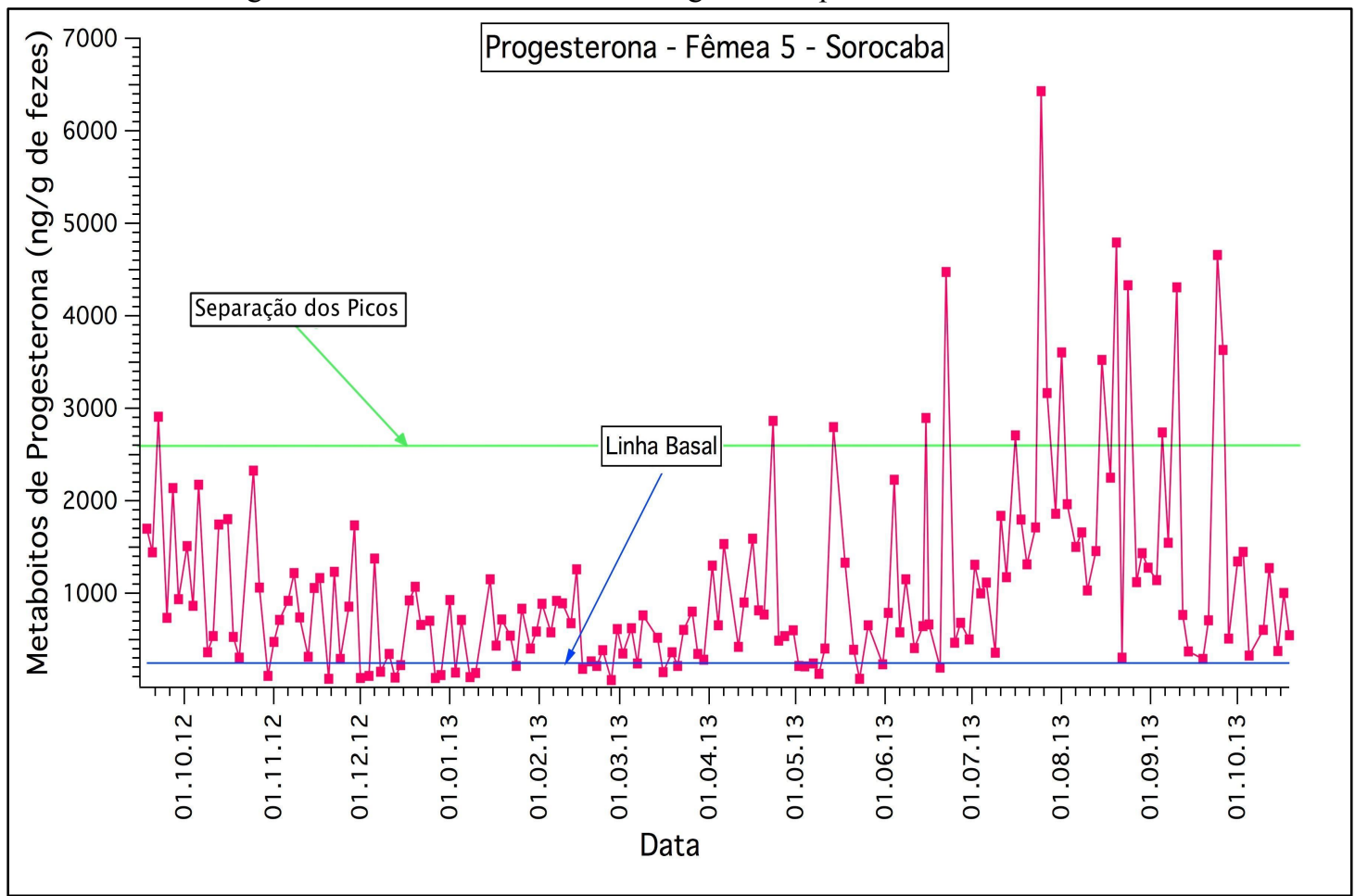

Gráfico 18 - Dosagem dos metabólitos fecais de Progesterona para a Fêmea 6

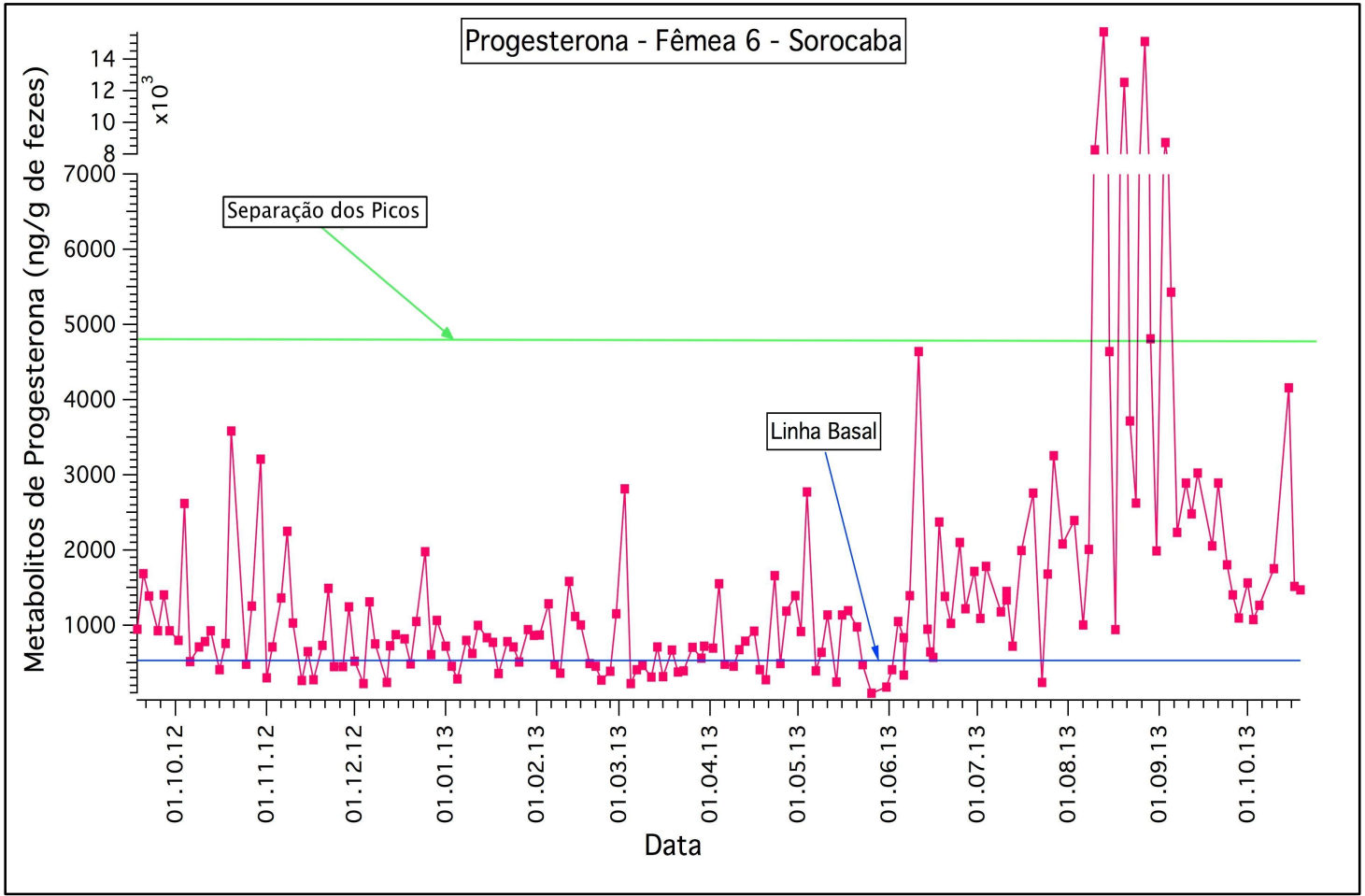


Gráfico 19 - Dosagem dos metabólitos fecais de Progesterona para a Fêmea 7

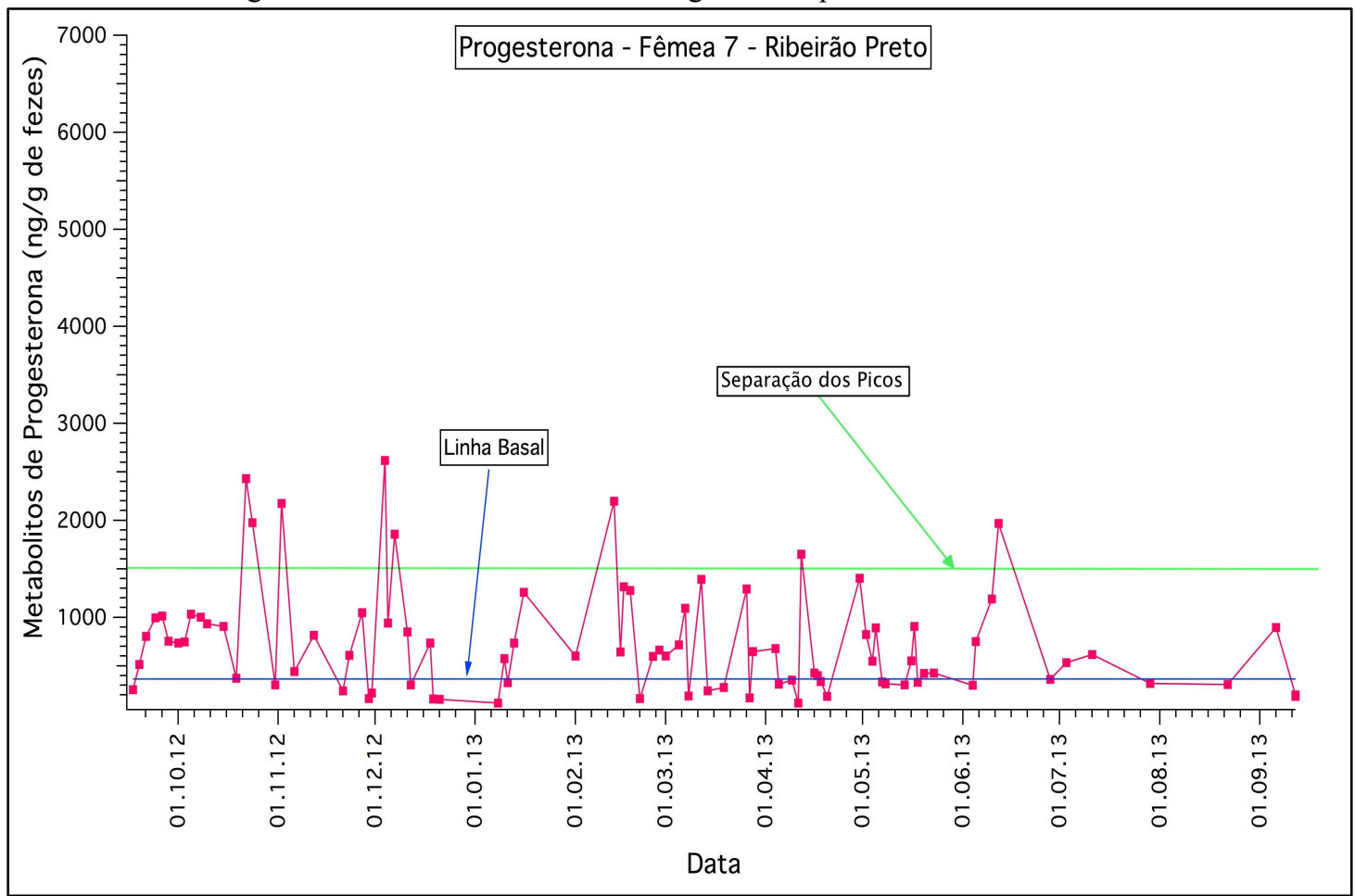

Gráfico 20 - Dosagem dos metabólitos fecais de Progesterona para a Fêmea 8

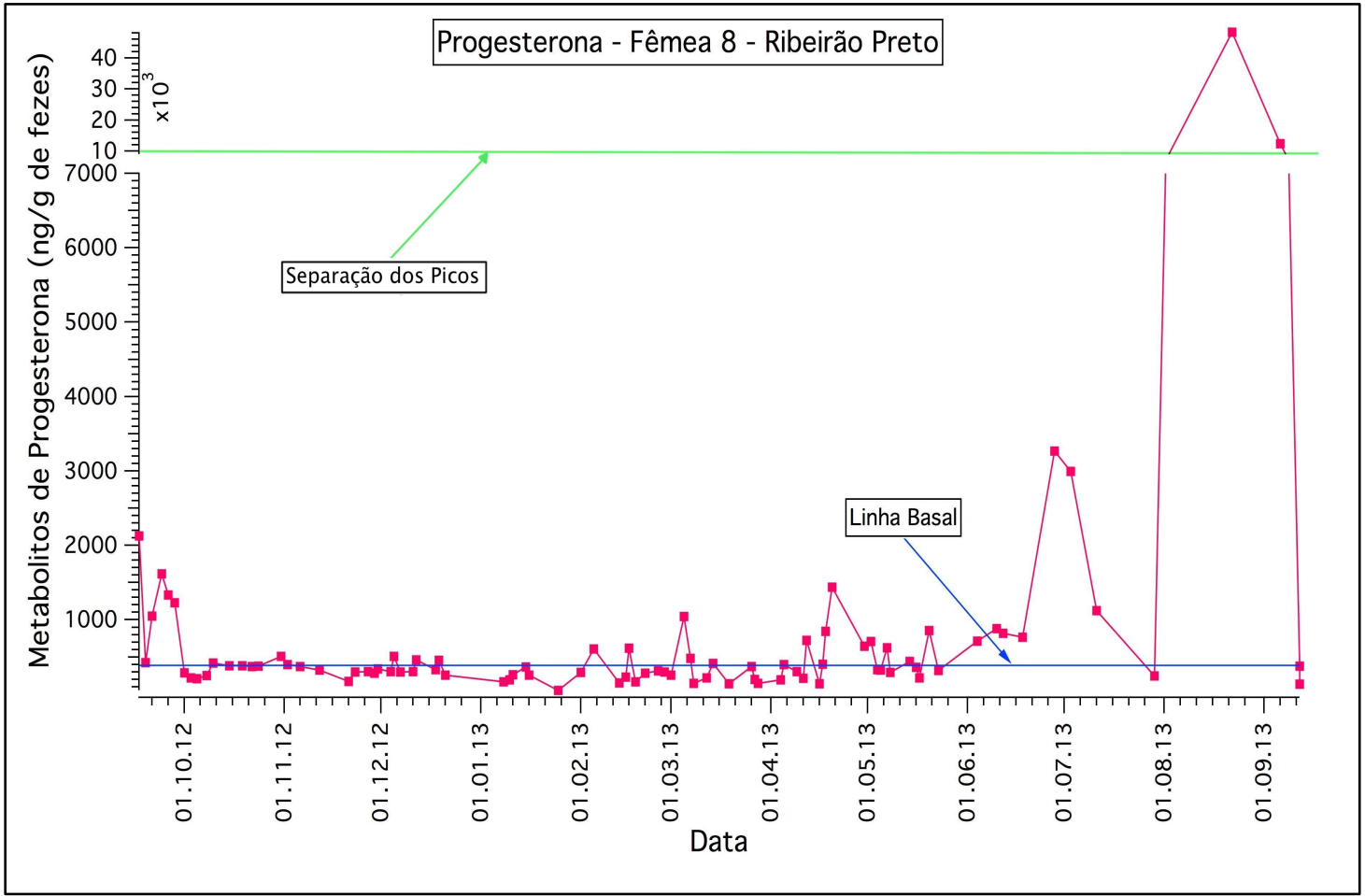




\subsection{DOSAGEM DOS METABÓLITOS FECAIS DE ESTRADIOL}

As dosagens dos metabólitos fecais de estradiol para cada fêmea estão representados nos gráficos de 21 a 28 juntamente com a linha basal calculada para cada indivíduo e a linha que separa os picos, onde os valores que estão acima da linha verde são considerados picos.

Gráfico 21 - Dosagem dos metabólitos fecais de Estradiol para a Fêmea 1

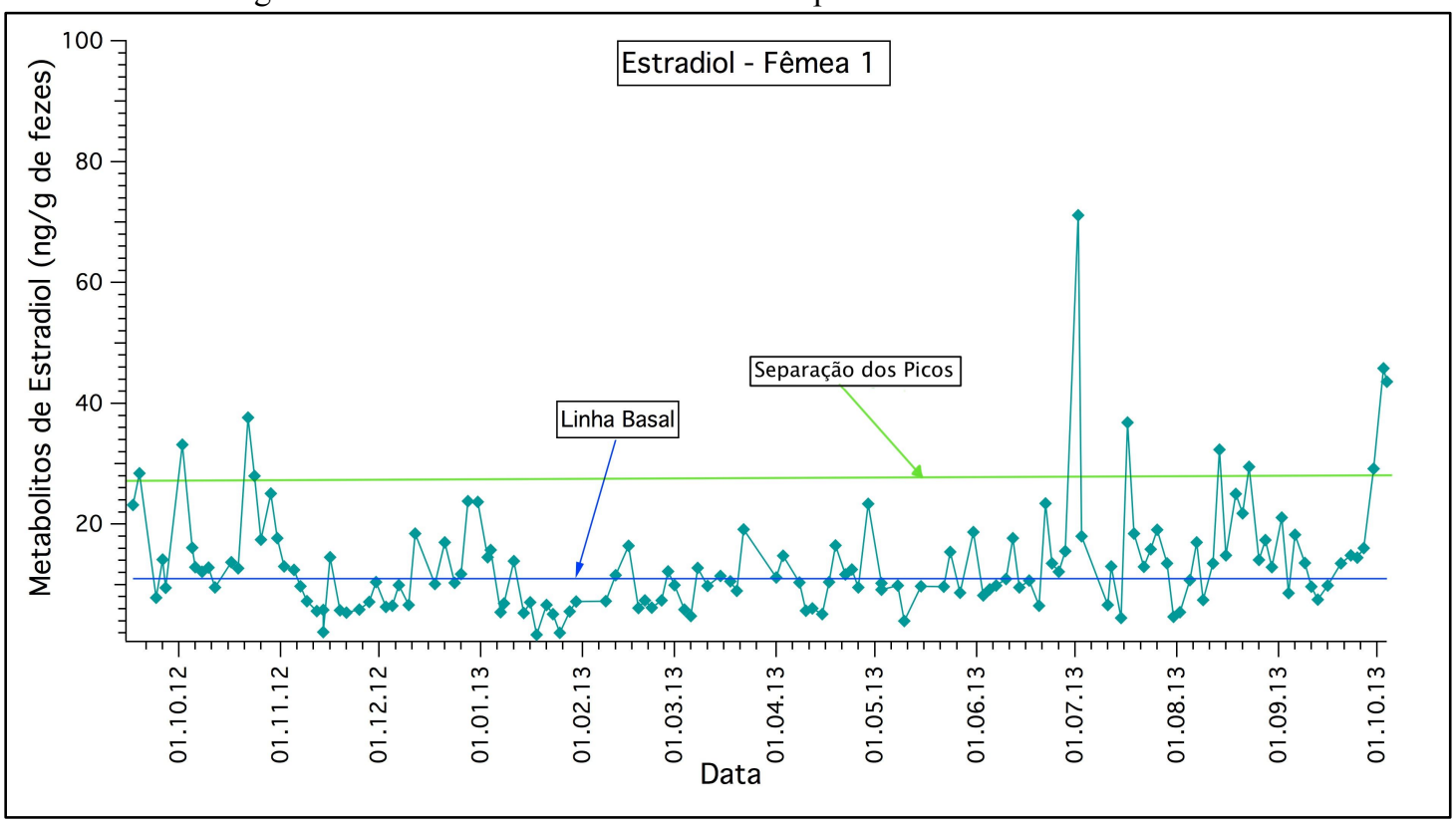

Gráfico 22 - Dosagem dos metabólitos fecais de Estradiol para a Fêmea 2

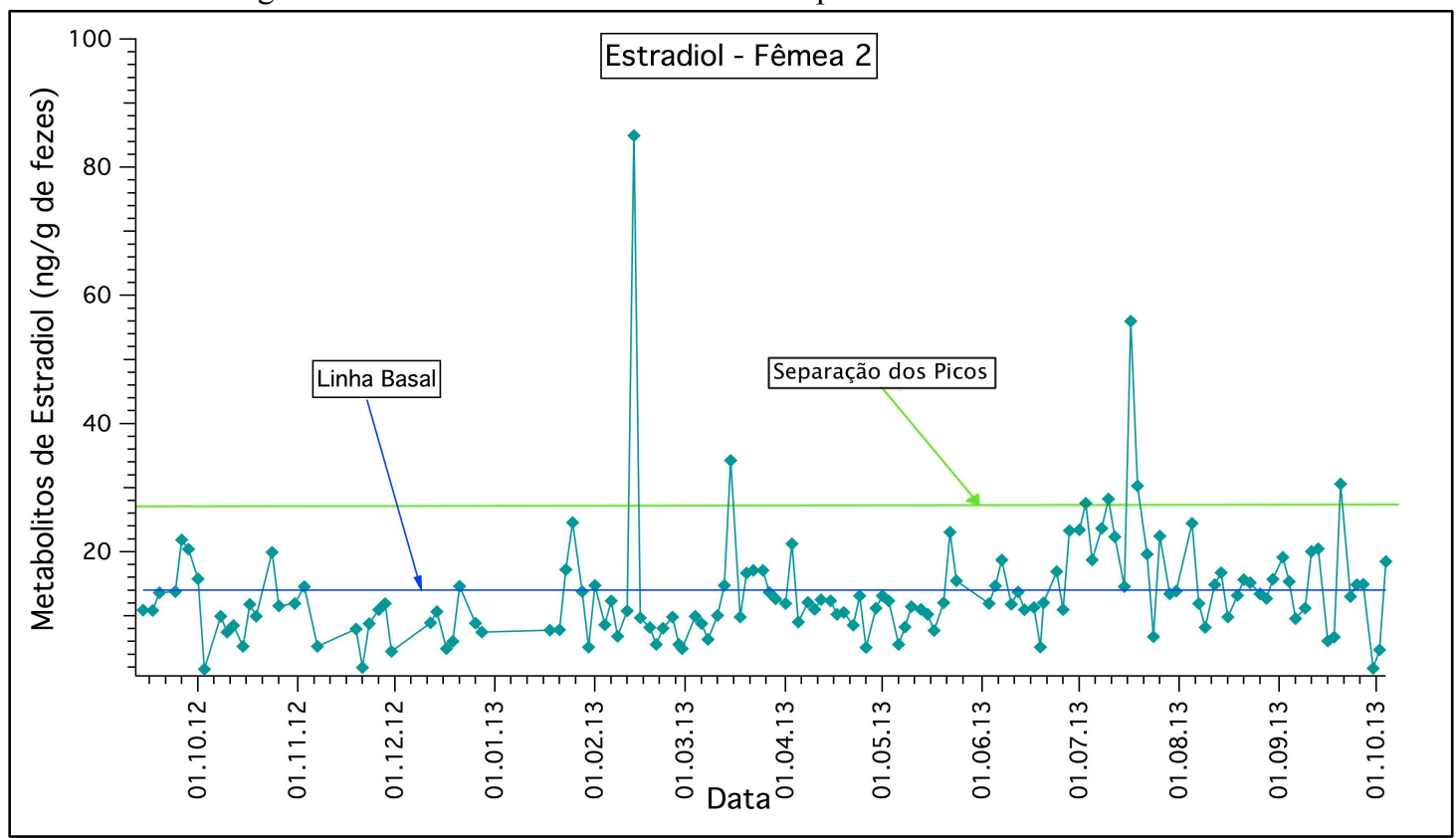


Gráfico 23 - Dosagem dos metabólitos fecais de Estradiol para a Fêmea 3

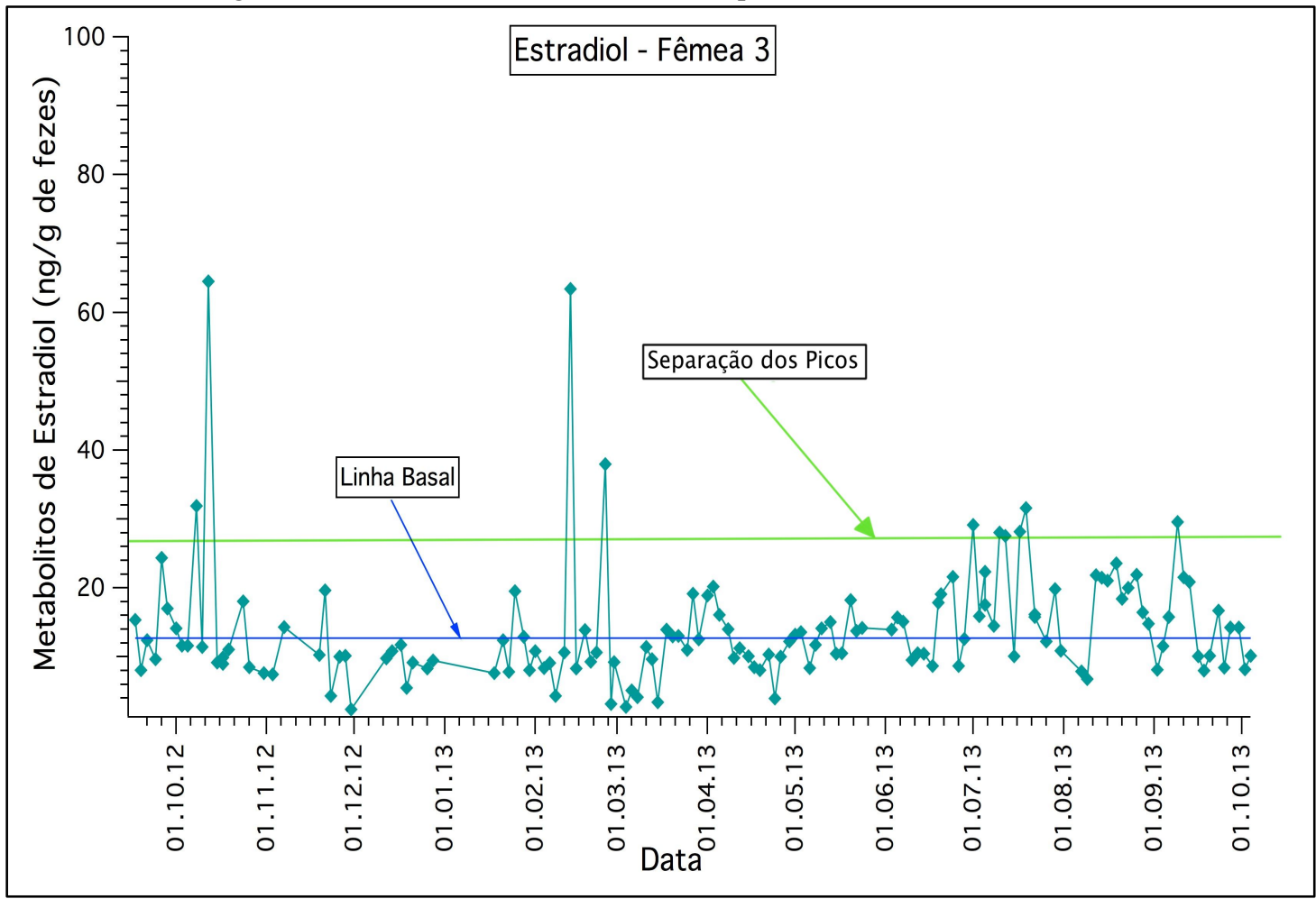

Gráfico 24 - Dosagem dos metabólitos fecais de Estradiol para a Fêmea 4

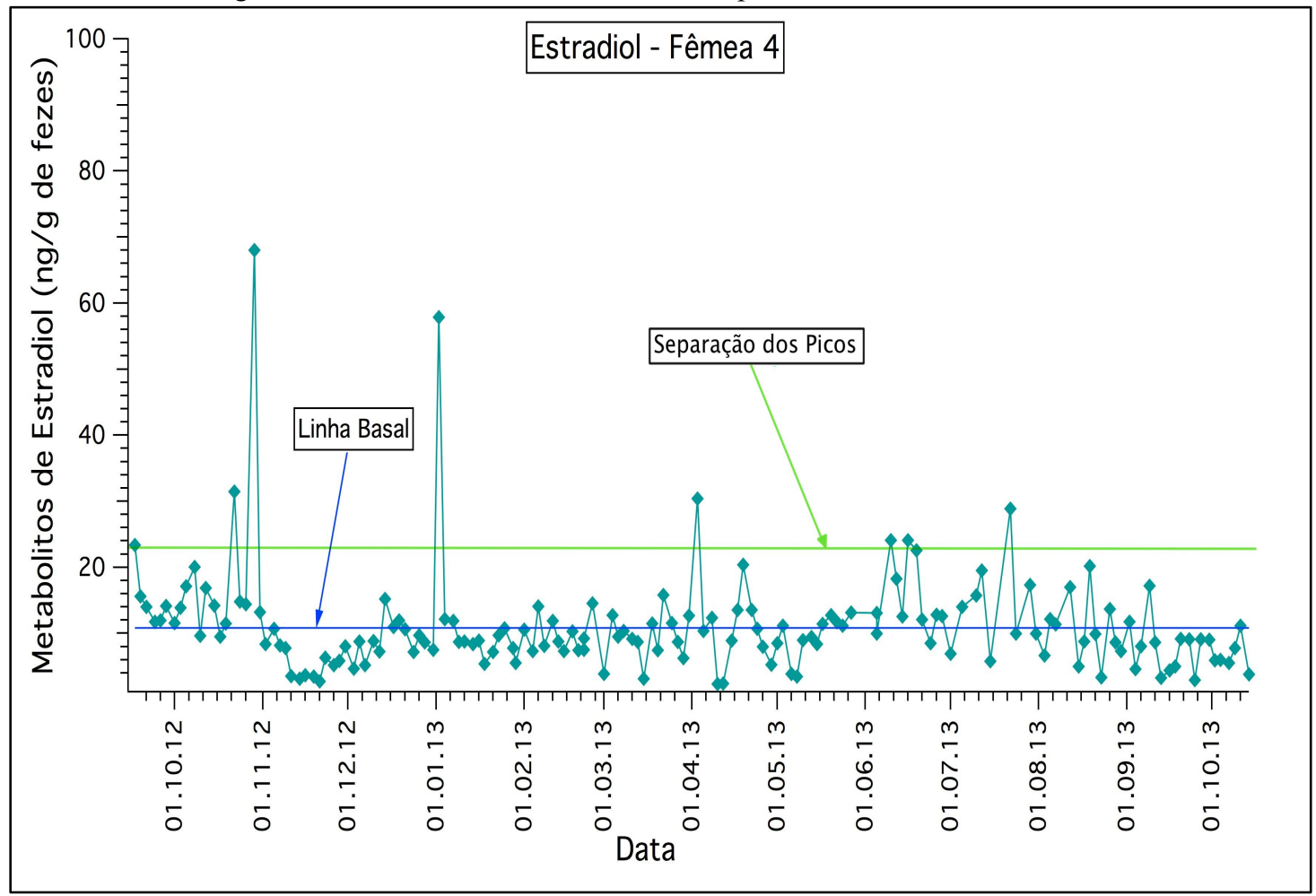


Gráfico 25 - Dosagem dos metabólitos fecais de Estradiol para a Fêmea 5

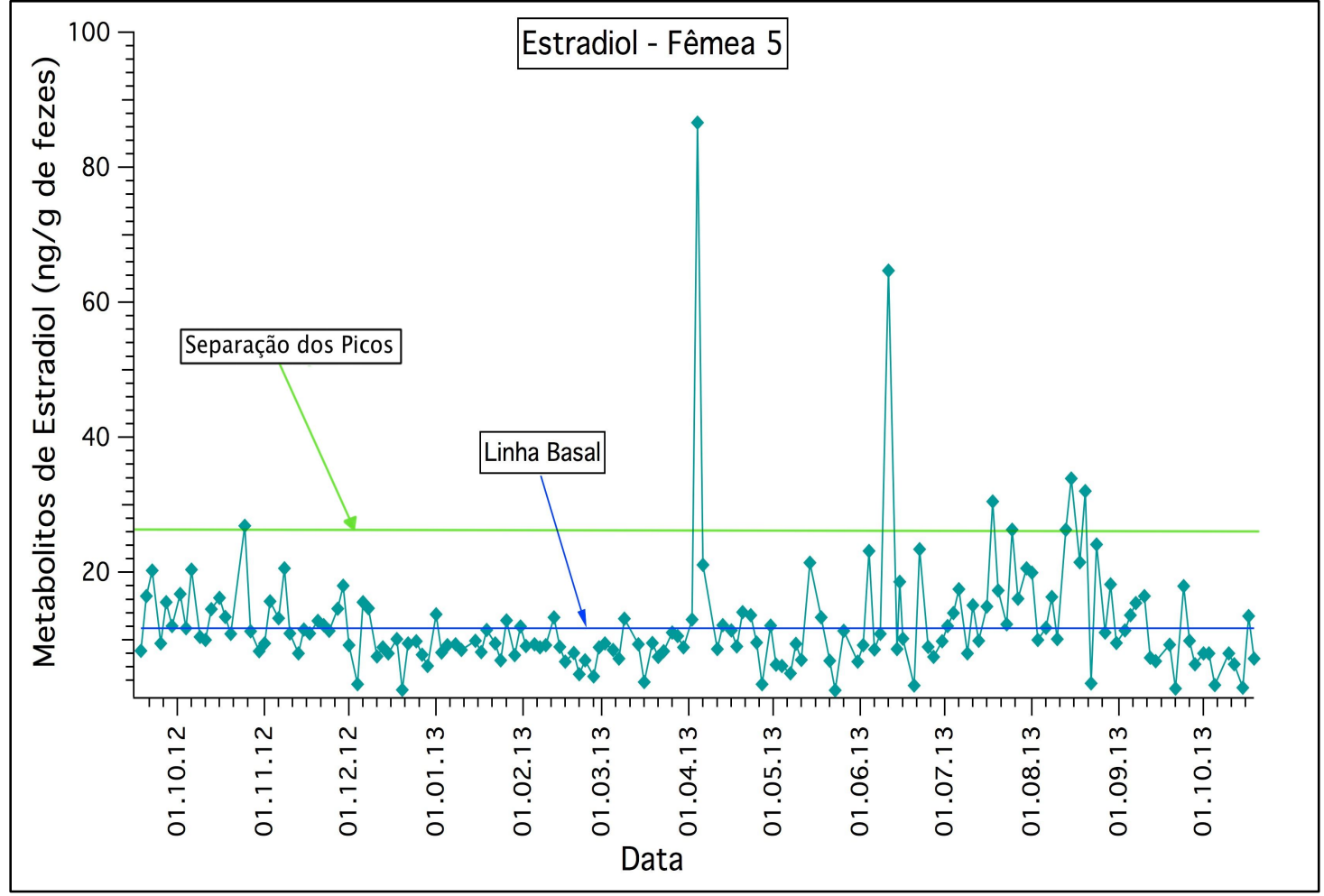

Gráfico 26 - Dosagem dos metabólitos fecais de Estradiol para a Fêmea 6

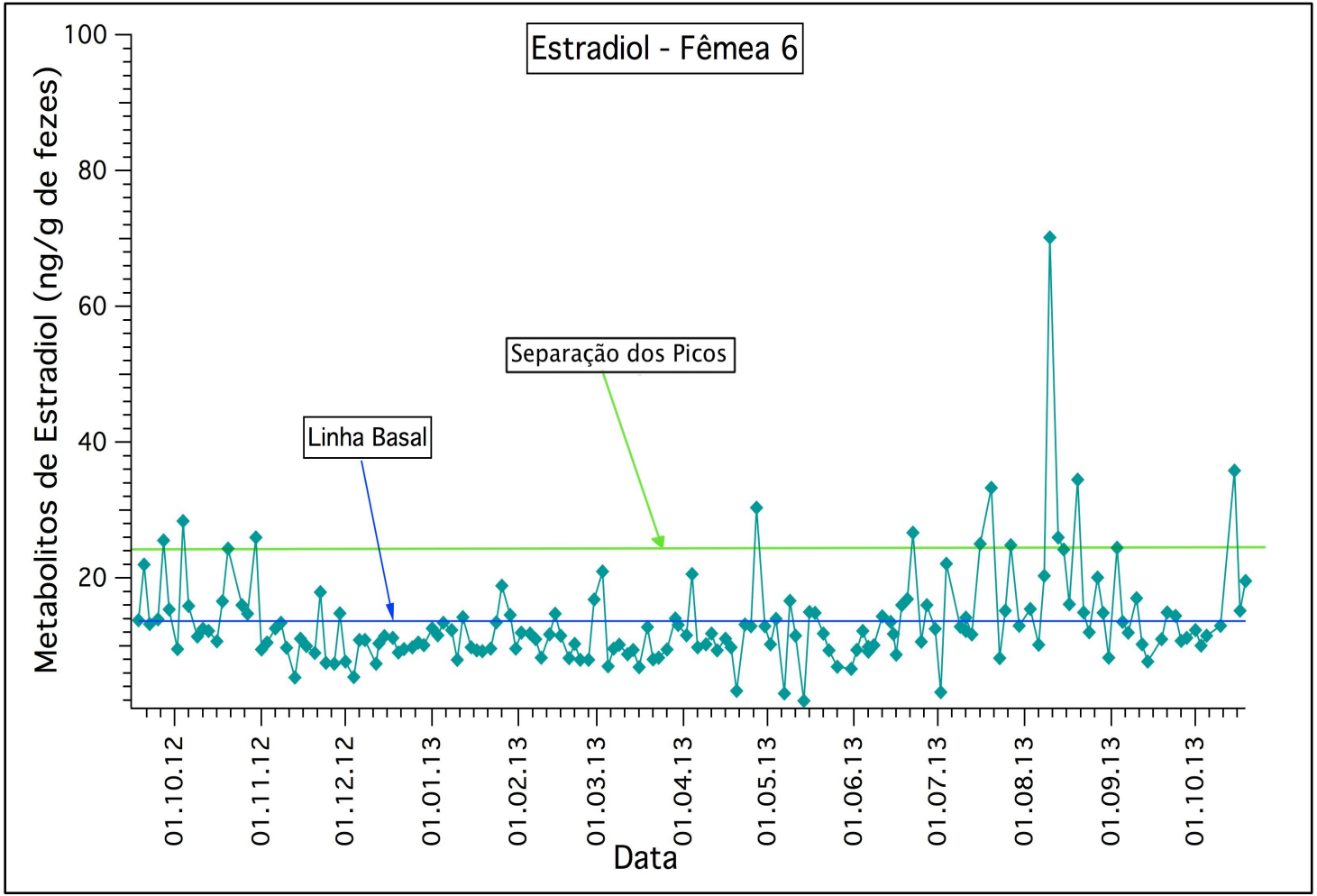


Gráfico 27 - Dosagem dos metabólitos fecais de Estradiol para a Fêmea 7

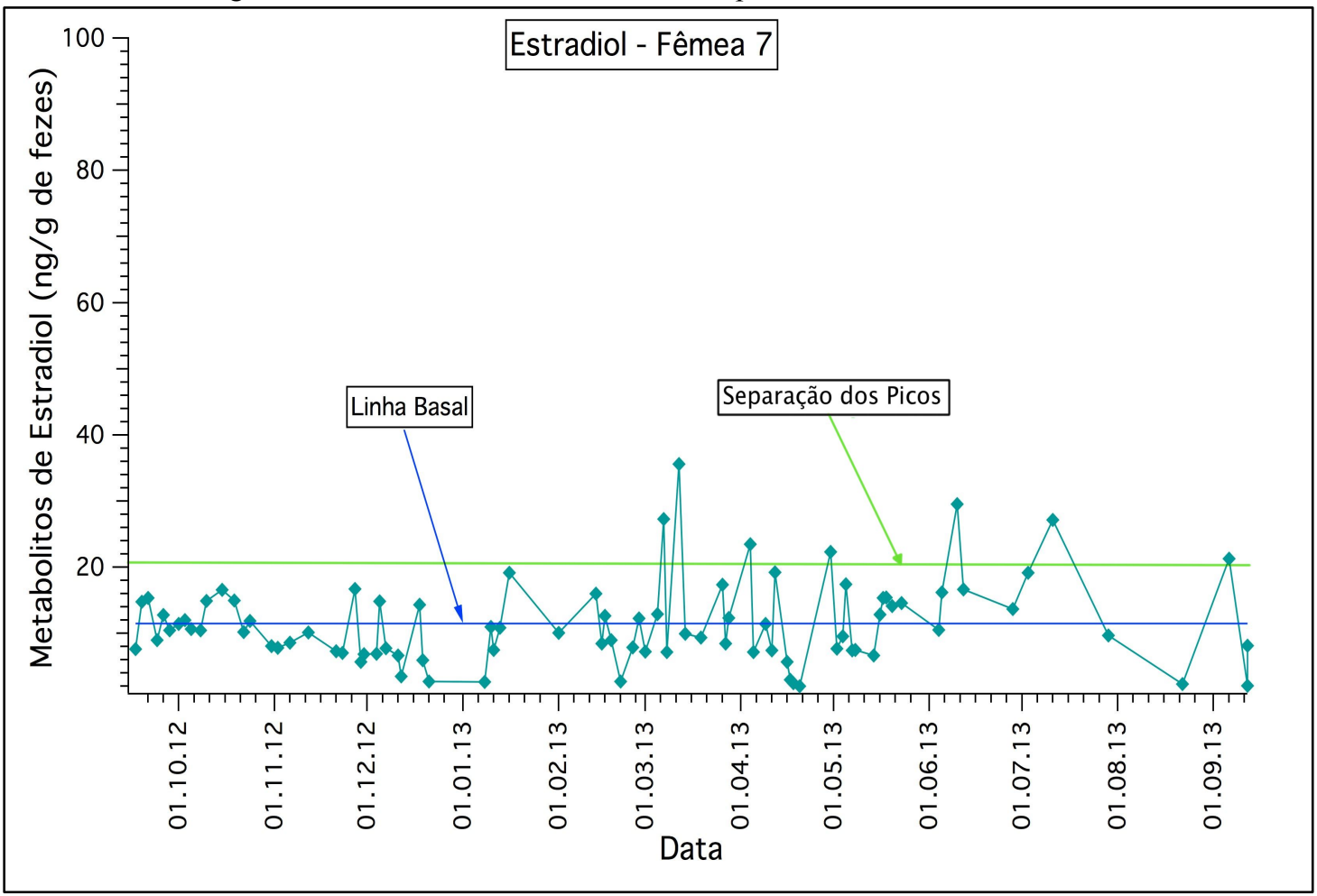

Gráfico 28 - Dosagem dos metabólitos fecais de Estradiol para a Fêmea 8

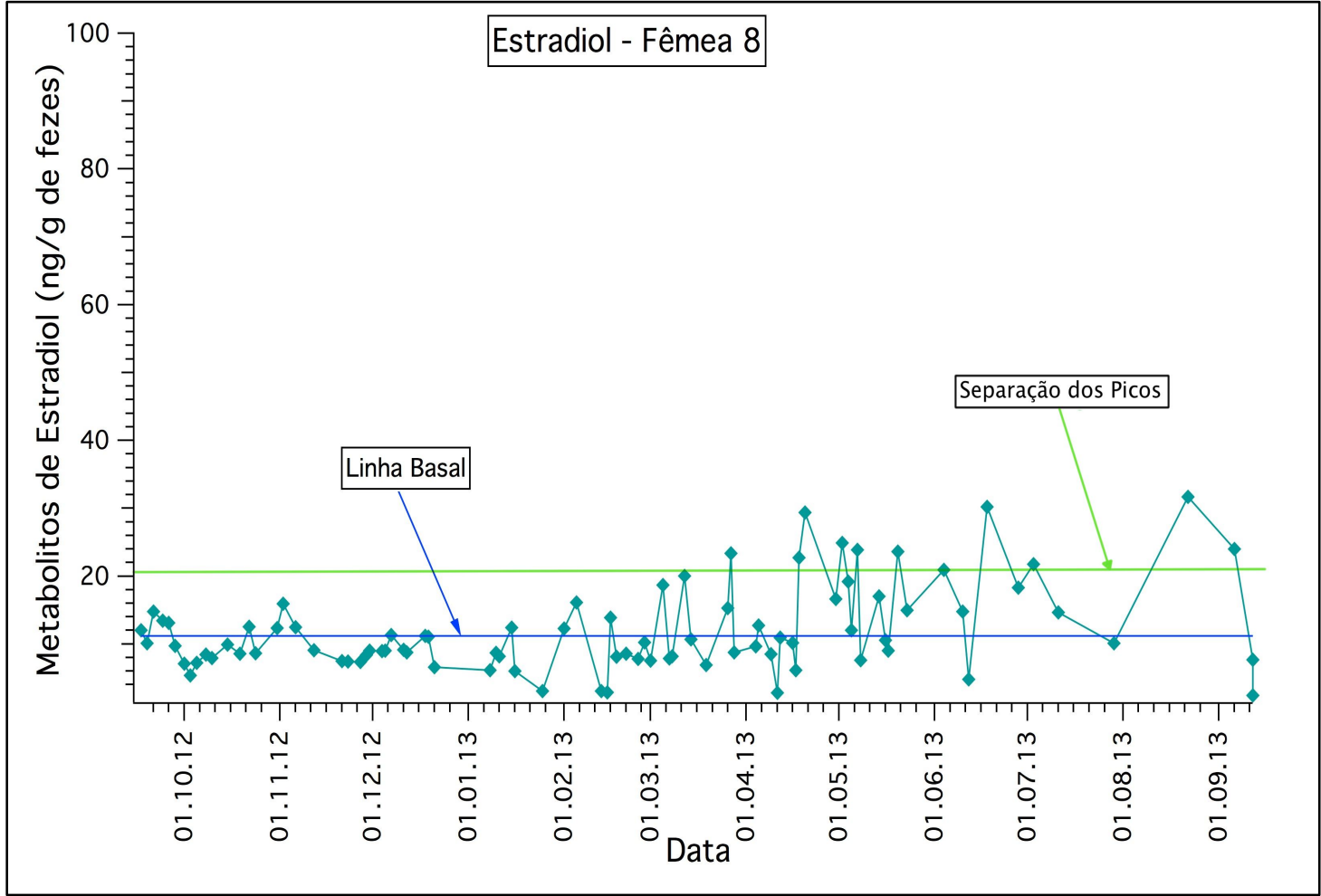




\subsection{DOSAGEM DOS METABÓLITOS FECAIS DE PROGESTERONA, ESTRADIOL E GLICOCORTICÓIDES}

Nos gráficos 29, 31, 33, 35, 37, 39, 41 e 43 estão representadas as concentrações dos metabólitos fecais de progesterona e estradiol juntos para cada fêmea. Os gráficos 30, 32, 34, 36, 38, 40, 42 e 44 correspondem as dosagens dos metabólitos de glicocorticóides de cada indivíduo no mesmo período.

Gráfico 29 - Dosagem dos metabólitos fecais de Progesterona e Estradiol para a Fêmea 1

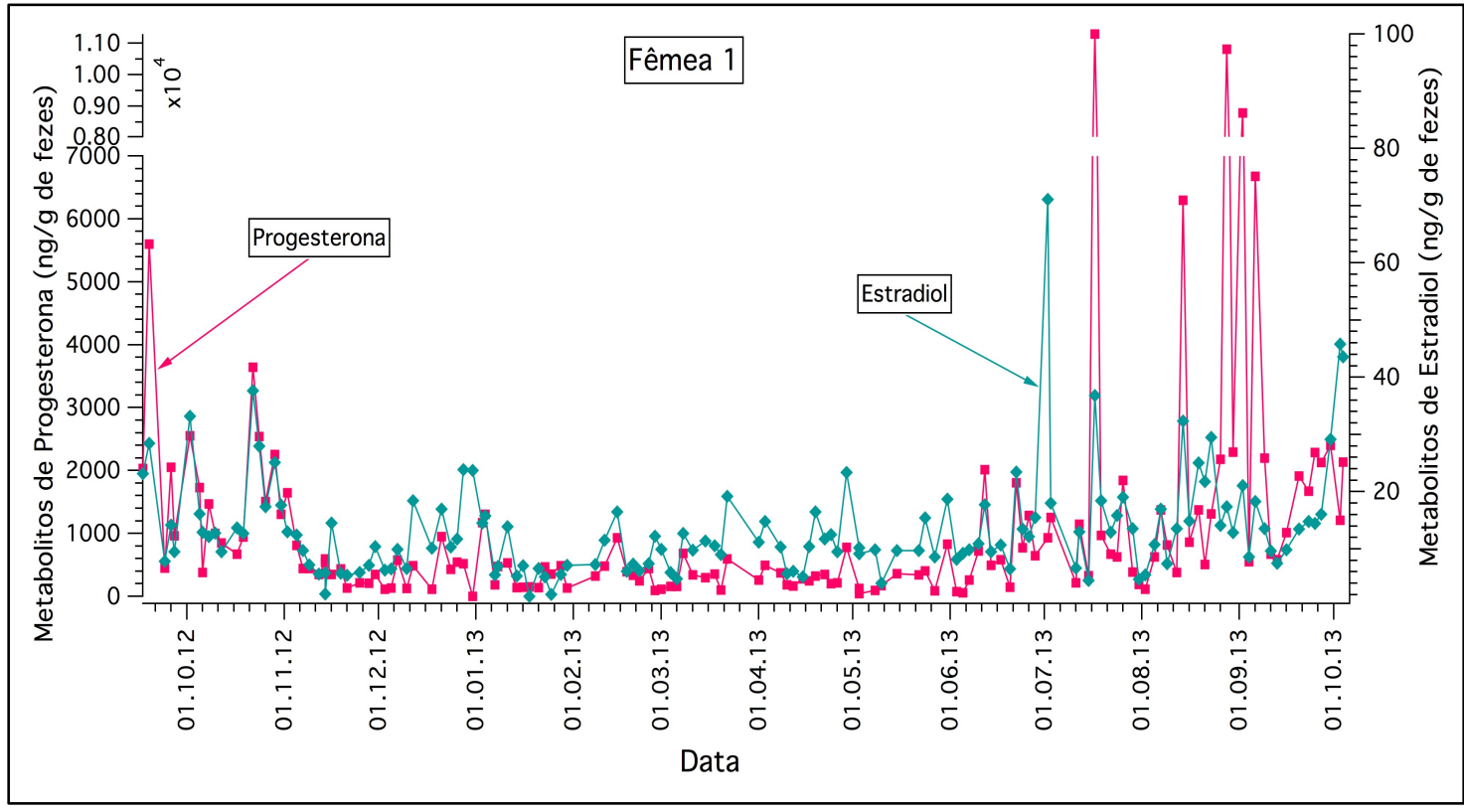

Gráfico 30 - Dosagem dos metabólitos fecais de Glicocorticóides para a Fêmea 1

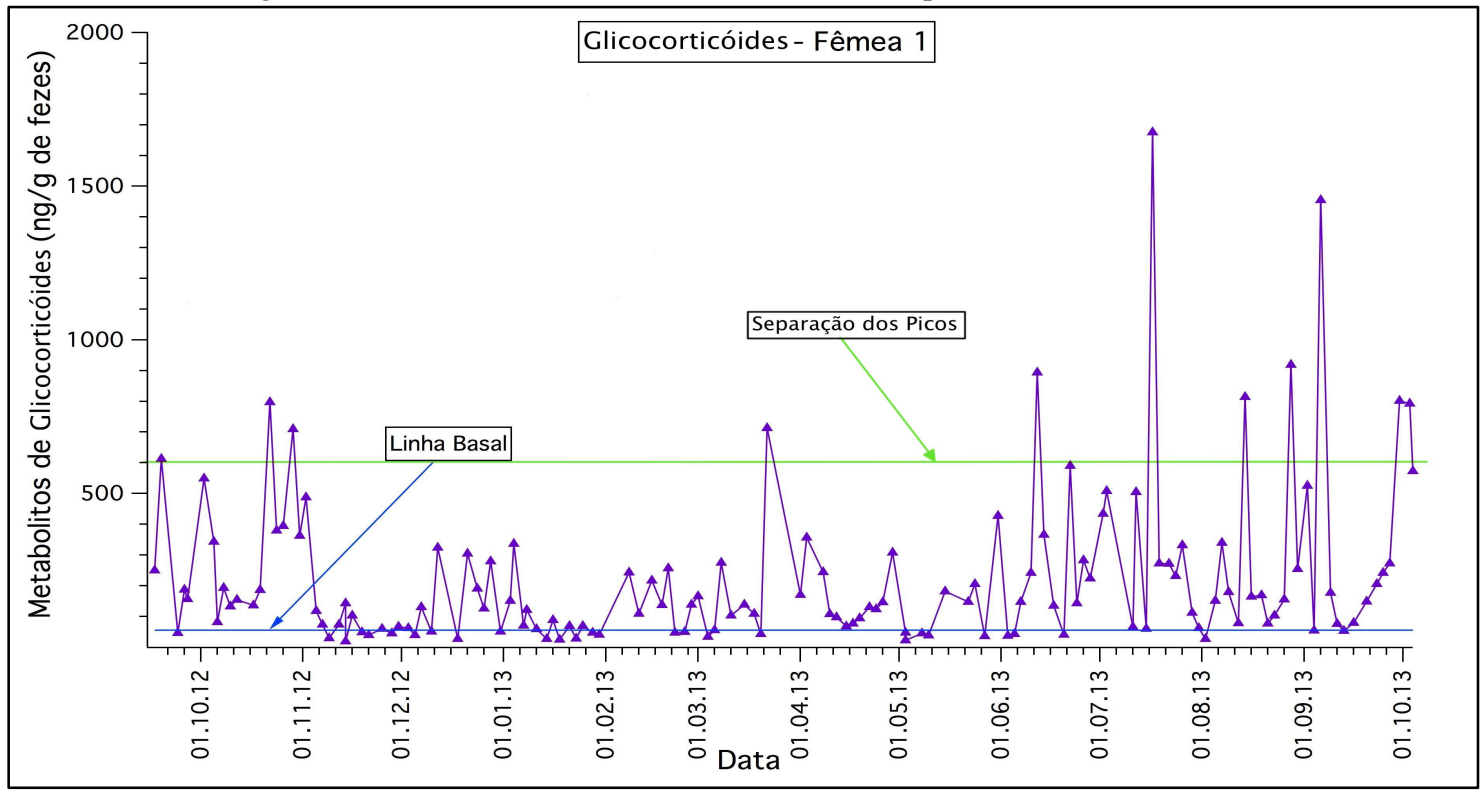


Gráfico 31 - Dosagem dos metabólitos fecais de Progesterona e Estradiol para a Fêmea 2

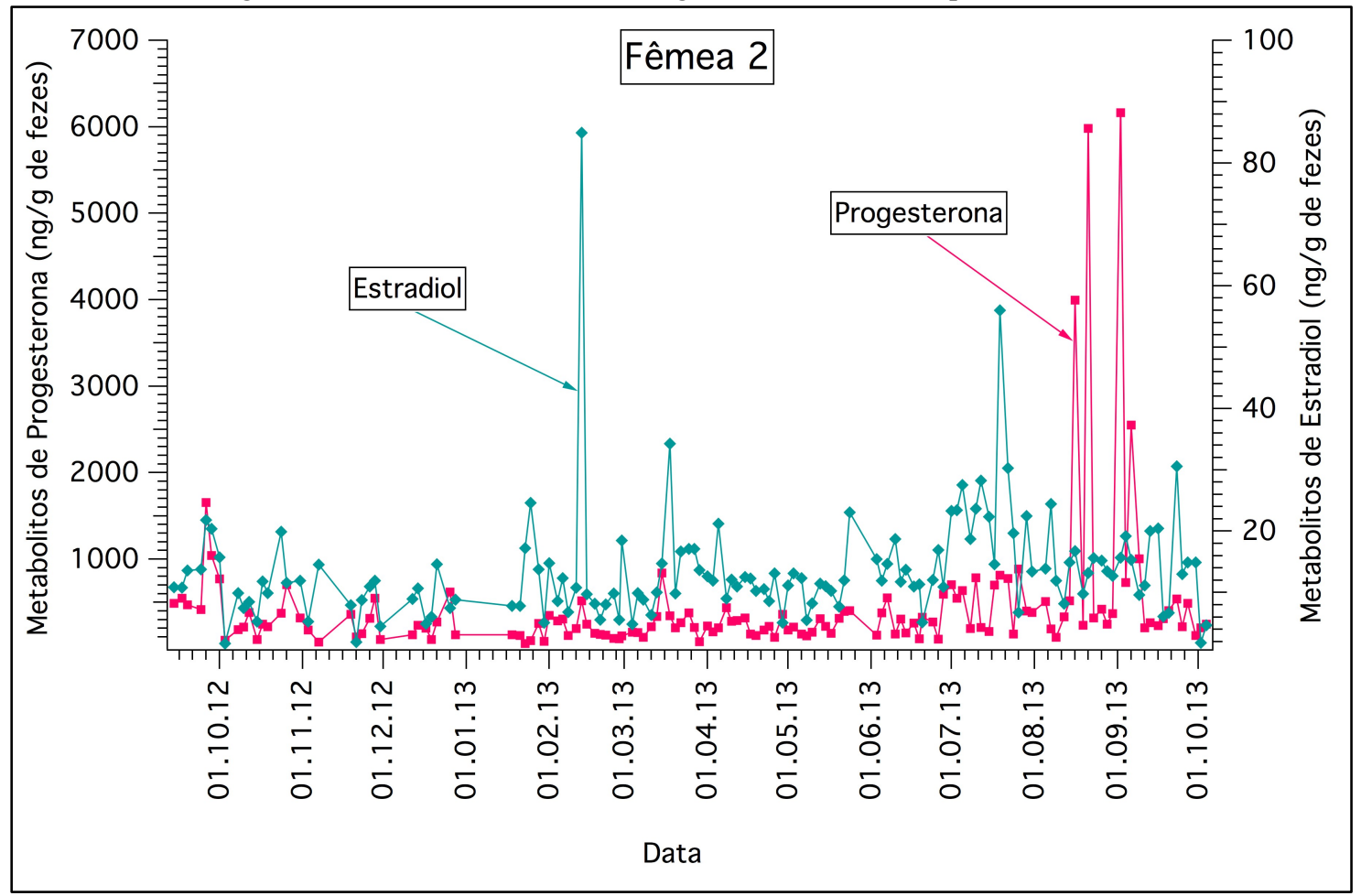

Gráfico 32 - Dosagem dos metabólitos fecais de Glicocorticóides para a Fêmea 2

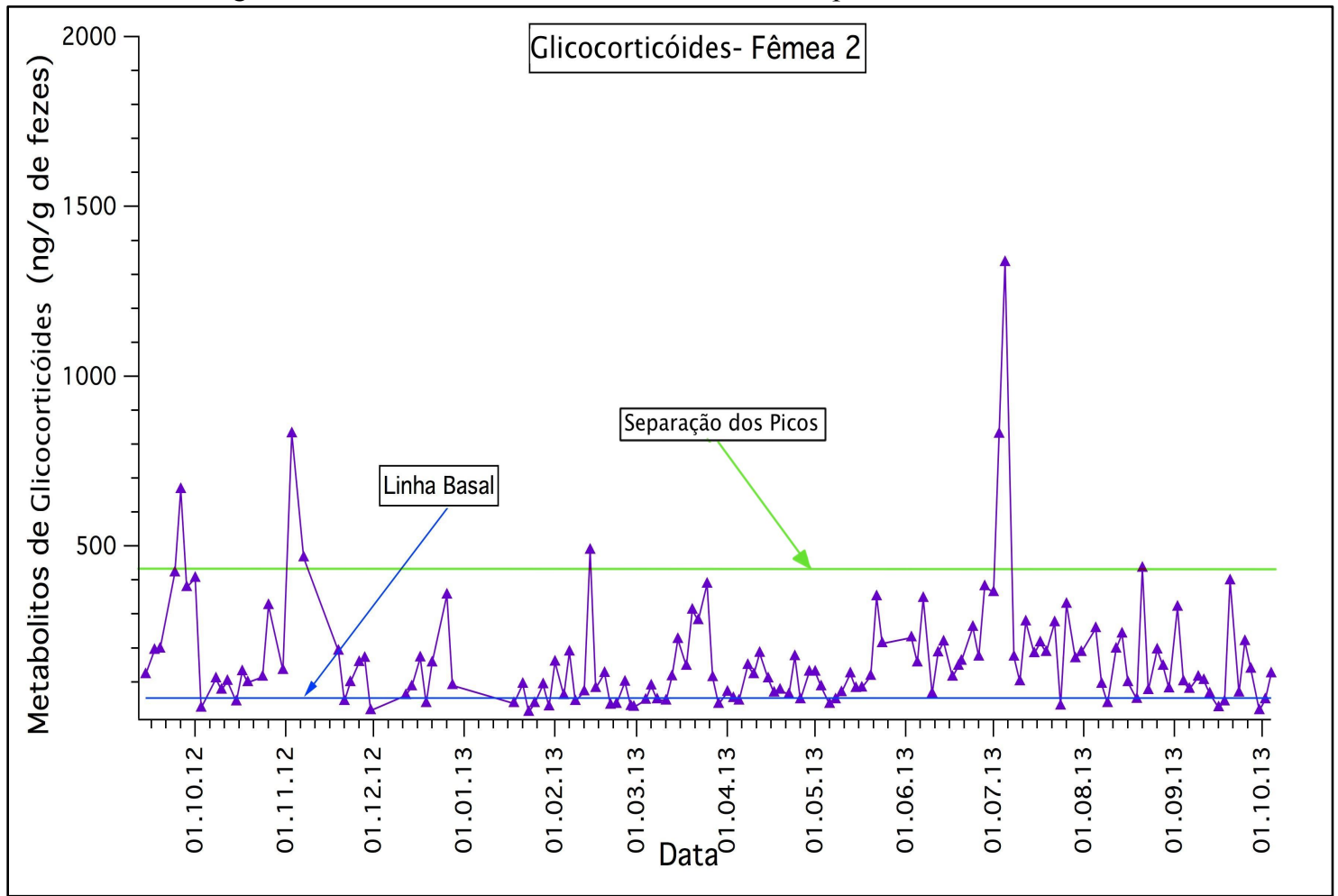


Gráfico 33 - Dosagem dos metabólitos fecais de Progesterona e Estradiol para a Fêmea 3

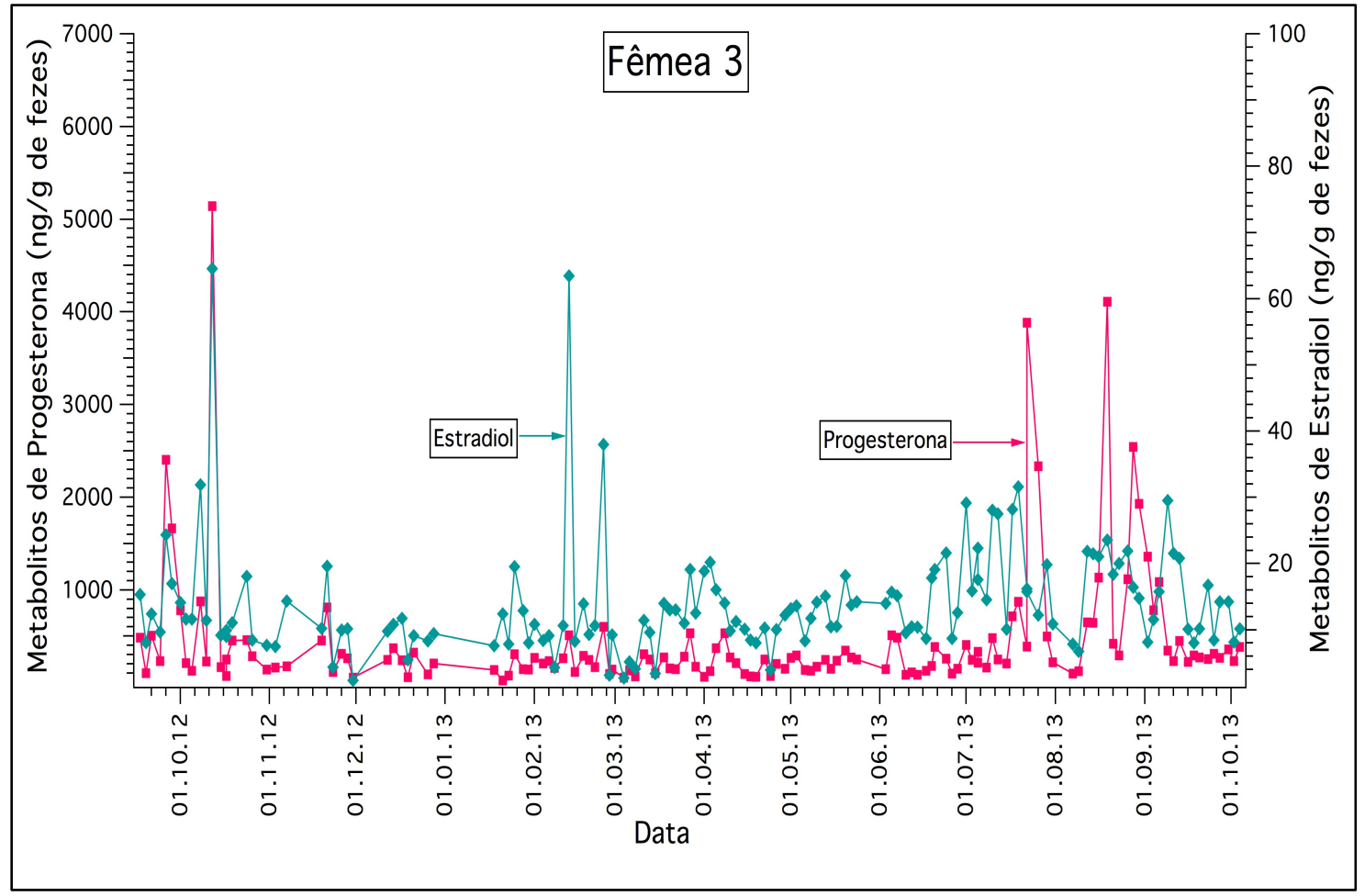

Gráfico 34 - Dosagem dos metabólitos fecais de Glicocorticóides para a Fêmea 3

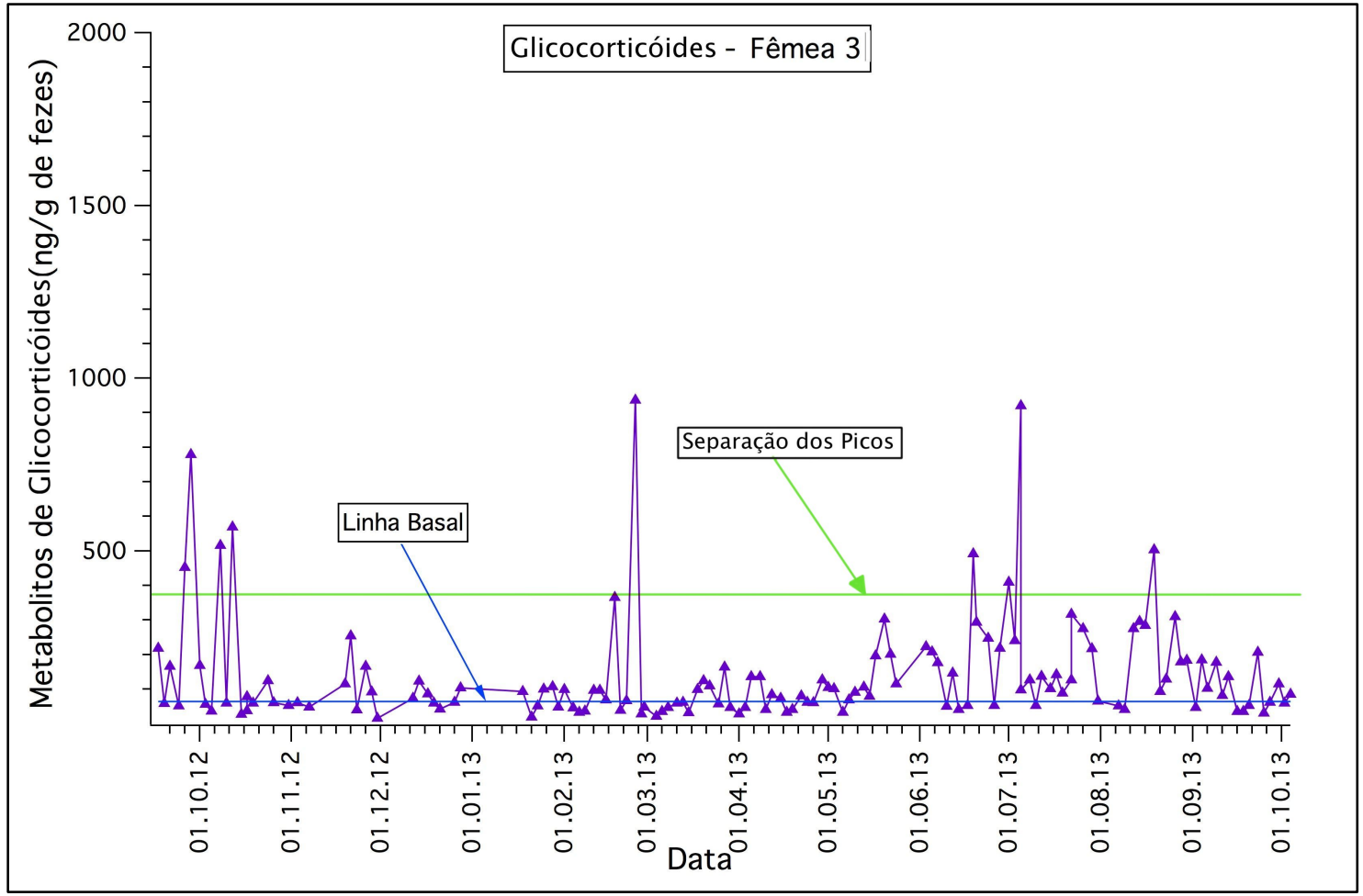


Gráfico 35 - Dosagem dos metabólitos fecais de Progesterona e Estradiol para a Fêmea 4

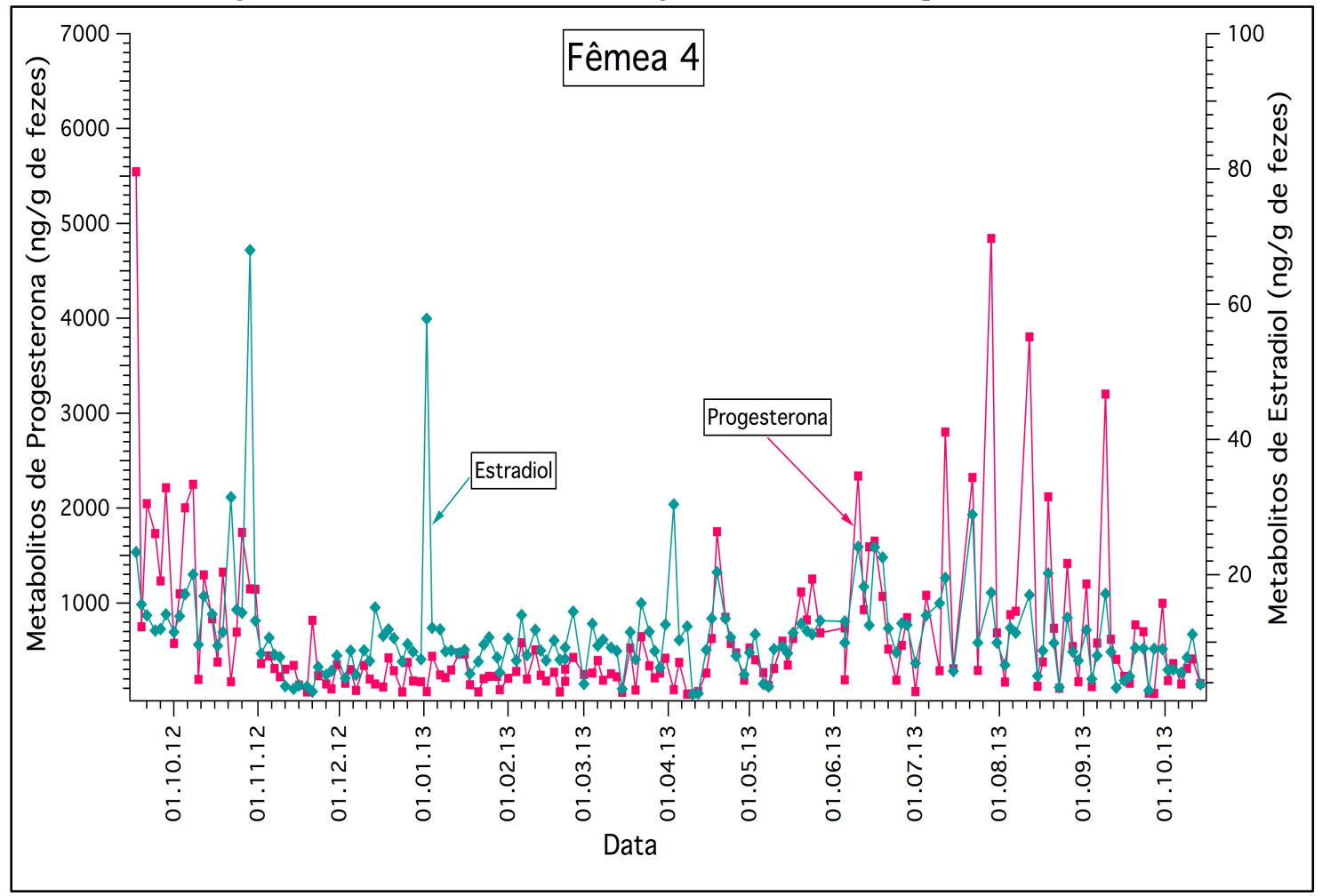

Gráfico 36 - Dosagem dos metabólitos fecais de Glicocorticóides para a Fêmea 4

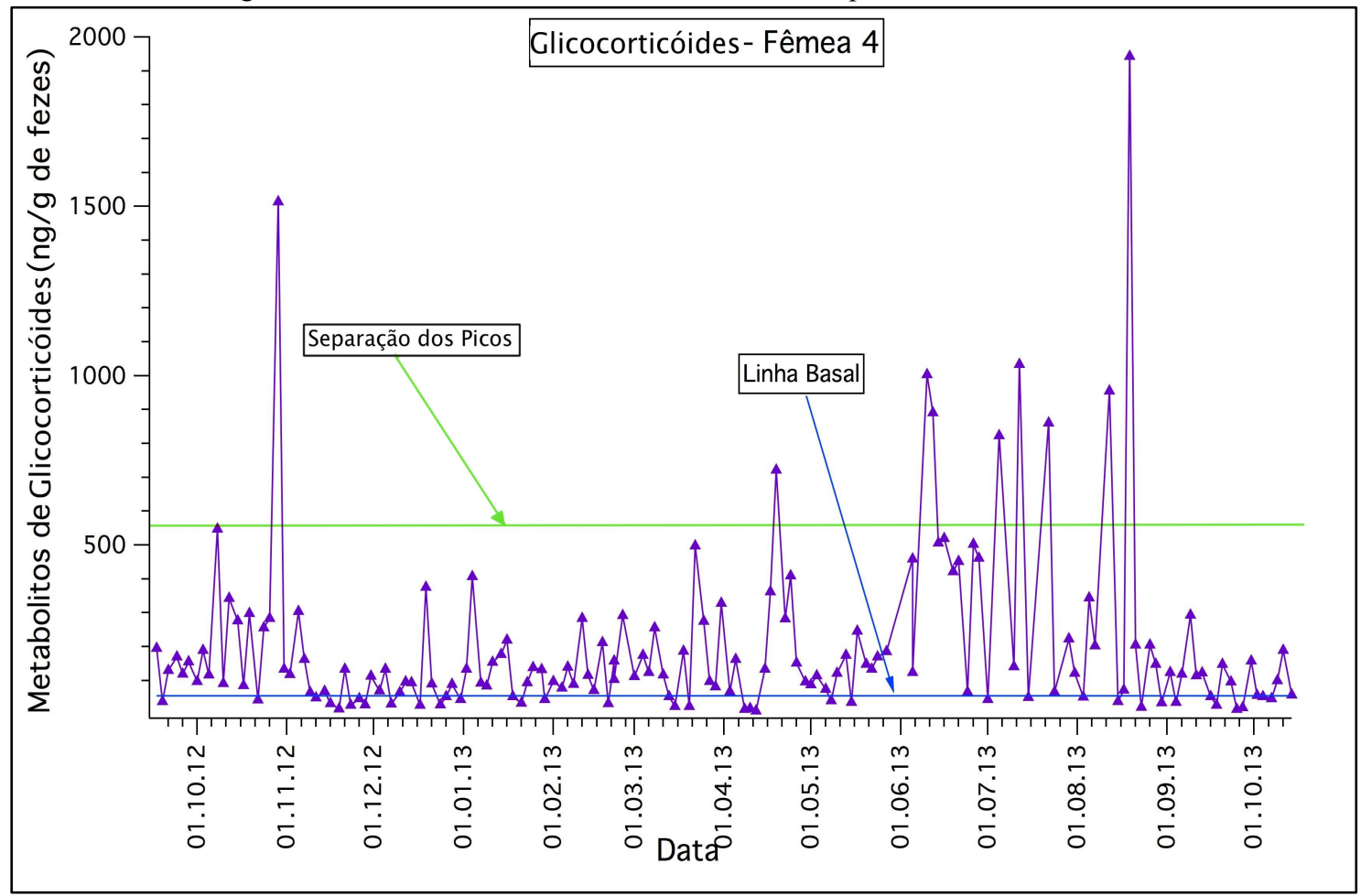


Gráfico 37 - Dosagem dos metabólitos fecais de Progesterona e Estradiol para a Fêmea 5

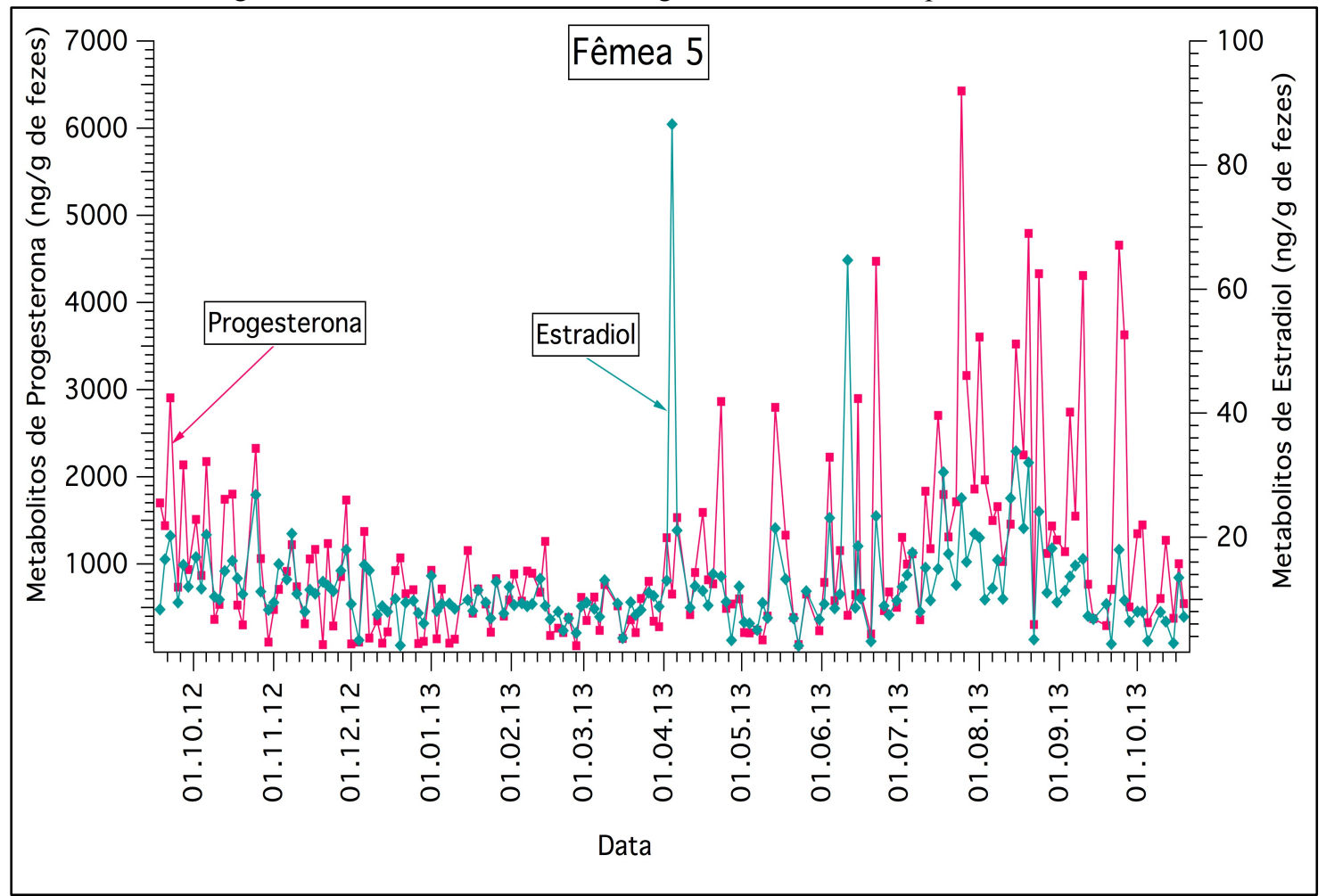

Gráfico 38 - Dosagem dos metabólitos fecais de Glicocorticóides para a Fêmea 5

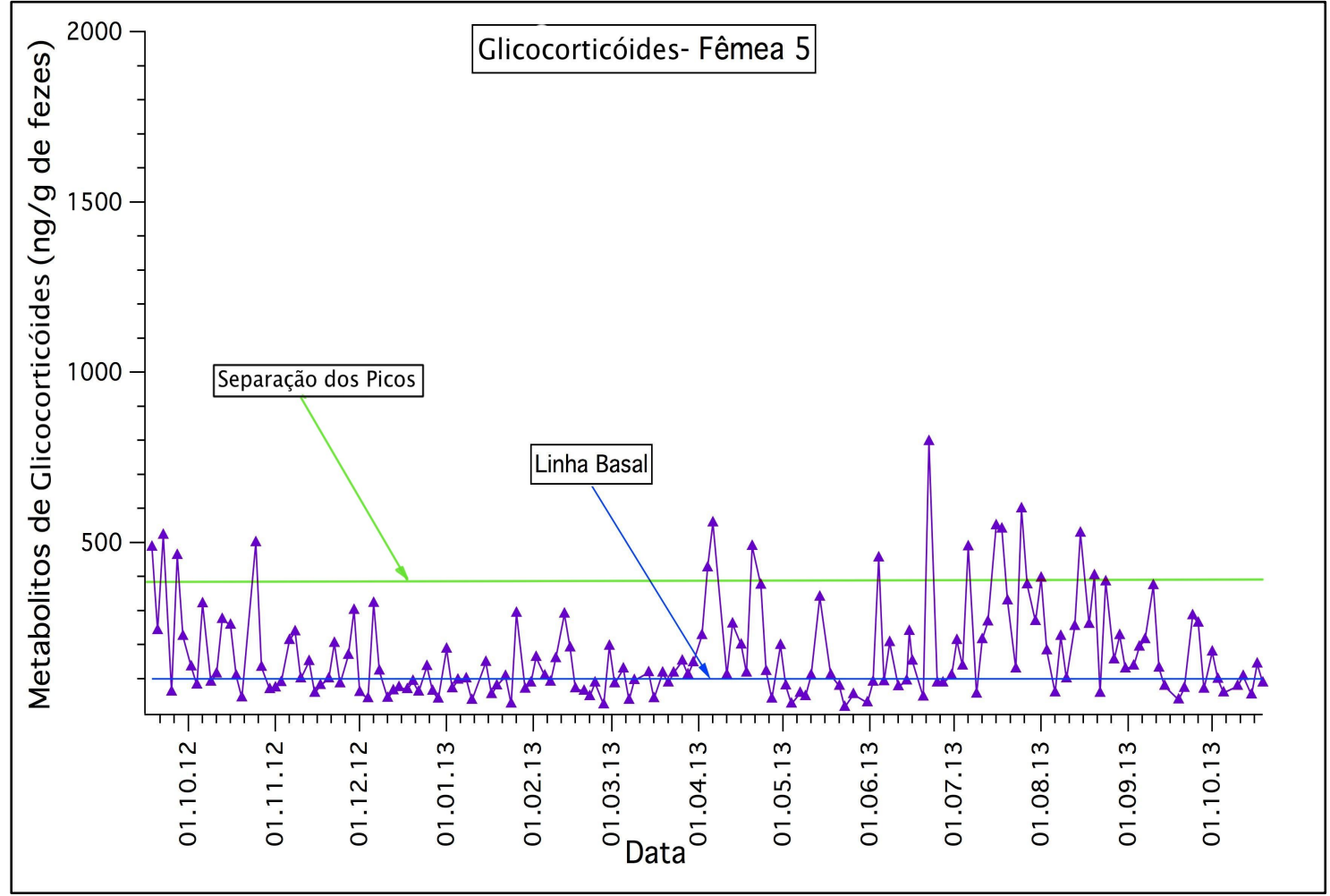


Gráfico 39 - Dosagem dos metabólitos fecais de Progesterona e Estradiol para a Fêmea 6

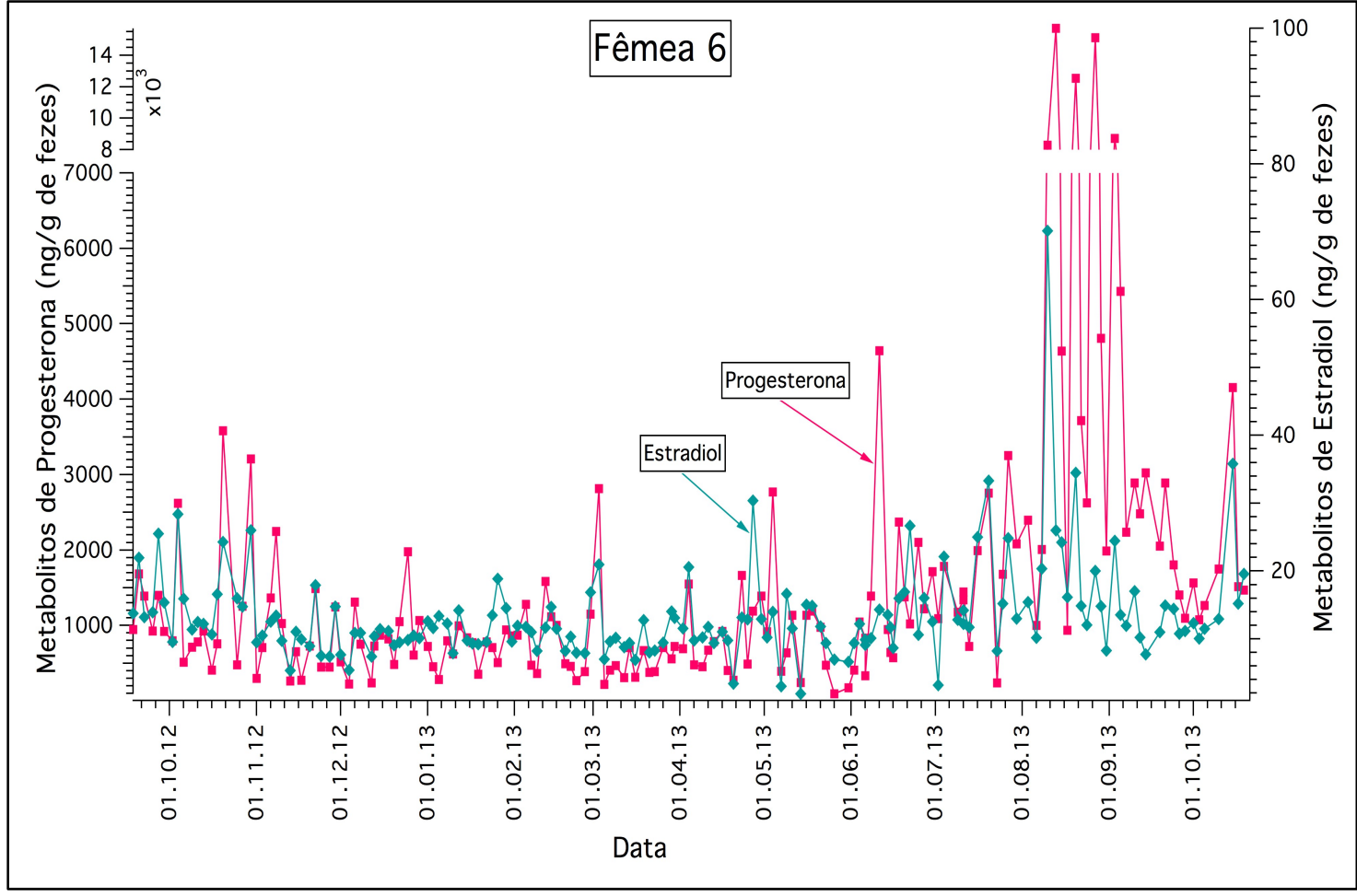

Gráfico 40 - Dosagem dos metabólitos fecais de Glicocorticóides para a Fêmea 6

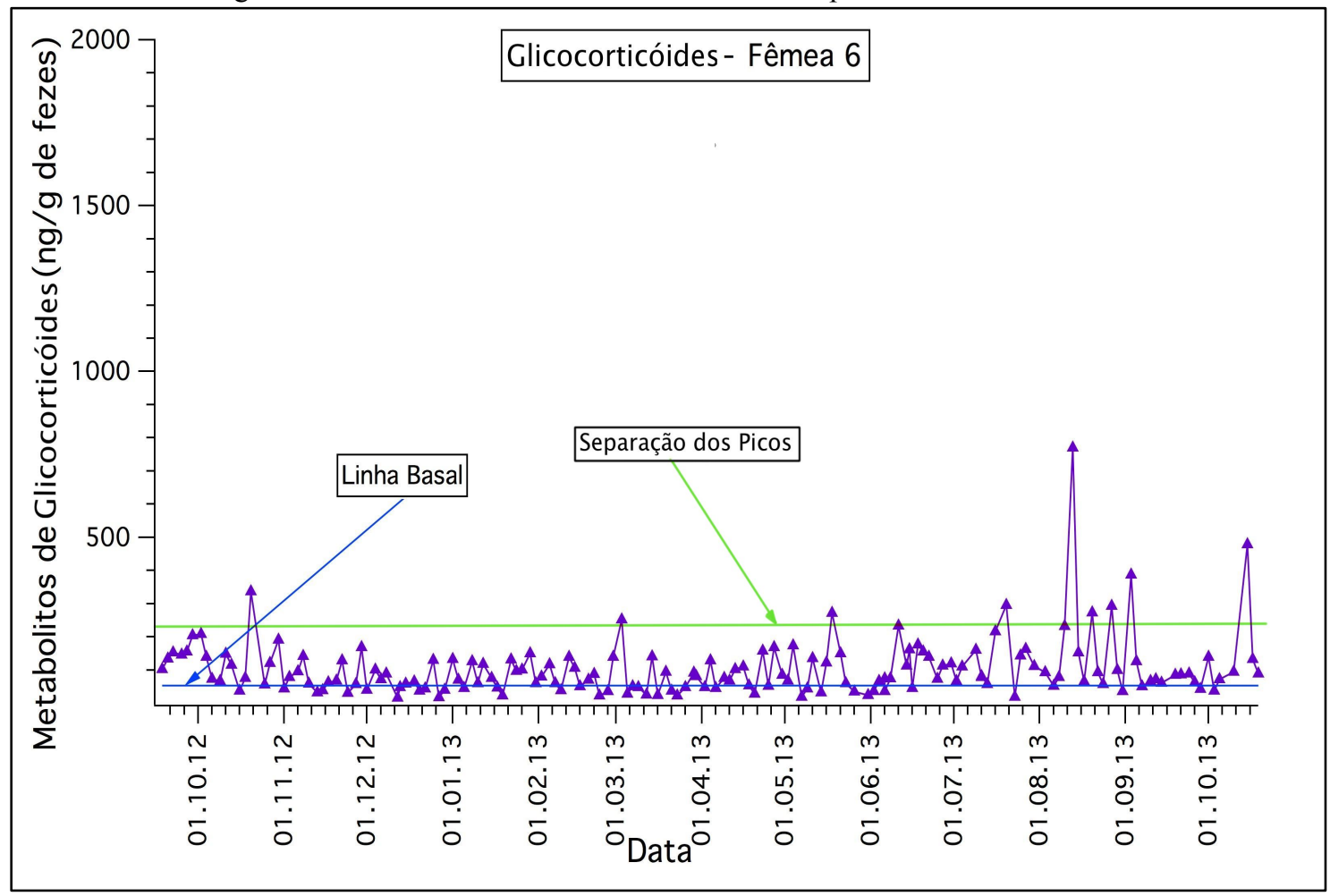


Gráfico 41 - Dosagem dos metabólitos fecais de Progesterona e Estradiol para a Fêmea 7

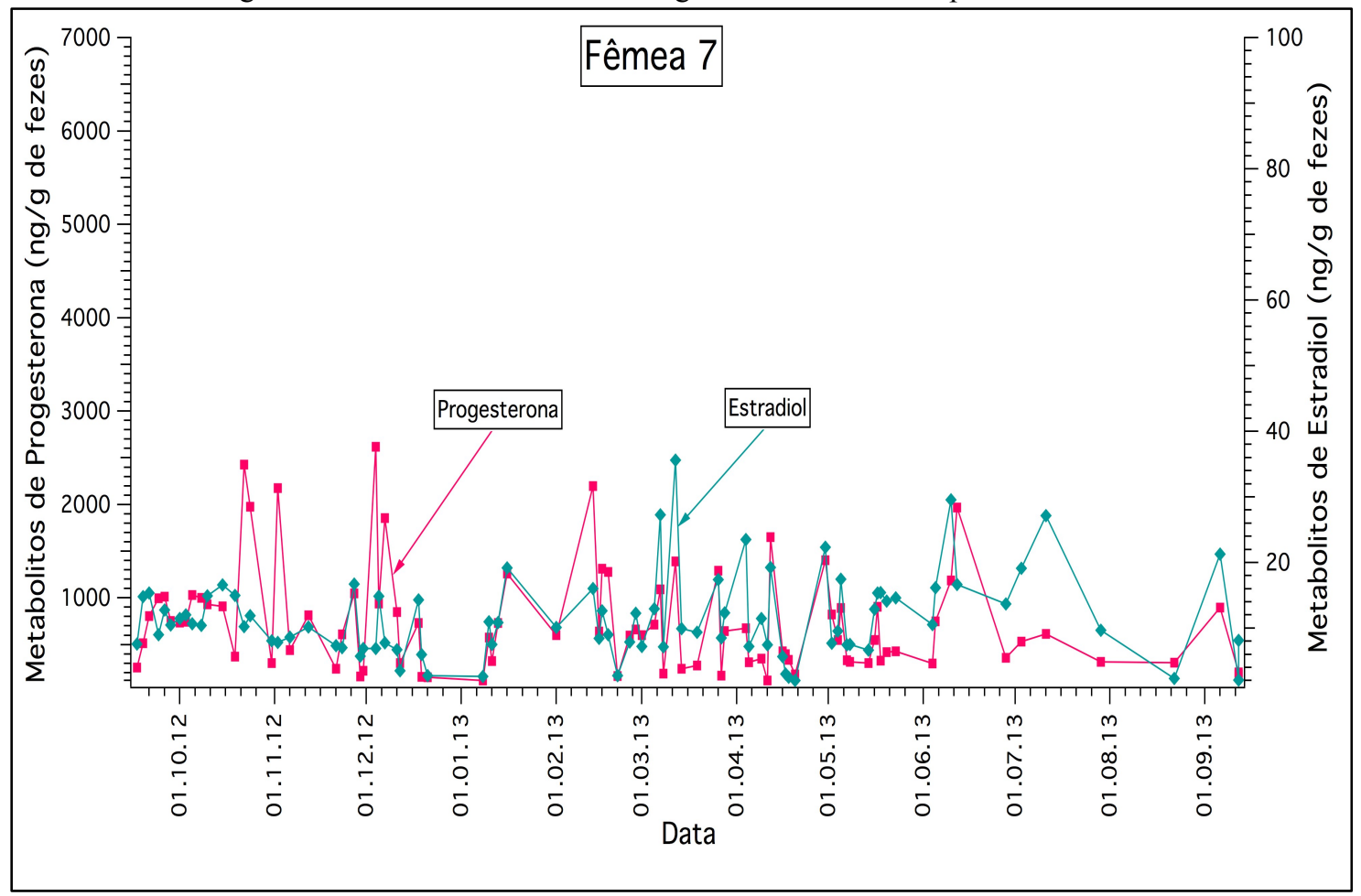

Gráfico 42 - Dosagem dos metabólitos fecais de Glicocorticóides para a Fêmea 7

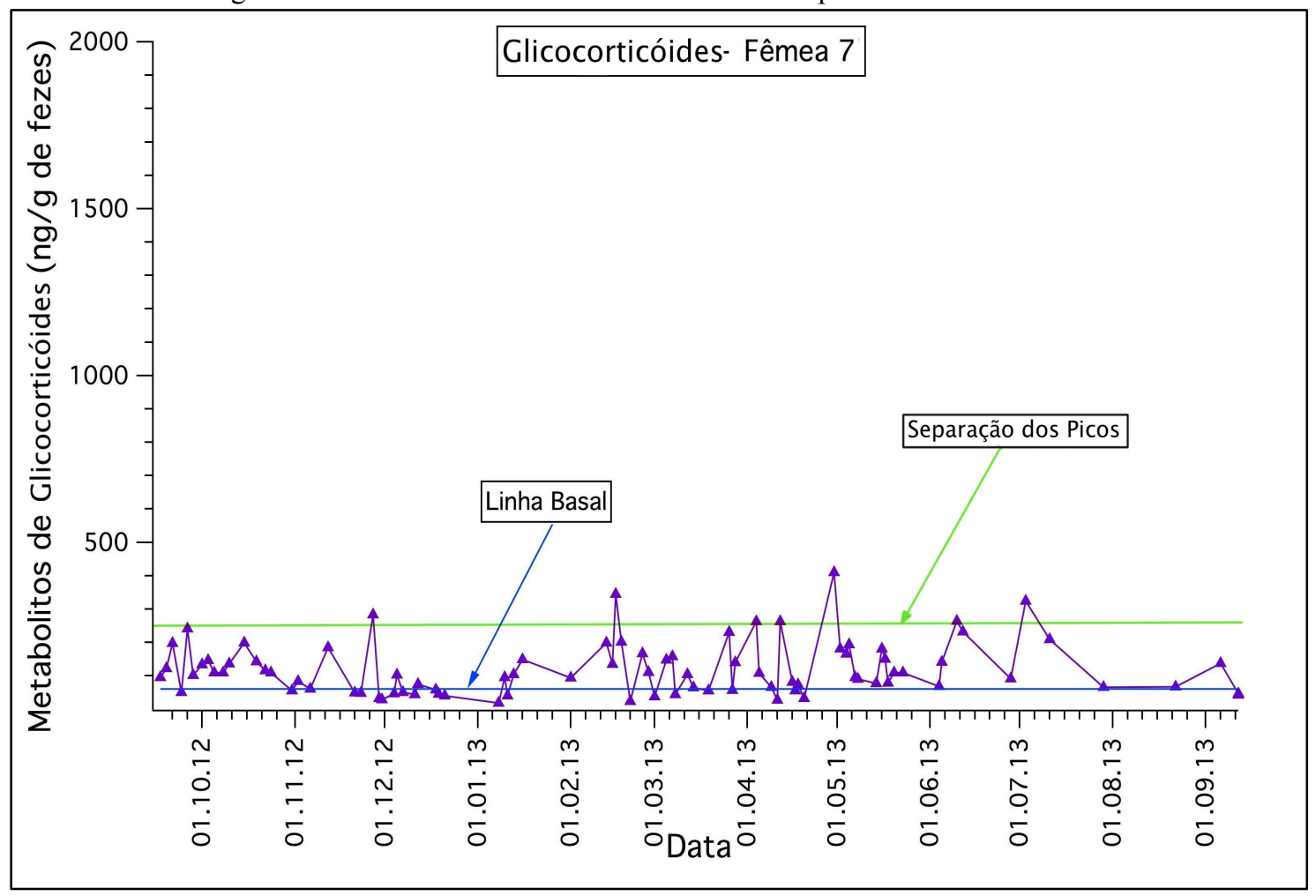


Gráfico 43 - Dosagem dos metabólitos fecais de Progesterona e Estradiol para a Fêmea 8

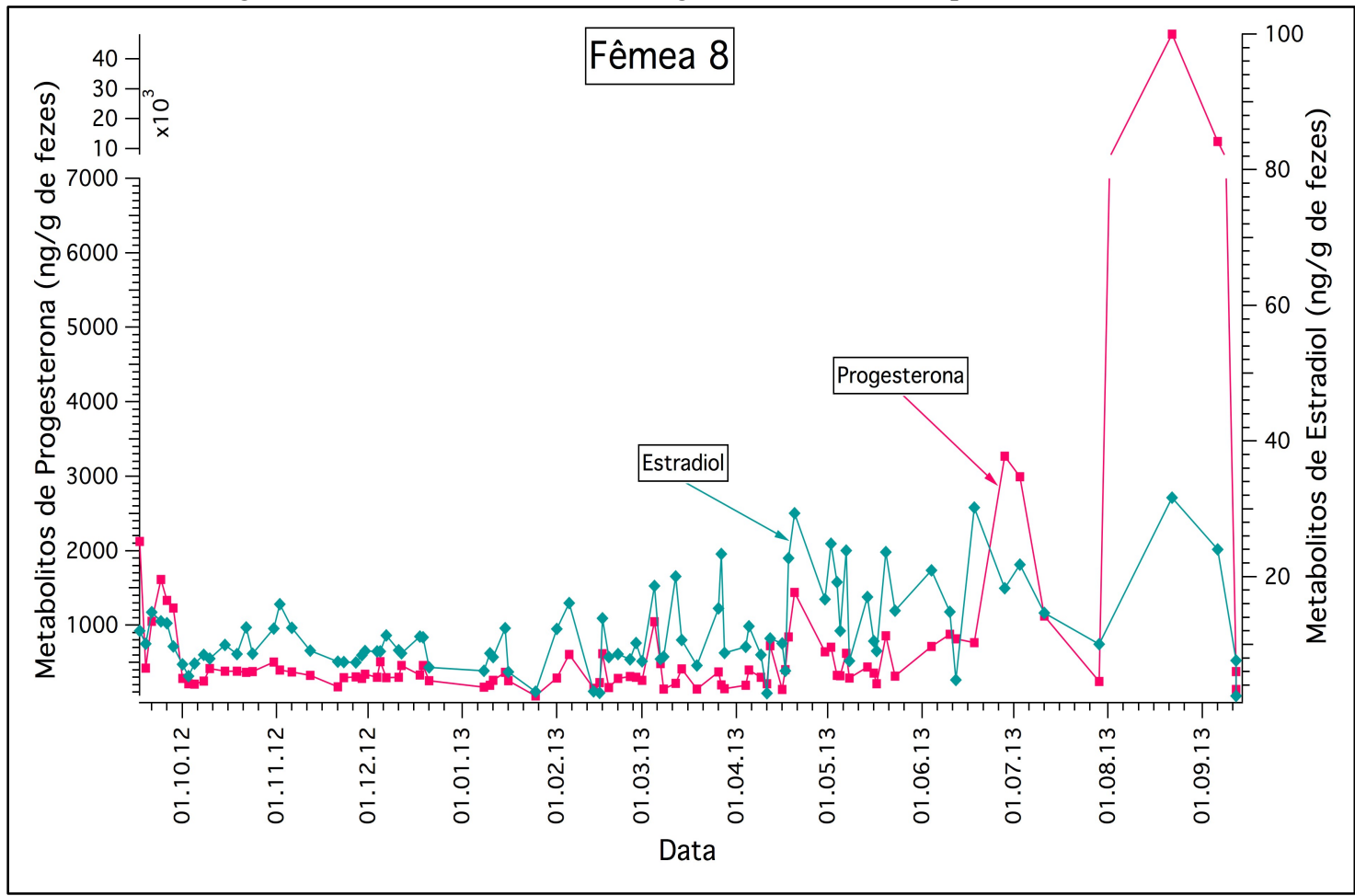

Gráfico 44 - Dosagem dos metabólitos fecais de Glicocorticóides para a Fêmea 8

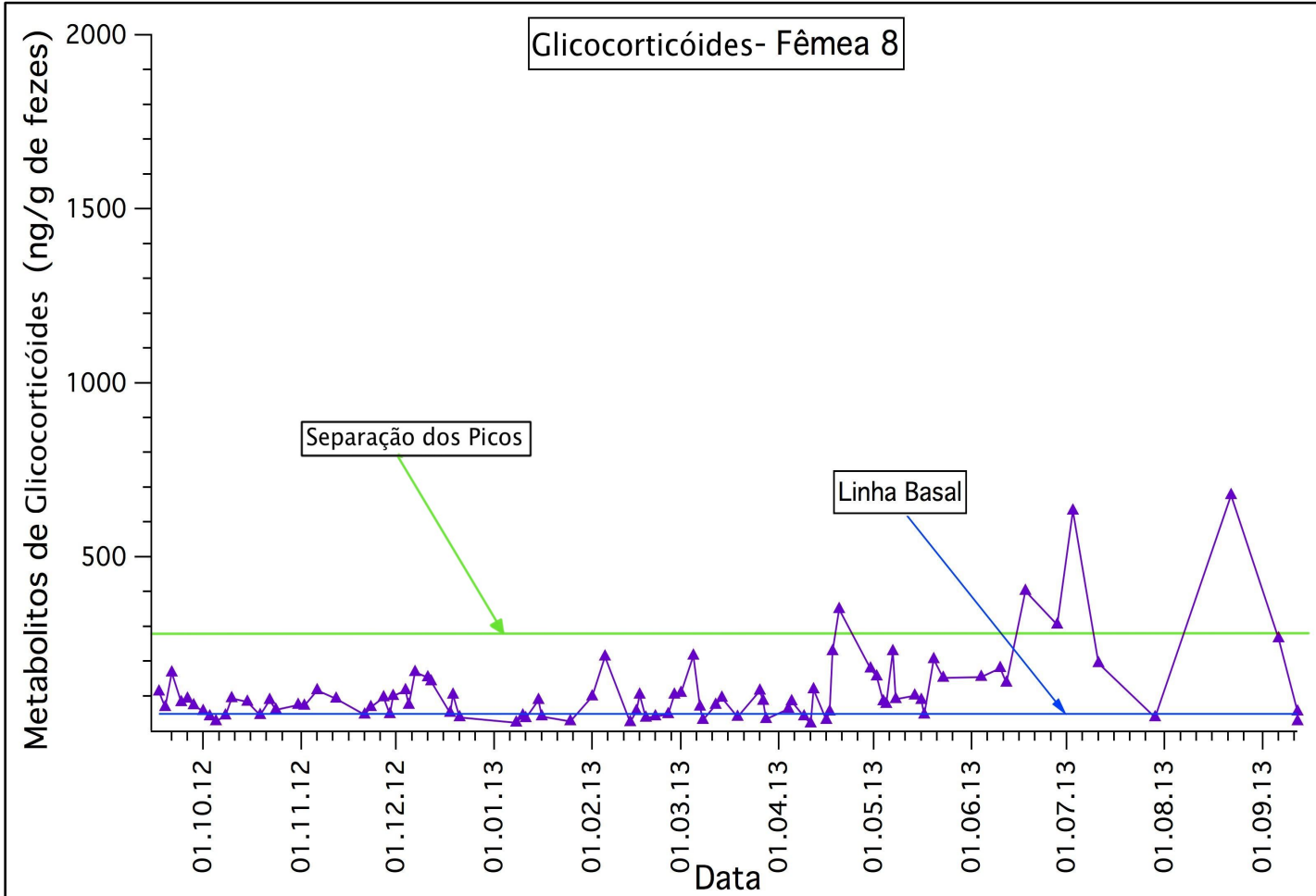




\subsection{MÉDIAS MENSAIS HORMONAIS}

A seguir temos as médias mensais com o desvio padrão para cada hormônio. Os gráficos $45,47,49,51,53,55,57$ e 59 representam as médias dos metabólitos fecais de progesterona e os gráficos $46,48,50,52,54,56,58,60$ as médias dos metabólitos fecais de estradiol. As fêmeas 7 e 8 (gráficos 57, 58, 59 e 60) não possuem as médias do mês de agosto representadas porque possuem apensa uma amostra cada para o período, não sendo possível o cálculo da média. Os gráficos 61, 62 e 63 representam as médias mensais das seis fêmeas cíclicas para cada grupo hormonal.

Gráfico 45 - Média mensal dos metabólitos fecais de Progesterona para a Fêmea 1

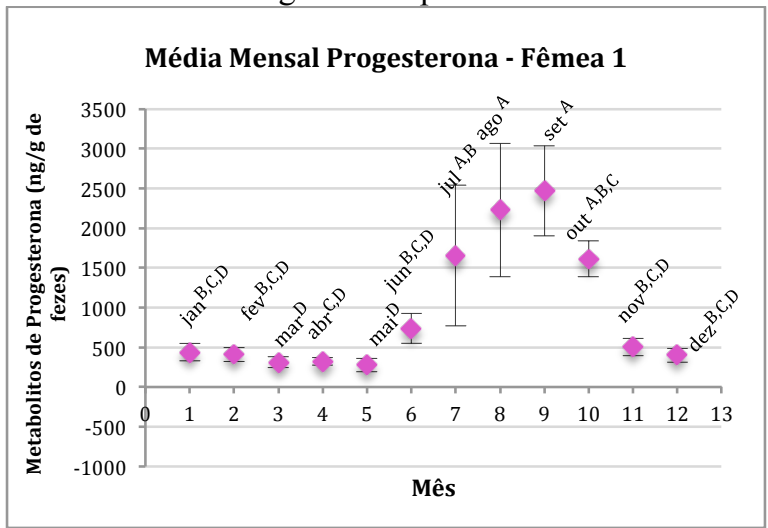

Legenda: As letras A, B, C e D representam as médias com diferença estatística. Os meses que possuem letras iguais não possuem diferença entre si $(\mathrm{p}<0,0002)$.

Gráfico 47 - Média mensal dos metabólitos fecais de Progesterona para a Fêmea 2

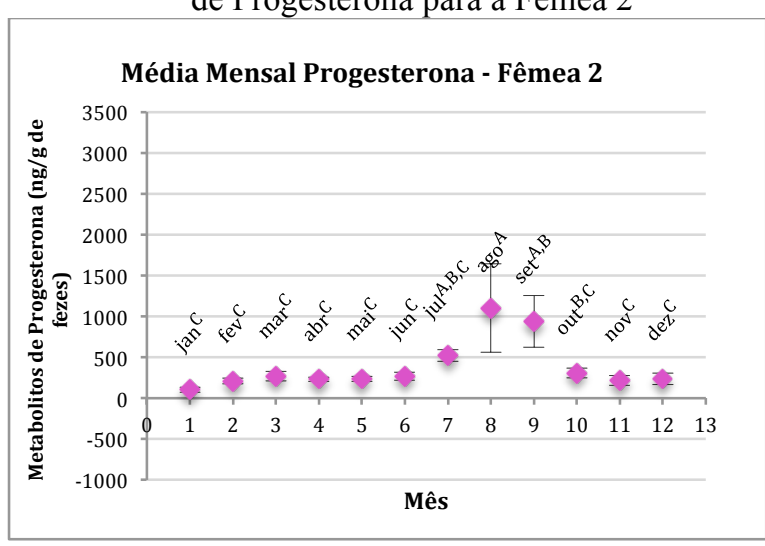

Legenda: As letras A, B e C representam as médias com diferença estatística. Os meses que possuem letras iguais não possuem diferença entre si $(\mathrm{p}<0,02)$.
Gráfico 46 - Média mensal dos metabólitos fecais de Estradiol para a Fêmea 1

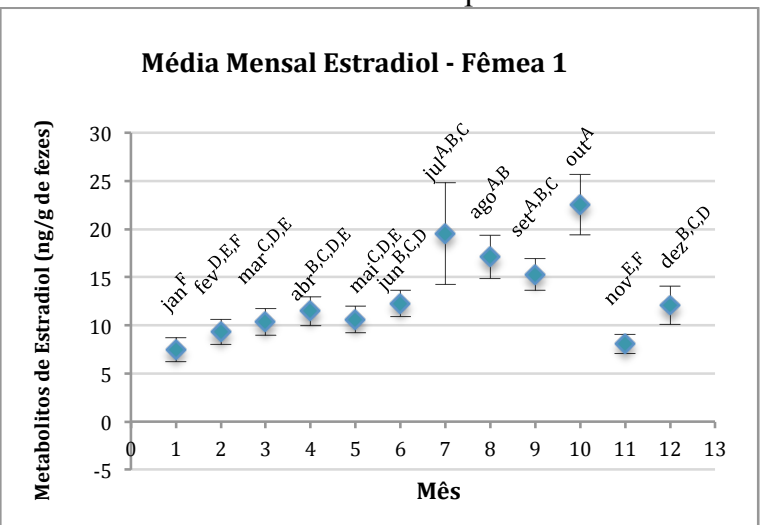

Legenda: As letras A, B, C, D, E e F representam as médias com diferença estatística. Os meses que possuem letras iguais não possuem diferença entre si $(p<0,0001)$.

Gráfico 48 - Média mensal dos metabólitos fecais de Estradiol para a Fêmea 2

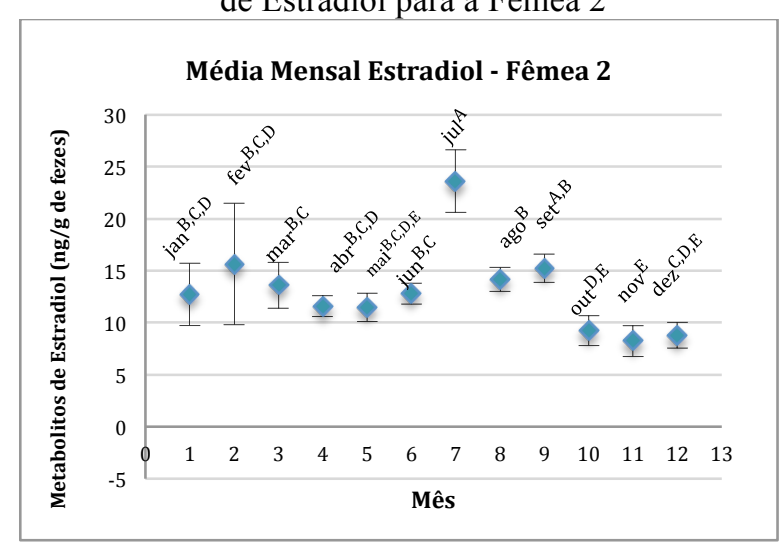

Legenda: As letras A, B, C, D e E representam as médias com diferença estatística. Os meses que possuem letras iguais não possuem diferença entre si $(\mathrm{p}<0,0001)$. 
Gráfico 49 - Média mensal dos metabólitos fecais de Progesterona para a Fêmea 3

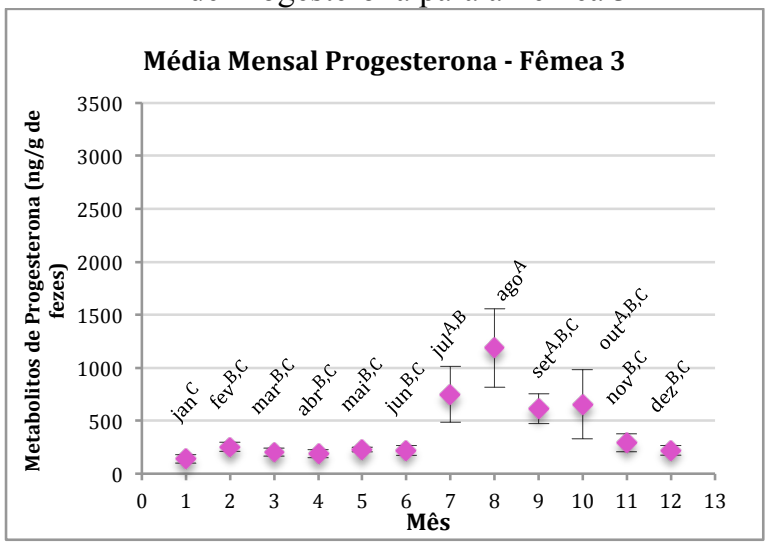

Legenda: As letras A, B e C representam as médias com diferença estatística. Os meses que possuem letras iguais não possuem diferença entre si $(p<0,006)$.

Gráfico 51 - Média mensal dos metabólitos fecais de Progesterona para a Fêmea 4

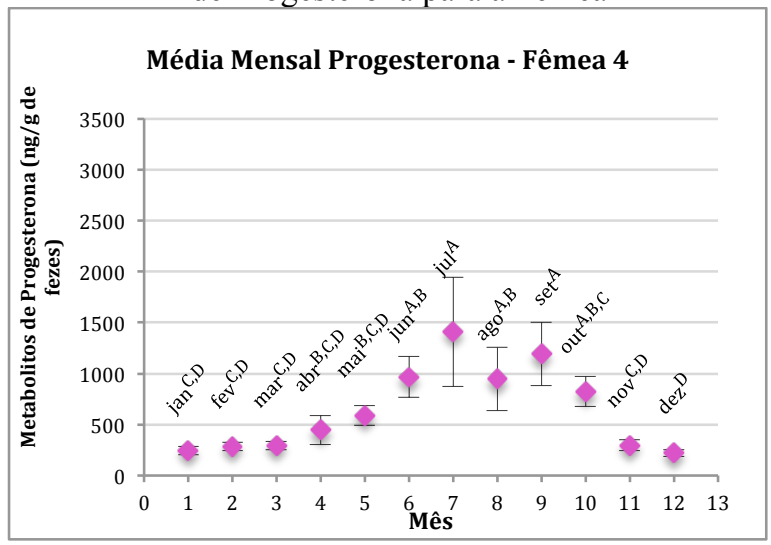

Legenda: As letras A, B, C e D representam as médias com diferença estatística. Os meses que possuem letras iguais não possuem diferença entre si $(\mathrm{p}<0,0001)$.

Gráfico 53 - Média mensal dos metabólitos fecais de Progesterona para a Fêmea 5

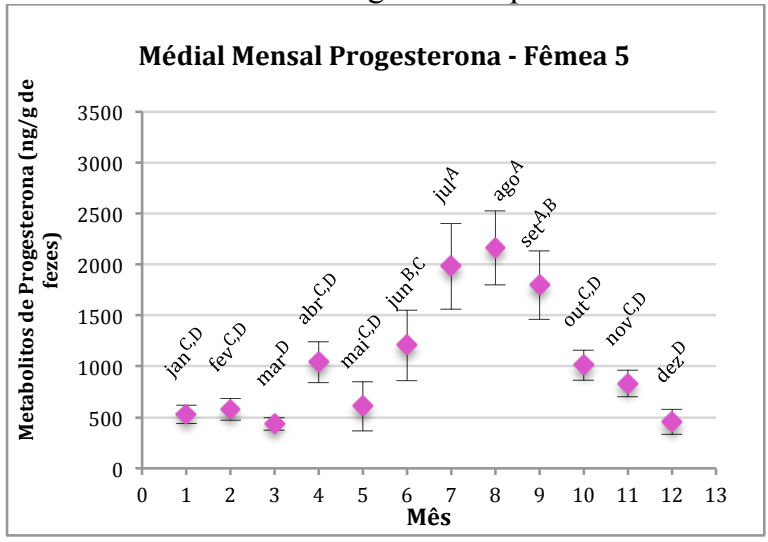

Legenda: As letras A, B, C e D representam as médias com diferença estatística. Os meses que possuem letras iguais não possuem diferença entre si $(\mathrm{p}<0,0001)$.
Gráfico 50 - Média mensal dos metabólitos fecais de Estradiol para a Fêmea 3

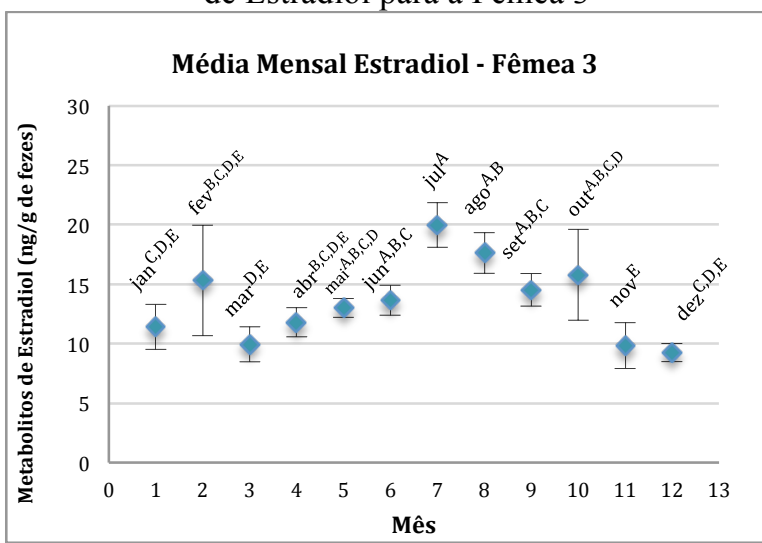

Legenda: As letras A, B, C, D e E representam as médias com diferença estatística. Os meses que possuem letras iguais não possuem diferença entre si $(p<0,001)$.

Gráfico 52 - Média mensal dos metabólitos fecais de Estradiol para a Fêmea 4

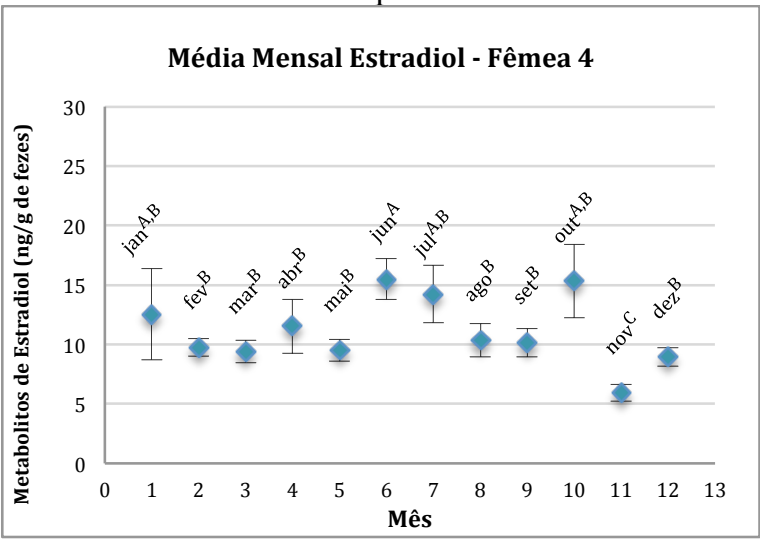

Legenda: As letras A, B e C representam as médias com diferença estatística. Os meses que possuem letras iguais não possuem diferença entre si $(\mathrm{p}<0,001)$.

Gráfico 54 - Média mensal dos metabólitos fecais de Estradiol para a Fêmea 5

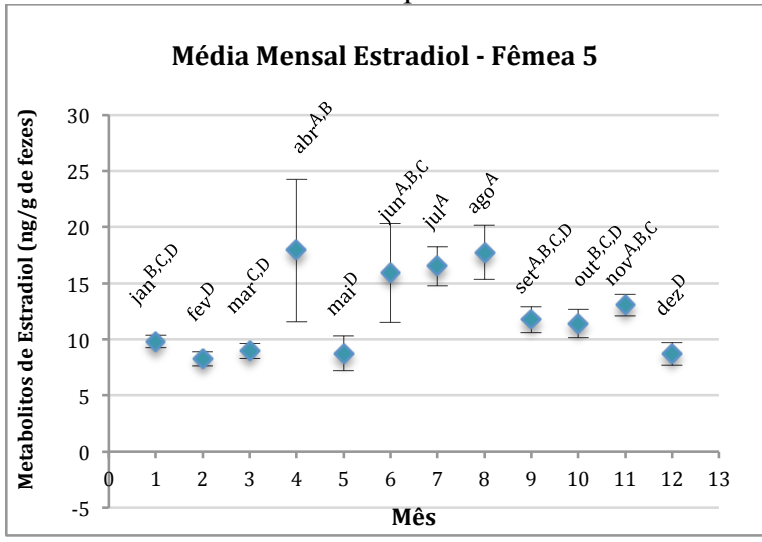

Legenda: As letras $\mathrm{A}, \mathrm{B}, \mathrm{C}$ e $\mathrm{D}$ representam as médias com diferença estatística. Os meses que possuem letras iguais não possuem diferença entre si $(\mathrm{p}<0,0006)$. 
Gráfico 55 - Média mensal dos metabólitos fecais de Progesterona para a Fêmea 6

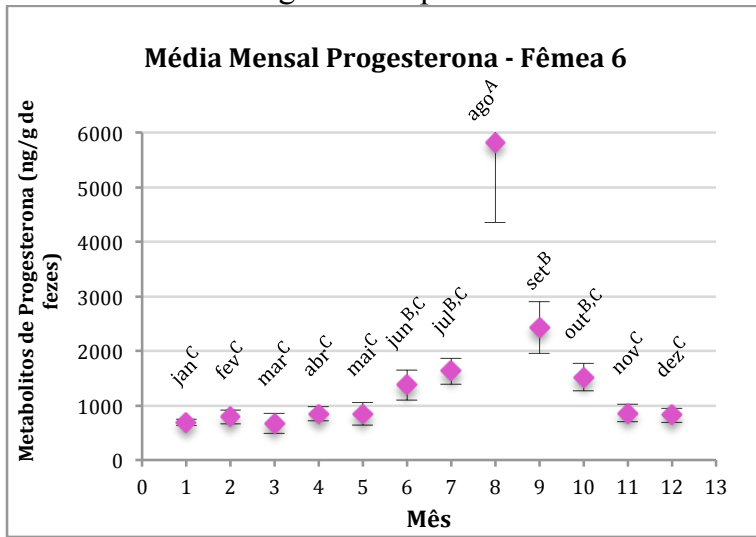

Legenda: As letras A, B e C representam as médias com diferença estatística. Os meses que possuem letras iguais não possuem diferença entre si $(p<0,0001)$.

Gráfico 57 - Média mensal dos metabólitos fecais de Progesterona para a Fêmea 7

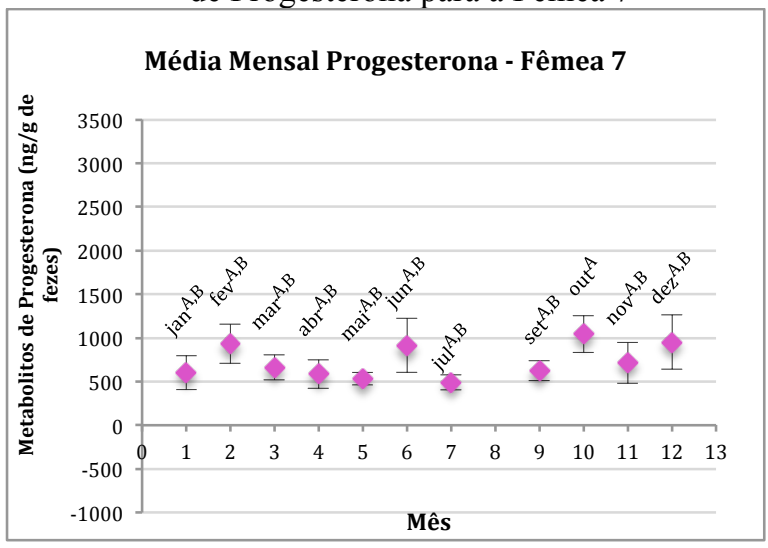

Legenda: As letras A e B representam as médias com diferença estatística. Os meses que possuem letras iguais não possuem diferença entre si $(p<0,5)$.

Gráfico 59 - Média mensal dos metabólitos fecais de Progesterona para a Fêmea 8

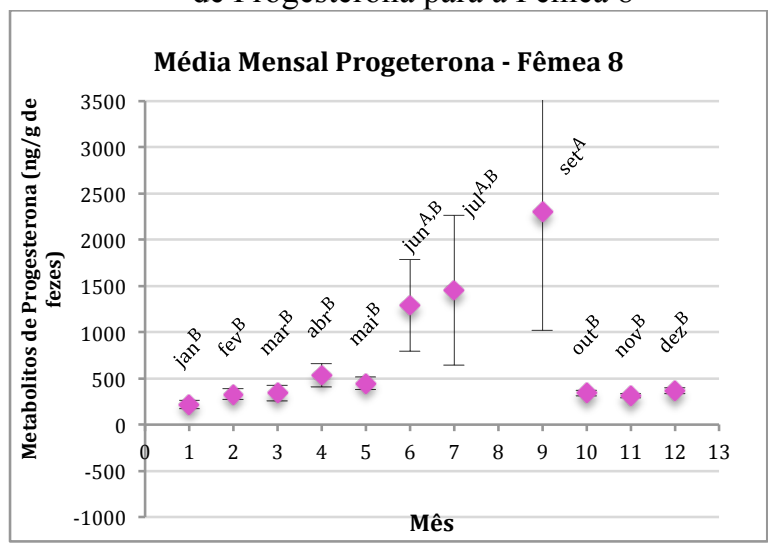

Legenda: As letras A e B representam as médias com diferença estatística. Os meses que possuem letras iguais não possuem diferença entre si $(p<0,0001)$.
Gráfico 56 - Média mensal dos metabólitos fecais de Estradiol para a Fêmea 6

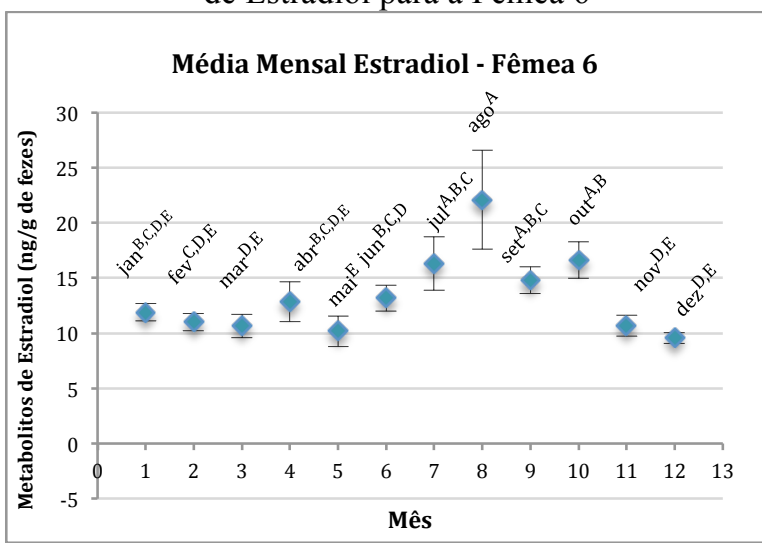

Legenda: As letras A, B, C, D e E representam as médias com diferença estatística. Os meses que possuem letras iguais não possuem diferença entre si $(\mathrm{p}<0,0001)$.

Gráfico 58 - Média mensal dos metabólitos fecais de Estradiol para a Fêmea 7

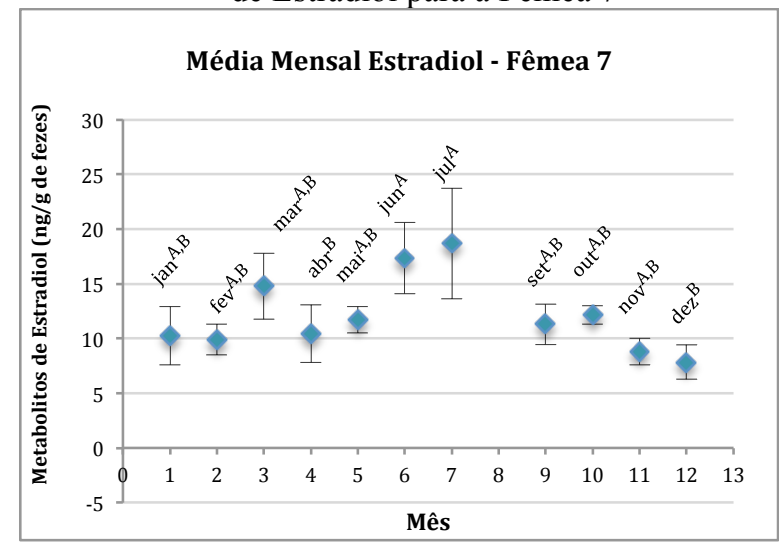

Legenda: As letras A e B representam as médias com diferença estatística. Os meses que possuem letras iguais não possuem diferença entre si $(\mathrm{p}<0,02)$.

Gráfico 60 - Média mensal dos metabólitos fecais de Estradiol para a Fêmea 8

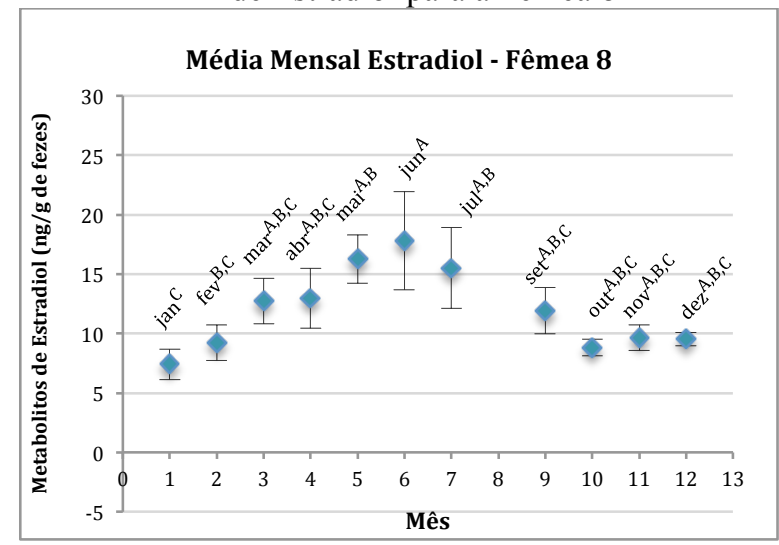

Legenda: As letras A, B e C representam as médias com diferença estatística. Os meses que possuem letras iguais não possuem diferença entre si $(p<0,01)$. 
Gráfico 61 - Média mensal dos metabólitos fecais de Estradiol para as fêmeas cíclicas (Fêmeas 1, 2, 3, 4, 5 e 6)

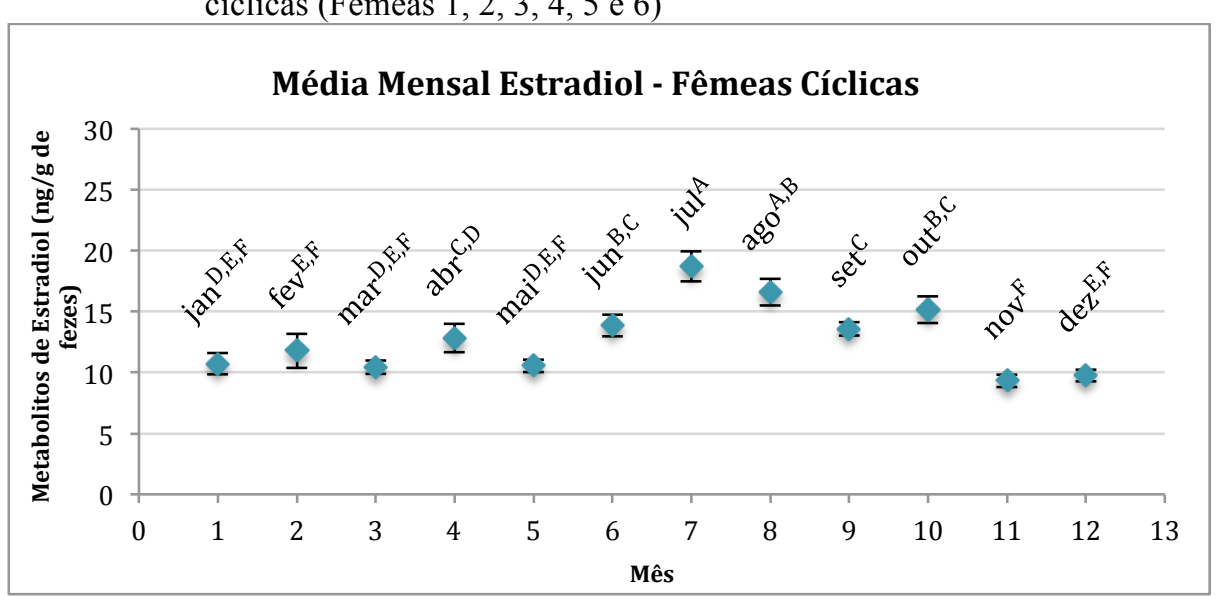

Legenda: As letras A, B, C, D, E e F representam as médias que possuem diferença estatística. Os meses que possuem letras iguais não possuem diferença entre si $(\mathrm{p}<0,0001)$.

Gráfico 62 - Média mensal dos metabólitos fecais de Progesterona para as fêmeas cíclicas (Fêmeas 1, 2, 3, 4, 5 e 6)

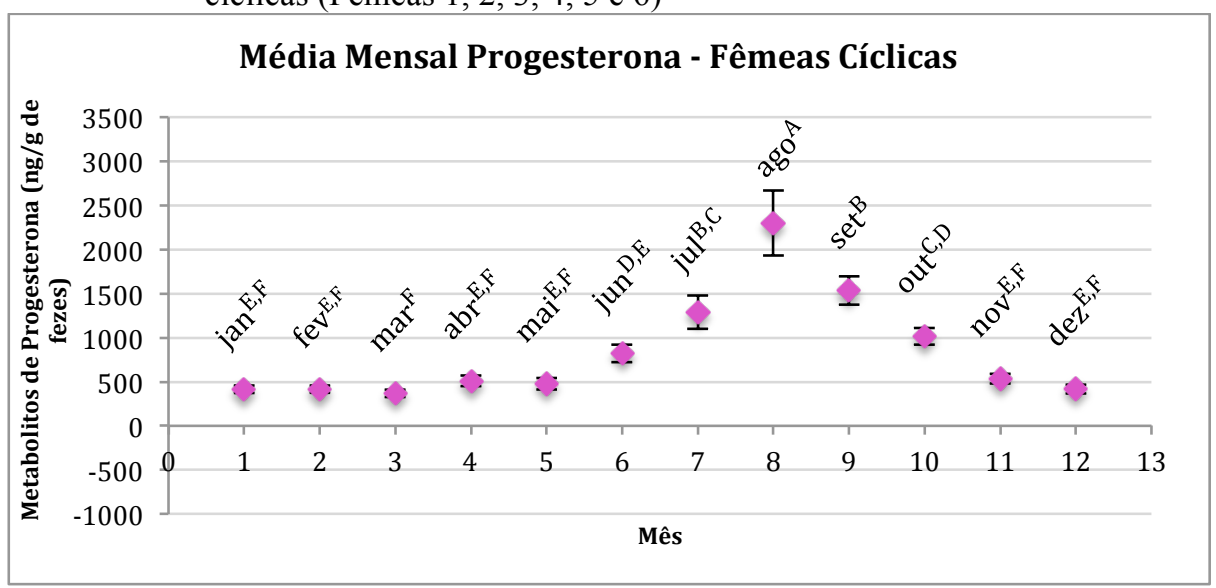

Legenda: As letras A, B, C, D, E e F representam as médias que possuem diferença estatística. Os meses que possuem letras iguais não possuem diferença entre si $(p<0,0001)$.

Gráfico 63 - Média mensal dos metabólitos fecais de Glicocorticóides para as fêmeas cíclicas (Fêmeas 1, 2, 3, 4, 5 e 6)

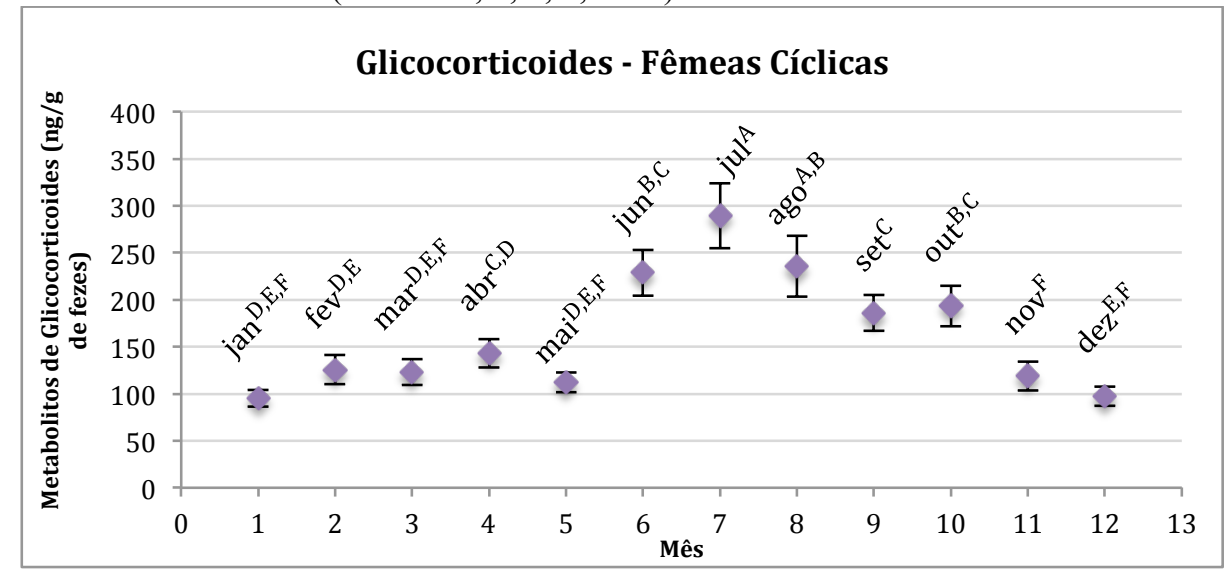

Legenda: As letras A, B, C, D, E e F representam as médias que possuem diferença estatística. Os meses que possuem letras iguais não possuem diferença entre si $(\mathrm{p}<0,0001)$. 


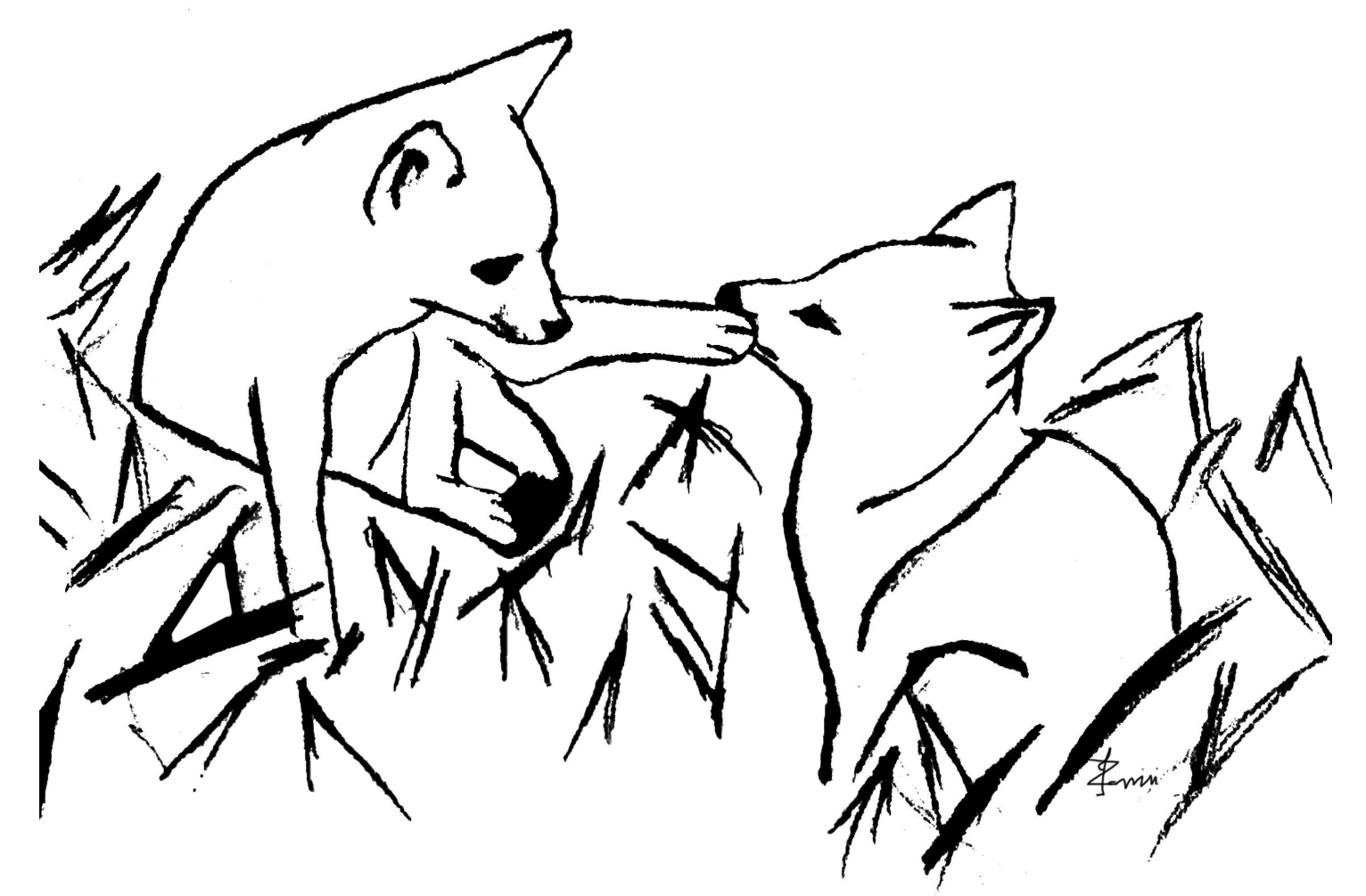

Discussão 


\section{DISCUSSÃO}

\subsection{VALIDAÇÃO FISIOLÓGICA DA TÉCNICA}

A validação fisiológica foi bem sucedida nas fêmeas 5 e 6 , como demonstram os gráficos 3 e 4 . Houve um pico de metabólitos fecais de progesterona e estradiol cerca de 48 horas após a aplicação do GnRH. A fêmea 6, não defecou no dia onde daria 48 horas da aplicação do GnRH, portanto podemos sugerir que as dosagens nessa fêmea correspondem a descida do pico, com 72 horas, perdendo os valores mais altos com 48 horas.

Em todas as fêmeas submetidas a validação fisiológica com $\mathrm{GnRH}$, foi utilizado o mesmo volume do fármaco, pois os pesos reais dos animais não eram conhecidos, o que pode ter ocasionado a aplicação de diferentes doses em cada indivíduo.

Nas fêmeas 2 e 3 houve pequena estimulação hormonal sem a caracterização do pico, na dose aplicada, como demonstram os gráficos 1 e 2 . Mesmo não havendo o peso real de cada indivíduo, a fêmea 3 possuía claramente uma massa corporal maior do que as outras fêmeas, o que indica que a dose de GnRH aplicada foi menor nesse indivíduo, o que pode justificar a não estimulação hormonal. Devido ao fato de ainda não haver uma dose padrão para a estimulação hormonal nessa espécie, é possível que esses indivíduos necessitassem de uma dose maior de GnRH para haver o estímulo hormonal adequado.

Além da validação fisiológica bem sucedida, houve também a validação biológica, pois 6 fêmeas apresentaram o mesmo perfil de excreção hormonal ao longo do ano, com períodos bem definidos de maior atividade hormonal reprodutiva.

6.2 PERFIL DA EXCREÇÃO HORMONAL DOS METABÓLITOS FECAIS DE PROGESTERONA, ESTRADIOL E GLICOCORTICÓIDES

\subsubsection{Concentrações de Progesterona e Estradiol}


Os Perfis de excreção dos metabólitos fecais de progesterona e estradiol nas fêmeas 1 a 6 são muito semelhantes entre si, com períodos de atividade reprodutiva muito bem marcados ao longo do ano. No perfil desses indivíduos podemos observar que a maior concentração dos picos de estradiol, que representam uma maior atividade de maturação folicular, coincidem com a maior concentração dos picos de progesterona, que sinalizam a ocorrência de ciclos ovulatórios, em um período específico do ano, independentemente da instituição e condição onde esses indivíduos estão, e da presença ou não de um macho no mesmo recinto.

Avaliando as médias mensais desses indivíduos juntos, temos que para metabólitos fecais de progesterona, o mês de agosto é o mês com maior diferença estatística, seguido de setembro e julho. Para os metabólitos fecais de estradiol, julho e agosto foram os meses de maior diferença estatística, seguidos de junho e setembro. Para esses seis indivíduos, o período de atividade reprodutiva ocorre nos meses de julho, agosto e setembro (Gráficos 29, 31, 33, 35, 37 e 39). Nesses meses ocorrem os principais picos de estradiol seguidos do pico de progesterona o que caracterizam a ocorrência da ovulação, que ocorre mais de uma vez dentro desse período.

Nos demais nove meses do ano, apesar de haver variações nas dosagens dos metabólitos fecais de progesterona e de estradiol acima do valor basal calculado, representado nos gráficos de 13 a 28, essas variações podem possivelmente representar atividade folicular e ovariana, mas são insuficientes para promover a ovulação.

Os picos de estradiol seguidos de picos de progesterona caracterizam eventos ovulatórios. Sendo assim, podemos observar que das 6 fêmeas cíclicas, pelo menos 4 indivíduos (fêmeas 1, 3, 4 e 5) apresentaram mais de um evento ovulatório no período de maior atividade ovariana. Deve-se considerar ainda que devido ao método de coleta (3 vezes na semana) possivelmente foram perdidas amostras com picos de estradiol e/ou progesterona. De acordo com essas características semelhantes entre a maioria das fêmeas do estudo, podemos sugerir que a raposa-do-campo seja poliéstrica sazonal, com atividade ovariana ocorrendo principalmente nos meses de julho, agosto e setembro.

Esse resultado indica que a raposa-do-campo possui um ciclo reprodutivo diferente da literatura existente que a classifica como monoestrica anual (DALPONTE, 2003). O que também a difere das duas outras espécies do mesmo gênero, a Lycalopex gymnocercus e Lycalopex culpaeus que também são classificadas como monoestricas anuais (DEMATTEO et al., 2006). 
O cahorro-do-mato (Cerdocyon thous), simpátrico da raposa-do-campo, é classificado como não sazonal, com animais possuindo apenas uma cria por ano, mas podendo ter uma segunda prenhez no ano, se ocorrer perda precoce dos filhotes ou tiver abundância de alimentos o ano todo como ocorre em cativeiro (CORREAA, 2004; DEMATTEO et al., 2006). Porém, SOUZA et al. (2012), demonstrou através das dosagens de metabólitos fecais que a espécie possui estro anual com período reprodutivo entre junho e setembro.

O lobo-guará (Chrysocyon brachyururs), outro canídeo simpátrico da raposa-docampo, é uma espécie monoéstrica sazonal com período reprodutivo de 3 a 5 meses, abril a junho na América Latina e outubro a fevereiro na América do Norte (VELLOSO et al.,1998; MAIA; GOUVEIA, 2002; SONGSASEN et al., 2006).

Os resultados obtidos nesse estudo indicam que a dosagem de metabólitos fecais de progesterona e estradiol podem ser usadas para diferenciar o período reprodutivo do período não reprodutivo em fêmeas de Lycalopex vetulus, fornecendo informações importantes sobre a biologia reprodutiva da espécie, o que pode contribuir no desenvolvimento de estratégias de conservação da espécie, como por exemplo aumentar o sucesso reprodutivo ex situ. Esses resultados estão muito próximos das observações feitas em populações de vida livre dessa espécie, que relatam nascimentos apenas uma vez ao ano, com acasalamentos ocorrendo em junho, com nascimentos em agosto (DALPONTE, 2009; LEMOS et al., 2011). Fêmeas lactantes foram observadas em setembro no Mato Grosso (DALPONTE, 2003) e outubro no sul da Bahia (JUAREZ; MARINHO-FILHO, 2002).

Os principais estudos ecológicos da espécie foram realizados nos estados de Mato Grosso, Bahia e Goiás (JUAREZ; MARINHO-FILHO, 2002; DALPONTE, 2003, 2009; ROCHA, 2006; LEMOS, 2007). Todas as fêmeas do presente estudos estavam localizadas no estado de São Paulo, o que pode explicar a pequena variação de um ou dois meses nos meses de maior atividade ovariana, levando também em consideração que os outros trabalhos existentes com essa espécie foram apenas observações de populações de vida livre, não existindo qualquer avaliação fisiológica dos animais.

As fêmeas 7 e 8, que dividem um mesmo recinto no Zoológico de Ribeirão Preto, não apresentaram um padrão de ciclicidade. Apesar das dosagens dos metabólitos fecais de progesterona e estradiol desses indivíduos em vários momentos ultrapassarem os valores considerados basais para cada indivíduo, não foram suficientemente altos para serem caracterizados como picos, o que poderia sinalizar teoricamente uma maior atividade de maturação folicular ou ciclicidade dessas fêmeas. 
Dentre as possíveis causas para esses indivíduos não apresentarem sinais de ciclicidade, temos o acometimento desses dois indivíduos por alguma enfermidade reprodutiva, como por exemplo a presença de cistos ovarianos ou tumores (MACLACHLAN, 1987; BLENDINGER, 2007). Os animais participantes do projeto não passaram por uma avaliação reprodutiva prévia ou posterior as coletas de amostras então não é possível saber se elas possuíam algum acometimento reprodutivo.

Uma outra hipótese é o acometimento desses indivíduos pelo estresse crônico. Esses são os únicos indivíduos que não estão em exposição ao público, estão em um recinto improvisado na área interna do parque a mais de dois anos. Devido a esse longo período sob as mesmas condições, os animais poderiam já não mais apresentar características de um estresse agudo, com altas dosagens de glicocorticóides, mas sim um estresse crônico (NELSON, 2005; DICKENS; ROMERO, 2013). Este cenário corresponde com as dosagens obtidas ao longo dos 12 meses, onde as médias mensais da dosagem de glicocorticóides desses indivíduos não são mais altas do que as médias dos outros indivíduos do projeto.

Outra possível hipótese, poderia ser o efeito macho. A fêmea 7 possui três anos e a fêmea 8 dois anos de idade. As duas chegaram filhotes ao cativeiro e nunca tiveram contato com um macho de raposa-do-campo. Em algumas espécies, para que a fêmea entre na puberdade e inicie sua atividade reprodutiva é necessária a presença do macho (WIDOWSKI et al., 1992). Após o início, ao longo da vida reprodutiva a fêmea não precisa necessariamente do macho para manter sua ciclicidade, mas sua presença é importante para o "start". Esse efeito é verificado nos saguis Sanguinus oedipus (WIDOWSKI et al., 1992). Em ratos, a presença no macho adulto induz a puberdade precoce nas fêmeas (BRONSON; MARUNIAK, 1975). As fêmeas de cachorro vinagre (Speothos venaticus) não necessitam do macho para iniciar o estro, mas a presença do macho diminui significativamente o intervalo entre estros (DEMATTEO et al., 2006).

\subsubsection{Concentrações de Glicocorticóides}

No presente estudo o perfil de eliminação dos metabólitos fecais de glicocorticóides segue o mesmo perfil de eliminação dos metabolitos fecais de estradiol e progesterona, o que é esperado do ponto de vista biológico. No período de maior atividade reprodutiva o animal 
também possui uma produção maior de glicocorticóides. Esse aumento ocorre, tanto nas fêmeas que estão alojadas com macho, como nas que estão sozinhas e nas que estão com outra fêmea no recinto. Como esses animais estão cativos, podemos atribuir esse aumento a uma variação sazonal fisiológica, sem contar com aumento do número de estressores ambientais, que poderia variar em um animal de vida livre, como por exemplo, disponibilidade de alimento e maior competição intra e interespecífica no período reprodutivo.

Existem vários estudos que avaliam a interação entre os glicocorticóides e o sistema gonadal. A pesar da função mais conhecida dos glicocorticóides ser de inibir a liberação de hormônios gonadais (SAPOLSKY et al., 2000), a administração de testosterona exógena demonstrou aumentar a concentração de glicocorticóides em aves de vida livre (KETTERSON et al., 1991; SCHOECH et al., 1999). Isso sugere uma complexa interação entre os sistemas gonadal e adrenal, com os glicocorticoides regulando negativamente a liberação andrógenos e concomitantemente os andrógenos aumentando a liberação de glicocorticóides. Os hormônios gonadais podem ser potencialmente um importante regulador fisiológico das mudanças sazonais na concentração de glicocorticóides (ROMERO, 2002).

Estudos indicam que algumas espécies de anfíbios, répteis, aves e mamíferos de vida livre modulam sazonalmente a liberação de glicocorticóides (ROMERO, 2002). Os fatores que induzem essas mudanças sazonais (fotoperíodo, temperatura, disponibilidade de alimento) ainda é desconhecido, porém existem algumas hipóteses.

A hipótese da mobilização de energia coloca que a concentração de glicocorticóides vai ser maior durante períodos energeticamente mais custosos do ano. Assim, o aumento da concentração de glicocorticóides durante a estação reprodutiva seria resultado da maior demanda energética nesse período, comparado ao restante do ano. Essa hipótese pode ser válida para fêmeas, que na maioria das espécies utilizam a maior parte da sua demanda energética para criar a próxima geração. Também pode ser válida para machos de várias espécies, já que a reprodução frequentemente aumenta o custo energético associado a testosterona (KETTERSON; NOLAN, 1999) e a defesa territorial.

Outra hipótese é a do comportamento, onde as variações anuais da concentrações de glicocorticóides resultariam dos animais terem diferentes requerimentos para expressar (ou não expressar) os comportamentos mediados por glicocorticóides em diferentes épocas do ano. 
A terceira é a hipótese preparatória, onde o aumento da frequência de eventos adversos (ex. estressores) poderia resultar em uma maior concentração basal de glicocorticóides. A análise do risco de predação, risco de injurias derivadas de competições intraespecíficas e riscos de doenças durante diferentes estágios sazonais de uma espécie deve se relacionar com a concentração basal de glicocorticóides. É importante ressaltar que essa hipótese não requere que o indivíduo seja submetido a mais estressores em certas épocas do ano, apenas que a chance de ser submetido a estressores seja mais provável (ROMERO, 2002).

Apesar de existirem hipóteses, ainda não existem estudos que comprovem que os níveis de glicocorticóides podem ser diretamente influenciados pelos hormônios reprodutivos ou até mesmo pelo fotoperíodo, nem estudos que descrevam a via pelo qual os níveis de glicocorticóides podem ser afetados pela sazonalidade. O estudo desses temas é de grande importância para o melhor entendimento da função dos hormônios glicocorticóides sobre os animais.

O cativeiro prolongado pode resultar em profundas e imprevisíveis mudanças na função do eixo Hipotalâmico-Pituitário-Adrenal (ROMERO; WINGFIELD, 1999), dificultando ou impossibilitando a verificação das variações anuais naturais nessas populações (ROMERO, 2002). Apesar dessa problemática com o cativeiro, o presente estudo conseguiu registar essa variação sazonal nas fêmeas de raposa-do-campo em cativeiro, nas diferentes instituições mantenedoras dos animais

Os resultados ainda demonstram que além da grande quantidade de estressores que podem alterar a excreção dos glicocorticóides de um indivíduo, deve-se também considerar a flutuação sazonal e o status reprodutivo do animal que podem afetar as concentrações fecais de metabólitos de glicocorticóides.

Portanto, através dos resultados do presente estudo, explicitando as variações sazonais e coincidentes com o período reprodutivo, é importante ressaltar que altos níveis de glicocorticóides não devem sempre ser considerados prejudiciais. A avaliação dos níveis de glicocorticóides deve ser feita com muito critério, preferencialmente sempre associada a outras avaliações, como hormônios reprodutivos, e variações comportamentais e ecológicas, pois os glicocorticóides não estão relacionados apenas ao estresse, mas também com diversas variações no metabolismo energético. 
A elaboração de estudos coerentes e de conclusões abrangentes sobre esse tema é importante pois a medicina da conservação busca estudar a dinâmica entre animais, humanos e meio ambiente e dados científicos são necessários para mensurar o impacto da ação humana na vida selvagem (KEAY et al., 2006). Métodos não invasivos para quantificar hormônios reprodutivos e glicocorticóides em amostras fecais são ferramentas importantes em estudos in situ e ex situ, que nos permite obter dados ecológicos e fisiológicos, e a combinação dessas informações vai fornecer a base para a elaboração de programas de conservação mais efetivos (WIKELSKI; COOKE, 2006; BARJA et al., 2008).

\subsection{ESTUDOS FUTUROS}

A partir deste estudo podemos compreender melhor a fisiologia reprodutiva da raposado-campo (Lycalopex vetulus) e através da padronização de conhecimentos básicos e da validação da técnica é possível, e necessário, o desenvolvimento de novas pesquisas para aumentar nosso conhecimento com relação à espécie. A seguir serão sugeridas novas linhas de pesquisa que seriam interessantes de ser desenvolvidas.

- Monitoramento hormonal não invasivo de fêmeas de Lycalopex vetulus in situ, confirmando ou não o mesmo perfil de excreção dos hormônios reprodutivos, com mais ênfase no período pressuposto de maior atividade reprodutiva para poder determinar a duração de cada fase reprodutiva.

- Correlação do perfil hormonal dos animais in situ, com alterações comportamentais e com as fases ecológicas que o animal passa ao longo de um ano (acasalamento, gestação, criação dos filhotes, puberdade e dispersão).

- Avaliação da excreção de testosterona nos machos ao longo do ano para avaliar uma possível maior atividade reprodutiva em determinada época do ano.

- Desenvolvimento de técnicas de reprodução assistida como coleta de sêmen e inseminação artificial. 


\subsection{COMENTÁRIOS FINAIS}

\subsubsection{Recintos e Alimentação da Raposa-do-campo em Cativeiro}

A Instrução Normativa 04 de 04 de março de 2002 do IBAMA dispõe no artigo 23 sobre as recomendações para recintos de mamíferos. Os recintos do gênero Lycalopex precisam possuir ao menos $20 \mathrm{~m}^{2}$, cambiamento de $2 \mathrm{~m}^{2}$, maternidade de $1 \mathrm{~m}^{2}$, piso de terra e segurança nível II, onde deve-se prender o animal para o tratador entrar no recinto.

Os recintos de raposa-do-campo das instituições participantes do presente projeto, possuem ao menos as especificações mencionadas a cima, exceto no Bosque e Zoológico Municipal Dr. Fábio de Sá Barreto em Ribeirão Preto - SP, onde os animais não possuem ainda um recinto de exposição, e estão alojadas temporariamente na área interna do parque, na área de quarentena. Dois indivíduos dividem um recinto de cerca de $10 \mathrm{~m}^{2}$, sem cambiamento e sem piso de terra.

A legislação sobre o tamanho e disposição de recintos para animais selvagens em cativeiro, é limitada, e determina um padrão mínimo a seguir. Para uma espécie chegar a reproduzir em cativeiro, muitas vezes o mínimo não basta, é preciso ter mais elementos dentro do recinto para que os animais possam reproduzir e os elementos variam para cada espécie.

A raposinha utiliza tocas de tatu, para parir e cuidar dos filhotes nos primeiros meses de vida (DALPONTE; COURTENAY, 2004). Mesmo antes do acasalamento, no início da atividade reprodutiva, as fêmeas e machos começam a preparar a toca para receber os filhotes.

Uma fêmea do Zoológico Municipal Quinzinho de Barros em Sorocaba, chegou a parir 4 filhotes em outubro de 2012, apesar da terra compactada, ela cavou um buraco no recinto e teve seus filhotes dentro da toca. Isso demonstra que além do espaço e alimentação adequados, é importante para a reprodução da raposa-do-campo, a existência de tocas no recinto, já que na natureza ela apenas adequa tocas prontas de tatu para sua reprodução. Seria necessário ao menos ter a existência de um piso adequado para que ela possa cavar a toca, pois mesmo que a maioria das instituições possua recinto de terra, a compactação é grande dificultando a fabricação das tocas.

A alimentação fornecida a raposa-do-campo, em todas as instituições que participaram 
da pesquisa é bem semelhante entre si e muito parecida com a alimentação de outro canídeo brasileiro, o cachorro-do-mato (Cerdocyon thous), variando apenas a quantidade em algumas instituições.

Apesar do tamanho similar e serem taxonomicamente próximos, o cachorro-do-mato e a raposinha apresentam uma baixa sobreposição em seus itens alimentares em vida livre. Embora ambos sejam onívoros a alimentação da L. vetulus em vida livre é composta basicamente de cupins e outros artrópodes, frutos e pequenos vertebrados em menor quantidade (DALPONTE; COURTENAY, 2004).

Existem muitos estudos a cerca da dieta de animais de zoológicos, mas especificamente para Lycalopex vetulus, poucas informações estão disponíveis sobre suas necessidades diárias em termos de calorias, nutrientes e minerais, necessitando de mais estudos nesse tópico para que possamos alimentar os animais cativos dessa espécie mais adequadamente.

\subsubsection{Conservação de Espécies e o Papel dos Zoológicos}

Há muitos anos já não é mais aceito que um zoológico sirva apenas como expositor de animais, o papel na sociedade atual de um zoológico moderno é muito mais complexo e importante, baseado em três pilares fundamentais: educação, pesquisa e entretenimento.

A Associação de Zoológicos Americanos (AZA) acredita que o manejo animal, criação, cuidados veterinários e as práticas de conservação devem ser baseadas em ciência, e o compromisso com a pesquisa científica, básica e aplicada, é uma marca essencial do zoológicos e aquários modernos. As instituições acreditadas pela AZA devem conduzir ou facilitar pesquisas, tanto in situ quanto ex situ, para avançar o conhecimento cientifico dos animais sob seus cuidados e promover a conservação de populações selvagens (AZA, 2014).

Apesar de há mais de 30 anos esses conceitos dos zoológicos modernos existirem e serem aplicados nos principais zoológicos do mundo, os zoológicos brasileiros ainda estão muito abaixo desses conceitos e são poucas as instituições que atuam como centros de pesquisa, conservação, educação ambiental e lazer. 
De acordo com o último levantamento feito pela Sociedade Brasileira de Zoológicos (SZB) em 2013, o Brasil possui 110 zoológicos e 13 aquários. Desses, 31 são particulares, 73 municipais ou estaduais. Em sua grande maioria, as instituições não cobram entrada, ou cobram um valor simbólico, o que limita a obtenção de recursos para investir na educação e pesquisa.

Porém, o problema pode ser mais profundo que falta de recurso financeiro para investir em pesquisa e conservação. Embora haja profissionais comprometidos como os que gentilmente contribuíram para o presente projeto, acredito que falta mais incentivo e envolvimento de parte dos técnicos das instituições para poder efetivamente contribuir com pesquisas e para a conservação de espécies de forma geral.

A raposa-do-campo é o único canídeo que ocorre apenas no território brasileiro. $\mathrm{O}$ desconhecimento a cerca da espécie e o número de indivíduos da espécie encontrado em cativeiro é preocupante do ponto de vista da conservação, quando pensamos que uma das funções do cativeiro é manter uma população viável para futuros planos de ação.

Não existe ainda qualquer plano de manejo com os animais em cativeiro mesmo nas instituições paulistas, onde a raposa-do-campo é classificada como ameaçada de extinção. Seria extremamente valioso realizar um plano de manejo da raposa-do-campo, considerando todos os animais cativos como parte de uma única metapopulação, garantindo assim que os indivíduos em cativeiro representem uma população viável a longo prazo ex situ.

O Brasil não pode ficar a margem dos conceitos mundiais sobre zoológicos e aquários, e a sociedade brasileira deve cobrar cada vez mais que nossas instituições assimilem esses conceitos. Não basta apenas possuir um recinto bonito para exibir os animais, mas que o animal que está ali cativo, sirva como um fonte de educação, pesquisa e conservação. É fundamental que os zoológicos continuem a se adaptar e se desenvolver em todos os setores ou correm o risco de regredir e se tornar extintos. 


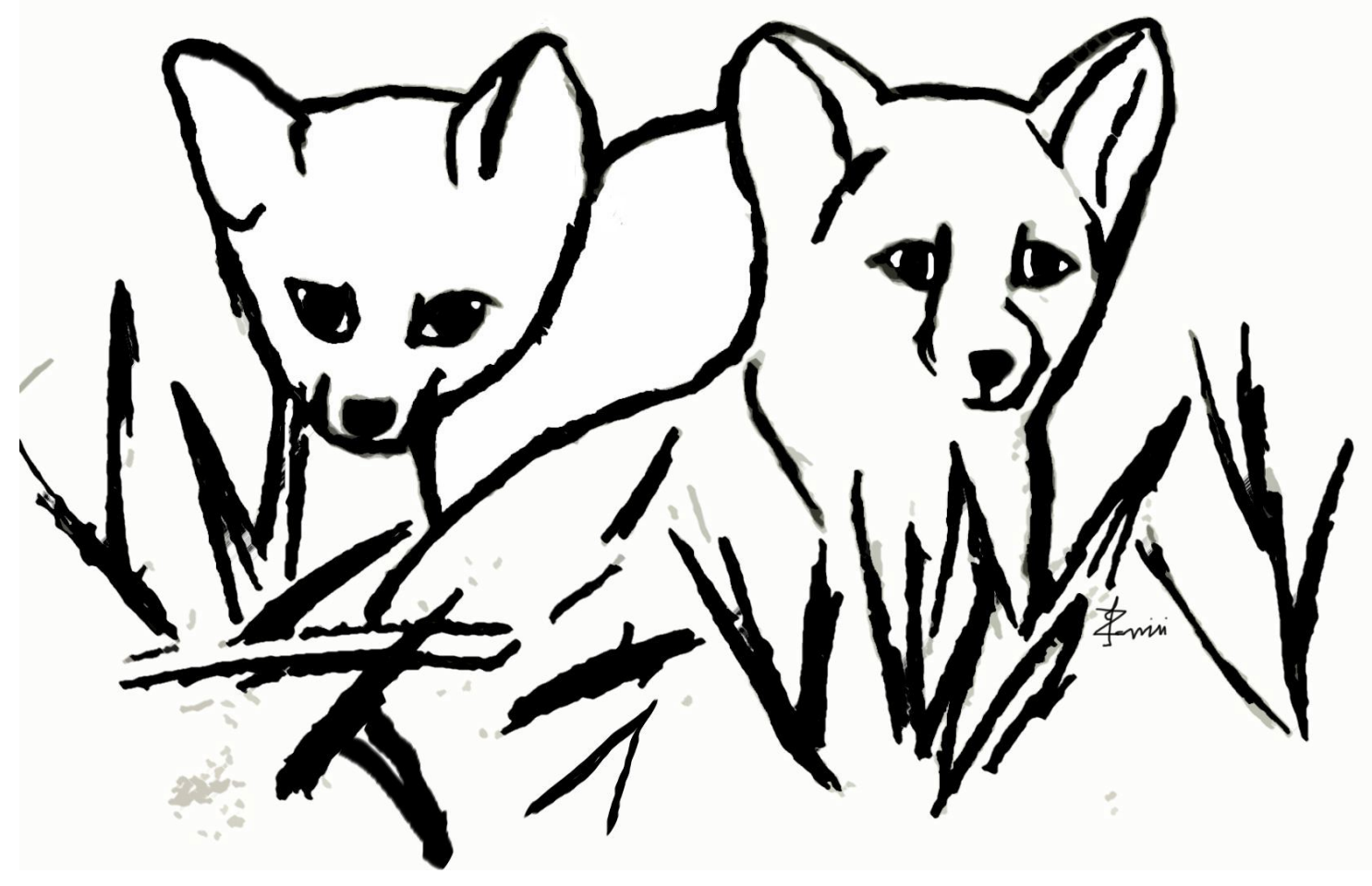

Conctusão 


\section{CONCLUSÃO}

- A validação com análogo de GnRH mostrou o perfil de resposta esperado, validando assim, do pondo de vista fisiológico, os ensaios utilizados para dosagens dos metabólitos fecais de progesterona e estradiol.

- Foi possível realizar uma avaliação longitudinal e não invasiva da função reprodutiva de Lycalopex vetulus, mantidos em cativeiro, relacionada a atividade ovariana, através da extração e quantificação dos metabólitos fecais de progesterona e estradiol.

- Mesmo em diferentes condições de cativeiro (solitária, casal, duas fêmeas juntas), o perfil de excreção dos metabólitos fecais de progesterona e estradiol foi o mesmo em 6 das 8 fêmeas do estudo, sendo que duas fêmeas não apresentaram atividade cíclica ovariana no período do estudo.

- As concentrações dos metabólitos fecais de progesterona e estradiol apresentaram diferenças significativas nos meses de julho, agosto e setembro, com concentrações mais altas dos dois hormônios do que nos outros 9 meses do ano.

- O perfil de excreção dos metabólitos fecais de glicocorticóides seguiu o mesmo perfil de excreção dos metabólitos fecais de progesterona e estradiol para as fêmeas cíclicas.

- Os resultados obtidos correspondem com o observado em populações de raposa-docampo de vida livre, onde os nascimentos ocorrem apenas uma vez ao ano com acasalamento sendo observado em junho e julho.

- Podemos sugerir que a raposa-do-campo seja poliéstrica sazonal com atividade reprodutiva no inverno. 


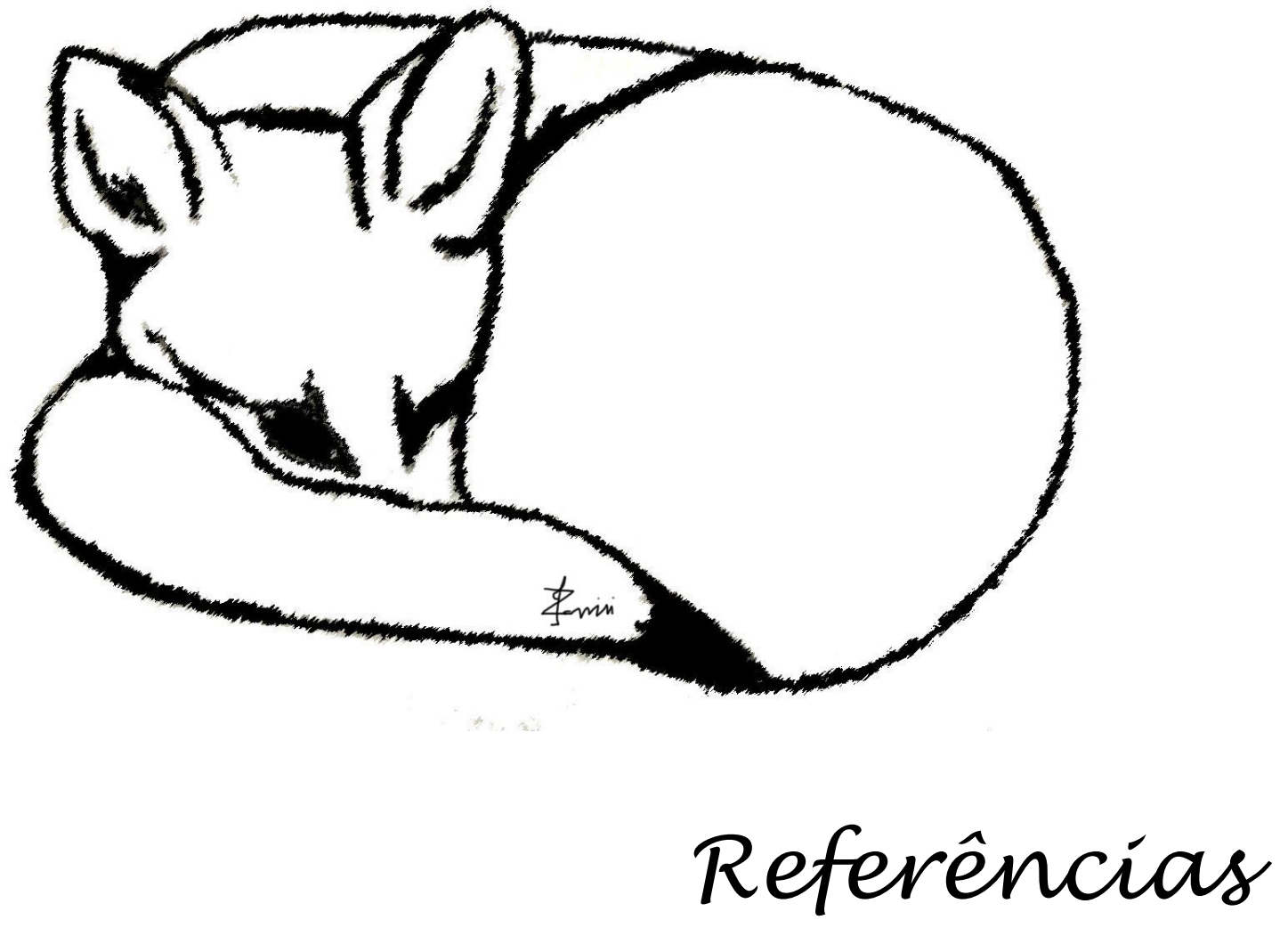




\section{REFERÊNCIAS}

AZA. Association of Zoos \& Aquariums, 2014. Disponível em: $<$ https://www.aza.org/research>. Acesso em: 15 jun. 2014.

BARJA, I.; SILVÁN, G.; ILLERA, J. C. Relationships between sex and stress hormone levels in feces and marking behavior in a wild population of iberian wolves (Canis lupus signatus). Jounal of Chemical Ecology, v. 34, p. 697-701, 2008.

BLENDINGER, K. Physiology and pathology of the estrous cycle of the bitch. In: ITALIAN COMPANION ANIMAL VETERINARY ASSOCIATION CONGRESS, 2007, Rimini, Italia. Proceedings... Rimini: SCIVAC, 2007.

BRASIL. Instituto Brasileiro do Meio Ambiente e dos Recursos Naturais Renováveis. Instrução Normativa n.04, de 04 de março de 2002. Diário Oficial da União, Brasília, DF, 2002.

BRAVERMAN, I. Conservation without nature: the trouble with in situ versus ex situ conservation. Geoforum, v. 51, p. 47-57, 2014.

BREUNER, C. W.; WINGFIELD, J. C.; ROMERO, L. M. Diel rhythms of basal and stressinduced corticosterone in wild, seasonal vertebrate, gambel's white-crowned sparrow.

Journal of Experimental Zoology, v. 284, p. 334-342, 1999.

BRONSON, F. H.; MARUNIAK, J. A. Male-induced puberty in female mice: evidence for a synergistic action of social cues. Biology of Reproduction, v. 13, p. 94-98, 1975.

BROWN, J. L.; WASSER, S. K.; WILDT, D. E.; GRAHAM. L. H. Comparative aspects of steroid hormone metabolism and ovarian activity in felids, measured noninvasively in feces. Biology of Reproduction, v. 51, p. 776-786, 1994.

BROWN, J. L. Wildlife endocrinology manual. Front Royal, VA : CRC Endocrine Research Laboratory, National Zoological Park - Conservation and Research Center, 2008.

BROWN, J. L.; TERIO, K. A.; GRAHAM, L. H. Fecal androgen metabolite analysis for non invasive monitoring of testicular steroidogenic activity in felids. Zoo Biology, n. 15, p. 425434, 1996.

BROWN, J.L.; WILDT, D. Assessing reproductive status in wild felids by non-invasive fecal steroid monitoring. International Zoo, v. 35, p. 173-191, 1997.

BUSCH, D. S.; HAYWARD, L. S. Stress in a conservation context: A discussion of glucocorticoid actions and how levels change with conservation-relevant variables. Biological Conservation, v. 142, p. 2844-2853, 2009.

BUTCHART, S. H. M.; WALPOLE, M.; COLLEN, B.; VAN STRIEN, A.; SCHARLEMANN, J. P. W. Global biodiversity: indicators of recent declines. Science, v. 328, p. 1164-1168, 2010. 
BYERS, O.; LEES, C.; WILCKEN, J.; SCHWITZER, C. The One Plan approach: the philosophy and implementation of CBSG's approach to integrated species conservation planning. WAZA Magazine, v. 14, p. 2-5, 2013.

CAVALCANTI, R. B. AND JOLY, C. A. Biodiversity and conservation priorities in the cerrado region. In: OLIVEIRA, P. S.; MARQUIS, R. J. (Eds). The cerrados of Brazil. ecology and natural history of a neotropical savanna. New York: Columbia University Press, 2002. p. 351-367.

CONDE, D. A.; FLESNESS, N.; COLCHERO, F.; JONES, O. R.; SCHEUERLEIN, A. An emerging role of zoos to conserve biodiversity. Science, v. 331, p. 1390-1391, 2011a.

CONDE, D. A.; FLESNESS, N.; COLCHERO, F.; JONES, O. R.; SCHEUERLEIN, A. Zoos and captive breeding response. Science, v. 332, p. 1150-1151, $2011 \mathrm{~b}$.

CONDE, D. A.; COLCHERO, F.; GUSSET, M.; PEARCE-KELLY, P.; BYERS, O.;

FLESNESS, N.; BROWNE, R. K.; JONES, O. R. Zoos through the lens of the IUCN red list: A global metapopulation approach to support conservation breeding programs. Plos One, v.

8, n. 12, p. 1-9, 2013.

CORREAA, M. F. Ecologia de graxains (carnívora: canidade; Cerdocyon thous e Pseudalopex gymnocercus) em um remanescente de mata atlântica na região metropolitana de Porto Alegre - Parque estadual de Itapuã - Rio Grande do Sul, Brasil. 2004. 108 p. Dissertação (Mestrado em Ecologia) - Universidade Federal do Rio Grande do Sul, Porto Alegre, 2004.

COURTENAY, O.; MACDONALD, D. W.; GILLINGHAM, S.; ALMEIDA, G.; DIAS, R. First observations on South America's largely insectivorous canid: the hoary fox (Pseudalopex vetulus). Journal of Zoology, v. 268, n. 1, p. 45-54, 2006.

DALPONTE, J. C. The hoary fox in Brazil. Canid News, v. 3, p. 23-24, 1995.

DALPONTE, J. C. História natural, comportamento e conservação da raposa- do-campo, Pseudalopex vetulus (Canidae). 2003. 179 p. Tese (Doutorado em Biologia Animal) Universidade de Brasília, Brasília, 2003.

DALPONTE, J. C. Lycalopex vetulus (Carnivora: Canidae). Mammalogy, v. 847, p. 1-7, 2009.

DALPONTE, J. C.; COURTENAY, O. Hoary fox Pseudalopex vetulus (Lund, 1842). In: SILLERO-ZUBIRI, C.; HOFFMANN, M.; MACDONALD, D. W. (Eds.). Canids: foxes, wolves, jackals and dogs. status survey and conservation action plan. Gland, Switzerland and Cambridge, UK: IUCN/SSC Canid Specialist Group, 2004. p. 72- 76.

DAVIDSON, A. P.; FELDMAN, E. C. Alterações ovariana e do ciclo estral. In: ETTINGER, S. J.; FELDMAN, E. C. Tratado de medicina interna veterinária - doenças do cão e do gato. 5. ed., Rio de Janeiro: Guanabara Koogan, 2004. cap. 158, p. 1602-1609. 
DEMATTEO, K. E.; PORTON, I. J.; KLEINAN, D. G.; ASA, C. S. The effect of the male bush dog (Speothos venaticus) on the female reproductive cycle. Journal of Mammalogy, v. 87, n. 4, p. 723-732, 2006.

DICKENS, M. J.; ROMERO, L. M. A consensus profile for chronically stressed wild animals does not exist. General and Comparative Endocrinology, v. 191, p. 177-189, 2013.

EAZA. European Association of Zoos and Aquaria: Strategy 2009-2012. Disponível em: $<$ http://www.eaza.net/about/Pages/Introduction.aspx>. Acesso em: 10 jun. 2014.

GALETTI, M.; EIZIRIK, E.; BEISIEGEL, B.; FERRAZ, K.; CAVALCANTI, S.; SRBEKARAUJO, A. C.; CRAWSHAW, P.; PAVIOLO, A.; GALETTI JR, P. M.; JORGE, M. L.; MARINHO-FILHO, J.; VERCILLO, U.; MORATO, R. Atlantic rainforest's jaguars in decline. Science, v. 342, n. 6161, p. 930, 2013.

GUDERMUTH, D. F.; CONCANNON, P. W.; DAELS, P. F.; LASLEY, B. L. Pregnancyspecific elevations in fecal concentrations of estradiol, testosterone and progesterone in the domestic dog (Canis familiaris). Theriogenology, v. 50, p. 237-248, 1998.

GUIMARÃES, M. A. B. V.; OLIVEIRA, C. A.; RIBEIRO, E. A. A. Monitoring ovarian function in the capuchin monkey (Cebus apella) using fecal and urinary hormone analyses. In: THE SECOND INTERNATIONAL SYMPOSIUM ON ASSISTED REPRODUCTIVE TECNOLOGY FOR THE CONSERVATION AND GENETIC MANAGEMENT OF WILDLIFE, 2002, Omaha. Proceedings... Omaha: ART, 2002. p. 290.

GUSSET, M.; DICK, G. "Building a future for wildlife?" Evaluating the contribution of the world zoo and aquarium community to in situ conservation. Intenational Zoo Yearbook, v. 44, p. 183-191, 2010.

HOLDO, R. M.; SINCLAIR, A. R. E.; DOBSON, A. P.; METZGER, K. L.; BOLKER, B. M.; RITCHIE, M. E.; HOLT, R. D. A Disease-Mediated Trophic Cascade in the Serengeti and its Implications for Ecosystem C. Plos Biology, v.7, 2009.

IUCN. International Union for Conservation of Nature, 2014. Disponível em: $<$ http://www.iucn.org>. Acesso em: 20 jun. 2014.

JÁCOMO, A. T. A.; SILVEIRA, L.; DINIZ-FILHO, J. A. F. Niche separation between the maned wolf (Chrysocyon brachyurus), the crab-eating fox (Dusicyon thous) and the hoary fox (Dusicyon vetulus) in central Brazil. Journal of Zoology, v. 262, n. 1, p. 99- 106, 2004.

JOHNSON, A. E. M. The development of assisted reproductive techniques for managing maned wolves (Chrysocyon brachyurus) ex situ. 2012. $116 \mathrm{f}$. Thesis (Master of Science) Fairfax, VA : George Mason University, 2012.

JOHNSON, A. E. M.; FREEMAN, E. W.; COLGIN, M.; MCDONOUGH, C.; SONGSASEN, N. Induction of ovarian activity and ovulation in an induced ovulator, the maned Wolf (Chrysocyon brachyurus), using GnRH agonist and recombinant LH.

Theriogenology, v. 82, p. 71-79, 2014. 
JUAREZ, K. M.; MARINHO-FILHO, J. Diet, habitat use, and home ranges of sympatric canids in Central Brazil. Journal of Mammalogy, v. 83, n. 4, p. 925-933, 2002.

KEAY, J. M.; SINGH, J.; GAUNT, M. C.; KAUR, T. K. Fecal glucocorticoids and their metabolites as indicators of stress in various mammalian species: A literature review. Journal of Zoo and Widlife Medicine, v. 37, n. 3, p. 234-244, 2006.

KELLY, J. D. Effective conservation in the twenty-first century: the need to be more than a zoo. One organization's approach. International Zoo Yearbook, v. 35, n. 1, p. 1-14, 1997.

KETTERSON, E. D.; NOLAN Jr., V.; WOLF, L.; ZIEGENFUS, C.; DUFTY Jr.; A. M.; BALL, G. F.; JOHNSEN, T. Testosterone and avian life histories: the effect of experimentally elevated testosterone on corticosterona and body mass in dark-eyed juncos. Hormone Behavior, v. 25, p. 489-503, 1991.

KETTERSON, E. D.; NOLAN Jr., V. Adaptation, exaptation, and constraint: a hormonal perspective. The American Naturalist, v. 154, p. 4-25, 1999.

LANDYS, M. N.; RAMENOFSKY, M.; WINGFIELD, J. C. Actions of glucocorticoids at seasonal baseline as compared to stress-related levels in the regulation of periodic life processes. General and Comparative Endocrinology, v. 148, p. 132-149, 2006.

LEMOS, F. G. Ecologia e comportamento da raposa-do-campo Pseudalopex vetulus e do cachorro-do-mato Cerdocyon thous em áreas de fazendas no bioma cerrado. 2007. $62 \mathrm{f}$. Dissertação (Mestrado em Ciências) - Universidade Federal de Uberlândia, Uberlândia, 2007.

LEMOS, F. G.; AZEVEDO, F. C. Lycalopex vetulus (Lund, 1842) Carnivora, Canidae In: BRESSAN, P. M.; KEIRULFF, M. C. M.; SUGIEDA, A. M. Fauna ameaçada de extinção no Estado de São Paulo: vertebrados. São Paulo: Fundação Parque Zoológico de São Paulo: Secretaria do Meio Ambiente, 2009. p. 61.

LEMOS, F. G.; AZEVEDO, F. C.; COSTA, H. C. M.; MAY JUNIOR, J. A. Human threats to hoary and crab-eating foxes in central Brazil. Canid News, v. 14, 2011.

LEMOS, F. G.; FACURE, K. G. Seasonal variation in foraging group size of crab-eating foxes in the cerrado biome, central Brazil. Mastozoologia Neotropical, v. 18, p. 239-245, 2011.

LEVI, T.; KILPATRICK, A. M.; MANGEL, M.; WILMERS, C. C. Deer, predators, and the emergence of Lyme disease. Proceedings of the National Academy of Science of United States of America, v. 109, n. 27, p. 10942-10947, 2012.

MACLACHLAN, N. J. Ovarian disorders in domestic animals. Environmental Health Perspectives, v. 73, p. 27-33, 1987.

MAIA, O. B.; GOUVEIA, A. M. G. Birth and mortality of maned wolves, Chrysocyon brachyurus (Illiger, 1811) in captivity. Brazilian Journal of Biology, n. 62, p. 25-32, 2002.

MYERS, N.; MITTERMEIER, C. G.; FONSECA, G. A. B.; KENT, J. Biodiversity hotspots for conservation priorities. Nature, v. 403, p. 853-858, 2000. 
NELSON, R. J. An introduction to behavioral endocrinology. 3. ed. [S. 1.]: Sinauer, 2005.

OSTFELD, R. S.; HOLT, R. D. Are predators good for your health? Evaluating evidence for top-down regulation of zoonotic disease reservoirs. Frontiers in Ecology and Environment, v. 13, p. 13-20, 2004.

PALME, R.; MOSTL, E. Measurement of cortisol metabolites in faeces of sheep as a parameter of cortisol concentration in blood. Phisiologie and Ethology of Wild and Zoo Animals, p.192-197, 1996. Proceedings Suppl. II.

PETER, A.T.; KASPUTIN N.; CRISTER J.K. Analysis of sex steroid metabolites excreted in feces and urine of nondomesticated animals. The Compedium, v. 18, n. 7, p. 781- 791, 1996.

RIPPLE, W. J.; BESCHTA, R. L. Large predators limit herbivore densities in northern forest ecosystems. European Jounal of Wildlife Research, v. 58, p. 733-742, 2012.

RIPPLE, W. J.; ESTES, J. A.; BESCHTA, R. L.; WILMERS, C. C.; RITCHIE, E. G.; HEBBLEWHITE, M.; BERGER, J.; ELMHAGEN, B.; LETNIC, M.; NELSON, M. P.; SCHMITZ, O. J.; SMITH, D. W.; WALLACH, A. D.; WIRSING, A. J. Status and ecological effects of the world's largest carnivores. Science, v. 343, p. 151-162, 2014.

ROCHA, E. C. Aspectos da história natural e conservação de Pseudalopex vetulus (LUND, 1842) (Carnivora: Canidae). 2006. 67 f. Dissertação (Mestrado em Ciências) Universidade Federal de Viçosa, Minas Gerais, 2006.

ROMERO, L. M. Seasonal changes in plasma glucocorticoid concentrations in free-living vertebrates. General and Comparative Endocrinology, v. 128, p. 1-24, 2002.

ROMERO, L. M.; STROCHLIC, D.; WINGFIELD, J. C. Corticosterone inhibits feather growth: potential mechanism explaining seasonal down regulation of corticosterone during molt. Comparative Biochemistry and Physiology, v. 142, p. 65-73, 2005.

ROMERO, L. M.; WINGFIELD, J. C. Alterations in hypothalamic-pituitary-adrenal function associated with captivity in Gambel's white-crowned sparrows (Zonotrichia leucophrys gambeleii). Comparative Biochemistry and Physiology, v. 122, p. 13-20, 1999.

SÃO PAULO (Estado). Decreto n. 60.133, de 7 de fevereiro de 2014. Diário Oficial, São Paulo, SP, caderno 1, p. 25, 2014.

SAPOLSKY, R. M.; ROMERO, L. M.; MUNCK, A. V. How do glucocorticoids influence stress-responses? Integrating permissive, suppressive, stimulatory, and adaptive actions. Endocrinology, v. 21, p. 55-89, 2000.

SCHMITZ, O. J.; RAYMOND, P. A.; ESTES, J. A.; KURZ, W. A.; HOLTGRIEVE, G. W.; RITCHIE, M. E.; SCHINDLER, D. E.; SPIVAK, A. C.; WILSON, R. W.; BRADFORD, M. A.; CHRISTENSEN, V.; DEEGAN, L.; SMETACEK, V.; VANNI, M. J.; WILMERS, C. C. Animating the Carbon Cycle. Ecosystems, v. 17, p. 344- 359, 2013. 
SCHOECH, S. J.; KETTERSON, E. D.; NOLAN, V. Exogenous testosterone and the adrenocortical response in dark-eyed juncos. The AUK, v. 116, p. 64-72, 1999.

SCHWARZENBERGER, F.; MÖSTL, E.; PALME, R. Faecal steroid analysis for noninvasive monitoring of reproductive status in farm, wild and zoo animals. Animal Reproduction Science, v. 42, p. 515-526, 1996.

SERGER, P. L. Pathways to pregnancy and parturition. 2. ed. [S. 1.]: Current conceptions, 2005.

SONGSASSEN, N.; RODDEN, M.; BROWN, J.L.; WILDT, D. E. Patterns of fecal gonadal hormone metabolites in the maned Wolf (Chrysocyon brachyurus). Theriogenology, n. 66, p. 1743-1750, 2006.

SOUZA, N. P.; FURTADO, P. V.; PAZ, R. C. R. Non-invasive monitoring of the estrous cycle in the captive crab-eating foxes (Cerdocyon thous). Theriogenology, n. 77, p. 233-239, 2012.

VELLOSO, A. L.; WASSER, S. K.; MONFORT, S. L.; DIETZ, J. M. Longitudinal fecal steroid excretion in Maned wolves (Chrysocyon brachyurus). General and Comparative Endocrinology, v. 112, p. 96-107, 1998.

WASSER, S. K.; HUNT, K. E.; BROWN, J. L.; COOPER, K.; CROCKETT, C. M.; BECHERT, U.; MILLSPAUGH, J. J.; LARSON, S.; MONFORT, S. L. A generalized fecal glucocorticoid assay for use in a diverse array of nondomestic mammalian and avian species. General and Comparative Endocrinology, v. 120, p. 260-275, 2000.

WASSER, S. K.; VELLOSO, A. L.; RODDEN, M. D. Using fecal steroids to evaluate reproductive function in female maned wolves. The Journal of Wildlife Management, v. 59, n. 4, p. 889-894, 1995.

WIDOWSKI, T. M.; PORTER, T. A.; ZIEGLER, T. E.; SNOWDON, C. T. The stimulatory effect of males on the initiation but not the maintenance of ovarian cycling in cotton-top tamarins (sanguinus oedipus). American Journal of Primatology, v. 26, p. 97-108, 1992.

WIKELSKI, M.; COOKE, S. J. Conservation physiology. Trends in Ecology and Evolution, v. 21, p. 38-46, 2006.

WILMERS, C. C.; CRABTREE, R. L.; SMITH, D. W.; MURPHY, K. M.; GETZ, W. M. Trophic facilitation by introduced top predators: Gray wolf subsidies to scavengers in Yellowstone National Park. Jounal of Animal Ecology, v. 72, p. 909-916, 2003.

WILMERS, C. C.; GETZ, W. M. Gray wolves as climate change buffers in Yellowstone. Plos Biology, v. 3, e92, 2005.

WINGFIELD, J. C. Changes in reproductive function of free-living birds in direct response to envoronmental pertubations. In: STETSON, M. H. [Ed]. Processing of Environmental Information in Vertebrates. Berlin: Springer-Verlag, 1988. p. 121-148 